$$
\begin{aligned}
& \text { UNIVERSIDADE DE SÃO PAULO } \\
& \text { INSTITUTO DE GEOCIÊNCIAS }
\end{aligned}
$$

\title{
TAXONOMIA, MODOS DE PRESERVAÇÃO E FITOGEOGRAFIA DE CONÍFERAS APTIANAS DA REGIÃO PALEOEQUATORIAL DA AMÉRICA DO SUL
}

\author{
Paula Andrea Sucerquia \\ Orientadora: Profa. Dra. Mary Elizabeth C. Bernardes-de-Oliveira
}

TESE DE DOUTORAMENTO

Programa de Pós-Graduação em Geoquímica e Geotectônica

São Paulo 
UNIVERSIDADE DE SÃO PAULO

INSTITUTO DE GEOCIÊNCIAS

\section{"TAXONOMIA, MODOS DE PRESERVAÇÃO E FITOGEOGRAFIA DE CONIFERAS APTIANAS DA REGIÃO PALEOEQUATORIAL DA AMÉRICA DO SUL"}

\section{PAULA ANDREA SUCERQUIA RENDON}

Orientador: Profa. Dra. Mary Elizabeth Cerruti Bernardes de Oliveira

TESE DE DOUTORAMENTO

COMISSÃO JULGADORA

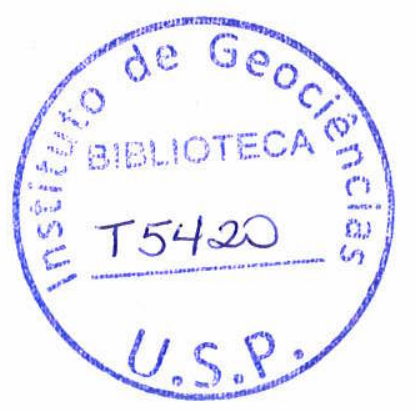

Assinatura
Nome

Presidente: Dra. Mary Elizabeth C. B. de Oliveira

Titulares: Dr. Marcello Guimaraes Simões

Dra. Tania Lindner Dutra

Dra. Georgina del Fueyo

Dra. Fresia Soledad Ricardi Torres Branco

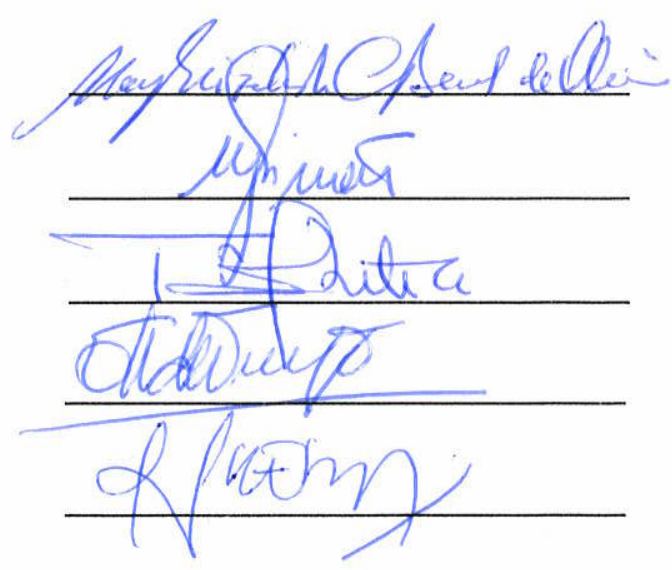




\section{UNIVERSIDADE DE SÃO PAULO \\ INSTITUTO DE GEOCIÊNCIAS}

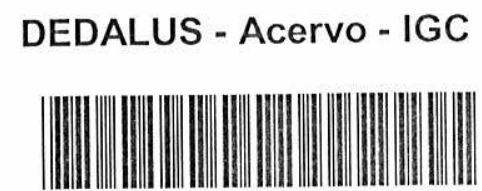

30900031785

TAXONOMIA, MODOS DE PRESERVAÇÃO E FITOGEOGRAFIA DE CONÍFERAS APTIANAS DA REGIÃO PALEOEQUATORIAL DA AMÉRICA DO SUL

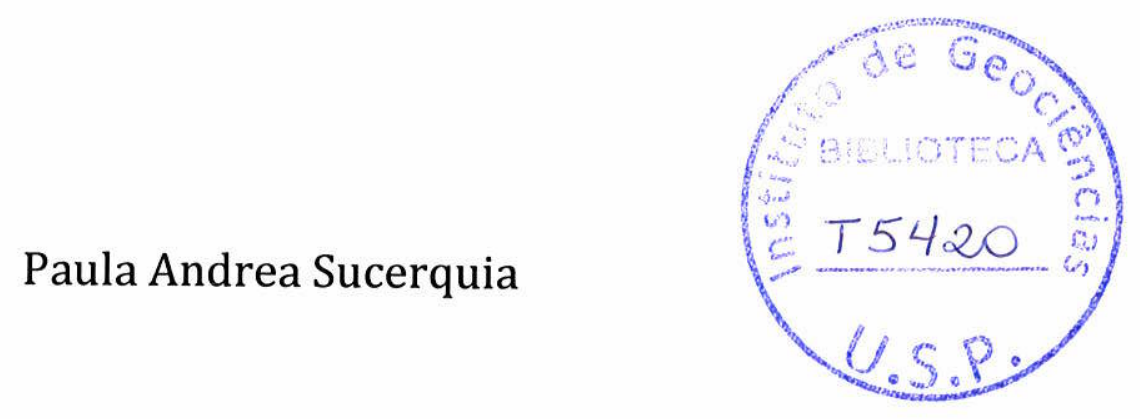

Orientadora: Profa. Dra. Mary Elizabeth C. Bernardes-de-Oliveira

TESE DE DOUTORAMENTO

Programa de Pós-Graduação em Geoquímica e Geotectônica 


\section{PAULA ANDREA SUCERQUIA}

TAXONOMIA, MODOS DE PRESERVAÇÃO E FITOGEOGRAFIA DE CONÍFERAS APTIANAS DA REGIÃO PALEOEQUATORIAL DA AMÉRICA DO SUL

Tese apresentada ao Instituto de Geociências da Universidade de São Paulo como parte das exigências para obtenção do título de Doutor em Ciências.

Área: Geotectônica

Orientadora: Profa. Dra. Mary Elizabeth C. Bernardes-de-Oliveira 
Autorizo a reprodução e divulgação total ou parcial deste trabalho, por qualquer meio convencional ou eletrônico, para fins de estudo e pesquisa, desde que citada a fonte.

Ficha catalográfica

Sucerquia, Paula Andrea.

Taxonomia, modos de preservação e fitogeografia de coníferas aptianas da região paleoequatorial da América do Sul / Paula Sucerquia - São Paulo, 2013, 86 p. 13 PRANCHAS.

Tese de doutorado apresentada ao Instituto de Geociências da Universidade de São Paulo. Área: Geotectônica Cerruti

Orientadora: Bernardes-de-Oliveira, Mary Elizabeth

1. Paleobotânica 2. Eocretáceo 3. Coníferas 4. Brasil 5. Colômbia 
Dedico esta tese a mim porque ninguém viveu, ninguém sofreu, ninguém odiou e ninguém amou ela tanto quanto eu 


\section{AGRADECIMENTOS}

Em primeiro lugar, externo meus agradecimentos às instituições que me possibilitaram realizar essa tese de doutoramento, como o Programa de Pós-graduação em Geoquímica e Geotectônica do Instituto de Geociências da Universidade de São Paulo, pela confiança em mim depositada, a oportunidade de realizar o curso de pósgraduação e de desenvolver o meu projeto de pesquisa. Em especial, agradeço ao Laboratório de Paleobotânica e Palinologia, do Departamento de Geologia Sedimentar e Ambiental, pelo material e equipamentos disponibilizados.

Agradeço, à FAPESP, Processo 2008/02884-5 que, além de garantir o meu sustento, permitiu visitas de campo e técnicas a várias instituições científicas, nacionais e estrangeiras, bem como o custeio de análises e de participação em reuniões científicas.

Entre as pessoas que me proporcionaram apoio durante o desenvolvimento desta tese, expresso meus agradecimentos:

à Profa. Dra. Mary Elizabeth Cerruti Bernardes-de-Oliveira, pela orientação, paciência, compreensão e amizade, no decorrer deste processo;

à Dra. Barbara Mohr, por seu grande estímulo, exemplo e amizade e a sua família, David, Kirsten e Annette, pela acolhida e carinho nas ocasiões em que estivemos juntos;

aos funcionários e pesquisadores do Museum für Naturkunde der HumboldtUniversität, Berlim, especialmente Kirsten Born, Christy Hipsley, Clément Coiffard, por sua ajuda e amizade durante o período de estágio nessa instituição;

ao Dr. Lutz Kunzmann, pelos conhecimentos transmitidos e estímulo ao estudo do grupo das coníferas e à sua esposa Carola, por sua doce acolhida;

ao Dr. Wolker Wilde, pela simpatia constante e apoio às minhas pesquisas;

à Dra. Gene Mapes e ao Dr. Gar Rothwell do Paleobotanical Herbarium da Ohio University (Athens, Ohio, Estados Unidos) por me permitirem o acesso a coleções, pelo treinamento em métodos de preparação de fósseis e por sua atenção e carinho por mim, durante minha estada em seu laboratório;

ao Dr Ignacio Escapa do Museo Paleontológico Egidio Feruglio, Trelew, Argentina, pelo incentivo à minha pesquisa e pelo apoio e treinamento em métodos de preparação de fósseis, bem como aos pesquisadores e técnicos do museu, pela alegria e carinho a mim dedicados;

ao Dr. Brian Axsmith da University of South Alabama (Mobile, Alabama, Estados Unidos), por me permitir acesso as suas coleções e me fornecer material para comparação;

ao John Wingerath da coleção paleobotânica do American Museum of Natural History - Smithsonian Institution (Washington D.C., Estados Unidos), pelo apoio na visita às coleções de holótipos dessa instituição;

ao Prof. Dr. Marcelo de Araújo Carvalho do Museu Nacional da Universidade Federal do Rio de Janeiro - UFRJ, pelo acesso às coleções e empréstimo de material;

ao professor Antônio Álamo da URCA - Universidade Regional do Cariri (Crato), por seu apoio nos trabalhos de campo e pelo empréstimo de material e aos seus alunos Flaviana Lima e Renan Bantim;

ao geólogo Jose Artur Ferreira Gomes de Andrade (Museu dos Fósseis do DNPM

- Departamento Nacional da Produção Mineral, do Crato, CE), que sempre me recebeu com grande simpatia, pelas visitas ao campo e por ter facilitado o acesso a espécimes de plantas fósseis bem preservados ;

ao Prof. Dr. Ismar de Souza Carvalho (Instituto de Geociências da Universidade Federal do Rio de Janeiro - UFRJ), pelo carinho e apoio em muitas fases desta pesquisa e pelo empréstimo de material para estudo; 
ao Professor Pedro Patarroyo, da Universidad Nacional de Colombia, por me permitir o acesso aos holótipos de plantas fósseis da Formação Paja, da coleção Padre Huertas;

ao próprio Padre Huertas por sua simpatia, carinho e "dicas" engraçadas de como achar fósseis;

aos meus divertidos amigos e ajudantes de campo Miguel Medina, Ricardo Barrera e Gina Zárate;

ao Centro de Imagenologia do Hospital Universitário da USP, pelo apoio na realização de análises de tomografia;

à Professora Dra. Juliana de Moraes Leme Basso, do Instituto de Geociências da Universidade de São Paulo - USP, por seu apoio, amizade e pelos conselhos para conciliar maternidade com pesquisa;

aos Professores Drs. Thomas Rich Fairchild, Wânia Duleba, Setembrino Petri, Lucelene Martins, Adriana Alves, também do IGc/USP, por estarem sempre prontos a me ajudar e aconselhar em minhas necessidades;

aos Professores Drs. Lena Monteiro e Caetano Juliani, ainda do IGc/USP, por se preocuparem com minha família e estarem sempre dispostos a nos ajudar;

aos funcionários e ex-funcionários do IGc/USP: Ana Paula, Tadeu, Isaac Sayeg, Zefinha, Henrique, Claudionor, Leonardo, Luisinho, Paulo, Renato, Flávio, Veronica, Soninha, Ritinha e Denise, Zé Carlos, Magali, Sandra, Erica, pela disponibilidade e paciência em ajudar-me em todos os momentos que precisei ao longo desses anos de convivência;

à Ivone Cardoso e aos estagiários do Laboratório de Paleontologia Sistemática do IGc/USP, pela colaboração em todos os momentos;

à Isa Mendes e à Amanda Hoelzel por se preocuparem comigo e com minha família e por todo apoio e disposição em ajudar-nos;

Aos meus amigos, colegas e ex-colegas da Pós-graduação do Instituto de Geociências: Marta Velásquez, Alejandro Salazar, Carlos Mario, Thais Hyppolito, Alex Jimenez, Veronica Ramirez, Marlei Chamani, Liza Forancelli, Ximena Villagran, Evelyn Bizan, Luana Morais, Guilherme Rafaelli, Giselle Utida, Rosana Gandini, Cláudia Tokashiki, Andreia Beleque, Nicolas Strikis, Cleyton Carneiro, pela ajuda eppppppp momentos inesquecíveis, dentro e fora do âmbito acadêmico.

À Yohana Villafañez, por sua amizade, atitude de bem com a vida e grande ajuda nos momentos finais e complicados deste processo.

Não posso deixar de mencionar minha gratidão aos que cuidaram dos meus filhos para que eu pudesse continuar com minhas pesquisas: aos avós paternos, Judith e Emilio que, inúmeras vezes, deixaram de lado suas atividades para cuidarem dos netos; ao meu pai Alfonso, à minha mãe Monica, à minha tia Martha e à minha irmã Cristina, por todo carinho demonstrado; às escolas "Lua de Algodão" e "Crecer Jugando" pelo profissionalismo e carinho com que cuidaram dos meus filhos, permitindo-me tranquilidade para trabalhar;

Aos meus filhos Emilio e Rebeca, pela paciência, embora involuntária, com que suportaram as minhas ausências e a "mamá" cansada, muitas vezes sem vontade de brincar e pelos momentos de intensa alegria e descontração que vem me brindando desde que chegaram à minha vida;

E, finalmente, agradeço ao Andres, seu companheirismo e por não me deixar desistir, por ter-me animado e ajudado nos momentos difíceis deste processo que se complicou mais do que o esperado.

Aos que me ajudaram e que tive a infelicidade de esquecer aqui, estejam certos de que foi de maneira involuntária, mas que estarão sempre presentes em minha memória. 
"The purpose of science is not to cure us of our sense of mystery and wonder, but to constantly reinvent and reinvigorate it."

Robert Sapolsky, 1998 The Trouble With Testosterone: And Other Essays On The Biology of The Human Predicament 


\section{RESUMO}

As coníferas constituem os elementos mais significativos de duas paleofloras aptianas da América do Sul: a da Formação Crato, no Brasil, e a da Formação Paja, na Colômbia. Neste trabalho, pretendeu-se encontrar algum padrão de diferenciação fitogeográfico entre elas, utilizando o grupo das coníferas como indicador de provincialismo. Para isto, em primeiro lugar, foi realizada uma avaliação taxonômica de espécimes das duas paleofloras, depositados em diferentes coleções espalhadas pelo mundo. Como a qualidade de preservação dos espécimes analisados era tão diversa, encontrando impressões, incarbonizações, petrificações, moldes internos y externos e os fósseis foram preservados em charcoal, pirita e óxidos de ferro, uma avaliação dos métodos de preparação para fitofósseis foi necessária, com o fim de encontrar o método mais informativo e menos destrutivo possível, levando em consideração que as amostras trabalhadas pertenciam ao acervo de algumas instituições. Depois de estabelecidos os métodos, na avaliação taxonômica, foram erigidas duas novas espécies para a Formação Crato: Araucaria duarteae, constituída por complexos bráctea-escama da Família Araucariaceae e Pseudofrenelopsis capillata, formada por ramos folhosos da Família Cheirolepidiaceae. Dentro desta avaliação, foram também incluídas as espécies Araucaria sp. 1 e A. sp. 2, Araucariostrobus sp. 1 e A. sp. 2 e Brachyphyllum obesum da Família Araucariaceae, na Formação Crato e Cupressinocladus lepidophylla, C. sutamarchensis, Frenelopsis sp. e Pseudofrenelopsis sp. da Família Cheirolepidiaceae e Araucaroistrobus creutzbergi, A. camargoi, A. signatus e Carpolithes sp. da Família Araucariaceae, na Formação Paja. Estas espécies tiveram suas características observadas e algumas delas como caules de aspecto suculento, folhas carnosas, estômatos afundados, cutículas espessas, papilas e pelos apontam para adaptações xeromórficas ou de halofitismo, sem que se possa estabelecer uma das duas como dominante ou exclusiva, já que as litologias associadas às paleofloras confirmam ambientes hipersalinos desenvolvidos sob climas áridos. 


\begin{abstract}
The conifers are the most significant elements of two Aptian paleofloras in South America: the Crato Formation in Brazil, and the Paja Formation in Colombia . In this study, we pretended to find some pattern of phytogeographic differentiation among them, using the group of conifers as an indicator of provincialism. For this purpose, first, it was made a taxonomic evaluation of both paleofloras, using specimens deposited in different collections around the world. As the quality of preservation of the specimens was analyzed is diverse, been found as impressions, coalifications, petrifications, external and internal casts, and fossils preserved in charcoal, pyrite and iron oxides, an evaluation of different paleobotanical methods was required, in order to find the most informative and least destructive method, considering that the specimens belonged to the collections of several institutions. Once methods were established, in a taxonomic evaluation, two new species were created for the Crato Formation : Araucaria duarteae consisting of bract-scale complexes of the Family Araucariaceae and Pseudofrenelopsis capillata formed by leafy twigs of the Family Cheirolepidiaceae. Within this evaluation, were also included the species Araucaria sp. 1 and A. sp. 2, Araucariostrobus sp. 1 and A. sp. 2 and Brachyphyllum obesum of the Family Araucariaceae in Crato Formation and Cupressinocladus lepidophylla, C. sutamarchensis, Frenelopsis sp. and Pseudofrenelopsis sp. of the Family Cheirolepidiaceae and Araucaroistrobus creutzbergi , A. camargoi , A. signatus and Carpolithes sp. of the Family Araucariaceae in the Paja Formation. These species had their characteristics observed and some of them as succulent stems, fleshy leaves, sunken stomata, thick cuticle, papillae and hairs, seems to be xeromorphic or halophytic adaptations, but is not possible to define one as dominant or exclusive, since lithologies associated with both paleofloras confirm hypersaline environments developed under arid climates .
\end{abstract}




\section{SUMÁRIO}

CAPÍTULO 1 - INTRODUÇÃO 1

1.1. Generalidades $\quad 1$

1.2. Paleogeografia eocretácea 3

1.3. Paleoclima eocretáceo $\quad 3$

1.4. Paleobiota eocretácea $\quad 4$

1.5. Paleofloras eocretáceas $\quad 5$

1.5.1. Marco paleofitogeográfico $r$

$\begin{array}{lr}\text { 1.5.2. Origem das angiospermas } & 10\end{array}$

1.5.3. Floras eocretáceas da América do Sul 13

1.6. Problemática envolvida $\quad 16$

1.7. Hipótese de trabalho $\quad 20$

1.8. Objetivo e metas $\quad 21$

CAPÍTULO 2 - MATERIAL E MÉTODOS 22

2.1. Material de estudo $\quad 22$

2.1.1. Procedência $\quad 22$

2.1.2. Coleções estudadas $\quad 23$

2.2. Métodos $\quad 24$

2.2.1. Revisão bibliográfica $\quad 25$

2.2.2. Métodos de campo $\quad 26$

2.2.3. Visitas técnicas e estágio $\quad 26$

2.2.4. Métodos de laboratório $\quad 29$

2.2.4.1. Preparação mecânica - Limpeza e degàgement 30

2.2.4.2. Preparação mecânica - Lâminas delgadas 31

2.2.4.3. Preparação mecânica - Peels de acetato 32

2.2.4.4. Preparação mecânica - Wafers 33

2.2.4.5. Preparação mecânica - Cortes seriados $\quad 34$

2.2.4.6. Preparação química 34

2.2.5. Métodos ópticos $\quad 35$

2.2.6. Microscopia eletrônica de varredura (MEV) 36

2.2.7. Tomografia e Microtomografia computadorizada 36

2.2.8. Tratamento e interpretação dos dados 37

CAPÍTULO 3 - CONTEXTO GEOLÓGICO E CONTEÚDO FOSSILÍFERO 38

3.1. Contexto geológico e paleoambiental da Formação Crato 38

3.2. Estudos paleobotânicos prévios na Formação Crato 40

3.3. Contexto geológico e paleoambiental da Formação Paja 42

3.3.1. Estudos paleobotânicos prévios na Formação Paja 44

CAPÍTULO 4 - RESULTADOS E DISCUSSÕES $\quad 47$

4.1. Avaliação taxonômica $\quad 47$

4.2. Modos de preservação $\quad 53$

4.2.1. Preservação celular em óxidos de ferro em plantas fósseis da Formação Crato 54

4.3. Fitogeografia $\quad 61$

$\begin{array}{ll}\text { CONCLUSÕES } & 64\end{array}$

$\begin{array}{ll}\text { REFERENNCIAS } & 67\end{array}$

PRANCHAS

ANEXOS 


\section{LISTA DE FIGURAS}

Figura 1.1. Divisão do Período Cretáceo com idades e configuração das massas continentais desde o final do Jurássico (150 Ma) até o final do Cretáceo (65 Ma).

Figura 1.2. Correlação entre os andares internacionais do Eocretáceo e os andares locais brasileiros.

Figura 1.3. Mudanças do pCO2 para os últimos $500 \mathrm{Ma}$.

Figura 1.4. Províncias microflorísticas do Cenomaniano.

Figura 1.5. Províncias microflorísticas do Eocretáceo.

Figura 1.6. Fitogeoprovíncias palinológicas do Eocretáceo.

Figura 1.7. Zoneamento paleoflorístico do Eocretáceo.

Figura 1.8. Províncias florísticas eocretáceas para o Japão e regiões adjacentes.

Figura 1.9. Abundâncias dos principais grupos de plantas desde o Jurássico até o Paleoceno.

Figura 1.10. Localização e composição das principais floras eocretáceas sulamericanas.

Figura 1.11. Empilhamento das porcentagens de cada grupo vegetal nas diferentes paleofloras sulamericanas.

Figura 1.12. Análise de cluster pelo método de ligação do vizinho mais próximo.

Figura 1.13. Empilhamento das porcentagens de cada grupo das paleofloras sulamericanas setentrionais.

Figura 2.1. Mapas de localização das áreas de procedência dos macrofitofósseis estudados.

Figura 3.1. Localização da Bacia do Araripe no nordeste do Brasil e mapa geológico simplificado.

Figura 3.2. Mapa geológico da Formação Crato na área de procedência dos fósseis estudados.

Figura 3.3. Mosaico de imagens da paleofauna da Formação Crato.

Figura 3.4. Mapa digital de terreno mostrando a subdivisão dos Andes Colombianos nas Cordilheiras Ocidental, Central e Oriental.

Figura 3.5. Bloco mostrando o provável ambiente de depositação da Formação Paja na Bacia do Tablazo-Magdalena, com proveniência de sedimentos do Escudo das Guianas.

Figura 4.1. Tipos de preservação dos macrofitofósseis da Formação Crato.

Figura 4.2. Preservação em óxidos de ferro pelo processo de cimentação autigênica em fósseis da Formação Crato.

Figura 4.3. Detalhes epidérmicos e anatômicos preservados tridimensionalmente em fósseis da Formação Crato que sofreram processo de cimentação autigênica.

Figura 4.4. Comparações entre fósseis eocenos piritizados, material recente piritizado experimentalmente e as estruturas encontradas nos fósseis da Formação Crato.

Figura 4.5. A. Análises de espectrometria dispersiva de raio X em corte longitudinal de folha e de células de hipoderme de folha.

Figura 4.6. A. Evidência de atividade microbiana em folha recente deixada em meio aquoso e que foi incrustada com óxidos de ferro. B. Estrutura semelhante a bacteria em fóssil da Formação Crato. C e E. Fósseis piritizados do Eocene London Clay com hifas de fungo em traqueídes. D. Estruturas semelhantes a hifas de fungo em células epidérmicas de folha fóssil da Formação Crato. F. Estruturas semelhantes a hifas de fungo em aparelho estomático de fóssil da Formação Crato.

\section{LISTA DE TABELAS}

Tabela 3.1. Lista de macrofósseis descritos formalmente para a Formação Crato.

Tabela 3.2. Macrofitofósseis da Formação Paja

Tabela 4.1. Coníferas fósseis da Formação Crato

Tabela 4.2. Coníferas fósseis da Formação Paja 


\section{CAPÍTULO 1 - INTRODUÇÃO}

\subsection{Generalidades}

o Período Cretáceo compreende o intervalo de tempo que vai desde, aproximadamente, $145 \mathrm{Ma}$ até os $66 \mathrm{Ma}$, subdividindo-se formalmente em duas épocas, o Eocretáceo e o Neocretáceo, que por sua vez, estão subdivididas em andares, somando um total de 12 para todo o período (Cohen et al. 2013). Estes andares correspondem a intervalos de tempo sucessivos definidos arbitrariamente, mas que podem ser correlacionados ao redor do mundo, sempre que dentro deles haja atributos equivalentes (Figura 1.1).

As correlações cronoestratigráficas deste período são, geralmente, baseadas no conteúdo fossilífero, sendo os grupos fósseis mais relevantes do Cretáceo os amonites, belemnites, foraminíferos planctônicos e nanofósseis, para os estratos marinhos e grãos de pólen e esporos, para os depósitos continentais (Skelton et al. 2003). Como grande parte do Mesozoico nas bacias brasileiras (exceto a partir do Albiano), está composta por sedimentos não marinhos, a ausência de fósseis associados a este ambiente, dificulta sua correlação com os andares internacionais. Esta situação levou à criação de andares locais definidos a partir de zoneamentos bioestratigráficos baseados em palinomorfos e ostracodes (Figura 1.2), mas de aplicação somente em âmbito regional (Schaller, 1969; Viana et al. 1971, Arai et al. 1989). Uma calibração com os andares internacionais foi feita através de eventos microflorísticos globais (Arai et al. 1989). Por sua vez, o Cretáceo da Colômbia, por ser predominantemente composto por sedimentos marinhos, é facilmente correlacionável com os andares internacionais pela presença de uma rica fauna de amonites (Etayo-Serna, 1979; Patarroyo, 2000; Hoedemaeker, 2004). 


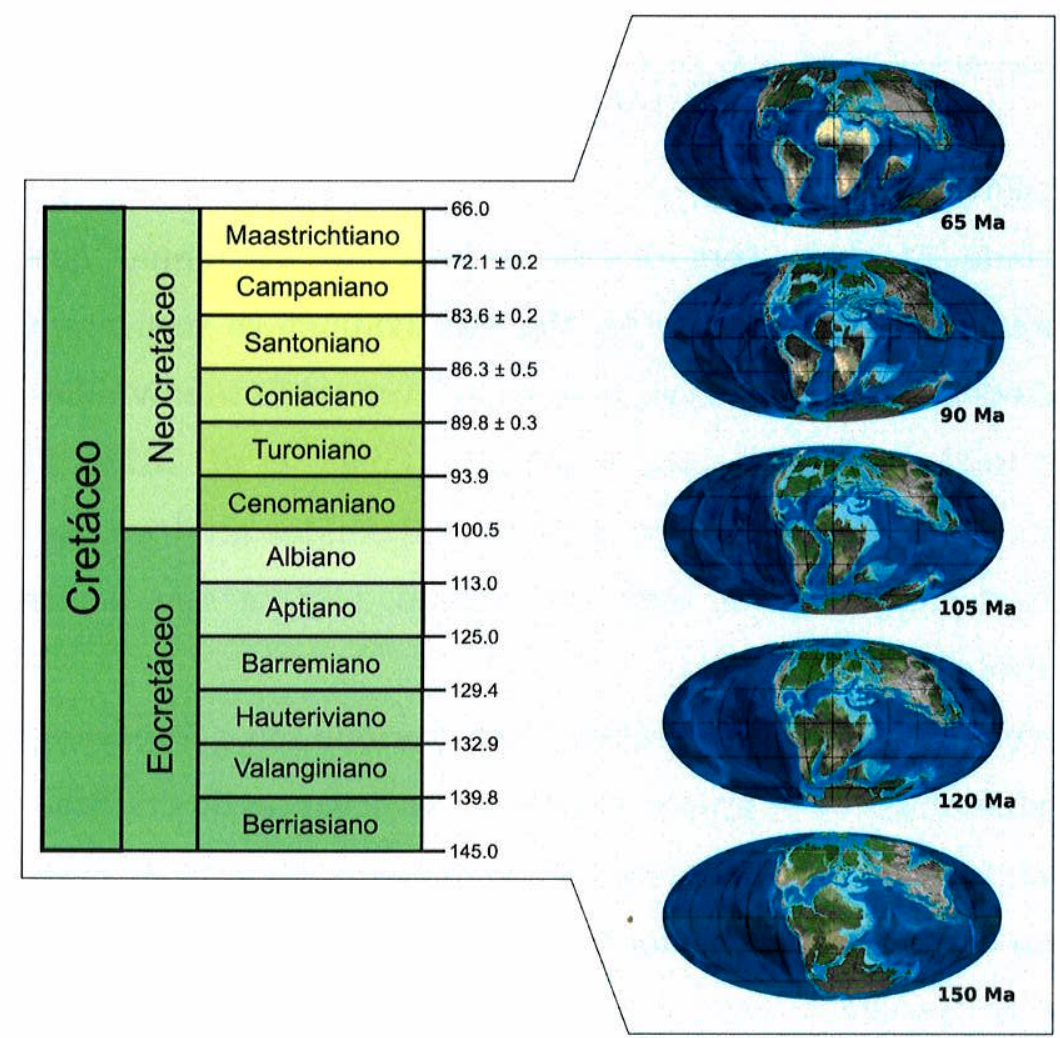

Figura 1.1. Divisão do Período Cretáceo com idades segundo Cohen et al. (2013) e configuração das massas continentais desde o final do Jurássico (150 Ma) até o final do Cretáceo (65 Ma) (modificado de Blakey, 2006).

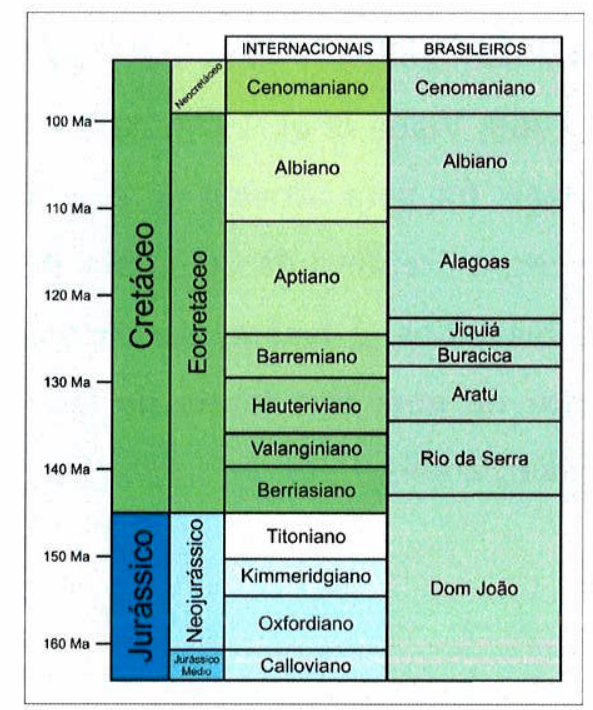

Figura 1.2. Correlação entre os andares internacionais do Eocretáceo e os andares locais brasileiros (modificado de Arai et al. 1989). 
0 Cretáceo foi um período geológico complexo, durante o qual aconteceram eventos que influíram significativamente na vida dos continentes e dos oceanos (Keller, 2008). Episódios abruptos de aquecimento e esfriamento do clima global, inundações marinhas frequentes, eventos anóxicos oceânicos, oscilações no registro de isótopos de carbono e incremento da atividade vulcânica formando as Grandes Províncias Ígneas (LIPs), atuaram de forma individual ou coletiva (Stoll \& Schrag, 1996; Weissert et al. 1998; Jenkyns, 2003; Wissler et al. 2003), modificando as condições ambientais e levando a extinções e/ou diversificações de diferentes grupos de organismos (Larson \& Erba, 1999; Wignall, 2001; Kidder \& Worsley, 2010).

\subsection{Paleogeografia eocretácea}

0 chamado Mundo Cretáceo (Skelton et al. 2003) apresentava grandes diferenças em relação ao mundo atual. No início, os supercontinentes Laurásia, no norte, e Gondwana, no sul, delimitavam um oceano equatorial chamado Mar de Tethys (Figura 1.1). Ao longo do período, estes continentes foram fragmentando-se e novos oceanos surgiram, enquanto o Mar de Tethys se reduziu, resultando no final, numa configuração continental similar à atual. A fragmentação dos continentes, somada à elevação do nível eustático causada pelo deslocamento de massas de água resultantes do aumento na taxa de produção de crosta oceânica, produziram modificações na circulação dos oceanos. Estas modificações conduziram também a uma redistribuição do calor e da umidade atmosféricos.

\subsection{Paleoclima eocretáceo}

Tradicionalmente, o Cretáceo tem sido reconhecido como um período de aquecimento global pronunciado (Frakes et al. 1992), caracterizado por altos níveis de $\mathrm{CO}_{2}$ atmosférico (Barron et al. 1993), e climas mais uniformes com gradiente latitudinal reduzido (Barron, 1983; Sloan \& Barron, 1990; Valdes et al. 1996).

Segundo o modelo de circulação geral obtido por Sellwood \& Valdes (2006) para o final do Jurássico, as temperaturas oceânicas tanto em superfície quanto em profundidade eram mais quentes. Um aumento de, aproximadamente, $8^{\circ} \mathrm{C}$ no fundo do oceano, reduziria a capacidade de armazenamento de $\mathrm{CO}_{2}$ nas águas e de hidratos 
de metano nos sedimentos do fundo, elevando em até quatro vezes os níveis de $\mathrm{CO} 2$ na atmosfera em relação ao presente.

0 regime climático do Cretáceo, principalmente médio e final, apresentava temperaturas maiores que as atuais, como foi demonstrado a partir de: análises de foraminíferos planctônicos (e.g. Bice \& Norris, 2002), plantas (e.g. Herman \& Spicer, 1996) e vertebrados (e.g. Tarduno et al. 1998). 0 teor de $\mathrm{CO}_{2}$ da atmosfera também apresenta evidências de valores mais altos em relação aos atuais (e.g. Berner \& Kothavala, 2001).

Apesar desta aparente correlação entre climas mais quentes e teores atmosféricos maiores de $\mathrm{CO}_{2}$, uma relação de causalidade não tem sido demonstrada e, pelo contrário, em alguns períodos geológicos, aparentemente ocorre uma correlação oposta (Figura 1.3) (Rothman, 2002).

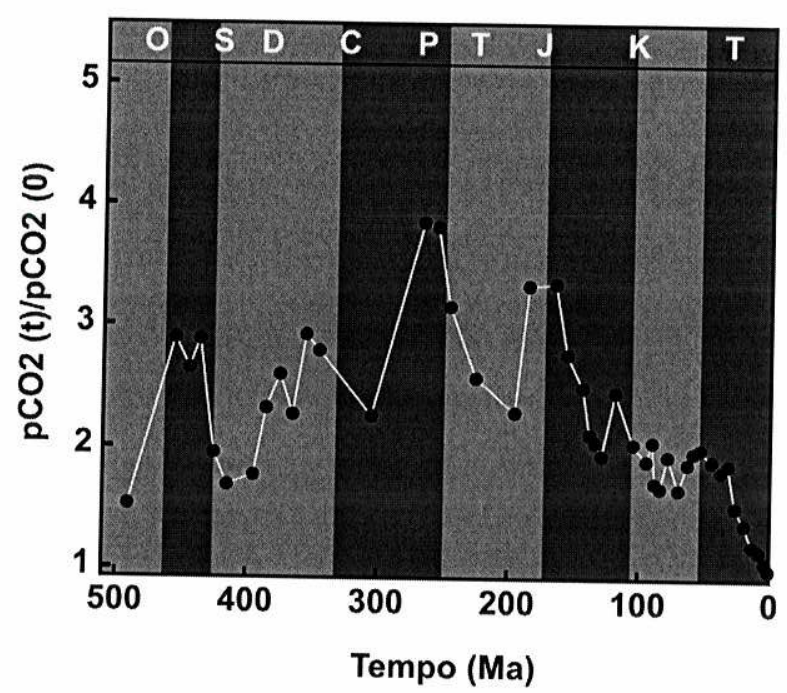

Figura 1.3. Mudanças do pCO2 para os últimos 500 Ma. Faixas escuras correspondem a períodos de clima frio e as claras a períodos de clima quente (modificado de Frakes et al. 1992).

\subsection{Paleobiota eocretácea}

Assim como ocorreram mudanças nas condições geográficas e climáticas do planeta, a biosfera também sofreu modificações. Foi nesta época que os grandes répteis, que dominavam desde o Jurássico, nos continentes (dinossauros), no mar (ictiossauros e plesiossauros) e no ar (pterossauros), sofreram grandes inovações evolutivas e, devido à deriva dos continentes, se diversificaram por vicariância, até sua 
extinção no final do período (Skelton et al. 2003). Ainda, no Eocretáceo, se evidenciou um dos maiores acontecimentos nos ecossistemas terrestres: a primeira diversificação das angiospermas ou plantas com flores (Hughes, 1994; Brenner, 1996; Crane \& Lidgard, 1989). A co-evolução das angiospermas e insetos (que também sofreram uma grande diversificação neste período), constitui um dos fatores que levaram ambos os grupos a se tornarem dominantes na era Cenozóica.

\subsection{Paleofloras eocretáceas}

\subsubsection{Marco paleofitogeográfico}

As floras do Eocretáceo são, quase sempre, discutidas junto com as floras do Neojurássico (Meyen, 1987). Neste intervalo de tempo, a área equatorial era presumidamente muito mais seca e nela dominavam gimnospermas das ordens Cycadales, Bennettitales e Coniferales. As angiospermas eram escassas e só passaram a ser dominantes no Neocretáceo, inicialmente nas latitudes baixas e, posteriormente, nas medianas e altas (Brenner, 1976; Crabtree, 1987; Drinnan \& Crane, 1990).

Durante o Eocretáceo, os gradientes climáticos foram menos marcados do que hoje, graças à maior proximidade entre as massas continentais (Parrish, 1987). As floras de diferentes áreas geográficas podiam exibir gêneros e até espécies em comum e alguns autores concordam com a homogeneidade das floras durante o Eocretáceo (Barnard, 1973; Frakes, 1979).

Embora as diferenças fitogeográficas do Eocretáceo sejam menores que as do Neocretáceo, a uniformidade das primeiras pode ter sido aparente (Batten, 1984). Algumas unidades florísticas territoriais podem ser individualizadas, apesar de apresentar algumas unidades taxonômicas comuns (Meyen, 1987). Vários autores definiram regiões florísticas eocretáceas globais ou geograficamente restritas com base na macroflora ou nos palinomorfos (Krassilov, 1972; Brenner, 1976; Herngreen \& Chlonova, 1981; Srivastava, 1994; Vakhrameev, 1991; Kimura, 2000) (Figuras 1.4 a 1.8).

A classificação proposta por Krassilov (1972) se baseia em elementos dominantes da macroflora eocretácea, para a qual ele define três tipos de flora: a flora Arctomesozóica ou Phoenicopsis, distribuída na Sibéria, Alaska, Canadá e Groenlândia 
Oeste, que é atribuída a uma zona de floresta temperada; a flora Madromesozóica ou Cycadeoidea disseminada pelos Black Hills de Dakota, Freezeout Hills de Wyoming e noroeste de New México, nos Estados Unidos, no Jurássico europeu, parte da Índia, Mongólia e Japão, consideradas como regiões com pronunciada aridez e predomínio de florestas de coníferas; e a flora Notomesozóica ou Pentoxylon, presente na Índia e no hemisfério Sul.

Baseado em assembléias polínicas, Brenner (1976) reconhece quatro províncias florísticas: Laurásia Norte, Laurásia Sul, Gondwana Norte e Gondwana Sul (Figura 1.4). O clima na Laurásia Sul e Gondwana Norte é inferido como estacionalmente seco, com base em dados palinológicos e sedimentológicos, como por exemplo na presença de grãos de pólen similares aos da gimnosperma xerofítica vivente Ephedra, abundante na área setentrional do Gondwana (Brenner 1976; Doyle et al. 1982; Ziegler et al. 1987; Crane \& Lidgard 1989). Na Laurásia Norte e Gondwana Sul, os palinomorfos de fetos e coníferas aparecem em grande quantidade e se interpretam como regiões submetidas a condições climáticas mais frias e úmidas. (Brenner 1976; Ziegler et al. 1987).

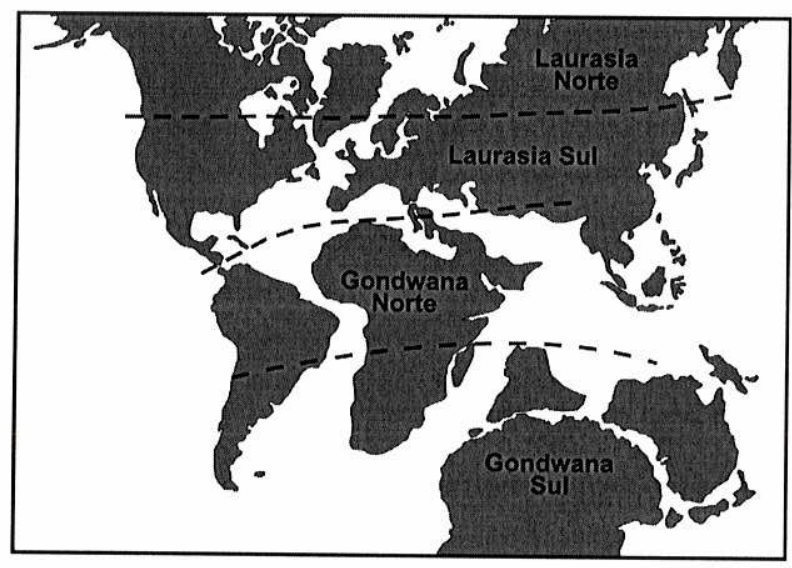

Figura 1.4. Províncias microflorísticas do Cenomaniano segundo Batten (1984).

Herngreen \& Chlonova (1981) definem oito províncias microflorísticas cretáceas com base em palinologia (Figura 1.5). A Província Boreal, no hemisfério norte, caracterizada pela presença de esporos trilete e grãos de pólen bissacados, foi dividida nas Províncias Normapolles e Aquilapollenites, durante o Neocretáceo. A 
Província pré-albiana WASA (West African-South American), onde predominam grãos de pólen de gimnospermas (Classopollis, tipo-Ephedripites, Eucomiidites e Araucariacites), com poucos grãos de pólen bissacados e esporos triletes, fica mais restrita no Cretáceo médio, quando recebe o nome de Província ASA (Africa-South América), sendo caracterizada por abundantes grãos de pólen elaterados e grande diversidade de angiospermas. No Neocretáceo, a abundância de grãos de pólen tipo Palmae, com notável redução de grãos de pólen elaterados, lhe confere o nome de Província Palmae. A Província Gondwana Sul, ocupando Austrália, Índia, Sul da África e da América, durante o Cretáceo médio, era caracterizada pelos grãos de pólen trissacados dos gêneros Microcachryidites e Podosporites. A extensão desta província fica restrita à distribuição de grãos de pólen de Notofaghidites durante o Neocretáceo, pelo que recebe o nome de Província Notofaghidites. Posteriormente, Herngreen et al. (1996) designaram a Província WASA como Província Dicheiropollis etruscus/Afropollis, e a Província ASA como Província Albiano-Cenomaniana de Elaterados.

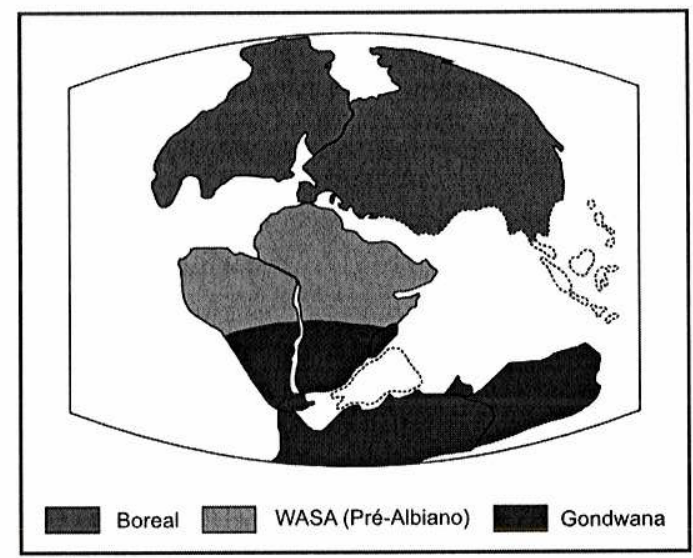

Figura 1.5. Províncias microflorísticas do Eocretáceo segundo Herngreen \& Chlonova (1981), WASA: West African-South American.

Também com base em dados palinológicos, Srivastava (1994) definiu quatro fitogeoprovíncias para o Eocretáceo (Figura 1.6). Durante o Neocomiano, a Fitogeoprovíncia Boreal Cerebropollenites e a Fitogeoprovíncia Austral Microcachyridites, formavam uma faixa em altas latitudes ao norte e sul respectivamente, apresentavam clima úmido e mais frio em relação à 
Fitogeoprovíncia Equatorial Dicheiropollis que possuia um clima mais seco. No intervalo Barremiano-Aptiano, a Fitogeoprovíncia Equatorial Dicheiropollis muda de nome para Fitogeoprovíncia Equatorial de Polens Elaterados, por serem estes os componentes dominantes.

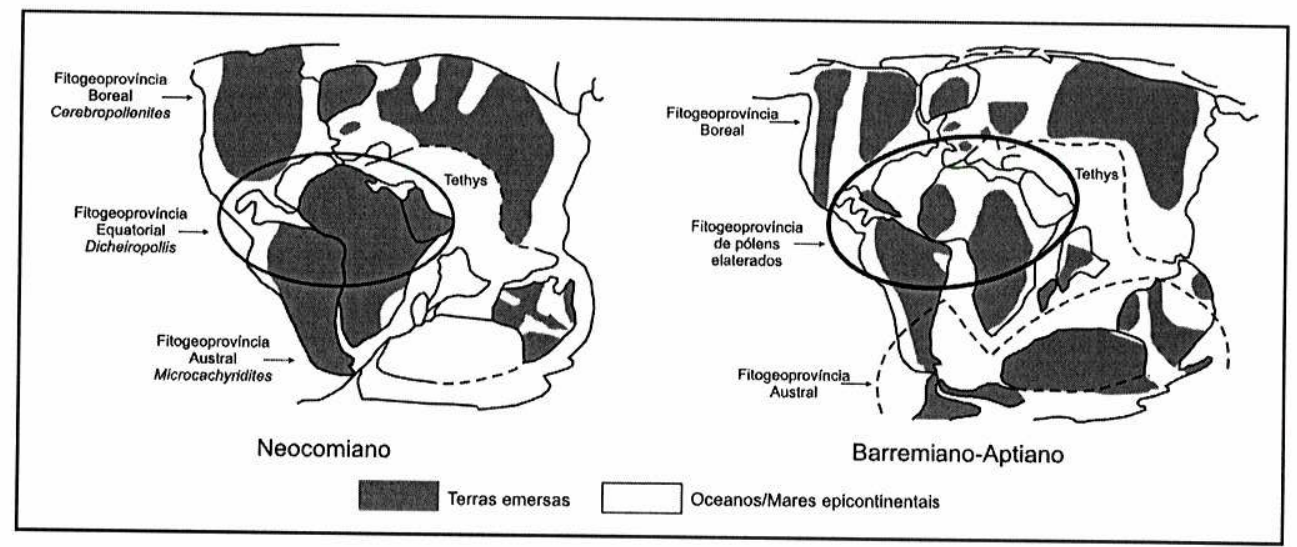

Figura 1.6. Fitogeoprovíncias palinológicas do Eocretáceo segundo Srivastava (1994).

0 zoneamento paleoflorístico de Vakhrameev (1991), para o Eocretáceo em geral, combina dados paleobotânicos e palinológicos para definir quatro regiões (Figura 1.7). A Região Síbero-Canadense abrangia Sibéria, Norte e Nordeste da China, Alaska, Canadá, Spitsbergen, Franz Joseph Land, Nordeste da Plataforma Russa e, possivelmente, a porção mais nórdica da Escandinávia. A região apresentava clima úmido, moderadamente quente e sazonal. Esta região estava provavelmente coberta por densas florestas de coníferas associadas a fetos herbáceos, Equisetum, Cycadales e poucas Bennettitales. As angiospermas só começaram a aparecer no Albiano. A Região Euro-Siniana ocupa a maior parte da Europa, o Cáucaso, parte do Oriente médio e a metade mais sul da Sibéria Oeste, Kazakhstan, Ásia Média, China e os Estados Unidos. 0 clima da parte mais sul era subtropical a quase tropical, com umidade decrescente nas partes média e sul da Eurásia, no oeste o clima era mais úmido. Apresenta um número significativo de Bennettitales e coníferas Cheirolepidiáceas, as angiospermas apareceram no mesoalbiano. A Região Austral ou Notal abrangia o sul da América do Sul, sul da África, Península Antártica, Austrália, Nova Zelândia e a Península Indiana. Apresentava um clima subtropical sazonal, com 
abundantes coníferas das famílias Podocarpaceae, Araucariaceae, Cheirolepidiaceae e escassas Ginkgoales.

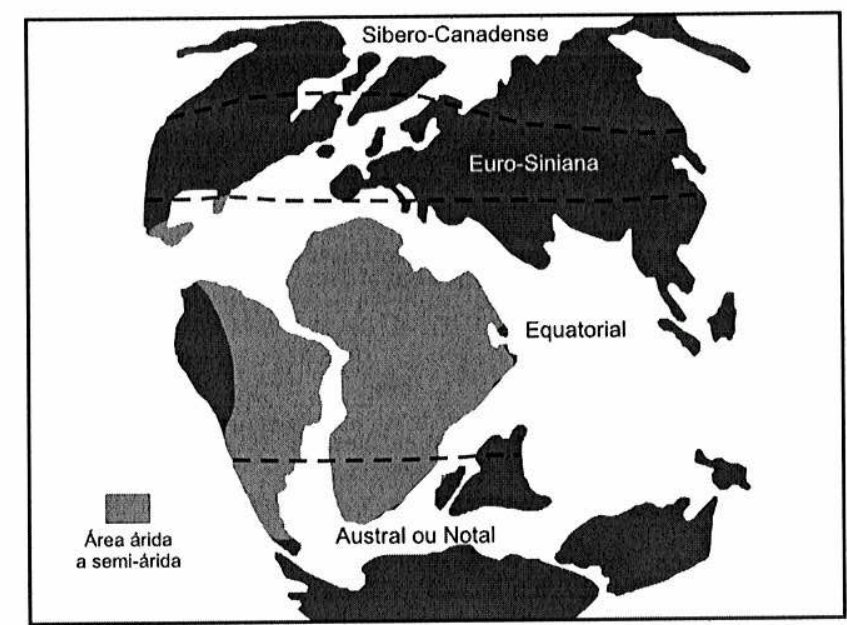

Figura 1.7. Zoneamento paleoflorístico do Eocretáceo segundo Vakhrameev (1991).

A Região Equatorial abrangia quase todo o continente sul-americano (exceto Patagônia e sul do Chile), quase toda a África (exceto África do Sul) e o Sudeste Asiático com poucas áreas emersas, sendo predominantemente ocupado pelos oceanos Pacífico e Índico. As porções equatoriais sul-americana e africana encontravam-se muito próximas e suas floras eram semelhantes. São dominantes os grãos de pólen de coníferas da família Cheirolepidiaceae e de Gnetales, fetos e angiospermas estão, microfloristicamente, diversificados e as Bennettitales encontram-se bem representadas no registro macroflorístico, mas seus grãos de pólen são escassos. Uma área árida a semi-árida cobrindo a maior parte da Região Equatorial e as áreas sulamericana e africana da Região Austral, é definida por Vakhrameev (1991) com base nas porcentagens de grãos de pólen do gênero Classopollis e de polens elaterados.

As três províncias florísticas eocretáceas, com base em elementos macroflorísticos, definidas por Kimura (2000), são restritas ao Japão e regiões adjacentes (Figura 1.8). A do tipo Ryoseki, mais para o sul, apresenta abundantes coníferas Cheirolepidiáceas. Estava submetida a clima tropical a subtropical, sazonalmente, seco. A do tipo Tetori, mais setentrional, tinha como grupo mais 
representativo as Ginkgoales e seu clima era temperado. A do tipo Mista se encontra entre as duas províncias anteriores. É nesta que são encontradas as angiospermas da região e seu clima era subtropical a temperado quente.

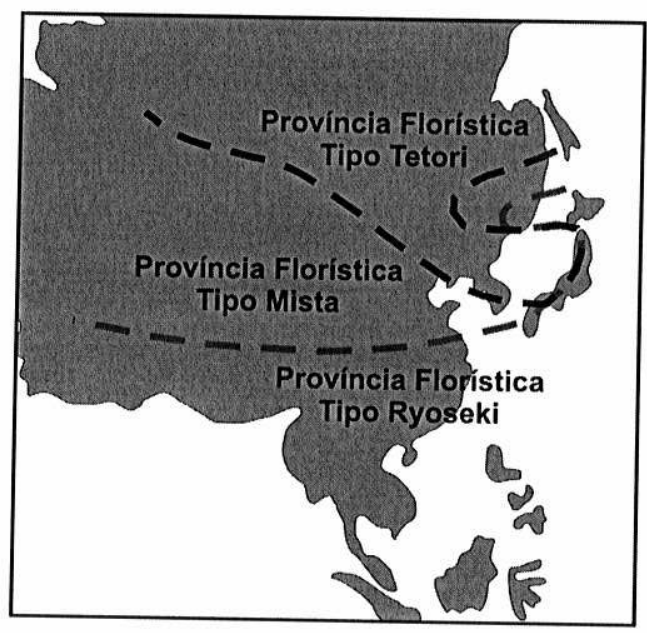

Figura 1.8. Províncias florísticas eocretáceas para o Japão e regiões adjacentes segundo Saiki \& Wang (2003).

\subsubsection{Origem das angiospermas}

Durante o Eocretáceo, ocorreu um dos mais importantes eventos evolutivos na história da vida, a expansão das plantas com flor ou angiospermas (Friis \& Chaloner, 1987; Lidgard \& Crane, 1988, 1990; Crane \& Lidgard, 1989; Crane et al. 1995; Brenner, 1996; Sun et al. 2002). Este evento modificou enormemente os ecossistemas terrestres e permitiu a evolução de muitos outros organismos associados a elas (Lidgard \& Crane, 1990; Labandeira et al. 1994; Wing \& Boucher, 1998; Lupia et al. 1999; Friis et al. 2001; Schneider et al. 2004; Prasad et al. 2005).

Os primórdios da história das plantas com flores constituem um dos acontecimentos mais intrigantes e discutidos da evolução dos ecossistemas terrestres (Crepet et al. 2004; Davies et al. 2004). Em carta ao botânico Joseph Dalton Hooker, em 22 de julho de 1879, Charles Darwin se referiu à rápida diversificação das angiospermas como "o mistério abominável" (Kenrick \& Davis, 2004), mistério que ainda continua sem ser resolvido e que já foi considerado como o único problema em paleontologia comparável em interesse e importância à origem do homem (Stopes, 1912). 
Tradicionalmente, pensa-se que as plantas com flores se originaram em áreas tropicais de baixa latitude e que, posteriormente, migraram para latitudes maiores (Axelrod, 1959; Retallak \& Dilcher, 1981; Lidgard \& Crane, 1990). Esta idéia se deve ao fato de as angiospermas serem, atualmente, mais diversificadas em ambientes tropicais de baixas latitudes (Axelrod, 1952; Takhtajan, 1969), e, aparentemente, o registro de angiospermas eocretáceas parece ser mais abundante nos trópicos que nas latitudes altas (Axelrod, 1959; Doyle et al. 1977). Apesar disso, a hipótese parece não ser, suficientemente, acurada devido ao fato dos registros palinológicos mais antigos de angiospermas, ocorrem tanto em altas quanto em baixas latitudes (Hughes \& McDougall, 1990; Brenner, 1996; Wang et al. 2000). Além disso, os registros mais antigos de macrofósseis de angiospermas ocorrem a partir do Barremiano em latitudes não tropicais, como são a Flora da Formação Patuxent do Grupo Potomac nos Estados Unidos (Hickey \& Doyle, 1977), a Flora da Jingshangou Bed da Formação Yixiang na China (Sun et al. 1998, 2002, 2011; Dilcher et al. 2007), flora barremiana ou aptiana de Portugal (Friis et al. 1994, 1999).

No início do Eocretáceo, as angiospermas estavam ausentes ou apresentavam um caráter subordinado nas floras de diferentes latitudes (Figura 1.9). Apesar de constituir um componente significativo das palinofloras do final do Eocretáceo em baixas latitudes, só foi no final do Albiano que passaram a dominar as latitudes medianas e altas (Brenner, 1976; Crabtree, 1987; Drinnam \& Crane, 1990; Taylor \& Hickey, 1990). 


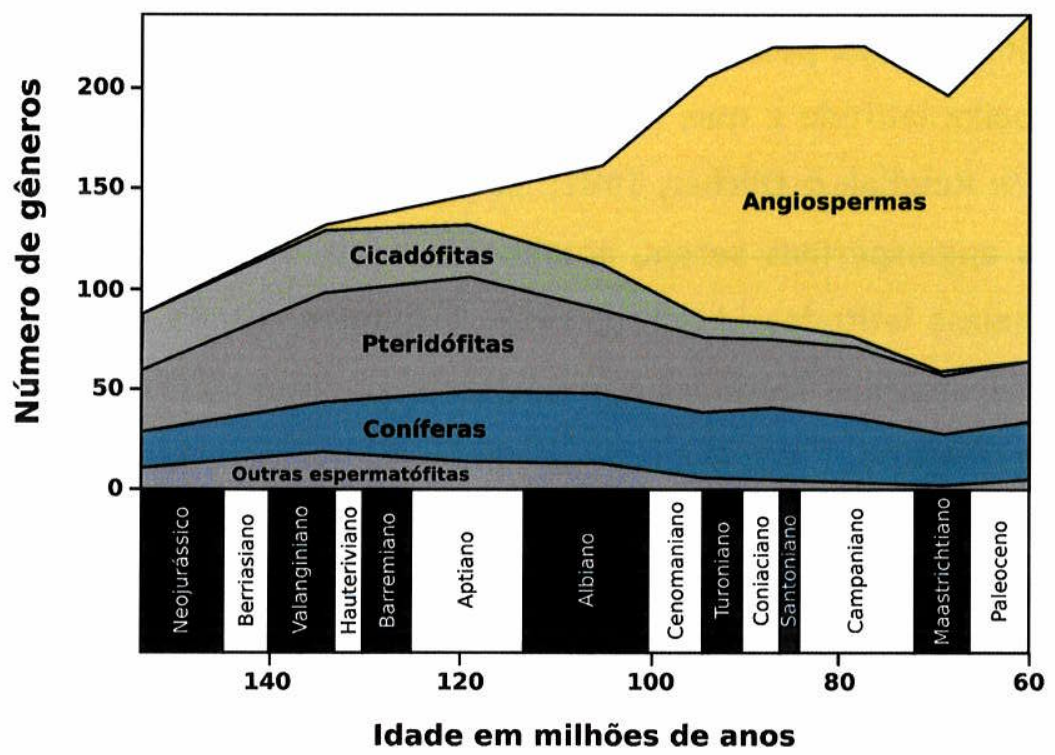

Figura 1.9. Abundâncias dos principais grupos de plantas desde o Jurássico até o Paleoceno (modificado de Crane, 1987)

Vários estudos têm determinado a composição microflorística do Norte de Gondwana que, durante o Eocretáceo, estava dominada por grãos de pólen de gimnospermas, baixa diversidade e abundância de esporos e poucos grãos de pólen de angiospermas (Doyle et al. 1977).

Do mesmo modo, a composição macroflorística eocretácea norte-gondvânica parece estar dominada por gimnospermas, principalmente coníferas (Famílias Araucariaceae e Cheirolepidiaceae) e Bennettitales, com abundâncias locais de fetos e poucas ocorrências de angiospermas (Vakhrameev, 1991).

São poucas as floras do Eocretáceo que apresentam um componente significativo de macrofósseis de angiospermas. No Hemisfério Sul, a flora albiana de Koonwarra, na Austrália, apresenta uma única forma de hábito herbáceo (Taylor \& Hickey, 1990) e um só tipo de grão de pólen de angiosperma entre 62 táxons reconhecidos (Dettmann 1986). Floras eocretáceas da África do Sul, apresentam alguns poucos tipos de grãos de pólen angiospérmicos (Anderson \& Anderson, 1983, 1985; Drinnan \& Crane, 1990) e nenhum macrofóssil, assim como acontece com floras barremianas a aptianas do sul da Argentina (Archangelsky 1980; Romero \& Archangelsky, 1986). As angiospermas também foram raras ou ausentes em latitudes 
médias do hemisfério norte, durante o Aptiano (LaPasha \& Miller 1984), e foram completamente ausentes nas floras árticas até quase o final do Albiano (Spicer 1990). Algumas floras albianas dos Estados Unidos, como a do Grupo Potomac e da Formação Winthrop, apresentam um componente significativo de morfotipos foliares de angiospermas (Doyle \& Hickey, 1976; Miller et al. 2006).

Embora a proliferação das angiospermas, no Cretáceo, tenha sido acompanhada pelo declínio de muitas linhagens de plantas vasculares com semente livre, sua radiação também criou novos espaços ecológicos nos quais certas linhagens poderiam ter se diversificado, como é o caso dos fetos polypodiales, que se presume, diversificaram-se sob a sombra das angiospermas (Schneider et al. 2004).

\subsubsection{Floras eocretáceas da America do Sul}

As floras eocretáceas da área equatorial da América do Sul, apesar de serem abundantes, são relativamente pouco conhecidas. No Brasil, foram registrados macrofitofósseis no Eocretáceo de várias bacias e.g. Recôncavo, Tucano-Jatobá, Sergipe-Alagoas, Araripe (e.g. Duarte \& Japiassú, 1971; Mendes \& Petri, 1971; Bernardes-de-Oliveira et al. 2007). A bacia do Araripe é a que possui maior quantidade de estudos sistemáticos (Mohr \& Rydin, 2002; Mohr \& Eklund, 2003; Kunzmann et al. 2004, 2006, 2007, 2009, 2011; Mohr \& Bernardes-de-Oliveira, 2004; Dilcher et al, 2005; Mohr et al. 2006, 2009, 2012, 2013; Coiffard et al. 2013). Na Colômbia, estão documentadas duas paleofloras equatoriais eocretáceas nos Andes Orientais, uma na Região de Villa de Leyva (Huertas, 1967, 1970, 1971, 1976, 2003; Van Waveren et al. 2002) e outra no Macizo de Quetame (Pons, 1982a, 1982b, 1988), nos Andes Centrais existe registro de duas paleofloras, uma mais antiga da Formação Valle Alto e outra da Quebrada Campanas (Lemoigne, 1984). Há também registros de macrofloras eocretáceas na Venezuela (Royo y Gómez, 1960; Pfefferkorn, 1977), Equador (Shoemaker, 1977), Peru (Berry, 1922; 1939; INGEMMET, 1995; Romero et al. 1995) e Norte do Chile (Chong, 1976).

As floras eocretáceas do sul da América do Sul são, igualmente, abundantes, dentre as quais as argentinas são as mais conhecidas, principalmente aquelas da Província de Santa Cruz (e.g. Archangelsky, 1963a, 1963b, 1963c, 1964; Archangelsky 
\& Baldoni, 1972a, 1972b; Villar de Seoane, 1995; Del Fueyo \& Archangelsky, 2002; Passalia, 2007; Limarino et al. 2012).

Numa análise comparativa da composição das paleofloras sulamericanas com maior número de espécies descritas (Formação Valle Alto e Formação Paja na Colômbia, ocorrências fitofossilíferas de Huallanca no Departamento de Huanuco e da Ilha de San Lorenzo, em El Callao, no Perú, Formação Crato, no Brasil, Grupo Baqueró, Formação Kachaike e Formação Springhill, na Argentina), agrupadas segundo categoria taxonômica de Ordem ou Divisão (Figura 1.10 com lista de espécies no Anexo 1), notam-se algumas semelhanças e diferenças entre elas.

As coníferas aparecem como constituintes predominantes nas duas paleofloras tratadas nesta tese. Entre elas, aparecem elementos considerados como indicadores de climas áridos como o gênero Pseudofrenelopsis (Família Cheirolepidiaceae). Outra característica em comum é o componente angiospérmico, medianamente, diversificado e a baixa quantidade de elementos do grupo das pteridófitas. As Bennettitales são o grupo mais diversificado na paleoflora da Formação Valle Alto, na Colômbia, e da Formação. Springihill, na Argentina. As pteridófitas são o principal constituinte das floras peruanas e da flora da Formação Kachaike, na Argentina. Outros grupos como Cycadales, Pteridospermales e a folhagem de afinidade incerta se encontram em quantidades variáveis, mas nunca dominantes em flora alguma. 0 grupo da folhagem com afinidade incerta se compõe de espécies relacionadas com Pteridófitas ou Pteridospermas. Outros grupos tem restrições geográficas, como é o caso das Ginkgoales, que estão presentes unicamente nas floras meridionais da América do Sul e das Gnetales que até o momento, são exclusivas da flora da Formação Crato, onde apresentam grande diversidade. 


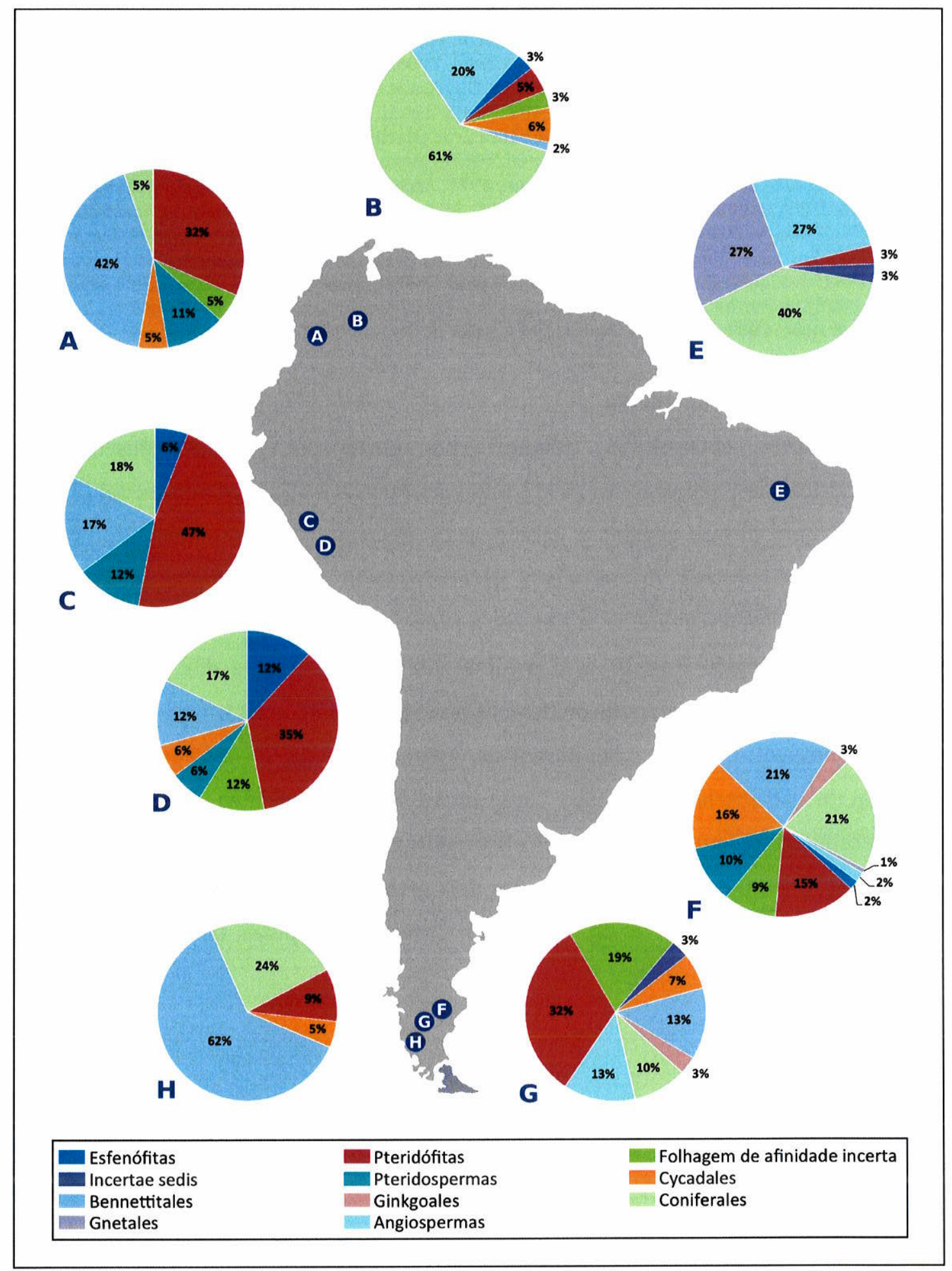

Figura 1.10. Localização e composição das principais floras eocretáceas sulamericanas. A. Formação Valle Alto, Colômbia (Lemoigne, 1984). B. Formação Paja na Região de Villa de Leyva, Colômbia (Huertas, 1967, 1970, 1971, 1976, 2003; Pons, 1982a, 1982b, 1988; Van Waveren et al. 2002). C. 
Huallanca no Departamento de Huanuco, Peru (Berry, 1922, 1939). D. Ilha de San Lorenzo, El Callao, Peru (Berry, 1922, 1939). E. Formação Crato (Duarte, 1985, 1989, 1993; Mohr \& Rydin, 2002; Mohr \& Eklund, 2003; Rydin et al. 2003; Kunzmann et al. 2004, 2006, 2007, 2009, 2011; Mohr \& Bernardes-deOliveira, 2004; Dilcher et al. 2005; Bernardes-de-Oliveira et al. 2006; Fanton et al. 2006; Mohr et al. 2006, 2008, 2012, 2013; Kerkhoff \& Dutra 2007; Coiffard et al. 2013; Leme et al. (no prelo); Löwe et al. (no prelo)). F. Grupo Baqueró, Província de Santa Cruz (Herbst, 1962; Archangelsky, 1963a, 1963b, 1963c, 1964a, 1964b, 1965a, 1965b, 1966, 1967a; Menendez, 1965, 1966; Traverso, 1966; Archangelsky \& Baldoni, 1972a, 1972b; Baldoni, 1974; Archangelsky \& Taylor, 1986; Archangelsky \& del Fueyo, 1989; Del Fueyo et al. 1990, 2007, 2009; Archangelsky et al. 1995; Villar de Seoane, 1996, 1997, 1999, 2005; Del Fueyo \& Archangelsky, 2002; Archangelsky \& Villar de Seoane, 2004; Limarino et al. 2012). G. Formação Kachaike, Provincia de Santa Cruz (Halle, 1913; Archangelsky, 1967b; Baldoni, 1980b, 1981; Baldoni \& Ramos, 1981; Longobuco et al. 1985; Cuneo \& Gandolfo, 2005; Del Fueyo et al.

2007, 2008). H. Formação Springhill, Província de Santa Cruz (Archangelsky, 1979; Baldoni, 1979;

Cortiñas \& Arbe, 1981; Baldoni \& Taylor, 1983; Villar de Seoane, 1995, 2001; Del Fueyo et al. 2007).

\subsection{Problemática envolvida}

As floras eocretáceas sulamericanas pertencem a duas das regiões paleoflorísticas de Vakhrameev (1991), a Região Austral e a Região Equatorial (Figura 1.7). Cada uma dessas regiões é considerada de composição florística uniforme e diferenciada das outras. Apesar disto, na composição destas paleofloras, nenhuma diferença latitudinal é evidente, a não ser a presença de Ginkgoales em duas das três paleofloras da Região Austral e a presença de Gnetales numa das paleofloras da Região Equatorial, como se pode evidenciar nas Figuras 1.10 e 1.11.

É notável que as paleofloras da Formação Paja e da Formação Crato apresentam características na sua composição, muito diferentes das outras floras consideradas, o que também pode ser observado na Figura 1.12, onde uma análise de agrupamento simples coloca as floras em dois grupos principais, um composto pelas floras da Formação Paja e da Formação Crato, outro pelas demais paleofloras sulamericanas. 


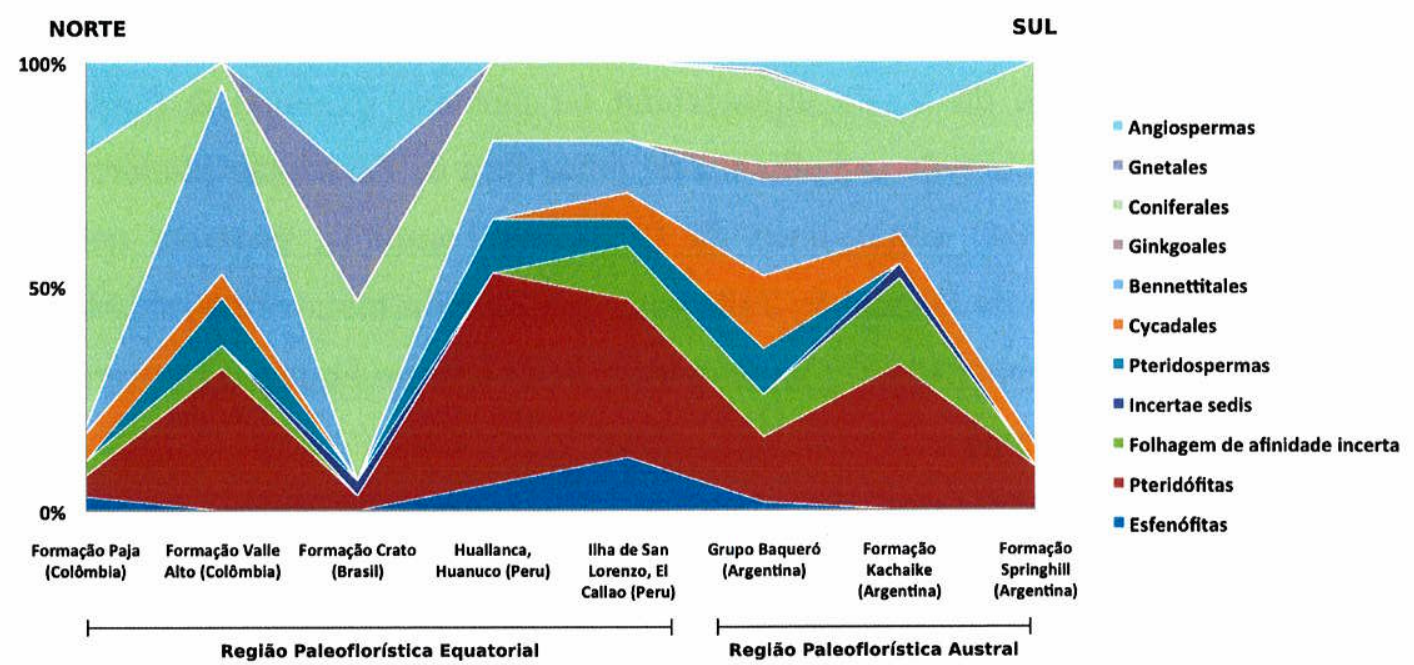

Figura 1.11. Empilhamento das porcentagens de cada grupo vegetal nas diferentes paleofloras sulamericanas mostrando a falta de um padrão latitudinal na composição e impossibilidade de diferenciar entre as composições das paleofloras pertencentes às regiões paleoflorísticas Equatorial e Austral.

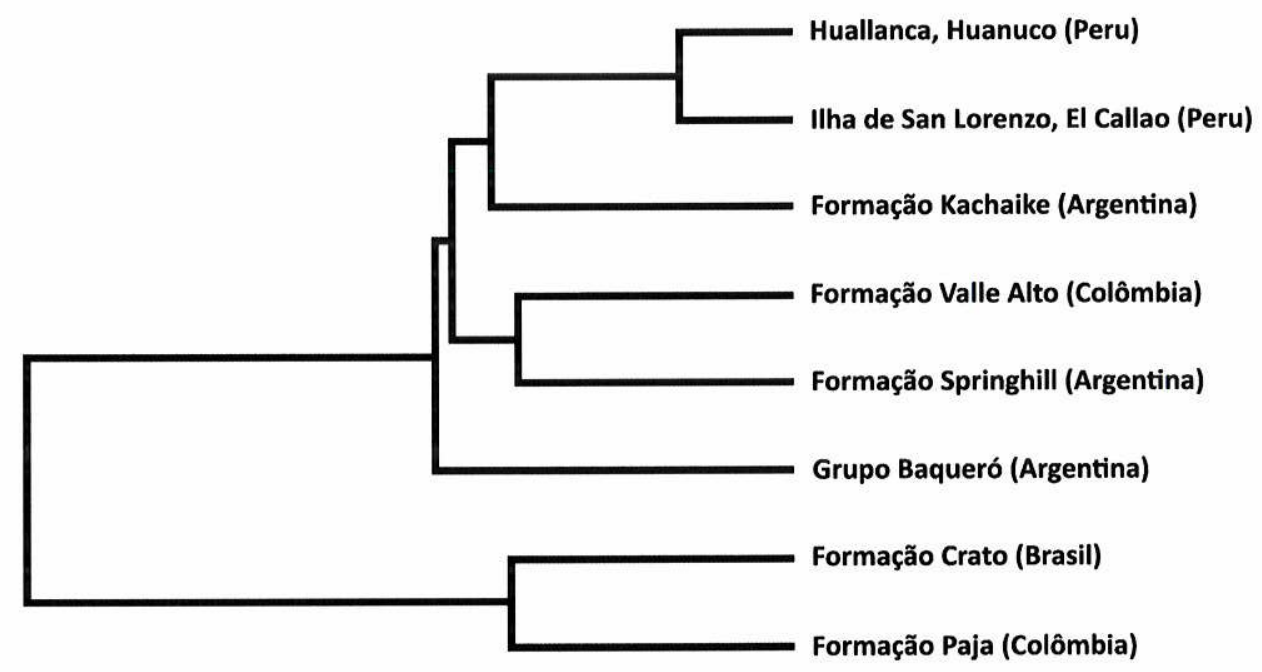

Figura 1.12. Análise de cluster pelo método de ligação do vizinho mais próximo, determinado pelo coeficiente de correlação para medir a similaridade entre as diferentes paleofloras sulamericanas, usando o software PAST versão $2.17 \mathrm{c}$.

Analisando a Figura 1.12, percebe-se quanto a composição taxonômica das paleofloras colombianas, um agrupamento da Formação Valle Alto, com as paleofloras peruanas e as argentinas e não com a paleoflora de maior proximidade geográfica, a da Formação Paja. Isto poderia ser explicado no contexto da evolução tectônica Sulamericana e do Caribe, já que a Formação Valle Alto faz parte de um bloco 
acrecionado durante o final do Cretáceo à margem ocidental do continente, e que teria sido formado perto da borda equatoriana ou peruana (Kennan \& Pindell, 2009). Evidenciado, também, pela semelhança da paleoflora da Formação Abejorral descrita por Lemoigne (1984) como flora da Quebrada Campana, próxima geográfica e estratigráficamente da Formação Valle Alto, porém com menor diversidade e a flora descrita por Shoemaker (1982) na Província de El Oro no Equador (Moreno-Sánchez \& Pardo-Trujillo, 2003).

0 estabelecimento de padrões biogeográficos entre as paleofloras sulamericanas torna-se difícil, também, pela baixa resolução cronológica de algumas delas. Por exemplo, a Formação Valle Alto para a qual foi atribuída uma idade berriasiana-valanginiana (Etayo-Serna, 1985; Mojica \& Dorado, 1987), com base na presença de alguns poucos amonites considerados dessas idades e não à definição de alguma biozona característica. No caso das paleofloras peruanas, a idade é considerada anterior ao Valanginiano (Berry, 1922). Nas três paleofloras anteriores também foi cogitada a possibilidade de terem uma idade jurássica, devido à composição florística semelhante à de outras floras jurássicas. Entretanto, deve-se ressaltar que o limite florístico entre o Jurássico e o Eocretáceo não está muito bem definido.

As floras da parte setentrional da América do Sul, com idade melhor definida, são as estudadas nesta tese: a da Formação Paja, na área de Villa de Leyva, que é considerada como hauteriviana a neoaptiana, com base em zoneamentos bioestratigráficos de amonites (Etayo-Serna, 1979; Etayo-Serna et al. 1986; Patarroyo \& Moreno, 1997, Patarroyo, 2000) e a da Formação Crato, definida como neoaptiana com base em zoneamentos bioestratigráficos de palinologia e ostracodes (Arai et al. 2001).

Na Argentina, o Grupo Baqueró teria sido depositado durante o meso a neoptiano como atestam datações isotópicas dos sedimentos vulcânicos que contém a paleoflora (Césari et al. 2011; Limarino et al. 2012). A Formação Kachaike, segundo dados palinológicos, tem uma idade albiana (Barreda \& Archangelsky, 2006; Guler \& Archangelsky, 2006). Para a Formação Springhill é dada uma idade berriasiana com base em amonites na área do Lago San Martin (Riccardi, 1977) e berriasiana- 
valanginiana baseada em palinologia, de subsuperfície na bacia Austral (Baldoni \& Archangelsky, 1983).

Em particular, para a Região Equatorial, que abrangiria as paleofloras da parte mais setentrional da América do Sul, incluídas as duas estudadas nesta tese, parece existir uma variação longitudinal de composição (Figura 1.13), com os grupos das Coniferales, Pteridófitas, Angiospermas, Gnetales e Bennettitales como seus principais determinantes. As Pteridófitas e Bennettitales aparecem mais abundantes a oeste e diminuem consideravelmente ou desaparecem (no caso das Bennettitales) a leste. Contrariamente, as Coniferales passam de um grupo pouco representativo a oeste para o grupo dominante a leste. As Angiospermas estão ausentes nas floras mais ocidentais e as Gnetales ocorrem somente na paleoflora da Formação Crato localizada na porção oriental.

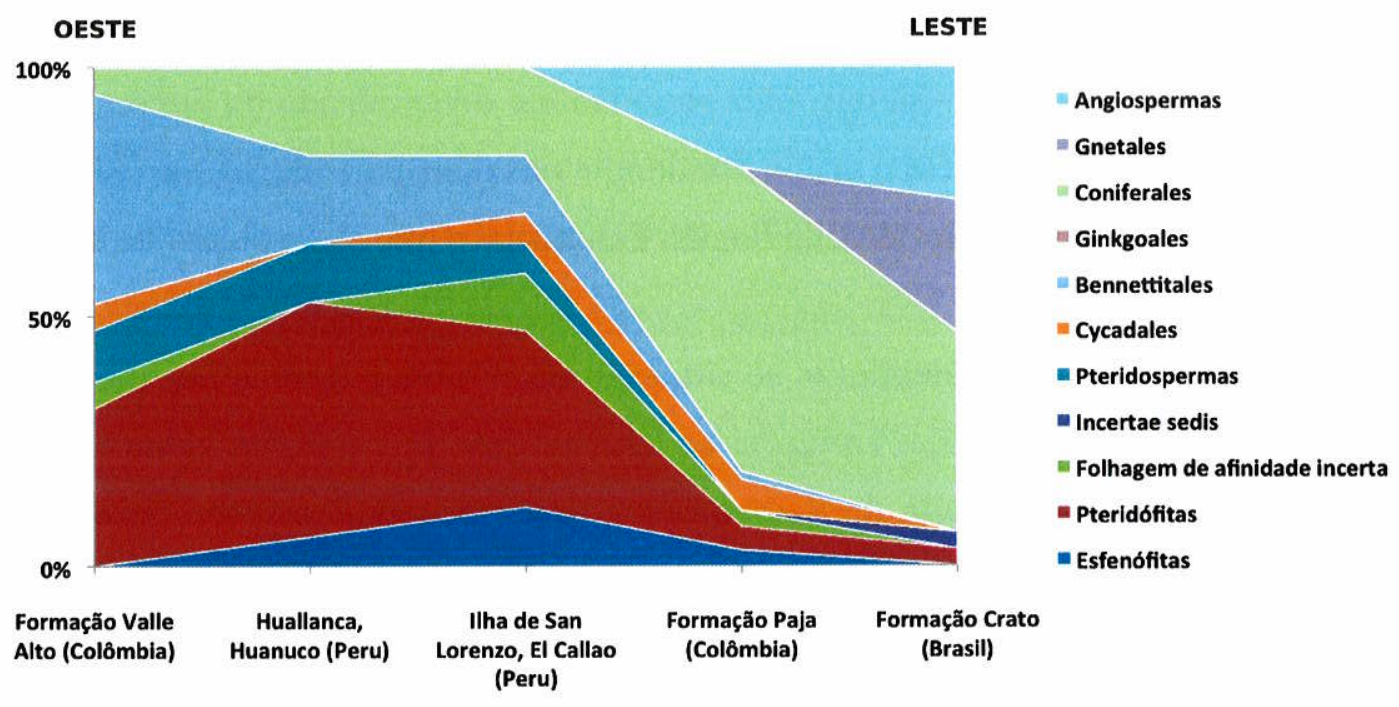

Figura 1.13. Empilhamento das porcentagens de cada grupo das paleofloras sulamericanas setentrionais mostrando um aparente padrão longitudinal na composição.

Estas diferenças composicionais poderiam ser explicadas por razões climáticas, com a presença de uma faixa de maior umidade na regiáo costeira ocidental do continente, o que justificaria a abundância de pteridófitas a oeste e de gnetales a leste, onde a umidade oceânica não chegaria devido ao fato de estar no interior do Gondwana, (ainda não fragmentado) submetido portanto a um clima continental mais 
seco. Este fenômeno é apresentado por Hay \& Floegel (2012) como Efeito Supercontinente.

0 estudo das floras eocretáceas sul-americanas da Região Equatorial é importante no entendimento da evolução vegetal e dos ecossistemas terrestres, já que os paleotrópicos, onde estariam inseridas estas paleofloras podem aportar informações importantes sobre a origem e/ou a diversificação inicial do grupo vegetal atualmente dominante, as angiospermas, na época eocretácea, quando os ecossistemas ainda eram dominados pelas gimnospermas. As áreas tropicais atuais são, florísticamente, consideradas de grande importância ecológica, devido ao fato de apresentarem a maior diversidade e abundância de espécies vegetais viventes, quase todas pertencentes ao grupo das angiospermas. Entretanto, durante o Eocretáceo, a predominância das gimnospermas sobre as angiospermas era marcante nessas áreas. Macrofitofósseis dessa idade, na Região Equatorial da América do Sul, são ainda pouco estudados, apesar de serem abundantes e conhecidos desde meados do século XX.

Um dos grupos vegetais mais abundante e diversificado do Eocretáceo é o das coníferas. Elas constituem o grupo dominante nas duas paleofloras, aproximadamente coetâneas, melhor conhecidas, da Região Equatorial e que são o objeto de estudo nesta tese.

O fato dessas paleofloras se situarem na mesma província, ajudaria a melhor caraterizá-la, e estabelecer variações ao interior dela. As coníferas, como o grupo mais abundante e diversificado do Eocretáceo, e presente nas duas paleofloras, com bom grau de preservação, poderiam melhor refletir as adaptações relacionadas a diferenças ambientais e padrões fitogeográficos.

\subsection{Hipótese de trabalho}

As duas paleofloras analisadas apresentam semelhanças nos seus componentes do grupo das coníferas por terem coexistido dentro da mesma região paleoflorística durante o Neoaptiano. As diferenças encontradas entre os componentes do grupo das coníferas estão relacionadas com o regime climático ao qual foi submetida cada uma dessas paleofloras e com o ambiente de depositação. Será possível subdividir a Região Paleoflorística Equatorial com base na diversidade encontrada. 


\subsection{Objetivo e metas}

0 objetivo deste projeto de doutorado é verificar que existem semelhanças e diferenças na composição de duas paleofloras eocretáceas (a da Formação Crato, no Brasil e a Formação Paja, na Colômbia), da Região Paleoflorística Equatorial da América do Sul, e determinar os seus prováveis fatores (paleoclimáticos, paleoecológicos, evolutivos e/ou tectônicos).

Para atingir o objetivo, as metas propostas foram:

- Avaliação taxonômica dos elementos pressupostamente da Ordem Coniferales das paleofloras mencionadas, usando caracteres morfológicos e quando foi possível, caracteres anatômicos.

- Análise do tipo de preservação dos fósseis estudados para entender os processos de fossilização aos quais foram submetidos.

- Análise conjunto das histórias geológicas das áreas de ocorrência dos fósseis e de suas características morfológicas e anatômicas, para entender as condições paleoambientais, paleoclimáticas e possíveis padrões biogeográficos. 


\section{CAPÍTULO 2 - MATERIAL E MÉTODOS}

\subsection{Material de estudo}

0 material estudado compõe-se de macrofitofósseis que procedem de duas unidades litológicas, a Formação Crato, no Brasil e a Formação Paja, na Colômbia. Consta de fósseis de organismos inteiros ou fragmentos de eles como folhas, ramos folhosos, megaestróbilos, microestróbilos e megaesporófilos com brácteas. No caso do material da Formação Crato, a preservação é predominantemente, na forma de moldes de óxidos de ferro e, raramente, incarbonizações, ambos contidos em calcários finamente laminados. 0 material proveniente da Formação Paja se constitui de fósseis geralmente tridimensionais preservados como petrificações, as vezes recristalizadas, e contidas em concreções calcárias associadas a folhelhos pretos. (ver detalhamento no Anexo 2).

Material vegetal recente usado para comparação com os fósseis tem sido coletado ou observado diretamente nos jardins do Instituto de Geociências e do Instituto de Biociências da USP. Foi observado também, material herborizado disponível no Herbário do Instituto de Biociências da USP e do Museum Botanicum Berolinense (Alemanha).

\subsubsection{Procedência}

Os macrofitofósseis da Formação Crato aqui estudados, são presumidamente procedentes das pedreiras de calcários laminados, conhecidos comercialmente como Pedra Cariri, que afloram entre os municípios de Nova Olinda e Santana do Cariri às margens da rodovia CE-166 (e.g. Mina Triunfo), nos arredores do Geossítio Nova Olinda do Geopark Araripe, no Estado de Ceará (Figura 2.1).

Os fósseis da Formação Paja considerados neste estudo, são originários dos arredores do Município de Villa de Leyva, área a oeste e sul deste município limitada pelos municípios de Santa Sofia ao norte, Sáchica ao sul e Sutamarchan a oeste, no Departamento de Boyacá, Colômbia (Figura 2.1). A flora desta formação ocorre em nódulos calcários contidos em argilitos, que podem ser encontrados nas localidades 
de Loma de Puntillas, Loma Barranco Hondo, Loma La Yuca, La Yesera e Monastério de Santo Ecce Homo.
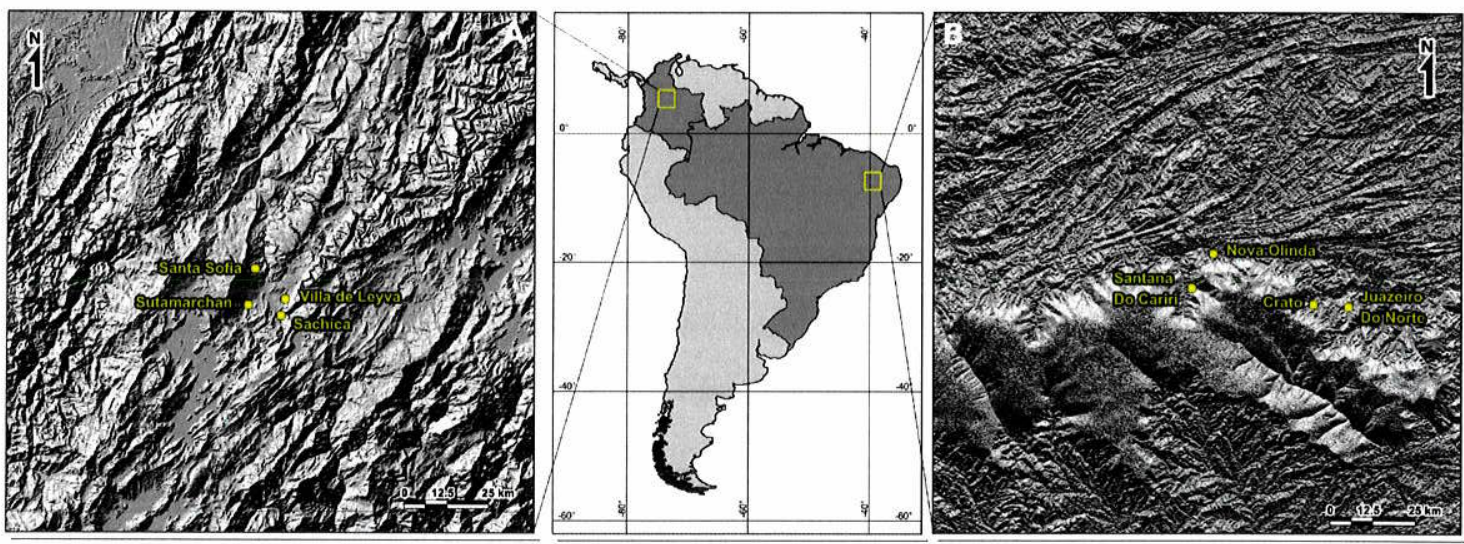

Figura 2.1. Mapas de localização das áreas de procedência dos macrofitofósseis estudados. A. Município de Villa de Leyva e arredores onde aflora a Formação Paja. B. Município de Nova Olinda e arredores onde afloram a Formação Crato.

\subsubsection{Coleções estudadas}

Os espécimes provenientes da Formação Crato, fazem parte das seguintes coleções científicas no Brasil: Laboratório de Paleontologia Sistemática do Instituto de Geociências da Universidade de São Paulo; Museu Paleontológico de Santana do Cariri da Universidade Regional do Cariri, Santana do Cariri-CE; Museu dos Fósseis do DNPM, Crato-CE; Museu Nacional de Rio de Janeiro, UFRJ; Instituto de Geociências da UFRJ. Coleções científicas na Alemanha também foram examinadas, nas seguintes instituições: Museum für Naturkunde der Humboldt-Universität, Berlim; do Senckenberg Forschungsinstitut und Naturmuseum, Frankfurt; do Senckenberg Naturhistorische Sammlungen, Dresden.

Os espécimes estudados da Formação Paja, pertencem à coleção científica do Laboratório de Paleontologia da Universidad de Caldas, Manizales e à coleção Padre Huertas da Universidad Nacional de Colombia, Bogotá.

Para verificar diferenças de origem evolutiva e/ou paleoambiental, entre dois gêneros de ramos folhosos, Pseudofrenelopsis e Brachyphyllum, presentes nas duas paleofloras estudadas, foram observados alguns fósseis da Formação Romualdo, de posição estratigráfica acima da Formação Crato dentro da bacia do Araripe e de idade ligeiramente mais jovem, Aptiano/Albiano. Estes fazem parte da coleção científica do 
Laboratório de Paleontologia Sistemática do Instituto de Geociências da Universidade de São Paulo e do Museu Paleontológico de Santana do Cariri da Universidade Regional do Cariri, CE.

Um detalhamento das amostras analisadas nesta tese, assim como suas coleções depositárias com código de catalogação se encontra no Anexo 2.

\subsection{Métodos}

Os objetivos de estudo de plantas fósseis podem ser muito variados, incluindo desde o seu uso como indicadores paleoambientais, paleoclimáticos e paleogeográficos, passando por sua utilização no entendimento de relações evolutivas nos vegetais, ou para descobrir quando surgiram ou se extinguiram os principais grupos de plantas, até sua relação com outros grupos de seres vivos e suas influências nos processos superficiais da terra.

Independentemente da aplicação final do estudo de plantas fósseis e da complexidade da análise desejada, o primeiro passo é a catalogação e classificação taxonômica dos fitofósseis em estudo. Esta identificação leva muitas vezes à reconstituição total ou parcial de espécies, com seus hábitos de vida e relações ambientais (paleobiologia e paleoecologia). Outras vezes, quando é mais importante o uso dos fósseis como indicadores paleoambientais, a identificação de espécies não se faz tão necessária e sim a classificação de suas feições morfoadaptativas, em grupos vegetacionais com características semelhantes.

A ferramenta mais importante é a observação direta ou indireta das características morfológicas e anatômicas dos espécimes para depois comparar com outros fósseis já descritos na literatura ou com plantas viventes com características semelhantes. Para uma correta observação dos fitofósseis, é necessária inicialmente uma limpeza cuidadosa de cada um dos espécimes e o uso de preparações destrutivas ou não para análise de feições internas.

Os métodos utilizados nesta etapa dependeram do tipo de preservação dos fitofósseis em estudo e dos objetivos finais da pesquisa. A quantidade de amostras analisadas é dependente do tipo de resultado esperado: a) para reconstituições paleoclimáticas é necessária uma amostragem sistemática com adequada 
representatividade estatística, exaustiva coleta de dados tafonômicos, identificação de fósseis associados e acurado posicionamento estratigráfico e geográfico dos níveis fossilíferos; b) em análises paleobiológicas, apesar da amostragem abundante aumentar a exatidão das reconstituições, devido à maior probabilidade de encontrar feições bem preservadas de todos os órgãos da planta, muitas vezes, se trabalha com espécimes únicos, que nem sempre são coletados junto com dados estratigráficos e tafonômicos acurados. Entretanto, podem possuir grande importância taxonômica e devem ser identificados, uma vez que sejam estabelecidas sua localização geográfica e estratigráfica aproximadas. De certa forma, esse é o caso dos fitofósseis das paleofloras estudadas neste trabalho.

A maioria das amostras estudadas nesta tese, provem de coleções preexistentes, que geralmente são tendenciosas e restritas a exemplares melhor preservados e mais completos, deixando de lado aqueles fragmentados. Alguns táxons, por suas características físicas ou por eventos bioestratinômicos como, por exemplo, a distância do local de crescimento até o local do soterramento final, possuem menor potencial de preservação. Estes, raramente serão preservados de uma forma melhor ou talvez nunca sejam registrados a não ser por uma coleta sistemática. Pelas características dos objetivos propostos neste projeto e pelo caráter inédito da maioria dos componentes de ambas as floras, o estudo está focado na análise de amostras já coletadas e disponíveis em diversas coleções. Como, em muitos casos, as peças são únicas, para melhor estudá-las, foi necessário pesquisar diferentes técnicas que pudessem trazer mais informações sem a sua destruição.

As atividades descritas a seguir, foram desenvolvidas numa ordem mais ou menos cronológica:

\subsubsection{Revisão bibliográfica}

A pesquisa bibliográfica foi realizada ao longo da elaboração da tese, através de consultas ao acervo da biblioteca do IGc/USP e aos sistemas de buscas de dados, fornecidos pelo Sistema Integrado de Bibliotecas da Universidade de São Paulo (SIBi/USP), incluindo as bases de dados DEDALUS, SciELO, ERL, ProBE e Web of Science, os periódicos eletrônicos disponíveis no site da Biblioteca do IGc USP e da 
CAPES, além do sistema de comutação bibliográfica COMUT. Foi consultado também o acervo físico da biblioteca da Universidad EAFIT (Colômbia), assim como suas bases de dados.

As linhas de pesquisa abordadas, foram as floras eocretáceas com ênfase naquelas da América do Sul, as gimnospermas da ordem Coniferales (fósseis e recentes), incluindo sua morfologia, anatomia, sistemática, distribuição geográfica, distribuição estratigráfica, relações evolutivas e implicações paleoambientais, e as histórias geológicas das áreas estudadas, assim como os diferentes métodos usados em paleobotânica.

\subsubsection{Métodos de campo}

Posto que o objetivo principal do estudo foi a avaliação taxonômica dos elementos do grupo das coníferas, e que o acesso aos níveis fossilíferos das duas unidades estudadas é, às vezes, fortuito, não foi possível fazer uma coleta sistemática de todos os elementos da paleoflora em termos de abundância de amostras e coleta exaustiva de dados tafonômicos. Contudo, o acervo da coleção depositada (própria ou obtida por empréstimo) no IGc/USP e das coleções visitadas, ofereceu abundantes fósseis atribuíveis às coníferas, que não haviam sido descritos anteriormente. 0 estabelecimento de um limite na quantidade de material a ser estudado, foi necessário para atingir o objetivo do projeto de Doutorado dentro do prazo estabelecido pelo Programa de Pós-graduação.

Apesar do anterior e com o intuito de melhor localização estratigráfica das amostras, observação de dados tafonômicos e aumento do número de espécimes estudados, foram feitas três viagens de campo, sendo duas para a Bacia do Araripe no Nordeste do Brasil e uma para a região de Villa de Leyva na Colombia. Nestas viagens foram reconhecidas as unidades detentoras dos fósseis estudados e outras associadas para o entendimento das histórias geológicas das áreas.

\subsubsection{Visitas técnicas e estágio}

Embora as áreas estudadas sejam reconhecidas pela abundância e diversidade de fitofósseis, eles não ocorrem em concentrações densas e sim espalhados em níveis 
raramente identificados. Outras vezes, o acesso às camadas produtivas nem sempre é possível devido às restrições das pedreiras ou porque a qualidade na preservação e beleza dos espécimes tem despertado o interesse de instituições nacionais, estrangeiras e particulares, levando muitos destes fósseis a serem comercializados como artigos exóticos. Resulta disso sua distribuição por muitas coleções científicas de instituições nacionais e estrangeiras e de particulares. Daí tornaram-se necessárias visitas a várias coleções onde sabe-se que há um importante acervo. A análise destas coleções apresenta importância principalmente do ponto de vista taxonômico, já que possuem espécimes em diferentes graus de preservação que se complementam, entretanto obedecem a coletas tendenciosas e sua posição estratigráfica dentro da formação é, geralmente desconhecida.

Durante a execução do projeto, foram realizadas visitas técnicas ás seguintes coleções estrangeiras:

Museum für Naturkunde der Humboldt-Universität, Berlim, tendo a colaboração da Dra. Barbara Mohr, quem atua como curadora da coleção de paleobotânica da instituição. Foram realizadas duas visitas a esta coleção, a primeira em 2008, durante a viagem para participar no 12th International Palynological Congress and 8th International Organisation of Palaeobotany Conference em Bonn, e a segunda durante o estágio de pesquisa realizado na mesma instituição. Nestas visitas foram examinados espécimes de Coniferales, Gnetales, Bennettitales, Cycadales, Caytoniales, Pteridospermales e táxons Incertae sedis de morfogêneros provavelmente relacionados a coníferas e outras gimnospermas. Espécimes de outros grupos, como Esfenófitas, Licófitas, Pteridófitas e Angiospermas, foram observados na coleção, mas não detalhadamente examinados.

Senckenberg Forschungsinstitut und Naturmuseum, Frankfurt, dirigida pelo Dr. Volker Wilde, diretor da seção de Paleobotânica deste museu. Nesta instituição foram realizadas duas visitas, a primeira em 2008 durante a viagem para participar no 12th International Palynological Congress and 8th International Organisation of Palaeobotany Conference em Bonn, e a segunda durante o estágio de pesquisa realizado no Museum für Naturkunde der Humboldt-Universität, Berlim. 0 acervo de fósseis da Formação Crato possui uma ampla variedade de coníferas e táxons de 
provável afinidade a este grupo. Foi examinado, atentamente, um exemplar (SM. B. 16447) classificado como do gênero Frenelopsis, em Kunzmann et al. (2006), com o objetivo de fazer comparações com espécimes semelhantes depositados na coleção científica do Laboratório de Paleontologia Sistemática do Instituto de Geociências da USP.

Senckenberg Naturhistorische Sammlungen, Dresden. Nesta instituição foram realizadas duas visitas, a primeira em 2008 durante a viagem para participar no 12th International Palynological Congress and 8th International Organisation of Palaeobotany Conference em Bonn, e a segunda durante o estágio de pesquisa realizado no Museum für Naturkunde der Humboldt-Universität, Berlim. Estas visitas foram orientadas pelo Dr. Lutz Kunzmann. Alí foram examinados exemplares de coníferas, representadas unicamente por duas espécies do gênero Brachyphyllum Na época da primeira visita, um outro exemplar (SM. B. 16486) classificado como do gênero Frenelopsis, em Kunzmann et al. (2006), pertencente ao Senckenberg Forschungsinstitut und Naturmuseum, Frankfurt, encontrava-se, por empréstimo nesta coleção. Assim como o exemplar de Frankfurt, foi examinado detalhadamente.

Coleção do Paleobotanical Herbarium da Ohio University (Athens, Ohio, Estados Unidos) e Laboratório do Dr. Gar Rothwell, na mesma instituição, foi orientada pela Dra. Gene Mapes. Esta visita consistiu na análise de espécimes de coníferas paleozóicas e mesozóicas de espécies já publicadas pelo grupo de trabalho dos Drs. Rothwell e Mapes, e no aprendizado, mediante um estágio de 3 semanas, de técnicas paleobotânicas adequadas para análise anatômica de fitofósseis.

Coleção paleobotânica do American Museum of Natural History - Smithsonian Institution (Washington D.C., Estados Unidos), orientada pelo curador Jon Wingerath. Nesta visita, foram analisados principalmente, ramos folhosos e cutículas de duas espécies de Pseudofrenelopsis, P. Parceramosa e P. varians, provenientes de localidades nos Estados Unidos e na Inglaterra, com o objetivo de comparar as suas características com os espécimes do mesmo gênero econtrados no Brasil e na Colômbia.

Coleção de paleobotânica do laboratório do Dr. Brian Axsmith na University of South Alabama (Mobile, Alabama, Estados Unidos), orientada pelo Dr. Axsmith. Neste laboratório, foram observados igualmente, espécimes do gênero Pseudofrenelopsis de 
duas localidades dos Estados Unidos. 0 objetivo desta visita, além da comparação dos ramos folhosos com espécimes já encontrados no Brasil e na Colômbia, foi a observação de estruturas reprodutivas, não encontradas, até agora, nas paleofloras onde se tem registro desse gênero na América do Sul, com o fim de facilitar a identificação de estruturas semelhantes no material estudado.

Coleção do Padre Huertas na Universidad Nacional de Colômbia, em Bogotá, Colômbia, para observação dos holótipos da paleoflora da Formação Paja descrita por Huertas $(1967,1970,1971,1976,2003)$.

As coleções do Museo Geológico José Royo y Gómez de Ingeominas, em Bogotá, do Museo El Fósil e do Museo Paleontológico de Villa de Leyva, em Villa de Leyva e da Coleção Botero na Universidad Nacional de Colômbia, em Medellin, todas na Colômbia, foram visitadas à procura de amostras adicionais da Formação Paja para análise, mas a quantidade de espécimes depositados nestes acervos era muito pequena, sem boa preservação ou acessível apenas para visitação.

A coleção da Universidad de Caldas, em Manizales na Colômbia, foi visitada e ali foram tomados por empréstimo alguns dos fósseis descritos nesta tese.

Foram também realizadas visitas técnicas às seguintes coleções nacionais:

A coleção científica do Instituto de Geociências da UFRJ (Universidade Federal do Rio de Janeiro), que foi orientada pelo Prof. Dr. Ismar de Souza Carvalho. Nesta coleção, foram examinados principalmente espécimes de coníferas da Formação Crato.

As coleções do Museu Paleontológico de Santana do Cariri da Universidade Regional do Cariri, em Santana do Cariri, CE, do Laboratório de Paleontologia da Universidade Regional do Cariri e do Museu dos Fósseis do DNPM, em Crato, CE, foram visitadas durante trabalho de campo em maio de 2010. Ali foi examinada a coleção por inteiro à procura de espécimes a serem incluídos numa análise mais detalhada para a qual foram tomados por empréstimo para uma análise mais acurada no Laboratórios de Paleobotânica e Palinologia do IGc/USP.

2.2.4. Métodos de laboratório

Os trabalhos laboratoriais começaram com a catalogação das amostras coletadas no campo, o que consistiu na numeração dos espécimes de acordo com os 
códigos utilizados no acervo das coleções de estudo e no seu cadastro, em livro de registro ou base de dados, com as informações de localização geográfica, idade e unidade litoestratigráfica de proveniência, coletor e uma avaliação preliminar de suas afinidades botânicas e/ou do tipo de órgão vegetal que representa. Algumas amostras, tomadas por empréstimo de outras coleções, não requiseram catalogação ou numeração. A seguir foram realizados reconhecimento e listagem preliminares das possíveis afinidades botânicas dos espécimes e do tipo de órgão fossilizado. Uma vez catalogadas as amostras, procedeu-se à preparação delas pelos métodos mais adequados conforme a sua preservação.

Outra parte importante do trabalho inicial de laboratório foi a identificação de assinaturas tafonômicas e diagenéticas das amostras em estudo.

Foram seguidas diversas técnicas, na maioria empíricas e consoantes às metas a serem atingidas, ao tipo de material fóssil e aos equipamentos disponíveis para sua preparação. Antes de pensar no método a ser empregado na preparação, foi importante definir o tipo de preservação fóssil: se tratava-se de restos incarbonizados, impressões, permineralizações, petrificações ou cimentações autigênicas, segundo a classificação de Schopf (1975). 0 tipo de preservação definiu a presença ou não de estruturas morfológicas ou anatômicas disponíveis para as análises. Dessa constatação, dependeram os procedimentos seguintes para obter a maior quantidade de informação possível do espécime.

\subsubsection{Preparação mecânica - Limpeza e degàgement}

Para observações da morfologia e mensurações, foram descobertas as partes do espécime fóssil ainda envolvidas pela matriz, desgastando os arredores, grão a grão, até o aparecimento do espécime fóssil completo e reduzindo o volume da amostra para um manuseio mais fácil. Para o desgaste da amostra foram utilizados martelete, talhadeira, agulha, instrumental odontológico e de joalheria, e pinceis delicados, para amostras mais resistentes foram usados martelo pneumático vibro graver e micro retífica. Estes procedimentos foram feitos sob o estereomicroscópio. Uma variante descrita por Fairon-Demaret et al. (1999) como dégagement, também utilizada, consiste na remoção de pequenos blocos e partículas de sedimento 
golpeando suavemente com martelo, uma mini-talhadeira ou agulha colocada sobre ele e orientada em ângulo adequado de modo que ao bater na ferramenta com o martelo, esta empurre os blocos em direção oposta ao fóssil, formando um ângulo agudo com ele, para não correr o risco de perfurá-lo. As partículas de poeira e blocos podem ser eliminadas com jato de ar suave, pêra de borracha ou sopro, tentando não atingir diretamente o fóssil. 0 dégagement não deve ser usado em espécimes muito frágeis. Nesse caso, é preferível usar a remoção grão a grão.

Quando se trata de espécimes extremamente frágeis, que podem se fragmentar ao remover o sedimento, recomenda-se o uso de alguma substância consolidante no sedimento, como polímero acrílico, acetato de vinil ou cianocrilato, ou a imersão do espécime em resina acrílica ou de poliéster.

\subsubsection{Preparação mecânica - Lâminas delgadas}

Este tipo de lâminas apresentam características muito semelhantes daquelas usadas em petrografia, sendo de grande utilidade no estudo anatômico de permineralizações e petrificações, de materiais translúcidos (e.g. sílica, calcita). Consiste basicamente no corte e polimento de superfícies até atingir uma espessura, o suficientemente fina, para as estruturas serem observadas sob luz transmitida (Taylor et al. 2009). É particularmente útil quando as paredes celulares foram total ou parcialmente substituídas por minerais ou não possuem suficiente matéria orgânica para serem feitos peels de acetato (Hass \& Rowe, 1999).

A confecção de lâminas delgadas começa pela escolha da orientação do corte de acordo com a amostra a ser analisada e as feições a serem observadas. Seguindo a técnica descrita em Taylor et al. (2009), o corte é feito com serra de aço de bordas diamantadas, e posteriormente, a superfície é polida com pó de carborundum até ficar lisa. Essa superfície é montada numa lâmina com alguma substância de inclusão (Bálsamo do Canadá, Entellan, Permount ou Eukit), na confecção de lâminas definitivas, ou com alguma resina termoplástica quando algum procedimento posterior, nessa superfície, é desejado. Uma vez que a substância de inclusão esteja seca, a amostra é submetida ao corte com serra diamantada para obtenção de lâminas delgadas da menor espessura possível. Depois a superfície continua sendo polida até 
atingir uma espessura observável sob o microscópio de luz transmitida, controlando para não desgastar, excessivamente, e perder as características celulares. No geral, as lâminas usadas em paleobotânica ficam com espessura maior do que as petrográficas, que são quase sempre de $30 \mu \mathrm{m}$. Uma vez pronta, a lâmina deve ser lavada e deixada a secar para depois ser fechada, com uma substância de inclusão e a lamínula. Quando se preferir não usar lamínula, as lâminas devem ser observadas no microscópio, usando óleo de imersão.

Bons exemplos do uso das lâminas delgadas em paleobotânica podem ser vistos nos estudos do Sílex Rhynie, do Devoniano da Escócia, onde uma grande variedade de plantas, além de animais, fungos e microorganismos foram preservados (e.g. Remy \& Hass, 1996; Krings et al. 2009); nos cones silicificados do Jurássico de Cerro Cuadrado da Argentina (e.g. Stockey, 1977) e nas madeiras silicificadas do Big Bend National Park, Estados Unidos (Wheeler \& Lehman, 2005).

A principal desvantagem desta técnica é que as serras usadas para corte possuem espessuras grandes, sendo muito destrutivas para amostras pequenas, não permitindo a realização de cortes seriados, muito úteis em análises anatômicas.

0 procedimento não foi adotado por ser altamente destrutivo devido à perda de material causada pela espessura das serras de corte em relação ao tamanho dos fósseis.

\subsubsection{Preparação mecânica - Peels de acetato}

Esta técnica foi introduzida por Walton (1928) para o estudo da anatomia de plantas fósseis contidas em coal balls. É necessária a preservação de material orgânico nas paredes celulares. Caso não tenham sido preservadas, devem-se realizar lâminas delgadas ou wafers.

A técnica, segundo Galtier \& Phillips (1999), consiste no corte e polimento com carborundum fino de uma superfície inicial a partir da qual começaria uma série. A superfície polida é atacada levemente com ácidos (clorídrico ou fluorídrico, dependendo da composição da permineralização) para desgastar um pouco o material mineral mais superficial e expor as paredes celulares (orgânicas). A amostra é delicadamente lavada é deixada para secar completamente. Assim que a amostra fica 
completamente seca, a superficie é colocada totalmente na horizontal e se aplica uma camada de acetona que a cobre completamente. Ato contínuo, é colocada a película fina de acetato de celulose, evitando a formação de bolhas e/ou rugas e se deixa secar. 0 tamanho da película de acetato deve ser maior do que a da superfície polida para facilitar o desprendimento após secagem. Obtido o peel, a superfície do fóssil é polida novamente e se repete o processo para obtenção dos peels seguintes até consumir o fóssil ou até completar a sequência desejada. Uma vez obtidos os peels, estes devem ser limpos no ácido para eliminar possíveis partículas minerais e, posteriormente, montados em lâminas com alguma substância de inclusão e cobertos com lamínulas para melhor observação no microscópio. Quando os peels forem armazenados sem montagem em lâmina, deve-se ter o cuidado de eliminar em cada peel suas bordas de acetato excedentes, que não fazem parte do fóssil, já que estas têm a tendência de se enrugar com o tempo.

A elaboração de peels de acetato têm a vantagem do aproveitamento quase integral da amostra e a realização de séries completas, sem perdas devidas à espessura das serras de corte como acontece com as lâminas delgadas e wafers.

A realização de seções seriadas de peels de acetato, que têm a vantagem do aproveitamento quase integral da amostra, como foi demonstrado em diferentes estudos anatômicos de coníferas (e.g. Rothwell, 1982; Mapes \& Rothwell, 1984; Hernández-Castillo et al. 2009) e Bennettitales (Stockey \& Rothwell, 2003), também não foi aplicável por ser um procedimento igualmente destrutivo e pela ausência de paredes celulares preservadas nas duas paleofloras estudadas nesta tese.

\subsubsection{Preparação mecânica - Wafers}

Para observação da anatomia interna de espécimes preservados em materiais não translúcidos como óxidos de ferro ou pirita, e que perderam totalmente as suas paredes celulares orgânicas, é usado o método de wafering (Hass \& Rowe, 1999). Esta técnica consiste em cortes seriados do material, que será previamente embebido em resina de poliéster ou acrílica para facilitar a sua manipulação e reduzir possíveis danos durante fatiamento. São cortadas fatias finas, de aproximadamente $2 \mathrm{~mm}$ de espessura, começando num dos extremos da amostra até consumí-la totalmente; essas 
fatias são chamadas de wafers. Depois do corte, as duas superfícies de cada fatia, são polidas com pó de carborundum. Após lavagem e secagem, são montadas em lâmina e cobertas com lamínula para observação com luz refletida. Para realçar o contraste e observar melhor a anatomia interna das amostras preservadas em óxidos de ferro, Rothwell (1982) atacou os wafers, depois de cortados e polidos, com uma solução saturada, quente, de ácido oxálico. Para fósseis piritizados, Kenrick (1999) recomenda a imersão dos wafers em ácido nítrico e, posteriormente, em hidróxido de sódio. Depois dos ataques químicos, as amostras devem ser lavadas delicadamente com água abundante e deixadas a secar antes de montar nas lâminas e cobrir com as lamínulas.

Este método foi testado em algumas amostras de caules da paleoflora da Formação Crato, mas não foi utilizado exaustivamente pelo, igualmente caráter destrutivo pela perda de material dada a espessura das serras de corte em relação ao tamanho dos fósseis, como acontece com as lâminas delgadas.

\subsubsection{Preparação mecânica - Cortes seriados}

A realização de cortes seriados por qualquer dos três métodos anteriores, pode ser de grande ajuda na interpretação da anatomia interna de fósseis ao permitir a observação das diferentes estruturas e sua organização, sendo usados também, para fazer reconstituições tridimensionais. Desafortunadamente, pelo caráter único da maioria dos espécimes e por serem emprestados de diversas instituições, não foi possível a aplicação dessas técnicas destrutivas massivamente para todos os espécimes estudados, sendo necessária a aplicação de técnicas de paleometria (Ver item 2.2.7.).

\subsubsection{Preparação química}

Cutículas fósseis de alguns poucos espécimes incarbonizados que ainda as continham, foram retiradas das amostras com ajuda de agulhas e preparadas com base na metodologia descrita em Dutra \& Stranz (2002). As cutículas foram inicialmente atacadas com ácido nítrico (HNO3) a 100\% por, aproximadamente, 24 horas e, posteriormente, com hidróxido de potássio $(\mathrm{KOH})$ a $10 \%$ diluído em água destilada, para eliminar a matéria orgânica morta ainda presente. Seguiu-se a lavagem 
com água destilada e a desidratação com álcool etílico. Algumas cutículas obtidas foram coloridas com solução alcoólica de safranina e montadas em lâmina coberta com lamínula para observação no microscópio óptico, enquanto outras, após secagem foram montadas em stubs para observações sob MEV (Microscópio Eletrônico de Varredura).

Outro tipo de preparação química consistiu na clarificação de material foliar de coníferas recentes para comparar as características das cutículas fósseis com as atuais. Esta preparação, baseada também em método descrito em Dutra \& Stranz (2002), consiste em mergulhar as folhas desidratadas em hidróxido de sódio $(\mathrm{NaOH})$ ou hidróxido de potássio $(\mathrm{KOH})$ a 10\% diluído em água destilada, aquecido por 5-10 minutos ou até elas adquirirem uma coloração amarronzada de aspecto translúcido. Após lavagem com água destilada, as folhas foram mergulhadas em hipoclorito de sódio, até ficarem transparentes. Posteriormente, foram tratadas com água destilada e desidratadas com álcool etílico. As folhas são coloridas com solução alcoólica de safranina e montadas com Entellan em lâmina coberta com lamínula, para observação no microscópio óptico.

\subsubsection{Métodos ópticos}

Os macrofósseis foram analisados sob estereomicroscópio ZEISS Stemi SV6, com câmara lúcida acoplada, do Laboratório de Paleobotânica do GSA-IGc/USP. A mensuração das feições morfológicas foi feita diretamente sobre o fóssil, ou sobre seus respectivos desenhos em escala, com paquímetro digital e régua.

A maior parte das fotomacrografias foram obtidas com câmera digital Canon EOS Rebel T2i de 18 megapixels de resolução. Para as fotomicrografias foi usada câmera digital Sony Cyber Shoot DSC-S75 de 3,3 megapixels de resolução, adaptada ao estereomicroscópio do Laboratório de Paleobotânica do GSA-IGc/USP, outras foram obtidas no Museum für Naturkunde der Humboldt-Universität, Berlim.

As cutículas e as lâminas foram examinadas sob microscópio óptico Carl Zeiss Axiophot II, do Laboratório de Paleobotânica do GSA-IGc/USP, e fotografadas com câmera digital Sony Cyber Shoot DSC-S75 de 3,3 megapixels de resolução, acoplada ao microscópio. 


\subsubsection{Microscopia eletrônica de varredura (MEV)}

Tendo em vista elucidar aspectos tafonômicos e taxonômicos, foram analisados, além das cutículas, estruturas tridimensionais preservadas em óxidos de ferro. Para isso, foram removidos pequenos fragmentos, e montados em stubs com fita de carbono ou cola e recobertos por ouro. Estas análises foram feitas em MEV Convencional LEO 440 I do Laboratório de Microscopia Electrônica de Varredura do IGc/USP, onde algumas amostras foram analisadas com espectrometria dispersiva de raio $\mathrm{X}$, para determinar composição qualitativa de algumas estruturas.

Uma das principais limitações do equipamento anterior foi o tamanho reduzido da amostra que pode ser analisada e na destruição da mesma devido ao recobrimento com ouro. Equipamentos de MEV ambiental permitiram a análise de amostras sem cobertura e em tamanhos maiores. Algumas amostras foram analisadas em JEOL JSM6490LV do Senckenberg Forschungsinstitut und Naturmuseum, Frankfurt, e outras em MEV JEOL JSM-6610LV do Museum für Naturkunde der Humboldt-Universität, em Berlim. Neste último, algumas das amostras foram recobertas com $\mathrm{Au}-\mathrm{Pd}$ para serem trabalhadas em alto vácuo visando conseguir dados de composição qualitativa.

\subsubsection{Tomografia e Microtomografia computadorizada}

Como alternativa de estudo da anatomia dos fósseis, sem destruição dos mesmos, foram testadas técnicas paleométricas como Tomografia e Microtomografia computadorizada em alguns espécimes.

As análises de tomografia computadorizada foram realizadas no Setor de Radiologia do Hospital Universitário da USP. Das amostras analisadas, somente algumas poucas se apresentaram informativas mediante esta técnica.

Duas amostras, uma proveniente da Formação Crato e outra da Formação Paja, foram analisadas por meio de microtomografia computadorizada no Museum für Naturkunde der Humboldt-Universität, em Berlim.

0 uso destas técnicas vem se tornando cada vez mais comum no estudo de vegetais fósseis e na paleontologia de um modo geral (DeVore et al. 2006; Friis et al. 2007; Sutton, 2008; Smith et al. 2009), devido ao caráter não invasivo nem destrutivo 
delas, possibilitando a observação de feições delicadas que ficariam destruídas na preparação da amostra ou durante a análise.

\subsubsection{Tratamento e interpretação dos dados}

Os espécimes analisados tiveram as suas características morfológicas e anatômicas comparadas com descrições, fotos e desenhos de outros fósseis encontrados na literatura paleobotânica e/ou de vegetais recentes. 0 objetivo destas comparações foi estabelecer as afinidades botânicas dos fósseis estudados e no caso de não corresponder a espécies anteriormente descritas, nomear conforme as regras do Código Internacional de Nomenclatura para algas, fungos e plantas (McNeill et al. 2012).

Quando as observações foram feitas diretamente sobre o fóssil com ajuda de estereomicroscópio ou sobre fotografias obtidas no MEV, não foi necessário processamento adicional. Entretanto, amostras analisadas com tomografia, as imagens obtidas necessitaram processamento, que foi realizado com o software Osirix versão 5.6.

Após a identificação taxonômica dos espécimes analisados, estes dados foram integrados para definir semelhanças e diferenças composicionais. Características como tipo de preservação dos fósseis e histórias geológicas das áreas de procedência dos mesmos, foram integradas ao cenário para tentar explicar as possíveis causas para essas semelhanças e/ou diferenças. 


\section{CAPÍTULO 3 - CONTEXTO GEOLÓGICO E CONTEÚDO FOSSILÍFERO}

3.1. Contexto geológico e paleoambiental da Formação Crato

Durante a fragmentação de Gondwana que resultou na separação da América do Sul e África e na implantação entre elas do Oceano Atlântico Sul, se originaram numerosas bacias sedimentares no nordeste do Brasil que hoje são encontradas tanto na margem quanto no interior do continente.

Dentre elas, a Bacia do Araripe foi originada pela reativação de antigas geofraturas pré-cambrianas (Ponte, 1996), evento conhecido para o Nordeste brasileiro como Reativação Vealdeniana (Almeida, 1967). Esta bacia tem forma alongada no sentido E-W, com $170 \mathrm{~km}$ de comprimento e até $50 \mathrm{~km}$ de largura, ocupando parte dos estados de Ceará, Pernambuco e Piauí, ocupando uma área de

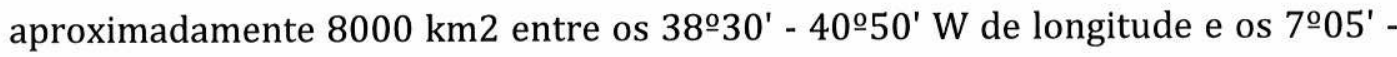
$7^{\circ} 50^{\prime} \mathrm{S}$ de latitude (Figura 3.1).

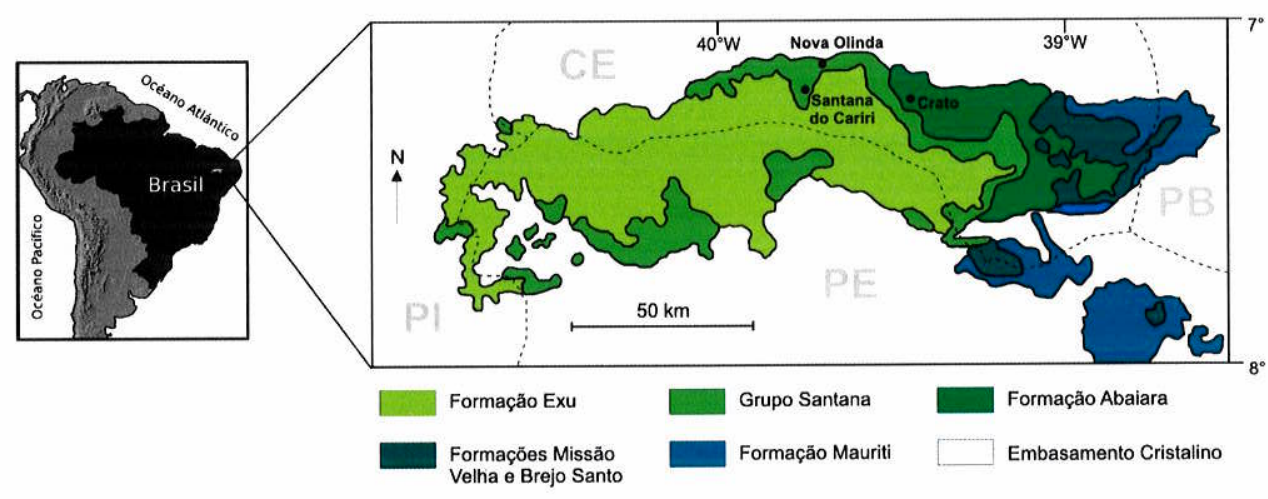

Figura 3.1. Localização da Bacia do Araripe no nordeste do Brasil e mapa geológico simplificado (Modificado de Neumann et al., 2003)

0 preenchimento sedimentar da Bacia do Araripe consiste em camadas de idade paleozoica e principalmente mesozoica repousando sobre um embasamento cristalino pré-cambriano. Estas camadas foram divididas em quatro tectonosequencias sucessivas (Ponte \& Ponte-Filho, 1996). Os sedimentos mesozoicos fazem parte das sequencias Pre-rifte, Syn-rifte e Pos-rifte. Esta ultima sequencia, depositada durante o Aptiano e Albiano, corresponde litologicamente ao Grupo 
Santana que inclui as Formações Rio da Batateira, Crato, Ipubi, Romualdo e Arajara na nomenclatura de (Neumann \& Cabrera, 1999). Segundo os mesmos autores, o ambiente de depositacão desta sequencia foi fluvio-lacustre a lacustre carbonático na sua fase inicial, passando a marinho raso e finalmente a ambiente transicional.

A Formação Crato (Figura 3.2) foi formada no final do Aptiano, e compõe-se de sequencias carbonáticas sucessivas intercaladas com siltitos e arenitos finos depositados num sistema lacustre que teria se estendido por um área de ate 7500 $\mathrm{km}^{2}$ no seu estagio final.

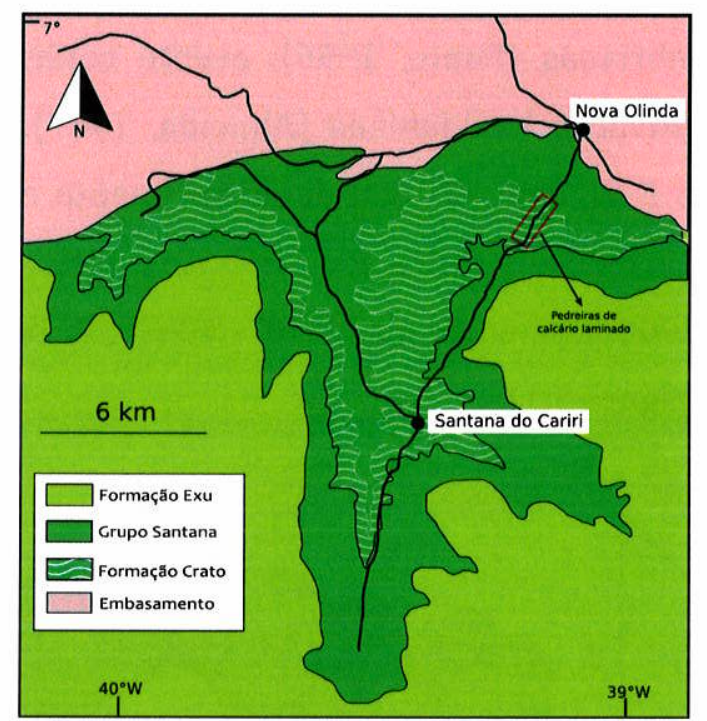

Figura 3.2. Mapa geológico da Formação Crato na área de procedência dos fósseis estudados (Modificado de Martill, 2007).

0 paleolago que teria dado origem à Formação Crato não deveria ter tido profundidade de mais de 20 metros e teria se desenvolvido sob um regime climático quente tropical a subtropical (Neumann et al., 2003). Heimhofer \& Martill (2007) indicam a presença de águas hipersalinas e anóxicas no fundo do lago, mas bem misturadas e produtivas na superfície. A presença de pseudomorfos de halita e a falta de indicadores de vida bentônica são apontadas como evidencias de aguas hipersalinas no fundo do lago (Neumann et al., 2003).

A idade neoaptiana da Formação Crato é baseada na Ostracozona de Cytheridea (NRT-011) e na Palinozona de Sergipea variverrucata (P-270), correspondente ao Andar Alagoas (Arai et al., 2001). Este andar foi calibrado com 
os andares internacionais, com base em eventos microflorísticos globais (Arai et al., 1989).

A Formação Crato é considerada como portadora de uma das biotas eocretáceas mais diversificadas e melhor preservadas (Figura 3.3), ganhando o status de Konservat Laggersttäte (Selden \& Nudds, 2005). Sua assembleia fossilífera contem abundantes restos de artrópodes, peixes e plantas. Macro e microfósseis de plantas incluem espécimes atribuídos a diferentes grupos incluindo pteridófitas, coníferas, gnetales e angiospermas.

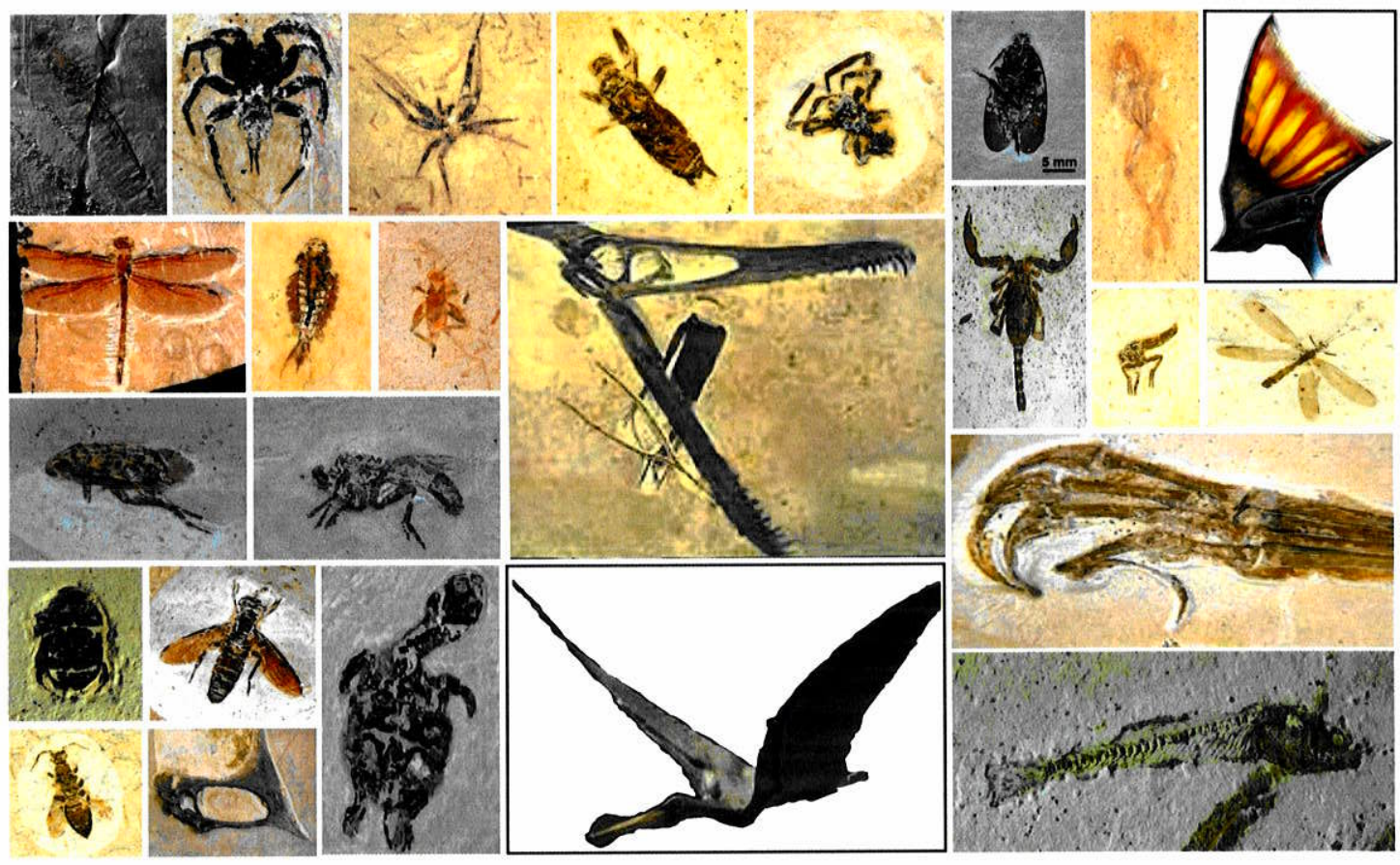

Figura 3.3. Mosaico de imagens da paleofauna da Formação Crato mostrando um pouco da sua diversidade e preservação.

\subsection{Estudos paleobotânicos prévios na Formação Crato}

$\mathrm{Na}$ flora da Formação Crato, tem sido encontrada uma grande variedade de macrofósseis vegetais, pertencentes às Esfenófitas, Licófitas, Filicófitas, Coníferas, Gnetales e Angiospermas. Esta paleoflora, apesar de sua excelente preservação, abundância, diversificação, posicionamento paleogeográfico na Província Florística Equatorial Árida e idade coincidente com a primeira diversificação das angiospermas, tem poucos estudos sistemáticos e praticamente nenhum estudo 
paleoecológico. A Tabela 3.1 mostra os táxons oficialmente descritos para a Formação Crato. Apesar de existir muitas outras formas já registradas, estas carecem de descrições formais aceitas pelo Código Internacional de Nomenclatura Botânica, visto terem sido publicadas apenas em resumos de eventos ou teses.

Tabela 3.1. Lista de macrofósseis descritos formalmente para a Formação Crato.

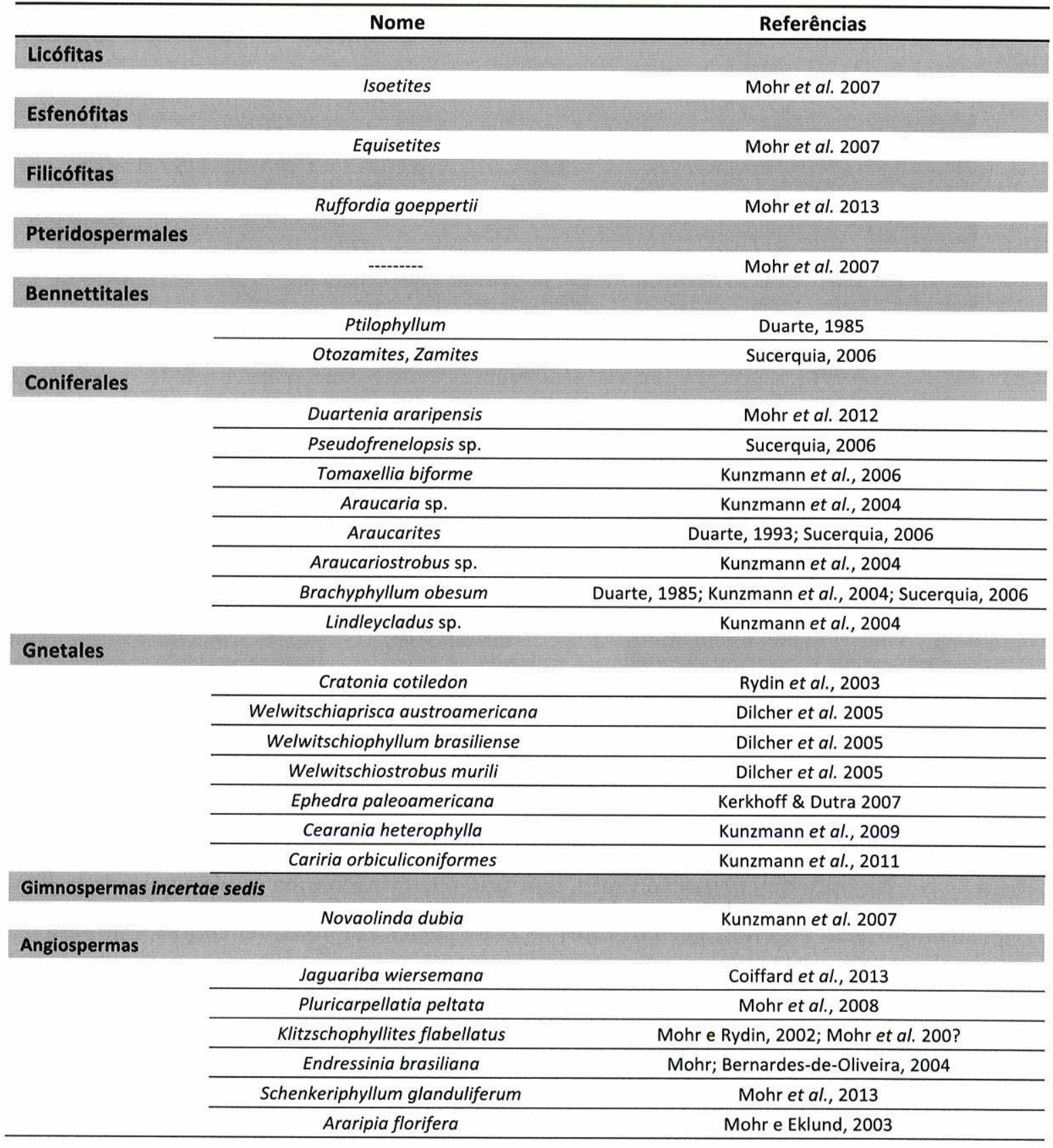




\subsection{Contexto geológico e paleoambiental da Formação Paja}

A evolução geológica da Colômbia envolve numerosas etapas de acresção, subducção e colisão como resultado da interação entre as placas Sul-americana, Nazca/Farallon e Caribe (Campos Alvarez \& Roser, 2007). Uma de suas feições fisiográficas mais representativas, a Cordilheira dos Andes, constitui uma das mais ativas regiões de geração de crosta continental do mundo, na qual adições verticais de magma e acresção de domínios intra-oceânicos são características comuns (e.g., Weber et al., 2002).

De forma geral, a Cordilheira dos Andes, na Colômbia, encontra-se subdividida geograficamente nas Cordilheiras Oriental, Central e Ocidental (Figura 3.4), sendo cada uma delas gerada por um evento diferente de acresção crustal. Estes limites geográficos coincidem com a subdivisão em províncias geológicas, Leste, Central e Oeste (Etayo-Serna et al., 1983), dos terrenos tectônicos que compõem a Colômbia

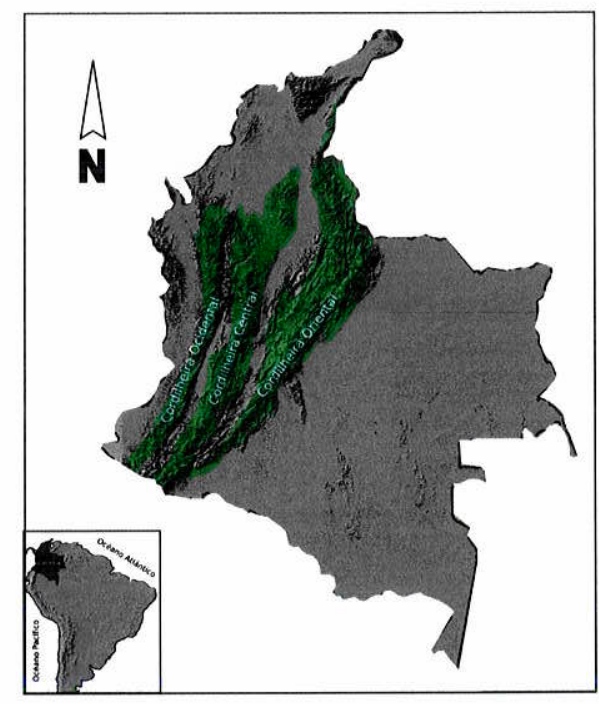

Figura 3.4. Mapa digital de terreno mostrando a subdivisão dos Andes Colombianos nas Cordilheiras Ocidental, Central e Oriental.

A Cordilheira Ocidental é composta por terrenos oceânicos, acrescidos à crosta continental principalmente no Cretáceo, e a Cordilheira Central é formada, em essência, pelo embasamento metamórfico, com rochas magmáticas associadas, e finas camadas de sedimentos de ocorrência local. A Cordillera Oriental da 
Colômbia é um cinturão dobrado que está composto por embasamento précambriano e paleozoico, coberto por uma espessa sequencia de rochas sedimentares mesozoicas e cenozoicas.

Para explicar a formação da Cordillera Oriental durante o MiocenoPlioceno, é aceito de um modo geral que houve inversão de duas bacias Neojurássicas-Eocretáceas: a Bacia Tablazo-Magdalena no oeste e a Bacia do Cocuy para leste (Figura 3.5). Estas bacias estariam separadas pelo Alto de Santander (Colletta et al., 1990; Dengo \& Covey, 1993; Cooper et al., 1995) e sua sedimentação teria começado com a formação de uma megasequencia sin-rifte associada ao proto-Caribe e relacionada à separação entre a a América do Norte e a do Sul (Cooper et al., 1995).

A sedimentação do Jurássico e Cretáceo da Cordilheira Oriental tem sido associada ao rifteamento responsável pela separação da América do Norte e do Sul mas também à extensão de backarc causada pelo soerguimento da Cordilheira Central, no processo de subducção da placa Farallón sob a placa Sulamericana (Maze, 1984; Fabre, 1987; Taboada et al., 2000).

Cooper et al. (1995) apresentam a sedimentação durante o Jurássico e Cretáceo da atual Cordilheira Oriental, no contexto de uma bacia de backarc subdividida em duas bacias paralelas, a do Tablazo-Magdalena e a do Cocuy, separadas pelo alto estrutural de Santander (Figura 3.5.). Esta sedimentação de backarc teria sido posterior a uma de rifte continental associada à separação da Américas do Norte e do Sul, como atestariam os sedimentos das formações Girón e Tambor da Bacia do Magdalena Medio (redbeds, arenitos, lamitos e conglomerados (Campos-Alvarez \& Roser, 2007; Cooper et al., 1995; Villamil et al., 1999), sotopostos aos arenitos e argilitos da Formação Cumbre, aos calcários da Formação Rosablanca e aos folhelhos pretos da Formação Paja.

A sequencia litológica da Formação Paja se compõe, predominantemente, por folhelhos pretos ricos em matéria orgânica, intercalados em menor quantidade com arenitos siltosos, folhelhos pretos, calcários, e, ocasionalmente, com lamitos verdes massivos pobres em matéria orgânica (Campos Alvarez \& Roser, 2007). Em direção ao topo da Formação Paja podem ser encontrados folhelhos com níveis de 
gesso (Toussaint, 1996). A espessura desta formação pode variar de 125 a $650 \mathrm{~m}$ (Royero and Clavijo, 2000).

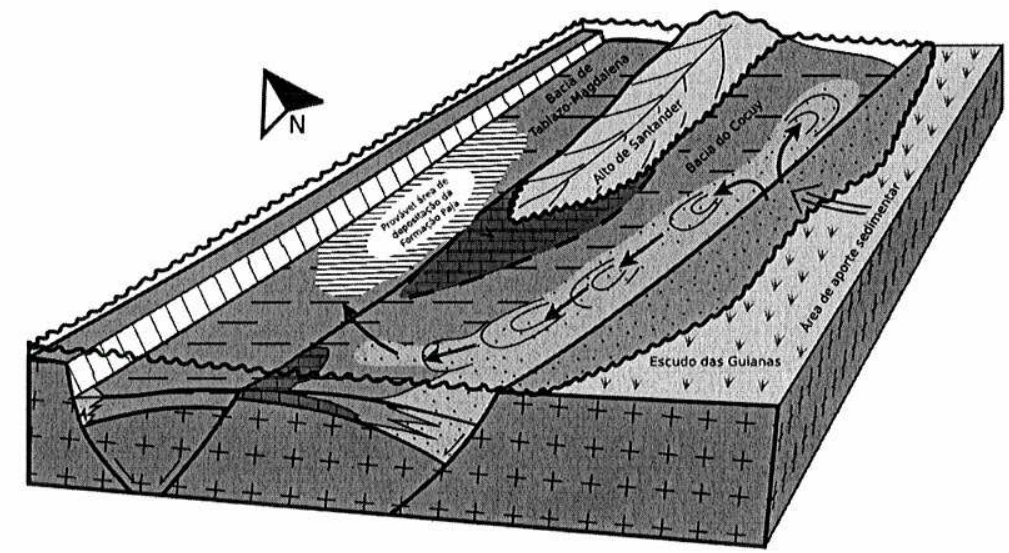

Figura 3.5. Bloco mostrando o provável ambiente de depositação da Formação Paja na Bacia do Tablazo-Magdalena, com proveniência de sedimentos do Escudo das Guianas (Modificado de Cooper et al., 1995 e Campos-Alvarez \& Roser, 2007).

A composição geoquímica dos folhelhos pretos da Formação Paja indicaria uma área intracratônica de proveniência dos sedimentos, provavelmente do Escudo das Guianas (Campos-Alvarez \& Roser, 2007), com sedimentos muito maduros, reciclados desta área tectonicamente estável. Esse fato indicaria uma posição não muito próxima do arco sendo a sua sedimentação mais relacionada a uma margem passiva.

\subsubsection{Estudos paleobotânicos prévios na Formação Paja}

0 primeiro registro de flora na Formação Paja (Berry, 1924) corresponde a uma semente de Anacardium encontrada perto do Monastério del Ecce Homo nos arredores do Município de Villa de Leyva.

Posteriormente, o Padre Huertas em seu trabalho Sertum florulae fossilis Villae de Leivae (Huertas, 1967, 1970, 1976), faz um primeiro compêndio taxonômico desta flora, complementado posteriormente por Waveren et al. (2002) e Huertas (2003). As espécies registradas são apresentadas na Tabela 3.2. e na sua maioria, são apenas registros sem muita discussão acerca de sua posição taxonômica. 
Tabela 3.2. Macrofitofósseis da Formação Paja

\begin{tabular}{|c|c|c|}
\hline & Nome & Referências \\
\hline \multicolumn{3}{|l|}{ Filicófitas } \\
\hline & Phlebopteris sp. & Pons, 1982a \\
\hline & Weichselia sp. & Pons, 1982a; Moreno, 1993 \\
\hline & Piazopteris branneri & Pons, 1982b \\
\hline & Paradoxopteris stromeri & Van Waveren et al., 2002 \\
\hline \multicolumn{3}{|l|}{ Pteridospermales } \\
\hline & Sagenopteris sp. & Pons, 1982b \\
\hline & Taeniopteris sp. & Van Waveren et al., 2002 \\
\hline \multicolumn{3}{|l|}{ Cycadales } \\
\hline & Macrotaeniopteris sp. & Van Waveren et al., 2002 \\
\hline & Nilssonia cf. $N$ orientalis & Huertas, 1970 \\
\hline & Nilssonia cf. N. princeps & Huertas, 1967 \\
\hline & Pseudoctenis sp. & Moreno, 1993 \\
\hline \multicolumn{3}{|l|}{ Bennettitales } \\
\hline & Zamites gigas & Pons, 1982a \\
\hline \multicolumn{3}{|l|}{ Coniferales } \\
\hline & Araucariostrobus archangelskii & Huertas, 1976 \\
\hline & Araucariostrobus cf. A. archangelskii & Van Waveren et al., 2002 \\
\hline & Araucariostrobus brievanus & Huertas, 2003 \\
\hline & Araucariostrobus camargoi & Huertas, 1970 \\
\hline & Araucariostrobus carmenii & Huertas, 2003 \\
\hline & Araucariostrobus creutzbergi & Huertas, 1970; Van Waveren et al., 2002 \\
\hline & Araucariostrobus gracilis & Huertas, 2003 \\
\hline & Araucariostrobus protectus & Huertas, 2003 \\
\hline & Araucariostrobus signatus & Huertas, 2003 \\
\hline & Brachyphyllum winklerprinsi & Van Waveren et al., 2002 \\
\hline & Brachyphyllum sp & Pons, 1982b; Van Waveren et al., 2002 \\
\hline & Cupressinocladus hoedemaekeri & Van Waveren et al., 2002 \\
\hline & Cupressinocladus leivanum & Huertas, 1970; Van Waveren et al., 2002 \\
\hline & Cupressinocladus lepidophyllus & Van Waveren et al., 2002 \\
\hline & Cupressinocladus pompeckji & Pons, 1982a \\
\hline & Cupressinocladus cf. C. pompeckji & Moreno, 1993 \\
\hline & Cupressinocladus leptocladoides & Pons, 1982a \\
\hline & Cupressinocladus sp. & Moreno, 1993; Van Waveren et al., 2002 \\
\hline & Damarites acostae & Huertas, 2003 \\
\hline & Damarites carmelitanus & Huertas, 2003 \\
\hline & Damarites conicus & Huertas, 2003 \\
\hline & Damarites kucii & Huertas, 2003 \\
\hline & Damarites yarzenii & Huertas, 1976 \\
\hline & Damarophyllum associatum & Huertas, 2003 \\
\hline & Damarophyllum speciosum & Huertas, 2003 \\
\hline & Juniperites monospermus & Huertas, 2003 \\
\hline & Pagiophyllum sp & Van Waveren et al., 2002 \\
\hline
\end{tabular}




\begin{tabular}{cc}
\hline Pinostrobus caldasii & Huertas, 2003 \\
\hline Pityostrobus botero-arangoi & Huertas, 2003 \\
\hline Pityostrobus idroboi & Huertas, 2003 \\
\hline Pityostrobus leyvae & Huertas, 2003 \\
\hline Pityostrobus sanctieccehomensis & Huertas, 1967; Van Waveren et al., 2002 \\
\hline Podozamites cf. P. lanceolatus & Huertas, 1967 \\
\hline Podozamites sp & Pons, 1982a; Moreno, 1993; Van Waveren et al., 2002 \\
\hline Protophyllocladoxylon rosablancaense & Pons, 1971 \\
\hline Protophyllocladoxylon sp & Pons, 1982b \\
\hline Thuites venustus & Huertas, 1967
\end{tabular}

\begin{tabular}{cc} 
Carpolithes deltoideus & Huertas, 2003 \\
\hline Carpolithes incertus & Huertas, 2003 \\
\hline Carpolithes perturbatrix & Huertas, 2003 \\
\hline Carpolithes stigmatus & Huertas, 2003 \\
\hline Carpolithes sp. & Huertas, 2003 \\
\hline Dycotylophyllum spatulatum & Pons, 1982a; Moreno, 1993 $1982 \mathrm{a}$ \\
\hline Dycotylophyllum sp. & Moreno, 1993 \\
\hline Cinnamonoides sp. & Huertas, 1967 \\
\hline Ficus cf. F. ceratops & Pons, 1982a \\
\hline Monocotylophyllum heterophyllum & Huertas, 2003 \\
\hline Passifloraecarpus uribei & Huertas, 2003 \\
\hline Perseaspermum pintoanum & Huertas, 1967 \\
\hline Sterculiocarpus etayoi & Huertas, 2003 \\
\hline Sterculiocarpus jaramilloi & Huertas, 2003 \\
\hline Sterculiocarpus lunatus & Van Waveren et al., 2002 \\
\hline cf. Sterculiocarpus sp. & Huertas, 2003 \\
\hline Theobroma verum &
\end{tabular}




\section{CAPÍTULO 4 - RESULTADOS E DISCUSSÕES}

\subsection{Avaliação taxonômica}

A concordância sobre os nomes dos organismos é importante para se manter uma comunicação científica efetiva, que somente pode se atingir se existem e são cumpridas as regras internacionais que governem essas denominações.

Desde sua criação em 1950, a Organização Internacional de Taxonomia de Plantas (IAPT) é o organismo encarregado de estabelecer as regras para designação de plantas tanto viventes como fosseis, através do Código Internacional de Nomenclatura para algas, fungos e plantas (ICN), anteriormente conhecido como Código Internacional de Nomenclatura Botânica (ICBN). Na sua versão mais recente, o Código de Melbourne (McNeill et al. 2012), adotado durante o 18o Congresso Internacional de Botânica, na Cidade de Melbourne, Austrália, em julho de 2011, foram mudadas algumas regras para designação de vegetais fósseis.

É importante ressaltar aqui, que a principal mudança do ICBN para o ICN, referente à paleobotânica, foi a eliminação do conceito de "morfotaxon" para a designação de fragmentos de plantas fósseis, adotando-se para isto o uso do termo "táxon fóssil", anteriormente usado para a reconstrução hipotética da planta, baseada nesses fragmentos. Fica então, o táxon fóssil como um táxon cujo nome tem base num tipo fóssil, sendo que este fóssil pode ser um fragmento, estágio ontogenético ou preservacional de uma planta, tornando desnecessária a utilização do termo "morfotaxon".

Tanto para táxons fósseis como para os não fósseis, a sistemática estabelece uma organização natural, baseada em relações evolutivas verdadeiras, identificando linhagens de organismos ou clados que, independentemente, de outros, atingiram alguma vantagem evolutiva.

A sistemática paleobotânica segue as mesmas regras da sistemática botânica. A única diferença entre elas é o material no qual se baseiam os nomes, que no caso de ser fóssil podem estar preservados de modo fragmentar, geralmente, como órgãos isolados ou fragmentos deles e, excepcionalmente, órgãos em conexão orgânica. 
As categorias taxonômicas superiores, usadas na classificação dos exemplares estudados no presente trabalho, são as do esquema proposto por Stewart \& Rothwell (1993). Para a classificação das famílias da Ordem Coniferales seguiu-se a proposta de Taylor et al. (2009).

A Ordem Coniferales inclui, atualmente, tanto plantas de porte enorme como também plantas arbustivas, com muitas espécies cujos indivíduos são de longa vida podendo chegar até os 5000 anos. Considerada como um grupo monofilético composto pelas famílias Pinaceae, Podocarpaceae, Araucariaceae, Taxaceae, Cephalotaxaceae, Sciadopytiaceae e Cupressaceae (Stefanović et al., 1998), esta ordem possui na atualidade ao redor de 650 espécies distribuídas em 60 gêneros (Taylor et al., 2009).

Segundo Archangelsky (1970), a principal característica que agrupa os componentes desta ordem é a presença de megaestróbilos compostos ou cones que consistem em um eixo central portando em filotaxia espiralada ou decussada, escamas e brácteas parcial ou totalmente soldadas protegendo as sementes. Apesar de não ser comum a todas as coníferas, a grande maioria apresenta este tipo de cone feminino. Os cones masculinos são simples, com os microesporófilos em arranjo filotáxico helicoidal, com os sacos polínicos situados na superfície abaxial (Taylor et al. 2009). $\mathrm{Na}$ anatomia de partes vegetativas, as coníferas também podem ter características que as diferenciam de outros grupos mas que não chegam a ser exclusivos para elas, os autores acima citados ressaltam o lenho picnoxílico com pontuações circulares areoladas, cutículas espessas e estômatos haplocélicos.

A origem das coníferas remonta ao Pennsilvaniano, que são consideradas como derivadas das Cordaitales, o que seria sugerido pela estrutura dos megaestróblos compostos que teriam evoluído a partir das unidades reprodutivas desse grupo por redução de ramos curtos até constituir as brácteas (Taylor et al., 2009). Assim a ordem Coniferales poderia ser considerada monofilética como comprovado por Stefanovic et al. (1998), embora Bowe et al. (2000) e Chaw et al. (2000) não considerem as coníferas monofiléticas, baseados no clado formado por Gnetales e Pinaceae obtido a partir de análises moleculares e que seria o grupo irmão do restante das coníferas. 
No desenvolvimento desta tese, a sistemática das coníferas da paleoflora da Formação Crato (Brasil) como a da paleoflora da Formação Paja (Colômbia) tem sido tratada em diferentes níveis de profundidade devido a dois motivos principais: a) a preservação do material não é de qualidade ou grau homogêneo, isto é, há peças melhor preservadas, que auxiliam na interpretação morfológica e anatômica, enquanto outras oferecem menos detalhes morfológicos; b) a quantidade e diversidade do material que foi tornando-se, gradualmente, disponível a medida que as coleções iam sendo visitadas, acabou impedindo o tom igualmente profundo dado aos primeiros táxons tratados, exigindo mais tempo para pesquisa, que será realizada em novas oportunidades.

A avaliação taxonômica dos espécimes observados é apresentada a seguir nas Tabelas 4.1 e 4.2 .

Tabela 4.1. Coníferas fósseis da Formação Crato

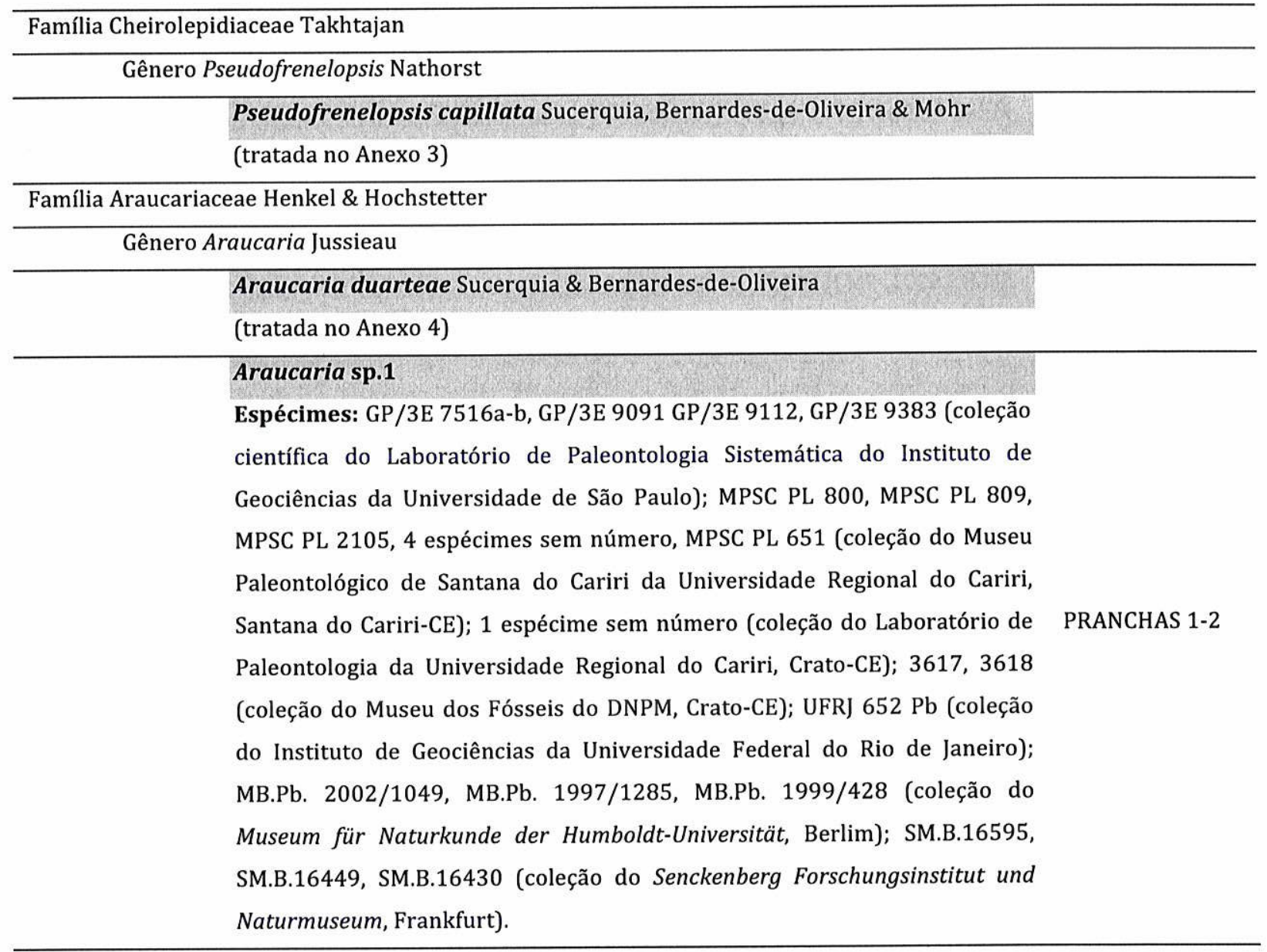




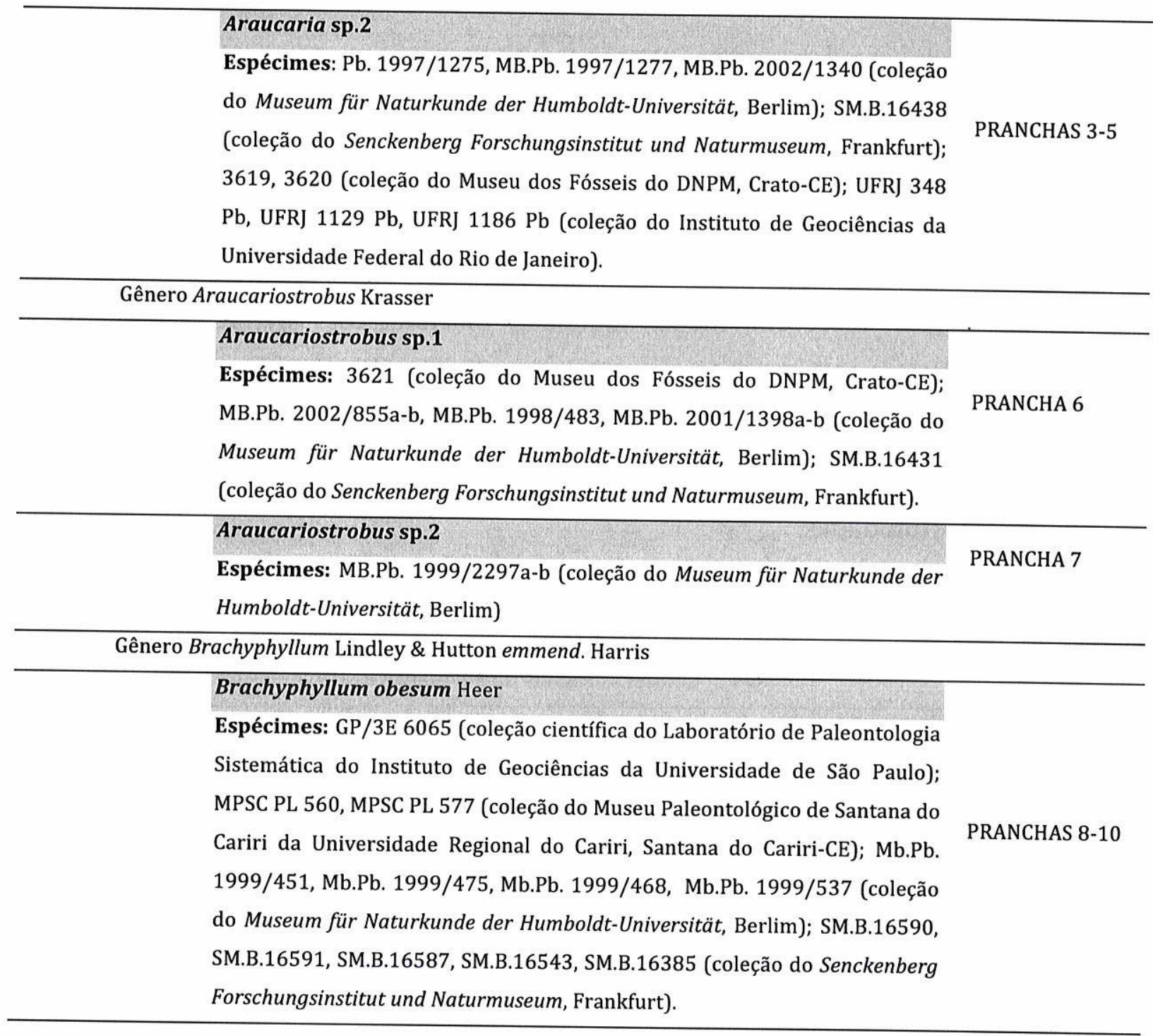

Tabela 4.2. Coníferas fósseis da Formação Paja

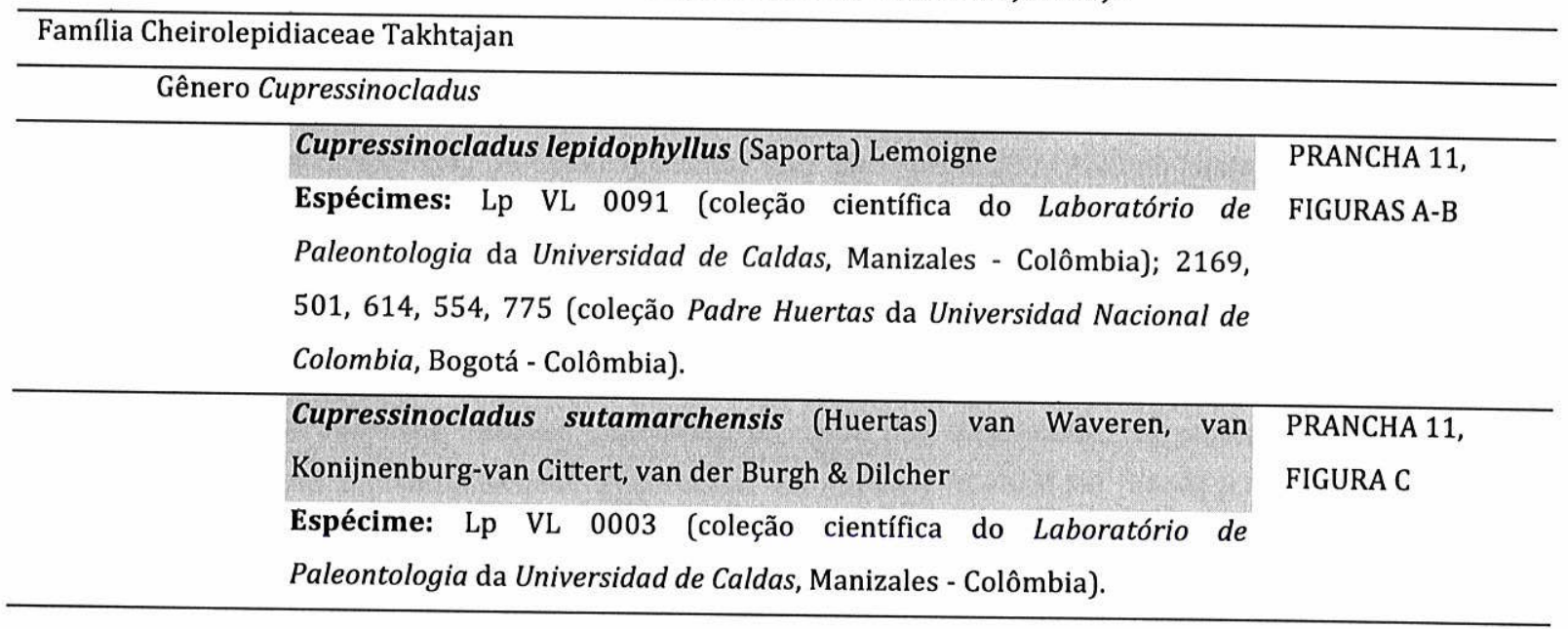




\begin{tabular}{|c|c|c|}
\hline \multicolumn{3}{|c|}{ Gênero Frenelopsis Schenk emmend. Watson } \\
\hline & Frenelopsis sp. & PRANCHA 11, \\
\hline & $\begin{array}{l}\text { Espécimes: Lp VL 0002, Lp VL 0005, Lp VL } 0016 \text { (coleção científica do } \\
\text { Laboratório de Paleontologia da Universidad de Caldas, Manizales - } \\
\text { Colômbia). }\end{array}$ & FIGURA D \\
\hline \multicolumn{3}{|c|}{ Gênero Pseudofrenelopsis Nathorst } \\
\hline & Pseudofrenelopsis sp. & PRANCHA 11, \\
\hline & $\begin{array}{l}\text { Espécimes: Lp VL 0001, Lp VL 0009, Lp VL 0010, Lp VL } 0022 \text { (coleção } \\
\text { científica do Laboratório de Paleontologia da Universidad de Caldas, } \\
\text { Manizales - Colômbia). }\end{array}$ & FIGURA E \\
\hline \multicolumn{3}{|c|}{ Família Araucariaceae Henkel \& Hochstetter } \\
\hline \multicolumn{3}{|c|}{ Gênero Araucariostrobus Krasser } \\
\hline & Araucariostrobus creutzbergi Huertas & PRANCHA 12, \\
\hline & $\begin{array}{l}\text { Espécimes: Lp VL } 0035 \text { (coleção científica do Laboratório de } \\
\text { Paleontologia da Universidad de Caldas, Manizales - Colômbia); } 2082 \\
\text { (coleção Padre Huertas da Universidad Nacional de Colombia, Bogotá - } \\
\text { Colômbia). }\end{array}$ & FIGURAS A-B \\
\hline & Araucariostrobus camargoi Huertas & PRANCHA 12, \\
\hline & $\begin{array}{l}\text { Espécimes: Lp VL } 0007 \text { (coleção científica do Laboratório de } \\
\text { Paleontologia da Universidad de Caldas, Manizales - Colômbia); } 180 \\
\text { (coleção Padre Huertas da Universidad Nacional de Colombia, Bogotá - } \\
\text { Colômbia). }\end{array}$ & FIGURAS C-D \\
\hline & Araucariostrobus signatus Huertas & PRANCHA 13, \\
\hline & $\begin{array}{l}\text { Espécimes: Mb.Pb. 2004/0401 (coleção do Museum für Naturkunde der } \\
\text { Humboldt-Universität, Berlim); Lp VL } 0051 \text { (coleção científica do } \\
\text { Laboratório de Paleontologia da Universidad de Caldas, Manizales - } \\
\text { Colômbia); 451, 452, } 766 \text { (coleção Padre Huertas da Universidad } \\
\text { Nacional de Colombia, Bogotá - Colômbia). }\end{array}$ & FIGURAS A-D \\
\hline \multicolumn{3}{|c|}{ Gênero Carpolithes } \\
\hline & Carpolithes sp. & PRANCHA 13, \\
\hline & $\begin{array}{l}\text { Espécimes: Lp VL } 0038 \text { (coleção científica do Laboratório de } \\
\text { Paleontologia da Universidad de Caldas, Manizales - Colômbia); 510, 584, } \\
\text { 596, 597, 628, } 655 \text { (coleção Padre Huertas da Universidad Nacional de } \\
\text { Colombia, Bogotá - Colômbia). }\end{array}$ & FIGURAS E-G \\
\hline
\end{tabular}

Foi possível confirmar que, pelo menos, duas famílias de coníferas estavam presentes em ambas as paleofloras: Cheirolepidiaceae e Araucariaceae. Alguns gêneros em comum podem ser achados: Pseudofrenelopsis, Araucariostrobus, com 
possibilidade de serem muitos mais elementos compartilhados assim que a taxonomia das duas paleofloras ficar melhor resolvida.

A Família Cheirolepidiaceae se representa na Formação Crato pela espécie Pseudofrenelopsis capillata (vide Anexo 3) e na Formação Paja pelos gêneros Cupressinocladus, Frenelopsis e Pseudofrenelopsis. Estruturas reprodutivas desta família não tem sido reconhecidas até o momento, embora existam espécimes suspeitos de pertencer á família, exigindo um estudo mais detalhado.

0 gênero Brachyphyllum, muitas vezes considerado pertencente à Família Cheirolepidiaceae e que é reportado em ambas as paleofloras (Kunzmann et al., 2004; Huertas, 2003), é considerado para a Formação Crato, como pertencente à Família Araucariaceae com base na espécie Brachyphyllum obesum, analisada neste trabalho. Brachyphyllum leivanum Huertas (1970) foi posteriormente recombinado no gênero Cupressinocladus (van Waveren et al., 2003).

A Família Araucariaceae compreende a maioria dos componentes das duas paleofloras. Na Formação Crato ocorrem os gêneros Araucaria, Araucariostrobus e Brachyphyllum, na forma de ramos folhosos, complexos bráctea-escama, cones masculinos e femininos. A Formação Paja exibe os mesmos tipos de fragmentos e praticamente os mesmos gêneros exceto o gênero Carpolithes inicialmente sem afinidade ou relacionado às angiospermas mas que apresenta uma clara semelhança com complexos bráctea-escama de Araucariaceae.

A espécie Araucaria duarteae que ocorre na forma de complexos brácteaescama destacados, se encontra morfologicamente mais relacionada com a seção Eutacta do mesmo gênero. As espécies Araucaria sp. 1 e Araucaria sp. 2 são consideradas aqui como megaestróbilos com afinidade a esse gênero pela presença de complexos bráctea-escama dispostos em filotaxia helicoidal e com uma única semente em cada complexo. Existe uma grande semelhança entre os complexos brácteaescama destacados de Araucaria duarteae e aqueles em conexão com Araucaria sp. 1, mas uma afinidade certa precisa ainda ser confirmada. A espécie Araucariostrobus creutzbergi apresenta as mesmas características que os cones anteriores, mas foi preservado o nome original, ressaltando que é necessário revisar a sua nomenclatura. 
As espécies correspondentes aos cones masculinos foram identificadas como tais pela presença de microesporófilos inseridos em filotaxia helicoidal a um eixo central como no caso de Araucariostrobus sp. 1, Araucariostrobus camargoi e Araucariostrobus signatus. Araucariostrobus sp. 2 foi considerado microestróbilo por sua morfologia e pela presença de grãos de pólen in situ.

Outras espécies de coníferas representadas por folhas, cones masculinos e femininos foram descritos anteriormente para as duas paleofloras. Na Formação Crato, Kunzmann et al. (2004) registram um cone masculino de Araucariostrobus sp. e Kunzmann et al. (2006) classificam ramos folhosos como pertencentes ao gênero Tomaxellia. Para a Formação Paja foram criadas numerosas espécies de cones masculinos e femininos (Huertas, 1967, 1976, 2003) que precisam de revisão detalhada já que algumas das formas apresentam muita semelhança entre si e algumas poderiam não fazer parte do grupo das coníferas. Como acontece com ramos folhosos de Cupressinocladus lepidophyllus que foram chamados Thuites venustus (Huertas, 1967) e Thuites frequens (Huertas, 2003), mas que para a autora consituem o mesma espécie.

\subsection{Modos de preservação}

Entende-se como tafonomia o estudo dos processos ocorridos entre a morte do organismo e o momento de coleta do fóssil (Holz \& Simões, 2002). Muitos desses processos são inferidos a partir de observações de campo. Devido ao fato da maioria dos fósseis disponíveis para o estudo ser proveniente de coleções existentes em instituições de ensino ou museus, existe uma tendência quanto à composição da flora e a qualidade de preservação desta. Apesar disso, algumas informações podem ser extraídas dos próprios fósseis.

0 entendimento dos processos tafonômicos, que deram origem às assembléias fitofossilíferas, pode fornecer pistas acerca das características paleoambientais, e elas ajudam a entender melhor os processos de fossilização das plantas.

A paleoflora das duas formações apresenta diversos tipos de preservação. $\mathrm{Na}$ Formação Crato as plantas fósseis são encontradas principalmente na forma de óxidos de ferro (visto em detalhe a seguir), pirita, incarbonizações, charcoal e impressões. 
Na Formação Paja, os fósseis de plantas são encontrados em concreções como petrificações, com preservação de algumas feições anatômicas porém sem parede celular ou como moldes internos e externos sem preservação anatômica.

Por disponibilidade e qualidade de informações, foi estudada em detalhe a preservação em óxidos de ferro das plantas fósseis da Formação Crato, os resultados aqui apresentados farão parte de uma publicação posterior.

4.2.1. Preservação celular em óxidos de ferro em plantas fósseis da Formação Crato

A Formação Crato é composta, principalmente, por calcários milimetricamente laminados, de ambiente lacustre, desenvolvidos sob condições climáticas tropicais áridas a semi-áridas, com longos intervalos de tempo seco e precipitação periódica. As condições paleoecológicas propostas para o lago, que deu origem à Formação Crato, são as de um corpo de água estratificado com águas doces ou salobras na superfície e hipersalinas e, possivelmente, anóxicas no fundo (Martill, 1993; Neumann, 1999; Heimhofer \& Martill, 2007).

A presença de órgãos vegetais em conexão orgânica, chegando às vezes à forma de plantas completas incluindo raízes, com boa preservação de detalhes morfológicos, sugere que o transporte, desde o lugar de crescimento até o de deposição, foi curto para alguns taxa, enquanto o caráter fragmentado e parcialmente deteriorado de outros fósseis pode indicar um transporte mais longo. Para estes, foi sugerido transporte por fluxos pluviais episódicos, típicos de climas mais secos.

Os macrofitofósseis da Formação Crato apresentam como tipo de preseervação frequente, moldes em óxidos de ferro (Figura 4.1). Exame de raio X realizado em ramos folhosos de coníferas, identificam o material dos moldes como limonita/goethita. Outros tipos de preservação são incarbonizações e impressões. 

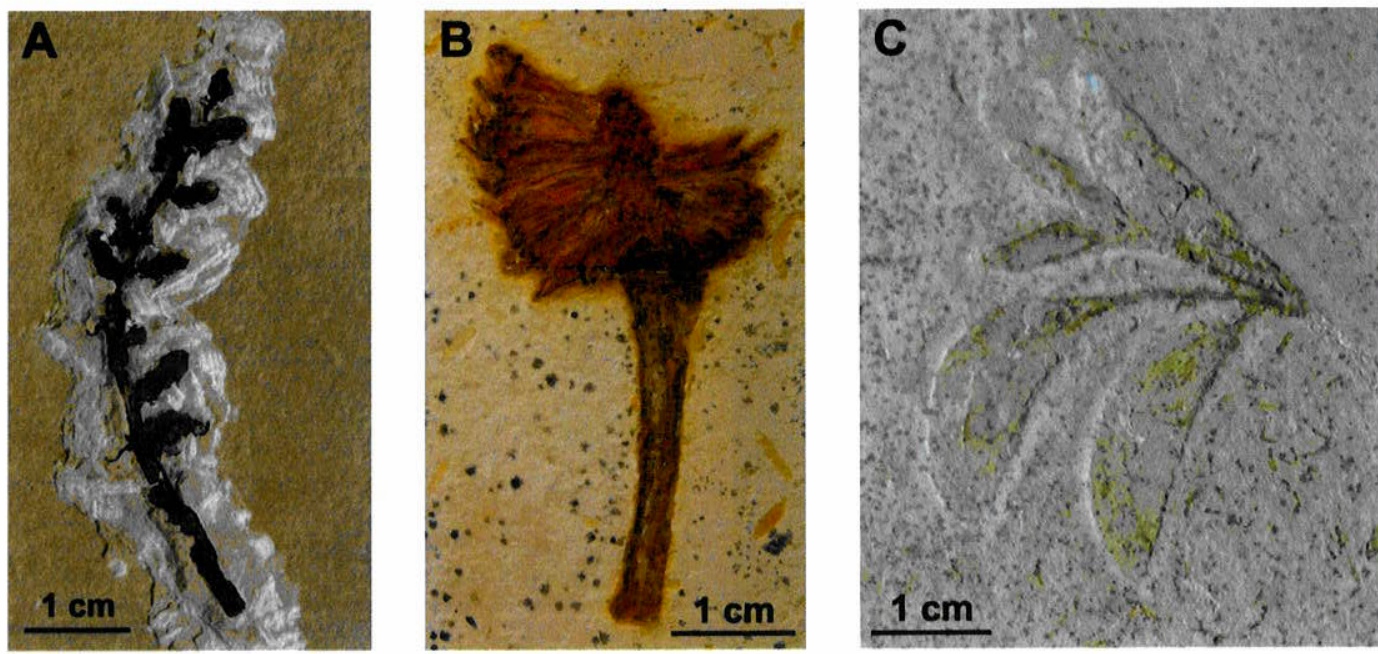

Figura 4.1. Tipos de preservação dos macrofitofósseis da Formação Crato. A. Eixo com estróbilos masculinos de conífera preservado como incarbonização (Amostra SM.B.16316). B. Estróbilo feminino de conífera preservado em óxidos de ferro pelo processo de cimentação autigênica (Amostra SM.B.16431). C. Ramo folhoso de gimnosperma preservada como impressão (Amostra CPCM 16).

Os restos incarbonizados, embora escassos, às vezes, permitem a recuperação de cutículas que, analisadas sob microscópio óptico, acrescentam detalhes da epiderme não observáveis nas amostras preservadas em óxidos de ferro. Poderia corresponder a fases mais anóxicas do fundo do lago, quando o material orgânico não seria decomposto e sim posteriormente, destilado durante os processos diagenéticos.

A preservação em óxidos de ferro corresponde a um processo de cimentação autigênica (Schopf, 1975). Neste processo, são criados moldes (externo e interno) (Figura 4.2A) que reproduzem, tridimensionalmente, as feições celulares do organismo. Posteriormente, pode ou não ocorrer preenchimento do interior das células (Figura 4.2B). Os tecidos vegetais, preservados em óxidos de ferro (limonita/goethita), apresentam finos detalhes anatômicos observáveis principalmente sob MEV, que são importantes no estabelecimento de afinidades taxonômicas e de características paleoecológicas e paleoclimáticas. 0 processo de cimentação autigênica deve ocorrer no início do soterramento do vegetal, para evitar o colapso das estruturas celulares e dos órgãos na posterior degradação do material original. 

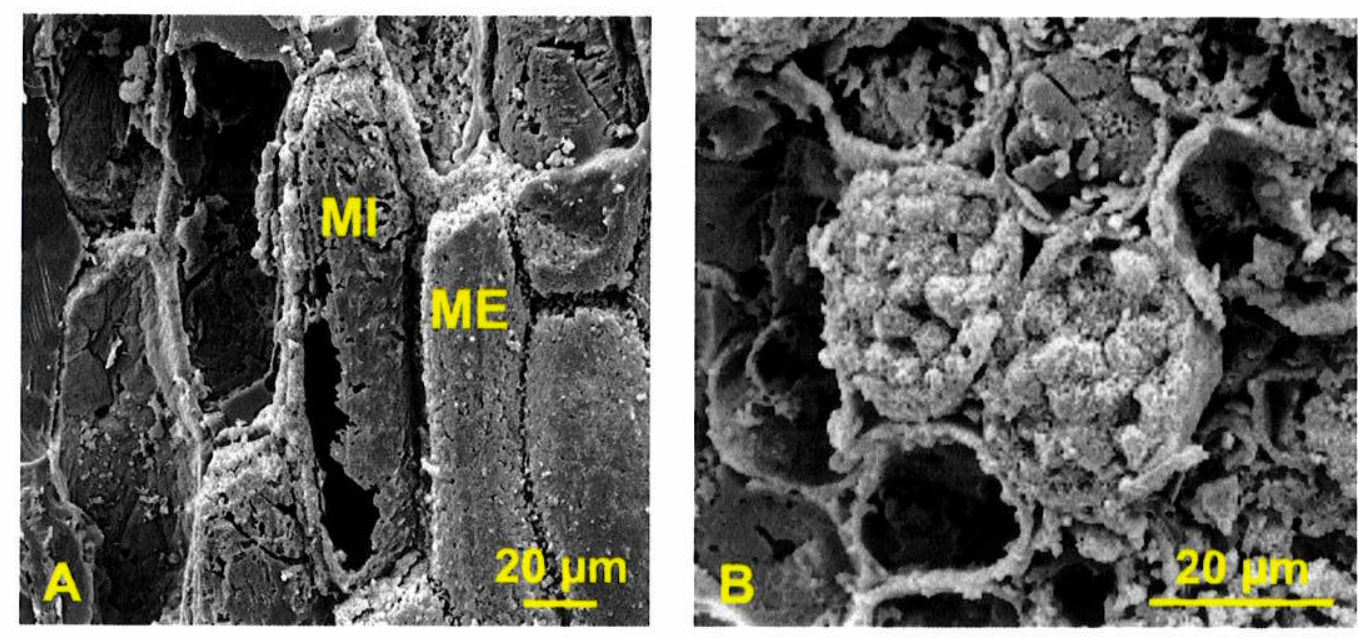

Figura 4.2. Preservação em óxidos de ferro pelo processo de cimentação autigênica em fósseis da Formação Crato. A. Criação de molde externo (ME) e molde interno (MI) (Fotografia extraída de Fanton, 2007). B. Preenchimento cristalino de espaços celulares (Fotografia extraída de Sucerquia, 2006).

Por consenso geral, o processo de fossilização dos macrofitofósseis da Formação Crato foi rápido o suficiente para permitir a preservação tridimensional de detalhes como estômatos, células epidérmicas, pontuações e espessamentos em traqueídes, vasos, células parenquimáticas, pontos de inserção de pelos e papilas (Figura 4.3).

Até o momento, não foi possível evidenciar se os óxidos de ferro, que constituem atualmente os fósseis, são de origem primária (Maisey, 1991) ou se estes fósseis foram inicialmente piritizados e posteriormente oxidados (Martill, 1993). 

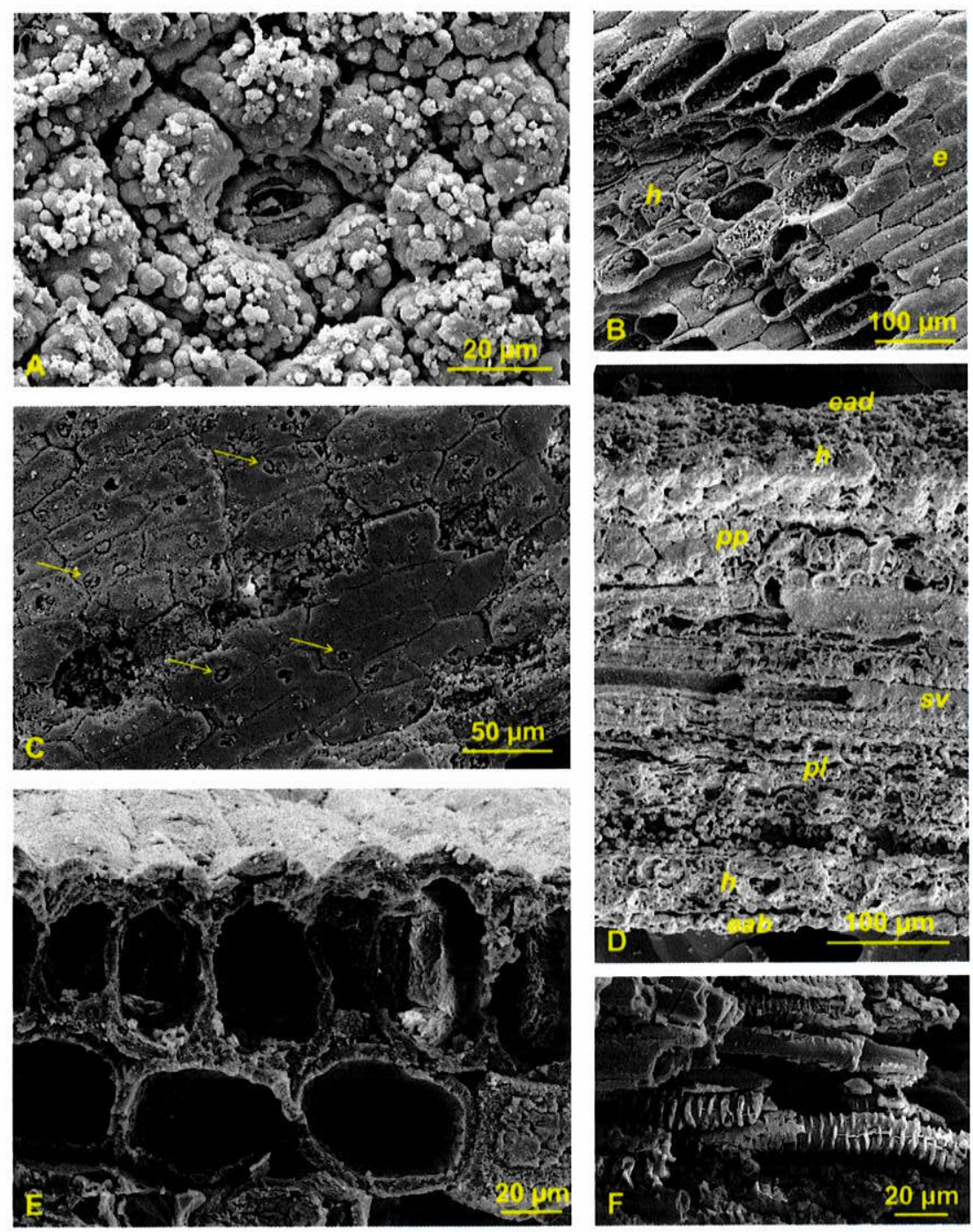

Figura 4.3. Detalhes epidérmicos e anatômicos preservados tridimensionalmente em fósseis da Formação Crato que sofreram processo de cimentação autigênica. A, C, D e F (Fotografías extraídas de Sucerquia, 2006); B e E (Fotografías extraídas de Fanton, 2007).

A. Aparelho estomático mostrando 5 células subsidiárias e duas células guardiãs reniformes. B. Células epidérmicas ordinárias (e) e células da hipoderme (h). C. Células epidérmicas ordinárias mostrando pontos de inserção de pêlos ou papilas (setas). D. Corte longitudinal de folha mostrando a epiderme abaxial (eab), epiderma adaxial (ead), hipoderme (h), parênquima lacunoso (pl), parênquima paliçádico (pp) e o sistema vascular (sv). E. Traqueídes em seção transversal. F. Traqueídes com espessamentos helicoidais.

Fósseis piritizados do Eocene London Clay (Grimes et al. 2002) e piritizações obtidas experimentalmente em material recente (Grimes et al. 2001) apresentam algumas estruturas semelhantes às dos fósseis da Formação Crato (Figura 4.4). 

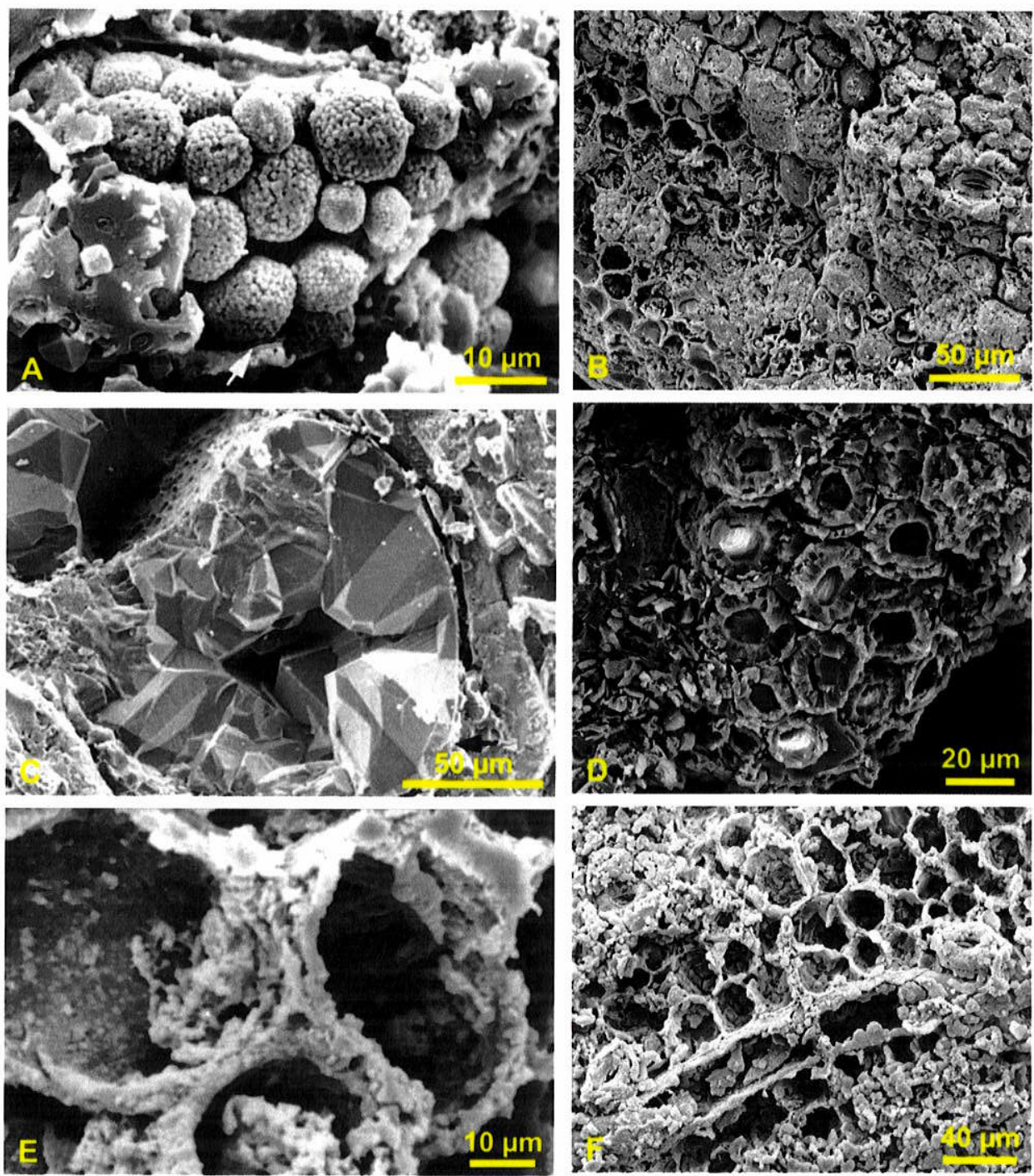

Figura 4.4. Comparações entre fósseis eocenos piritizados, material recente piritizado experimentalmente e as estruturas encontradas nos fósseis da Formação Crato. A. Fóssil piritizado do Eocene London Clay mostrando framboides de pirita preenchendo as células

(Fotografía extraída de Grimes et al. 2002). B. Estrutura semelhante em fóssil da Formação Crato (Fotografia extraída de Sucerquia, 2006). C. Fóssil piritizado do Eocene London Clay mostrando crescimento radial de pirita em espaços vazios (Fotografía extraída de Grimes et al. 2002). D. Estrutura semelhante em fóssil da Formação Crato (Fotografia extraída de Fanton, 2007). E. Piritização experimental em material recente mostrando a criação de moldes em paredes celulares (Fotografia extraída de Grimes et al.

2001). F. Estrutura semelhante em fóssil da Formação Crato (Fotografia extraída de Sucerquia, 2006).

Numa análise de espectrometria dispersiva de raio X em fósseis da Formação Crato, não foi confirmada a presença de pirita pela ausência de enxofre nos espectros

(Figuras 4.5 A e B). Entretanto, essas análises não são excludentes da possibilidade de 
um processo preliminar de piritização seguido de oxidação ter ocorrido nos fósseis da Formação Crato.

Na Figura 4.5B, os espectros obtidos do material constituinte do molde da parede e aquele do preenchimento do lúmen celular são muito semelhantes. Considerando que a formação das paredes é anterior ao preenchimento da célula, aparentemente, as características ambientais não mudaram durante a atuação dos dois processos.
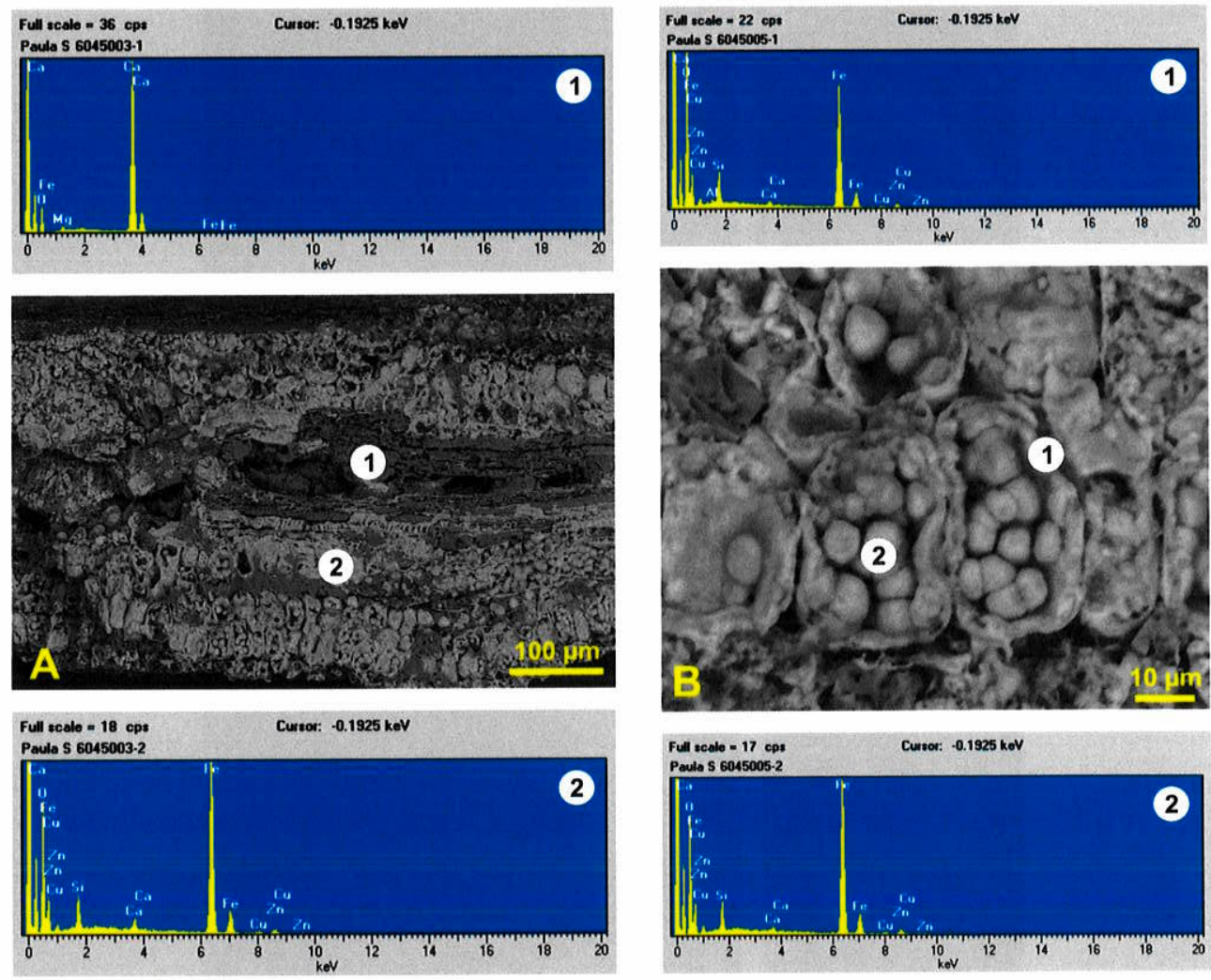

Figura 4.5. A. Análise de espectrometria dispersiva de raio $\mathrm{X}$ em corte longitudinal de folha (Amostra GP/3E 7480 b). 1. Espectro obtido no sistema vascular mostrando predominância de Cálcio, provávelmente o componente mineral seja calcita. 2. Espectro obtido em células parenquimâticas mostrando já a presença de Ferro. B. Análise de espectrometria dispersiva de raio $\mathrm{X}$ células de hipoderme de folha. 1 . Espectro obtido no material constituinte do molde da parede da célula. 2. Espectro obtido em cristais ao interior da célula.

A precipitação de minerais de ferro sobre superfícies vegetais, em estudos experimentais encontrados na literatura, tem sido possível somente na presença de bactérias ou biofilmes (Dunn et al. 1997; Brock, et al. 2006; Grimes et al. 2001). Este 
processo pode ocorrer em poucas semanas ou meses, sob ambientes anóxicos e com intensa atividade microbiana. Algumas estruturas presentes nos macrofitofósseis da Formação Crato, observáveis sob MEV, se assemelham às evidências da ação de microorganismos (tais como bactérias e fungos) durante os processos de fossilização (Figura 4.6).
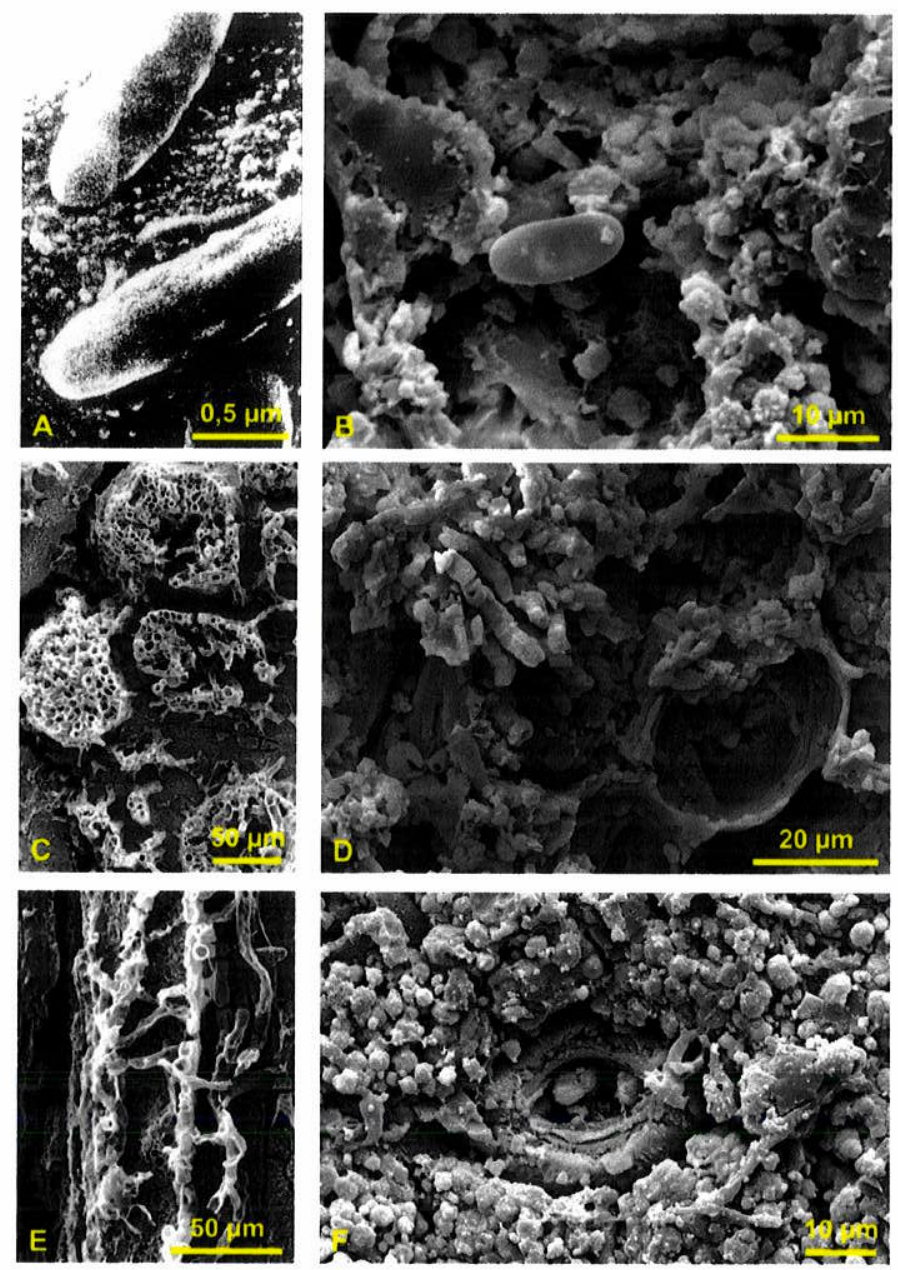

Figura 4.6. A. Evidência de atividade microbiana em folha recente deixada em méio aquoso e que foi incrustada com óxidos de ferro (Fotografia extraída de Dunn et al. 1997). B. Estrutura semelhante a bactéria em fóssil da Formação Crato. C e E. Fósseis piritizados do Eocene London Clay com hifas de fungo em traqueídes (Fotografía extraída de Grimes et al. 2002). D. Estruturas semelhantes a hifas de fungo em células epidérmicas de folha fóssil da Formação Crato. F. Estruturas semelhantes a hifas de fungo em aparelho estomático de fóssil da Formação Crato. 


\subsection{Fitogeografia}

Das famílias de coníferas que existiram no Gondwana Ocidental, durante o Eocretáceo: Araucariaceae, Cheirolepidiaceae, Podocarpaceae e Cupressaceae (Archangelsky \& del Fueyo, 2010), somente foram encontradas, até o momento as duas primeiras na região setentrional da América do Sul.

A Família Araucariaceae, que era amplamente distribuída durante o Mesozoico em ambos os hemisférios (Gee \& Tidwell, 2010), tem sua distribuição atual considerada como um relicto do Gondwana (Kunzmann, 2007), ocorrente somente no hemisfério sul. A Família Cheirolepidiaceae possuía distribuição global durante o Mesozoico, e foi extinta no final do Cretáceo (Watson, 1988).

A presença de elementos da seção Eutacta do gênero Araucaria, é interessante do ponto de vista fitogeográfico já que atualmente não existem representantes desta seção e sim da seção Araucaria na flora sul-americana. Esta poderia estar também representada na Formação Crato por megaestróbilos e complexos bráctea-escama descritos aqui como Araucaria sp. 1, mas que requerem uma analise mais detalhada.

Os complexos bráctea-escama da flora da Formação Paja, atribuídos ao gênero Carpolithes, não estariam relacionados com a seção Eutacta, já que, embora precisem ser estudados em detalhe, apresentam maior semelhança com complexos brácteaescama da seção Bunya.

Tanto a seção Bunya como a seção Eutacta são consideradas as mais antigas dentro do gênero Araucaria, com registro a partir do Jurássico (Axsmith et al., 2008) e distribuição global durante esse período e o Eocretáceo, mas atualmente são restritas a Oceania e sudeste asiático (Kershaw \& Wagstaff, 2001). Segundo os mesmos autores, a seção Araucaria tem registro raro, somente a partir do Cretáceo Inferior, e restrito ao Gondwana Austral.

A diversidade aparente do gênero Araucaria, durante o Eocretáceo, na América do Sul, representada pelas seções Araucaria, Bunya e Eutacta (Archangelsky \& Del Fueyo, 2010), sofreu declínio desde o final do Cretáceo com a extinção das seções Eutacta e Bunya, deixando como únicas representantes duas espécies da seção Araucaria restritas ao Brasil meridional, Chile e Argentina, adaptadas a ambientes com stress hídrico. 
0 registro do gênero Pseudofrenelopsis, nas duas paleofloras estudadas nesta tese, constitui uma extensão da distribuição latitudinal deste gênero e a espécie $P$. capillata, considerada como endêmica da Formação Crato, é a sua ocorrência mais sulina.

A morfologia dos espécimes de Pseudofrenelopsis, ocorrentes na flora da Formação Paja, é diferente daquela encontrada em P. capillata da Formação Crato. Por outro lado, os espécimes colombianos apresentam maior semelhança morfológica com os da espécie P. varians do Texas (EUA) figurados em Watson (1988, Fig. 9.19 A-D), podendo se tratar da mesma espécie. Isto poderia ser explicado pela proximidade paleogeográfica entre estas regiões, como pode ser visto na Figura 2 do Anexo 3.

Não foram achadas, até o momento, grandes diferenças na composição das coníferas entre os espécimes das paleofloras estudadas, pois ambas possuem as famílias Araucariaceae e Cheirolepidiaceae, com alguns gêneros em comum e nenhuma evidência na composição florística que possa indicar uma subdivisão na região equatorial.

Outras famílias de coníferas ocorrentes no registro fóssil da América do Sul, como Podocarpaceae e Cupressaceae (Archangelsky \& Del Fueyo, 2010), não tiveram sua presença confirmada dentro das duas paleofloras estudadas, mas não se descarta sua ocorrência ali, já que existem muitas formas atribuíveis a coníferas que precisam ser melhor analisadas.

A presença de caracteres indicadores de xeromorfismo e halofitismo é comum em ambas as paleofloras, e os ambientes sedimentares interpretados para as duas formações que as contem, confirmam a possibilidade de terem estado sob estas condições paleoambientais.

Indicadores paleoclimáticos na morfologia e anatomia da paleoflora da Formação Crato, incluindo as coníferas, são discutidos em detalhe no Anexo 5.

O único caráter observado, até o momento, que poderia estabelecer uma grande diferença entre as duas paleofloras estudadas, seria a presença, na paleoflora da Formação Paja, de cones masculinos com brácteas largas e compridas que chegam a cobri-los totalmente. Poderia se pensar que esta característica seja adaptativa a 
clima seco, ou algum tipo de proteção contra predadores, ou ainda, algum estágio ontogenético no qual foram preservados.

Considerando que paleogeograficamente a Formação Paja se encontrava numa área litorânea e, portanto, mais exposta à umidade oceânica do que a Formação Crato, de posição mais intracontinental, foi descartada a possibilidade de que as características morfológicas anteriormente mencionadas sejam adaptativas ao clima mais seco.

Comparações anatômicas, entre as duas paleofloras estudadas, não foram possíveis de ser realizadas por causa da diferença de preservação destes detalhes em cada uma delas. 


\section{CAPÍTULO 5 - CONCLUSÕES}

Ao fazer a análise de restos fósseis de coníferas presentes nas paleofloras da Formação Crato e da Formação Paja, verificou-se que a presença do grupo foi muito importante na composição dessas floras eocretáceas. De um total de 179 espécimes analisados que se pensava pertencer ao grupo, na forma de fragmentos de ramos folhosos, cones femininos, cones masculinos e complexos bráctea-escama, foi reconhecida a afinidade com o grupo das coníferas em 130 espécimes, agrupados em pelo menos 15 espécies, discutidas nesta tese, sendo sete espécies da Formação Crato e oito, da Formação Paja. Foram incluídos entre os espécimes analisados, alguns dos holótipos de espécies anteriormente erigidas.

Há a possibilidade de que outras espécies, não discutidas aqui, possam ainda vir a ser avaliadas e incluídas dentro do grupo das coníferas, em trabalhos posteriores.

Quanto à análise taxonômica, constatou-se que duas famílias constituíram o grupo das coníferas nessas paleofloras: Família Araucariaceae e Família Cheirolepidiaceae e dentre elas duas novas espécies de coníferas ocorrentes na Formação Crato foram erigidas e sua formalização realizada, na forma de artigos submetidos a revistas de circulação internacional:

- Araucaria duarteae sp. nov., constituída por complexos bráctea-escama da Família Araucariaceae, com afinidade à Seção Eutacta do gênero Araucaria.

- Pseudofrenelopsis capillata sp. nov., constituída por ramos folhosos da Família Cheirolepidiaceae.

A presença destas duas espécies na Formação Crato tem grande significado fitogeográfico: a seção Eutacta do gênero Araucaria, é registrada pela primeira vez para o Eocretáceo do Brasil, enquanto que o gênero Pseudofrenelopsis teve a sua distribuição latitudinal estendida para o sul. 
A preservação dos fitofósseis foi determinante dos métodos utilizados para sua análise. Dos métodos testados, para a paleoflora da Formação Crato, a microscopia eletrônica de varredura é o que produziu os resultados mais satisfatórios, enquanto para a paleoflora da Formação Paja, quando preservada a sua anatomia, a tomografia computadorizada consistiu num método com enorme potencial ainda pouco explorado, por outro lado, espécimes preservados como moldes só requiseram uso de estereomicroscópio.

No que se refere aos modos de preservação, concluiu-se que os fitofósseis da Formação Crato se preservam, principalmente, na forma de óxidos de ferro, mas também ocorrem preservados em pirita, charcoal, como incarbonizações e impressões. A preservação em óxidos de ferro, especificamente limonita/goethita, é o resultado de um processo de cimentação autigênica durante o qual foram formados moldes internos e externos dos tecidos dos organismos, preservando em grande parte a tridimensionalidade dos espécimes, chegando a ter nível celular de detalhamento. Este tipo de preservação foi demonstrado ocorrer na presença obrigatória de bactérias ou biofilmes. É importante ressaltar que não houve substituição mas sim moldagem das estruturas.

Na Formação Paja, a preservação da anatomia ocorre em petrificações calcárias, sem nenhum resto de tecido vegetal sendo vista a morfologia mais grosseira em moldes internos e externos.

No que se refere à fitogeografia, não foram achadas, até o momento, com os espécimes analisados, grandes diferenças na composição das coníferas eocretáceas de ambas as paleofloras, que possam evidenciar uma subdivisão da região paleoequatorial. Uma diferenciação dessas paleofloras poderia ser estabelecida com base na associação de outros elementos destas paleofloras, como é o caso do grupo das Gnetales e das Pteridófitas. 
Também os caracteres morfológicos e anatômicos atuantes como indicadores paleoclimáticos, apesar de presentes nas duas paleofloras, e que poderiam ser usados para evidenciar alguma diferença paleoflorística, não permitem estabelecer diferenciação entre elas. Ramos de aparência suculenta, com folhas coriáceas e adpressas, aparecem nas duas paleofloras estudadas. Enquanto características anatômicas como: cutículas espessas, estômatos afundados e presença de papilas, são somente observáveis na paleoflora da Formação Crato, existindo portanto uma tendência interpretativa marcada pela qualidade na preservação. 
ANDERSON, J.M., ANDERSON, H.M. 1983: Palaeoflora of southern Africa. Molteno Formation (Triassic). Part 1. Introduction. Part 2. Dicroidium. Volume 1. A.A. Balkema, Rotterdam, 567 p.

ANDERSON, J.M., ANDERSON, H.M. 1985. Paleoflora of Southern Africa. Prodromus of South African Megafloras, Devonian to Lower Cretaceous. A.A. Balkema, Rotterdam, $423 \mathrm{p}$.

ARAI, M., COIMBRA, J.C., SILVA-TELLES, A.C., 2001. Síntese bioestratigrafica da Bacia do Araripe (Nordeste do Brasil). In: Simpósio sobre a Bacia do Araripe e Bacias Interiores do Nordeste, I, Crato, 1990. Comunicações do I e II Simpósio sobre a Bacia do Araripe e Bacias Interiores do Nordeste, Crato, p. 109-118.

ARAI, M., HASHIMOTO, A.T., UESUGUI, N. 1989. Significado cronoestratigráfico da associação micriflorística do Cretáceo Inferior de Brasil. Boletim de Geociências da PETROBRÁS 3: 87-103.

ARCHANGELSKY, A., ANDREIS, R.R., ARCHANGELSKY, S., ARTABE, A. 1995. Cuticular characters adapted to volcanic stress in a new Cretaceous cycad leaf from Patagonia, Argentina: Considerations on the stratigraphy and depositional history of the Baqueró Formation. Review of Palaeobotany and Palynology, 89: 213-233.

ARCHANGELSKY, S. 1963a. Notas sobre la flora fósil de Ticó, provincia de Santa Cruz. Introducción y nota I. Cladophlebis tripinnata n. sp. Ameghiniana 3: 57-62.

ARCHANGELSKY, S. 1963b. Notas sobre la flora fósil de Ticó, provincia de Santa Cruz. 2. Tres nuevas especies de Mesosingeria. Ameghiniana 3: 113-120.

ARCHANGELSKY, S. 1963c. A new Mesozoic flora from Ticó, Santa Cruz province, Argentina. British Museum (Natural History) Bulletin of Geology 8: 47-92.

ARCHANGELSKY, S. 1964a. Notas sobre la flora fósil de Ticó, provincia de Santa Cruz. 5. Sphenopteris cf. goepperti Dunker. 6. Cladophlebis sp. Ameghiniana 3: 280284.

ARCHANGELSKY, S. 1980. Palynology of the Lower Cretaceous in Argentina. Proceedings of the Fourth International Palynology Conference, Lucknow 2: 425428.

ARCHANGELSKY, S., 1964b. Cutinized fern-like fronds from Lower Cretaceous of Patagonia, Argentina. In: International Botanical Congress X. Edinburgh. 
ARCHANGELSKY, S., 1965a. Fossil Ginkgoales from the Ticó flora, Santa Cruz Province, Argentina. British Museum (Natural History) Bulletin of Geology 10, 119-137.

ARCHANGELSKY, S., 1965b. Dos nuevas localidades con plantas fósiles del Baqueroense (Cretácico Inferior) de la provincia de Santa Cruz. Revista del Museo de La Plata Paleontología, 4, 247- 257.

ARCHANGELSKY, S., 1966. New Gimnosperm from Ticó, Santa Cruz Province, Argentina. British Museum (Natural History) Bulletin of Geology 13, 259-295.

ARCHANGELSKY, S., 1967a. Estudio de la Formación Baqueró. Cretácico Inferior de Santa Cruz, Argentina. Revista del Museo de La Plata Paleontología, 5, 63-171.

ARCHANGELSKY, S., 1967b. Notas sobre la flora fósil de la zona de Ticó, provincia de Santa Cruz. 8. Seis especies del género Sphenopteris. Ameghiniana 5, 149-157.

ARCHANGELSKY, S., 1979. Paleoecología del Paleozoico Superior Argentino sobre la base de sus plantas fósiles. Ameghiniana 15, 73-84.

ARCHANGELSKY, S., BALDONI, A.M. 1972a. Notas sobre la Flora Fósil de Ticó. X. Dos nuevas especies de Pseudoctenis (Cycadales). Ameghiniana 9 (3): 241-257.

ARCHANGELSKY, S., BALDONI, A.M. 1972b. Revisión de las Bennettitales de la Formación Baqueró (Cretácico Inferior), Provincia de Santa Cruz. I. Hojas. Revista del Museo de La Plata Paleontología 7: 185-265.

ARCHANGELSKY, S., DEL FUEYO, 1989. Squamastrobus gen. n., a fertil podocarp from the early Cretaceous of Patagonia, Argentina. Review of Paleobotany and Palynology 59, 109-126.

ARCHANGELSKY, S., DEL FUEYO, 2010. Endemism of Early Cretaceous conifers in Western Gondwana. In: Gee C.T. (ed.), Plants in Mesozoic Time: Morphological Innovations, Phylogeny, Ecosystems, Indiana University Press, pp. 247-268 .

ARCHANGELSKY, S., TAYLOR, T.N., 1986. Ultrastructural studies of fossil plants cuticles II. Tarphyderma gen. n., a Cretaceous conifer from Argentina. American Journal of Botany 73, 1577-1587.

ARCHANGELSKY, S., VILLAR DE SEOANE, L., 2004. Cycadean diversity in the Cretaceous of Patagonia, Argentina. Three new Androstrobus species from the Baqueró Group. Review of Palaeobotany and Palynology 131, 1-28.

ASPDEN, J.A., BONILLA, W., DUQUE, P., 1995. The El Oro metamorphic complex, Ecuador: geology and economic mineral deposits. Overseas Geology and Mineral Resources 67. British Geological Survey Publication, Nottingham, 63 p.

AXELROD, D.I. 1952. A Theory of Angiosperm Evolution. Evolution 6 (1): 29-60. 
AXELROD, D.I. 1959. Poleward Migration of Early Angiosperm Flora. Science 130 (3369): 203-207.

AXSMITH, B.J., ESCAPA, I.H., HUBER, P. 2008. An araucarian conifer bract-scale complex from the Lower Jurassic of Massachusetts: implications for estimating phylogenetic and stratigraphic congruence in the Araucariaceae. Palaeontologia Electrónica 11: 11.3.13A.

BALDONI, A., ARCHANGELSKY, S., 1983. Palinología de la Formación Springhill (Cretácico Inferior), subsuelo de Argentina y Chile Austral. Revista Española de Micropaleontología 15: 47-101.

BALDONI, A.M., 1974. Revisión de las Bennettitales de la Formación Baqueró (Cretácico Inferior), prov. de Santa Cruz. II Brácteas. Ameghiniana 11, 328-356.

BALDONI, A.M., 1979. Nuevos elementos paleoflorísticos de la tatoflora de la Fm. Spring Hill, límite Jurásico-Cretácico, subsuelo de Argentina, Australia y Sudáfrica. Ameghiniana 16, 103-119.

BALDONI, A.M., 1980. Análisis de algunas tatofloras Jurásicas e Eocretácicas de Argentina y Chile. In: II congreso Argentino de Paleontología y Estratigrafía y I Congreso Latinoamericano de Paleontología. Buenos Aires 1978. Actas 5, p 4165.

BALDONI, A.M., RAMOS, 1981. Nuevas localidades con plantas fósiles Cretácicas en la Cordillera Patagónica (provincia de Santa Cruz, República Argentina. In: VIII Congreso Geológico Argentino, San Luis, Actas IV... 752-759.

BALDONI, A.M., TAYLOR, 1983. Plant remains from a New Cretaceous site in Santa Cruz, Argentina. Review in Paleobotany and Palynology 39, 1301-1311.

BARNARD, P.W. 1973. Mesozoic Floras. In: N.F. Hughes ed.. Organisms and Continents thorough Time. Special Papers in Paleontology 12: 175-187.

BARREDA, V., ARCHANGELSKY, S., 2006. The southernmost record of tropical pollen grains in the mid-Cretaceous of Patagonia, Argentina. Cretaceous Research 27: 778-787

BARRON, E.J. 1983. A warm equable Cretaceous: the nature of the problem. EarthScience Reviews 19: 305-338.

BARRON, E.J. Peterson, W., Thompson, S., Pollard, D. 1993. Past climate and the role of ocean heat transport: Model simulations for the Cretaceous. Paleoceanography 8: 785-798. 
BATTEN, D.J. 1984. Palynology, climate and the development of Late Cretaceous floral provinces in the Northern Hemisphere: a review. In: P. Brenchley (Ed.) Fossils and climate. John Wiley and Sons, New York, pp. 127-164.

BERNARDES-DE-OLIVEIRA, M.E.C., MOHR, B., DINO, R., GUERRA-SOMMER, M., GARCIA, M.J., SUCERQUIA, P.R. 2007. As Floras Mesofíticas Brasileiras no Cnárioi Paleoflorístico Mundial. In: I. S. Carvalho; R. C. Cassab; C. Schwanke; M.A. Carvalho; A.C.S. Fernandes; M.A.C. Rodrigues; M.S.S. de Carvalho, M. Arai; M.E. Q. Oliveira (Org.) Paleontologia: Cenários da Vida Vol 1. 1 ed. Interciência, Rio de Janeiro, pp. 203-242.

BERNER, R.A. \& KOTHAVALA, Z. 2001. GEOCARB III: a revised model of atmospheric $\mathrm{CO}_{2}$ over Phanerozoic time. American Journal of Science 301: 182-204.

BERRY, E.W. 1922. Contribution to the Paleobotany of Perú, Bolivia and Chile. The Johns Hopkins University Studies in Geology 4: 47-65.

BERRY, E.W. 1939. Contribution to the paleobotany of Middle and South America. The fossil plants from Huallanca, Perú. The Johns Hopkins University Studies in Geology 13: 74-93.

BICE, K.L. \& NORRIS, R.D. 2002. Possible atmospheric $\mathrm{CO}_{2}$ extreme of the Middle Cretaceous (late Albian-Turonian). Paleoceanography 17: 22/1-22/17.

BLAKEY, R. 2006. Global paleogeographic views of Earth History - late Precambrian ro Recent: paleogeographic map in rectangular format. Última atualização em 13 de outubro de 2006. http://jan.ucc.nau.edu/ rcb7/globaltext2.html. Acesso em 25 de outubro de 2006.

BOSCH, D., GABRIELE, P., LAPIERRE, H., MALFERE, J-L., JAILLARD, E., 2002. Geodynamic significance of the Raspas Metamorphic Complex (SW Ecuador): geochemical and isotopic constraints. Tectonophysics 345, 83-102.

BOURGOIS, J., TOUSSAINT, J.F., GONZALEZ, H., AZEMA, J., CALLE, B., DESMET, A., MURCIA, L.A., ACEVEDO, A.P., PARRA, E., TOURNON, J., 1987. Geological history of the Cretaceous ophiolitic complexes of northwestern South America (Colombian Andes). Tectonophysics 143, 307-327.

BOWE, L.M.; LE COAT,G.; DEPAMPHILIS, C.W., 2000, Phylogeny of seed plants based on all three genomic compartments: Extant gymnosperms are monophyletic and Gnetales' closest relatives are conifers. PNAS, 97 (8): 4092-4097.

BRENNER, G.J. 1976. Middle Cretaceous floral provinces and early migrations of Angiosperms. In: C. B. Beck (ed.), Origin and early evolution of angiosperms. Columbia University Press, New York, USA, pp. 23-47. 
BRENNER, G.J. 1996. Evidence for earlier stage of angiosperm pollen evolution: a paleoequatorial section from Israel. In: Taylor, D.W.; L.J. Hickey (eds.) Flowering plants: origin, evolution and phylogeny, Chapman \& Hall, New York, pp. 91-115.

BROCK, F., PARKES, R.J., BRIGGS, D.E.G. 2006. Experimental pyrite formation associated with decay of plant material. Palaios 21: 499-506.

CÉSARI S.N., LIMARINO, C.O., LLORENS, M., PASSALIA, M.G., PEREZ LOINAZE, V., VERA E.I. 2011. High-precision late Aptian $U / P b$ age for the Punta del Barco Formation (Baqueró Group), Santa Cruz Province, Argentina. Journal of South American Earth Sciences 31(4): 426-431.

CHAW, S.M., PARKINSON, C.L., CHENG, Y., VINCENT, T.M., PALMER, J.D., 2000. Seed plant phylogeny inferred from three plant genomes: monophyly of extant gymnosperms and origin of gnetales from conifers. Proceedings of the National Academy of Sciences 97, 4086-4091.

CHONG, G. 1976. Las relaciones de los sistemas Jurásico y Cretácico en la zona preandina del Norte de Chile. In: Primer Congreso Geológico Chileno, Santiago, Actas del Primer Congreso Geológico Chileno, pp. 23-36.

COHEN.K.M.; FINNEY, S.; GIBBARD, P.L. 2013. International Commission on stratigraphy, January 2013. http://www.stratigraphy.org/ICSchart/ChronostratChart2013-01.pdf

COIFFARD, C.; MOHR, B.A.R.; BERNARDES-DE-OLIVEIRA, M.E.C., 2013. aguariba wiersemana gen. nov. et sp. nov., an Early Cretaceous member of crown group Nymphaeales (Nymphaeaceae) from northern Gondwana. Taxon. 62 (1):141151 .

COLlETTA, B., HEBRARD, F., LETOUZEY, J., WERNER, P., RUDKIEWICZ, J.L., 1990. Tectonic Style and crustal structure of the Eastern Cordillera (Colombia) from a balanced cross section. In: Letouzey, J. (Ed.), Petroleum and Tectonics in Mobile Belts. Edition Technic, Paris, 81-100.

COOPER, M.A., ADDISON, F.T., ALVAREZ, R., CORAL, M., GRAHAM, R.H., HAYWARD, A.B., HOWE, S., MARTINEZ, J., NAAR, J., PEÑAS, R., PULHAM, A.J., TABORDA, A., 1995. Basin development and tectonic history of the Llanos Basin, Eastern Cordillera, and Middle Magdalena Valley, Colombia. American Association of Petroleum Geologists Bulletin 79, 1421-1443.

CORTIÑAS, J., ARBE, H.A., 1981. Un nuevo afloramiento fosilífero de la Formacion Springhill en el noroeste de la provincia de Santa Cruz. Revista Asociación Geólogica Argentina 36, 212-214. 
CRABTREE, T.R. 1987. Angiosperms of the northern Rocky Mountains: Albian to Campanian (Cretaceous) megafossil floras. Annals of the Missouri Botanical Garden 74: 707-747.

CRANE, P.R. 1985. Phylogenetic analysis of seed plants and the origin of angiosperms. Annals of the Missouri Botanical Garden, 72, 716-793.

CRANE, P.R. 1987. Vegetational consequences of angiosperm diversification. In: E.M. Friss, W.G. Chaloner and P.R. Crane, eds., The Origins of Angiosperms and their Biological Consequences. New York: Cambridge University Press, pp. 107-144.

CRANE, P.R., FRIIS, E.M., PEDERSEN, K.R. 1995. The origin and early diversification of angiosperms. Nature 374: 27-33.

CRANE, P.R., LIDGARD, S. 1989. Angiosperm diversification and paleolatitudinal gradients in Cretaceous floristic diversity. Science 246: 675-678.

CREPET, W.L., NIXON, K.C., GANDOLFO, M.A. 2004. Fossil evidence and phylogeny: the age of major angiosperm clades based on mesofossil and macrofossil evidence from Cretaceous deposits. American Journal of Botany 91: 1666- 1682.

CÚNEO, R., GANDOLFO, M.A., 2005. Angiosperma leaves from the Kachaike Formation, Lower Cretaceous of Patagonia, Argentina. Review of Palaeobotany and Palynology, 136, 29-47.

DAVIES, T.J., BARRACLOUGH, T.G., CHASE, M.W., SOLTIS, P.S., SOLTIS D.E., SAVOLAINEN, V. 2004. Darwin's abominable mystery: Insights from a supertree of the angiosperms. Proceedings of the National Academy of Sciences of the United States of America 101 (7): 1904-1909.

DEL FUEYO, G.M., ARCHANGELSKY, A. 2002. Araucaria grandifolia Feruglio from the Lower Cretaceous of Patagonia, Argentina. Cretaceous Research 23: 265-277.

DEL FUEYO, G.M., ARCHANGELSKY, S., TAYLOR, T.N., 1990. Una nueva Podocarpácea fértil (Coniferal) del Cretácico Inferior de la Patagonia, Argentina. Ameghiniana 27, 63-73.

DEL FUEYO, G.M., ARCHANGELSKY, S., TAYLOR, T.N., 2009. Morenostrobus, a new substitute name for Morenoa Del Fueyo et al. 1990, non La Llave 1824. Ameghiniana 46, 215.

DEL FUEYO, M.G., L. VILLAR DE SEOANE, A. ARCHANGELSKY, V. GULER, M. LLORENS, S. ARCHANGELSKY, J.C. GAMERRO, E.A. MUSACCHIO, M. PASSALIA \& V BARREDA. 2007. Biodiversidad de las Paleofloras de Patagonia austral durante el Cretácico Inferior. Asoc. Paleontol. Arg. Publ. Esp. 11 Ameghiniana 50 aniversario: 101-122.DEL FUEYO, G.M., et al 2008 
DENGO, C.A., COVEY., M.C., 1993. Structure of the Eastern Cordillera of Colombia: implications for trap styles and regional tectonics. American Association of Petroleum Geologists Bulletin 77, 1315-1337.

DETTMANN M.E. 1986. Early Cretaceous palynoflora of subsurface strata correlative with the Koonwarra Fossil Bed, Victoria. In: P. A. Jell and J. Roberts, eds. Plants and invertebrates from the Lower Cretaceous Koonwarra fossil bed, South Gippsland, Victoria. Memoirs of the Association of Australasian Palaeontologists 3, pp. 79-110.

DEVORE, M.L., KENRICK, P., PIGG, K.B., KETCHAM, R.A., 2006. Utility of high-resolution X-ray computed tomography (HRXCT) for paleobotanical studies: an example using London Clay fruits and seeds. American Journal of Botany 93: 1848-1851.

DILCHER D.L., BERNARDES-DE-OLIVEIRA M.E., PONS D., LOTT T.A. 2005. Welwitschiaceae from the Lower Cretaceous of Northeastern Brazil. American Journal of Botany 92: 1294-1310.

DILCHER, D.L., SUN, G., JI, Q., LI, H. 2007. An early infructescence Hyrcantha decussata (comb. nov.) from the Yixian Formation in northeastern China. Proceedings of the National Academy of Sciences USA 104 (22): 9370-9374.

DOYLE, J., BIENS, P., DOEREKAMP, A., JARDINE, S. 1977. Angiosperm pollen from the pre-Albian Lower Cretaceous of equatorial Africa. Bulletim Centres de Recherches Exploration-Production Elf-Aquitaine 1 (2): 451-473.

DOYLE, J.A., DONOGHUE, M.J., 1992. Fossils and seed plant phylogeny reanalyzed. Brittonia 44, 89-106.

DOYLE, J.A., HICKEY, L.J. 1976. Pollen and leaves from the mid-Cretaceous Potomac Group and their bearing on early angiosperms evolution. In: Beck, C.B., (ed), Origin and early evolution of angiosperms. Columbia University Press, New York, pp. 139-206.

DOYLE, J.A., JARDINE, S., DOERENKAMP, A. 1982. Afropollis, a new genus of early angiosperm pollen, with notes on the Cretaceous palynostratigraphy and paleoenvironments of northern Gondwana. Bulletin des Centre de Recherches Exploration-Production, Elf-Aquitaine 6: 39-117.

DRINNAN, A.N., CRANE, P.R. 1990. Cretaceous paleobotany and its bearing on the biogeography of austral angiosperms. In: Taylor T.N. and E.L. Taylor (eds.), Antarctic Paleobiology: its role in the reconstruction of Gondwana. SpringerVerlag, New York, pp. 192-219.

DUARTE, L., 1985. Vegetais fósseis da Chapada do Araripe. In: D.A. Campos et al. (eds.), Coletânea de Trabalhos Paleontológicos, Série Geologia, Brasilia, p. 557563. 
DUARTE, L., 1989. Remains of the Lower Cretaceous plants of North-East of Brazil. In: XI Congresso Brasileiro de Paleontologia, Curitiba, 1989. Anais do XI Congresso Brasileiro de Paleontologia, Curitiba, 1989, I, 223-225.

DUARTE, L., 1993. Restos de Araucariáceas da Formação Santana - Membro Crato (Aptiano), NE do Brasil. Anais da Academia Brasileira de Ciências 65, 357-362.

DUARTE, L., JAPIASSÚ, A.M.S. 1971. Vegetais Meso e Cenozóicos do Brasil. Anais da Academia Brasileira de Ciências 43 (Suplemento): 433-443.

DUNN K.A., MCLEAN, R.J.C., UPCHURCH, JR.G.R., FOLK, R.L. 1997. Enhancement of leaf fossilization potential by bacterial biofilms. Geology 25 (12): 1119-1122.

DUTRA, T.L., STRANZ, A., 2002. Clarificação e diafanização de folhas. In: T.L. Dutra (ed.), Técnicas e procedimentos de trabalho com fósseis e formas modernas comparativas, p. 27-29.

ETAYO-SERNA, F. 1979. Zonation of the Cretaceous of central Colombia by ammonites. Publicaciones Geológicas Especiales del Ingeominas 2: 1-186.

ETAYO-SERNA, F. 1985. Documentación paleontológica del infracretácico de San Félix y Valle Alto, Cordillera Central. In: F. Etayo Serna \& F. Laverde (Editors), Proyecto Cretácico. INGEOMINAS. Publicaciones Geológicas Especiales del INGEOMINAS, (16): XXV, 1-7. Bogotá.

ETAYO-SERNA, F., BARRERO, D., LOZANO, H., ESPINOSA, A., GONZÁLEZ, H., ORREGO, A., ZAMBRANO, F., DUQUE, H., VARGAS, R., NÚÑEZ, A., ÁLVAREZ, J., ROPAÍN, C., BALLESTEROS, I., CARDOZO, E., FORERO, H., GALVIS, N., RAMÍREZ, C., SARMIENTO, L., 1983. Mapa de terrenos geológicos de Colombia. Ingeominas, Publicación Especial Geología 14, Bogotá, 235p.

FAIRON-DEMARET, M., HILTON, J., BERRY, C.M. 1999. Surface preparation of macrofossils (dégagement). In: Jones, T.P., Rowe, N.P., (eds.), Fossil Plants and Spores: Modern Techniques. Geological Society, London, pp. 33-35.

FANTON, J.C.M. 2007. Novas gimnospermas e possível angiosperma da Paleoflora Crato, Eocretáceo da Bacia do Araripe, Nordeste do Brasil. Dissertação de Mestrado, Universidade Estadual de Campinas, $194 \mathrm{p}$.

FANTON, J.C.M., BRANCO, F. R., DILCHER, D., BERNARDES-DE-OLIVEIRA, M.E.C., 2006. Iara, A New Genus of Aquatic Angiosperm from the Crato Paleoflora (Lower Cretaceous, Santana Formation, Araripe Basin, Northeastern Brazil). In: 7 Simpósio do Cretáceo do Brasil / 1 Simpósio do Terciário do Brasil, 2006, Serra Negra. Boletim.... Rio Claro: UNESP, 2006. p. 50.

FRAKES, L.A. 1979. Climates Throughout Geologic Time. Amsterdam, Elsevier, 310 p. 
FRAKES, L.A., FRANCIS, J.E., \& SYKTUS, J.I. 1992. Climate Modes of the Phanerozoic. Cambridge, Cambridge University Press, $274 \mathrm{p}$.

FRIIS, E., W. CHALONER, AND C. P. 1987. Introduction to angiosperms. In: E.M. Friis, W.G. Chaloner, P.R. Crane. (eds.) The origin of angiosperms and their biological consequences, Cambridge University Press, pp. 1-15.

FRIIS, E.M., CR $\Lambda$ NE, P.R., PEDERSEN, K.R., BENGSTON, S., DONOGHUE, P.C.J., GRIMM, G.W., STAMP $\triangle N O N I, M$. 2007. Phase-contrast X-ray microtomography links Cretaceous sceds with Gnetales and Bennettitales. Nature 450: 549-553.

FRIIS, E.M., PEDERSEN, K.R., CRANE, P.R. 1994. Angiosperm floral structures from the Early Cretaccous of Portugal. Plant Systematics and Evolution 8 (Supplement): 31-49.

FRIIS, E.M., PEDERSEN, K.R., CRANE, P.R. 1999. Early angiosperm diversification: the diversity of pollen associated with angiosperm reproductive structures in Early Cretaccous floras from Portugal. Annals of the Missouri Botanical Garden 86: 259-296.

FRIIS, E.M., PEDERSEN, K.R., CRANE, P.R. 2001. Fossil evidence of water lilies (Nymphacales) in the Early Cretaceous. Nature 410 (6826): 357-360.

GALTIER, J. \& PHIIIIIPS, T.L. 1999. The acetate peel technique. In: Jones, T.P., Rowe, N.P., (eds.), liossil Plants and Spores: Modern Techniques. Geological Society, London, pp. 67-70.

GEE, C.T., TIDWEIL, W.D. 2010. A mosaic of characters in a new whole-plant Araucaria, $\Lambda$. delevoryasii Gee sp. nov., from the Late Jurassic Morrison Formation of Wyoming, U.S.A. In: Gee C.T. (ed.), Plants in Mesozoic Time: Morphological Innovations, Phylogeny, Ecosystems, Indiana University Press, pp. 67-94.

GRIMES, S.T., BROCK, r., RICKARD D., DAVIES, K.L., EDWARDS, D., BRIGGS, D.G., PARKI:S, R.J. 2001. Understanding fossilization: Experimental pyritization of plants. (ieclogy 29 (2): 123-126.

GRIMES, S.T., DAVIISS, K.L., BUTLER, I.B., BROCK, F., EDWARDS, D., RICKARD, D., BRIGGS, D.G., PARKES, R.J. 2002. Fossil plants from the Eocene London Clay: the use of pyrite textures to determine the mechanism of pyritization. Journal of the (icological Society 159: 493-501.

GULLER, M.V., ARCHANGELSKY, S. 2006. Albian dinoflagellate cysts from the Kachaike Formation, Austral Basin, Southwest Argentina. Revista del Museo Argentino de Ciencias Natura- les, n.s., 8: 179-184. 
HALLE, T.G., 1913. Some Mesozoic plant bearing deposits in Patagonia and Tierra del Fuego and their floras. Kunglinga Svenska Vetensakapakademien Handlingar. 51 (3): 1-58.

HASS H. \& ROWE N.P. 1999. Thin sections and wafering. In: Joncs, T.P., Rowe, N.P., (eds.), Fossil Plants and Spores: Modern Techniques. Geological Society, London, pp. 76-81

HAY, W.W., FLÖGEL, S. 2012. New thoughts about the Cretaceous climate and oceans Earth-Science Reviews, 115 (4): 262-272.

HEIMHOFER, U., MARTILL, D.M. 2007. The sedimentology and depositional environment of the Crato Formation. In: Martill, D. M., Bechly, G. \& Loveridge, R. F. (eds). The Crato Fossil Beds of Brazil. Window into an Ancient World. Cambridge University Press, Cambridge, pp. 44-62.

HERBST, R., 1962. Sobre as especies de Gleichenites de los sedimentos baqueroenses de Santa Cruz, Patagonia. Ameghiniana 2 (8): 141-151.

HERMAN, A.B. \& SPICER, R.A. 1996. Palaeobotanical evidence for a warm Cretaceous Arctic Ocean. Nature 380: 330-333.

HERNANDEZ-CASTILLO, G.R., STOCKEY, R.A., MAPES, G. \& ROTHWELL, G.W. 2009. A New Voltzialean Conifer Emporia royalii sp. nov. (Emporiaceae) from the Hamilton Quarry, Kansas. International Journal of Plant Sciences. 170 (9): 1201-1227.

HERNGREEN, G.F.W., CHLONOVA, A.F. 1981. Cretaceous microfloral provinces. Pollen et Spores 23 (3-4): 441-555.

HERNGREEN, G.F.W., KEDVES, M., ROVNINA, L.V., SMIRNOVA, S.B. 1996. Chapter 29C. Cretaceous palynofloral provinces: a review. In: Jansonius, J., Mcgregor, D.C. (eds.), Palynology: principles and applications, American Association of Stratigraphic Palynologists Foundation, 3: 1157-1188.

HICKEY, L.J., DOYLE, J.A. 1977. Early Cretaceous fossil evidence for angiosperm evolution. Botanical Review 43: 3-104.

HOEDEMAEKER, P.J. 2004. On the Barremian - lower Albian stratigraphy of Colombia. Scripta Geologica 128: 3-15.

HOLZ, M., SIMÕES, M.G. 2002. Elementos fundamentais de tafonomia. Ed. Universidade/UFRGS, Porto Alegre, 231 p.

HUERTAS, G. 1967. Sertum florulae fossilis Villae de Leivae. Caldasia 10 (46): 59-75.

HUERTAS, G. 1970. Sertum florulae fossilis Villae de Leivae. Caldasia 10 (50): 595602. 
HUERTAS, G. 1971. Theobroma verum sp. nov., Mutisia. 34: 1-10.

HUERTAS, G. 1976. Sertum florulae fossilis Villae de Leivae. Caldasia 11 (54): 17-23.

HUERTAS, G., 2003. Flora Fósil de Villa de Leyva y sus alrededores. Editorial Linotipia Bolívar, Colômbia, 152 p.

HUGHES, N.F. 1994. The Enigma of Angiosperm Origins. Cambridge University Press, Cambridge., 320 p.

HUGHES, N.F., MCDOUGALL, A. 1990. Barremian-Aptian Angiospermid Pollen Records from Southern England. Review of Palaeobotany and Palynology 65 (1-4): 145151.

INGEMMET. 1995. Boletin 55 Geología del Perú (Mapa Escala 1: 2000000), Serie A: Carta Geológica Nacional, 177 p.

JENKYNS, H.C. 2003. Evidence for rapid climate change in the Mesozoic-Palaeogene greenhouse world. Philosophical Transactions of the Royal Society of London 361: 1885-1916.

KELLER, G. 2008. Cretaceous climate, volcanism, impacts and biotic effects. Cretaceous Research 29 (5-6): 754-771.

KENNAN, L., PINDELL, J.L., 2009, Dextral shear, terrane accretion and basin formation in the Northern Andes: best explained by interaction with a Pacific-derived Caribbean Plate?. Geological Society Special Publications 328: 487-531.

KENRICK, P. 1999. Opaque petrifaction techniques. In: Jones, T.P., Rowe, N.P., (eds.), Fossil Plants and Spores: Modern Techniques. Geological Society, London, pp. 8791.

KENRICK, P., DAVIS, P.G. 2004. Fossil Plants. The Natural History Museum, London, $207 \mathrm{pp}$.

KERKHOFF, M.L.H., DUTRA, T.L., STRANZ, A., 2005. Ramos reprodutivos de gnetales na Formação Santana (Cretáceo Inferior), Ceará, Brasil. In: XIX Congresso Brasileiro de Paleontologia, Aracaju. Boletim de Resumos.

KERSHAW, P., WAGSTAFF, B., 2001. The southern conifer family Araucariaceae: history, status, and value for palaeoenvironmental reconstruction. Annual Review Ecology and Systematics 32: 397-414.

KIDDER, D.L., WORSLEY, T.R. 2010. Phanerozoic large igneous provinces (LIPs), HEATT (Haline Euxinic Acidic Thermal Transgression) episodes and mass extinctions. Palaeogeography, Palaeoclimatology, Palaeoecology 295: 162-191. 
KIMURA, K. 2000, Early Cretaceous climatic provinces in Japan and adjacent regions on the basis of fossil land plants. In: Okada, H. and Mateer, N.J. (eds.), Cretaceous Environments of Asia, Elsevier Science B.V., pp. 155-161.

KRASSILOV, V. 1972. Phytogeographical Classification of Mesozoic Floras and their bearing on Continental Drift. Nature 273: 49-50.

KRINGS, M., HASS, H., KERP, H., TAYLOR, T.N., AGERER, R., \& DOTZLER, N. 2009. Endophytic cyanobacteria in a 400-million-yr-old land plant: A scenario for the origin of symbiosis? Review of Palaeobotany and Palynology 153: 62-69

KUNZMANN, L., 2007. Araucariaceae (Pinopsida): aspects in palaeobiogeography and palaeobiodiversity in the Mesozoic. Zoologisher Anzeiger 246, 257-277.

KUNZMANN, L., MOHR, B., BERNARDES-DE-OLIVEIRA, M.E.C. 2004. Gymnosperms from the Lower Cretaceous Crato Formation (Brazil). I. Araucariaceae and Lindleycladus (incertae sedis). Mitteilung aus dem Museum für Naturkunde Berlin, Geowissenschaftliche Reihe 7: 155-174.

KUNZMANN, L., MOHR, B., BERNARDES-DE-OLIVEIRA, M.E.C. 2007. Novaolindia dubia gen. et sp. nov., an enigmatic seed plant from the Early Cretaceous of northern Gondwana. Review of Palaeobotany and Palynology 147: 94-105

KUNZMANN, L., MOHR, B., BERNARDES-DE-OLIVEIRA, M.E.C., 2011. A putative gnetalean gymnosperm Cariria orbiculiconiformis gen. nov. et spec. nov. from the Early Cretaceous of northern Gondwana. Rev. Palaeobot. Palynol., 156 (1-2) (2011): 75-95.

KUNZMANN, L., MOHR, B., BERNARDES-DE-OLIVEIRA, M.E.C., 2009. Cearania heterophylla gen. nov. et sp. nov., a fossil gymnosperm with affinities to the Gnetales from the Early Cretaceous of northern Gondwana. Rev. Palaeobot. Palynol., 158 (1-4) (2009): 193-212

KUNZMANN, L., MOHR, B., BERNARDES-DE-OLIVEIRA, M.E.C., WILDE, V. 2006. Gymnosperms from the Lower Cretaceous Crato Formation (Brazil). II. Cheirolepidiaceae. Fossil Record 9 (2): 213-225.

LABANDEIRA, C.C., DILCHER, D.L., DAVIS, D.R., WAGNER, D.L. 1994. Ninety-seven million years of angiosperm-insect association: paleobiological insights into the meaning of coevolution. Proceedings of the National Academy of Sciences USA 91: 12278-12282.

LAPASHA, C.A. MILLER, C.N. 1984. Flora of the Early Cretaceous Kootenai Formation in Montana: Paleoecology. Palaeontographica Abteilung B 194: 109-130. 
LARSON, R.L., ERBA, E. 1999. Onset of the mid-Cretaceous greenhouse in the Barremian-Aptian: igneous events and the biological, sedimentary, and geochemical responses. Paleoceanography, 14: 663-678.

LEMOIGNE, Y. 1984. Données nouvelles sur la paléoflore de Colombie. Geobios 17: 667-690.

LIDGARD, S., CRANE, P.R. 1988. Quantitative-Analyses of the Early Angiosperm Radiation. Nature 331 (6154): 344-346.

LIDGARD, S., CRANE, P.R. 1990. Angiosperm Diversification and Cretaceous Floristic Trends - a Comparison of Palynofloras and Leaf Macrofloras. Paleobiology 16 (1): 77-93.

LIMARINO, C.O., PASSALIA, M.G., LLORENS, M., VERA, E.I., PEREZ LOINAZE, V.S., CÉSARI, S.N. 2012. Depositional environments and vegetation of Aptian sequences affected by volcanism in Patagonia. Palaeogeography Palaeoclimatology Palaeoecology. 323-325: 22-41.

LITHERLAND, M., ASPDEN, J.A., EGUEEZ, A., 1993. The geotectonic evolution of Ecuador in the Phanerozoic. In: ISAG 93; International Symposium on Andean Geodynamics; Extended Abstracts, 215-218.

LONGOBUCO, M.I., AZCUY, C.L., AGUIRRE-URRETA, B., 1985. Plantas de la Formación Kachaike, Cretácico de la provincia de Santa Cruz. Ameghiniana 21, 305-315.

LUPIA, R., LIDGARD, S., CRANE, P.R. 1999. Comparing palynologycal abundance and diversity: implications for biotic replacement during the Cretaceous angiosperm radiation. Paleobiology 25 (3): 305-340.

MAISEY, J. G. 1991. Santana fossils: an illustrated atlas. T.F.H. Publications, Neptune, N.J., USA, $459 \mathrm{p}$.

MAPES, G. \& ROTHWELL, G.W. 1984. Permineralized ovulate cones of Lebachia from Late Palaeozoic limestones of Kansas. Palaeontology 27: 69-94.

MARTILL, D.M. 1993. Fossil of the Santana and Crato formations, Brazil. Paleontological Association, Field Guide to Fossils, n. 5, 159 p.

MENDES, J.C., PETRI, S. 1971. Geologia do Brasil. Rio de Janeiro, Instituto Nacional do Livro - Ministério da Educação e Cultura, 207 p.

MENÉNDEZ, C.A., 1965. Sueria rectinervis n. gen. et sp. de la flora fósil de Ticó, provincia de Santa Cruz. Ameghiniana 4, 139-140.

MENÉNDEZ, C.A., 1966. Fossil Bennettitales from the Tico Flora, Santa Cruz Province, Argentina. British Museum (Natural History) Bulletin of Geology 12, 3-42. 
MEYEN, S.V. 1987. Fundamentals of palaeobotany. Chapman and Hall, London. 432 p.

MILLER I.M., BRANDON, M.T., HICKEY, L.J. 2006. Using leaf margin analysis to estimate the Mid-Cretaceous (Albian) paleolatitude of the Baja BC block. Earth and Planetary Science Letters 245: 95-114.

MOHR, B., BERNARDES-DE-OLIVEIRA, M.E.C, BARALE, G., OUAJA, M. 2006. Palaeogeographic distribution and ecology of Klitzschophyllites, and Early Cretaceous angiosperm in Southern Laurasia and Northern Gondwana. Cretaceous Research 27: 464-472.

MOHR, B., BERNARDES-DE-OLIVEIRA, M.E.C. 2004. Endressinia brasiliana, a Magnolialean angiosperm from the Lower Cretaceous Crato Formation (Brazil). International Journal of Plant Sciences 165: 1121-1133.

MOHR, B., BERNARDES-DE-OLIVEIRA, M.E.C., TAYLOR, D.W. 2009. Pluricarpellatia, a nymphaealean angiosperm from the Lower Cretaceous of northern Gondwana (Crato Formation, Brazil). Taxon 57 (4): 1147-1158.

MOHR, B., BERNARDES-DE-OLIVEIRA, M.E.C., TAYLOR, D.W., 2008. Pluricarpellatia.a nymphaealean angiosperm from the Lower Cretaceous of northern Gondwana (Crato Formation, Brazil). Taxon 57(4): 1-12.

MOHR, B., EKLUND, H. 2003. Araripia florifera, a magnoliid angiosperm from the Lower Cretaceous Crato Formation (Brazil). Review of Palaeobotany and Palynology 126: 279-292.

MOHR, B.A.R., COIFFARD, C., BERNARDES-DE-OLIVEIRA, M.E.C. 2013. Schenkeriphyllum glanduliferum, a new magnolialean angiosperm from the Early Cretaceous of Northern Gondwana and its relationships to fossil and modern Magnoliales. Review of Palaeobotany and Palynology. 189: 57-72.

MOHR, B.A.R., SCHULTKA, S., SUESS, H., BERNARDES-DE-OLIVEIRA, M.E.C. 2012. A new drought resistant gymnosperm taxon Duartenia araripensis n. gen. et sp. (Cheirolepidiaceae?) from the Early Cretaceous of Northern Gondwana. Palaeontographica Abt. B, Paläophytol. 289: 1-25.

MOHR., B., RYDIN, C. 2002. Trifurcatia flabellata n. gen. n. sp., a putative monocotyledon angiosperm from the Lower Cretaceous Crato Formation (Brazil). Mitteilung aus dem Museum für Naturkunde Berlin, Geowissenschaftliche Reihe 5: 335-344.

MOJICA, J., DORADO, J., 1987. El Jurásico anterior a los movimientos intermálmicos en los Andes Colombianos. Bioestratigrafía de los Sistemas Regionales del Jurásico y Cretácico de America del Sur, Mendoza, p. 49-110. 
MORENO-SÁNCHEZ, M., PARDO-TRUJILLO, A. 2003. Stratigraphical and sedimentological constrains on western Colombia: implications on the evolution of the Caribbean Plate. In: C. Bartolini, R.T. Buffler y J.F. Blickwede (Editors), The Circum-Gulf of Mexico and the Caribbean: hydrocarbon habitats, basin formation, and plate tectonics. American Association of Petroleum Geologist, memoir 79, pp. 891-924.

NEUMANN, V.H. 1999. Estratigrafia, sedimentologia, geoquímica y diagénesis de los sistemas lacustres aptiense-albienses de la Cuenca de Araripe (Noreste de Brasil). 244 p. Tesis Doctoral, Universitat de Barcelona, DEP, DGPPG.

NEUMANN, V.H., CABRERA, L., 1999. Una nueva propuesta estratigráfica para la tectonosecuencia post-rifte de la cuenca de Araripe, noreste de Brasil. In: Simpósio Cretáceo Brasileiro, 5, Serra negra, 1999. Boletim de Resumos, UNESP, p. 279- 285.

NEUMANN, V.H., BORREGO, A.G., CABRERA, L., DINO, R., 2003. Organic matter composition and distribution through the Aptian-Albian lacustrine sequences of the Araripe Basin, northeastern Brazil. International Journal of Coal Geology, 54 21-40.

NIXON K.C., W.L. CREPET, D. STEVENSON, E.M. FRIIS. 1994. A reevaluation of seed plant phylogeny. Annals of the Missouri Botanical Garden 81, 484-533.

PARRISH, J.T. 1987. Global palaeogeography and palaeoclimate of the late Cretaceous and early Tertiary. In: Friis, E.M., Chaloner, W.G., Crane, P.R., (eds.), The Origins of Angiosperms and their Biological Consequences. New York: Cambridge University Press, pp. 51-73.

PASSALIA, M.G., 2007. Nuevos registros para la flora cretácica descripta por Halle (1913) en lago San Martín, Santa Cruz, Argentina. Ameghiniana 44, 565-595..

PATARROYO, P. 2000. Distribución de ammonitas del Barremiano de la Formación Paja en el sector de Villa de Leyva (Boyacá, Colombia). Bioestratigrafía. Geología Colombiana 25: 149-162.

PATARROYO, P., MORENO, M., 1997. Nuevas Consideraciones en torno al Cabeceo del Anticlinal de Arcabuco, en cercanias de Villa de Leyva - Boyacá. Geología Colombiana 22: 27-34.

PFEFFERKORN, H.W. 1977. Plant megafossils in Venezuela and their use in geology. In: V Congreso Geológico Venezolano, Memoria I, V Congreso Geológico Venezolano, pp. 407-414.

PONS, D. 1982a. Decouverte de Crétacé moyen sur le flanc est du Massif de Quetame, Colombie. Comptes Rendus de la Academie des Sciences, Serie 2 294: 533-536. 
PONS, D. 1982b. Etudes paléobotaniques et palynologiques de la Formation Girón (Jurassique moyen - Crétacé inférieur) dans la région de Lebrija, département de Santander, Colombie. Comptes rendus du 107. Congrès national des sociétés savantes, Brest, 1982, Sciences 1: 53-78.

PONS, D. 1988. Le Mesozoique de Colombie. Macroflores et microflores. Cahiers de Micropaléontologie. Editions du Centre National de la Recherche Scientifique, Paris. 168 p.

PRASAD, V., STRÖMBERG, C.A.E., ALIMOHAMMADIAN, H., SAHNI, A. 2005. Dinosaur Coprolites and the Early Evolution of Grasses and Grazers. Science 310 (5751) : 1177 - 1180 .

REMY, W. \& HASS, H. 1996. New information on gametophytes and sporophytes of Aglaophyton major and inferences about possible environmental adaptations. Review of Palaeobotany and Palynology 90: 175-193.

RESTREPO, J.J., TOUSSAINT, J.F., 1982. Metamorfismos superpuestos en la Cordillera Central de Colombia: V Congreso Latinoamericano de Geología, Argentina. Actas 3, 505-512.

RESTREPO, J.J., TOUSSAINT, J.F., 1988. Terranes and continental accretion in the Colombian Andes. Episodes 11, 189-193.

RETALLACK, G.J. AND DILCHER, D.L., 1981a. A coastal hypothesis for the dispersal and rise to dominance of flowering plants. In K.J. Niklas, Editor, Paleobotany, Paleoecology, and Evolution, v. 1. Praeger, New York, 22-77.

ROMERO, E.J., ARCHANGELSKY, S. 1986. Early Cretaceous Angiosperms leaves from Southern South America. Science 234: 1580-1582.

ROMERO, L., ALDANA, M., RANGEL, C. VILLAVICENCIO, E., RAMIREZ, J. 1995. Boletin de fauna y flora fosil del Peru. Bol. 17, Serie D: Estudios Regionales, 332 p.

ROTHMAN, D.H. 2002. Atmospheric carbon dioxide levels for the last 500 million years. Proceedings of the National Academy of Sciences 99 (7): 4167-4171.

ROTHWELL, G.W. 1982. New interpretations of the earliest conifers. Review of Palaeobotany and Palynology 37: 7-28.

ROYO Y GÓMEZ, J. 1960. Los vegetales de la Formación Barranquín, Cretácico Inferior del estado Sucre. In: III Congreso Geológico Venezolano, 1959, Caracas. Memoria del III Congreso Geológico Venezolano, Caracas, 2, pp. 496-500.

RYDIN, C., MOHR, B., FRIIS, E.M., 2003. Cratonia cotyledon gen. et sp. nov. : a unique Cretaceous seedling related to Welwitschia. Proceedings of the Royal Society Biology Letters (Supplement) 270, S29-S32. 
SCHALLER, H. 1969. Revisão estratigráfica da Bacia de Sergipe-Alagoas. Boletim técnico da PETROBRÁS 12: 21-86.

SCHNEIDER, H., SCHUETTPELTZ, E., PRYER, K., CRANFILL, R., MAGALLON, S., LUPIA R. 2004. Ferns diversified in the shadow of angiosperms. Nature 428: 553-557.

SCHOPF, J.M. 1975, Modes of fossil preservation. Review of Palaeobotany and Palynology 20: 27-53.

SELDEN P.A., NUDDS, J.R. 2005. Evolution of Fossil Ecosystems. Manson Publishing, Ltd., London, 192 p.

SELLWOOD, B.W., VALDES, P.J. 2006. Mesozoic climates: general circulation models and the rock record. Sedimentary Geology 190: 269-287.

SETOGUCHI H, OSAWA TA, PINTAUD JC, JAFFRE T, VEILLON JM. 1998. Phylogenetic relationships within Araucariaceae based on RBCL gene sequences. American Journal of Botany 85: 1507-1516.

SHOEMAKER, R.E. 1977. La geologia y paleontologia de los sedimentos cretácicos del Valle del Río Puyando, Prov. de la Loja y El Oro, Ecuador. Baltimore, Tawson State University. Presentado a: Subcomisión ecuatoriana, Quito, 39 p.

SHOEMAKER, R.E., 1977. La geologia y paleontologia de los sedimentos cretácicos del Valle del Río Puyando, Prov. de la Loja y El Oro, Ecuador. Baltimore, Tawson State University. Presentado a: Subcomisión ecuatoriana, Quito, 39p.

SKELTON, P.W., SPICER, R.A., KELLEY, S.P., GILMOUR, I. 2003. The Cretaceous World. Cambridge University Press, Cambridge, 360 p.

SLOAN, L.C., BARRON, E.J. 1990. "Equable" climates during Earth history. Geology 18: 489-492.

SMITH, S.Y., COLLINSON, M.E., RUDALL, P.J., SIMPSON, D.A., MARONE, F., STAMPANONI, M. 2009. Virtual taphonomy using synchrotron tomographic microscopy reveals cryptic features and internal structure of modern and fossil plants. Proceedings of the National Academy of Sciences (PNAS) 106: 1201312018.

SPICER, R.A. 1990. Reconstructing high-latitude Cretaceous vegetation and climate: Arctic and Antarctic compared. In: Taylor, T.N., Taylor, E.L., (eds). Antarctic Paleobiology, its Role in the Reconstruction of Gondwana. Springer-Verlag, New York, pp. 27-36.

SRIVASTAVA, S.K. 1994. Evolution of Cretaceous phytogeoprovinces, continents and climates. Review of Palaeobotany and Palynology 82: 197-224. 
STOCKEY, R.A. \& ROTHWELL, G.W. 2003. Anatomically preserved Williamsonia (Williamsoniaceae): evidence for bennettitalean reproduction in the late Cretaceous of western North America. International Journal of Plant Sciences 164: 251- 262.

STOCKEY, R.A. 1977. Reproductive biology of Cerro Cuadrado (Jurassic) fossil conifers: Pararaucaria patagonica Wieland. American Journal of Botany 65: 734-746.

STOLL, H.M., SCHRAG D.P. 1996. Glacial control of rapid sea level changes in the Early Cretaceous. Science 272: 1771-1774.

STOPES, M.C. 1912. Petrifactions of the Earliest European Angiosperms. Philosophical Transactions of the Royal Society B203: 75-10.

SUCERQUIA, P.A., 2006. Gimnospermas Eocretáceas da Formação Crato, Bacia do Araripe, Nordeste do Brasil. Dissertação de Mestrado, 108 p.

SUN, G., D. D. L. DILCHER, H. WANG, AND Z. CHEN. 2011. A eudicot from the Early Cretaceous of China. Nature. 471: 625-628.

SUN, G., DILCHER, D.L., ZHENG, S., ZHOU, Z. 1998. In search of the first flower: a Jurassic angiosperm, Archaefructus, from northeast China. Science 282: 16921695.

SUN, G., JI, Q., DILCHER, D., ZHENG, S., NIXON, K., WANG, X. 2002. Archaefructaceae, a new basal angiosperm family. Science 296 (5569): 899-904.

SUTTON, M.D. 2008. Tomographic techniques for the study of exceptionally preserved fossils. Proceedings of the Royal Society of London B 275: 1587-1593.

TAKHTAJAN, A.L. 1969. Flowering Plants, origin and dispersal. Ed. Smithsonianan Institution, Washington, $310 \mathrm{p}$.

TARDUNO, J.A., BRINKMAN, D.B. RENNE, P.R., COTTRELL, R.D., SCHER, H. \& CASTILLO, P. 1998. Evidence for extreme climatic warmth from Late Cretaceous Arctic Vertebrates. Science 282: 2241-2244.

TAYLOR D.W., HICKEY, L.J. 1990. An Aptian plant with attached leaves and flowers: implications for angiosperms origin. Science 247: 702-704.

TAYLOR, T.N., TAYLOR, E.L. \& KRINGS, M. 2009. Paleobotany: the biology and evolution of fossil plants. Boston, Academic Press, Elsevier, $1230 \mathrm{p}$.

TOUSSAINT, J.F., 1993. Evolución geológica de Colombia - Precámbrico y Paleozoico. Universidad Nacional de Colombia. Medellín, 229 p. 
TOUSSAINT, J.F., 1996. Evolución geológica de Colombia - Cretácico. Universidad Nacional de Colombia. Medellín, 277 p.

TRAVERSO, N.E., 1966. Brachyphyllum tigrense, nueva conífera de la Formación Baqueró, Cretácico de Santa Cruz. Ameghiniana 4, 189-194.

VAKHRAMEEV, V.A. 1991. Jurassic and Cretaceous floras and climates of the Earth. Cambridge University Press, Cambridge, 318 p.

VALDES, P.J., SELLWOOD, B.W., PRICE, G.D. 1996. Evaluating concepts of Cretaceous equability. Palaeoclimates 1 (2): 139-158.

VAN WAVEREN, I.M., VAN KONIJNENBURG-VAN CITTERT, J.H.A., VAN DER BURGH, J., DILCHER, D.L. 2002. Macrofloral remains from the Lower Cretaceous of the Leiva Region. Scripta Geologica 123: 2-39.

VIANA, CF., GAMA, E.G., Jr., SIMÕES, A., MOURA, J.A., FONSECA, J.R., ALVES, RJ. 1971. Revisão estratigráfica da Bacia Recôncavo/ Tucano. Boletim Técnico PETROBRÁS 146: 157-192.

VILLAR DE SEOANE, L. 1995. Estudio cuticular de nuevas Bennettitales eocretácicas de Santa Cruz, Argentina. In: VI Congreso Argentino de Paleontología y Bioestratigrafía. Actas del VI Congreso Argentino de Paleontología y Bioestratigrafía, pp. 247-254.

VILLAR DE SEOANE, L., 1996. Estudio morfológico de helechos fértiles hallados en la Formación Baqueró (Cretácico Inferior), provincia de Santa Cruz, Argentina. Revista Española de Paleontología 11, 83-90.

VILLAR DE SEOANE, L., 1997. Estudio cuticular comparado de nuevas Cycadales de la Form. Baqueró (Cretácico Inferior), provincia de Santa Cruz, Argentina. Revista Española de Paleontología 12, 129-140.

VILLAR DE SEOANE, L., 1999. Otozamites ornatus sp. nov., a new bennettitalean leaf species from Patagonia, Argentina. Cretaceous Research 20: 499-506.

VILLAR DE SEOANE, L., 2001. Cuticular study of Bennettitales from the Springhill Formation, Lower Cretaceous of Paragonia, Argentina. Cretaceous Research 22 461479.

VILLAR DE SEOANE, L., 2005. Equisetites pusillus sp. nov. from the Aptian of Patagonia, Argentina. Revista del Museo Argentino de Ciencias Naturales 7, 4349.

WALTON, J. 1928. A method of preparing sections of fossil plants contained in coal balls or in other types of petrifaction. Nature 122 (3076): 571. 
WANG, X., REN, D., WANG, Y. 2000. First discovery of angiospermous pollen from Yixian Formation in Western Liaoning. Acta Geologica Sinica 74 (3): 266-272.

WATSON, J., 1988. The Cheirolepidiaceae. In: Beck, C.B., (Ed.), Origin and evolution of the Gymnosperms. Columbia University Press, New York, pp. 382-447.

WEBER, M.B.I., TARNEY, J., KEMPTON, P.D., KENT R.W., 2002. Crustal make-up of the northern Andes: evidence based on deep crustal xenolith suites, Mercaderes, SW Colombia. Tectonophysics 345, 49-82.

WEISSERT, H., LINI, A., FÖLLMI, K.B., KUHN, O. 1998. Correlation of Early Cretaceous carbon isotope stratigraphy and platform drowning events: a possible link? Palaeogeography, Palaeoclimatology, Palaeoecology, 137: 189-203.

WHEELER, E.A. \& LEHMAN, T.M. 2005. Cretaceous - Paleocene conifer woods from Big Bend National Park, Texas. Palaeogeography, Palaeoclimatology, Palaeoecology 226: 233-258.

WIGNALL, P.B. 2001. Large igneous provinces and mass extinctions. Earth Science Reviews 53: 1-33.

WING, S.L., BOUCHER, L.D. 1998. Ecological aspects of the Cretaceous flowering plant radiation. Annual Reviews of Earth and Planetary Science 26: 379-421.

WISSLER, L., FUNK, H., WEISSERT, H. 2003. Response of Early Cretaceous carbonate platforms to changes in atmospheric carbon dioxide levels. Palaeogeography, Palaeoclimatology, Palaeoecology, 200: 187-205.

ZIEGLER, A.M., RAYMOND, A., GIERLOWSKI, T.C., HORRELL, M.A., ROWLEY, D.B., AND LOTTES, A.L. 1987. Coal, climate and terrestrial productivity: the Present and Early Cretaceous compared. In: Scott, A.C. (ed.) Coal and coal-bearing strata: Recent Advances. Geological Society of London Special Publication No. 32, pp. 25-50. 


\section{PRANCHA 1}

\section{Araucaria sp.1.}

Megastróbilos elipsoidais alongados com diferentes tipos de preservação exibindo pedúnculo largo e robusto e complexos bráctea-escama inseridos em filotaxia helicoidal.

A. Espécime GP/3E 9383. Preservado como incarbonização em corte longitudinal mostrando parte do interior do eixo onde podem ser observados numerosos canais aparentemente resiníferos.

B. Espécime SM.B.16595. Preservado como impressão da parte externa e com alguns fragmentos de óxidos de ferro.

C. Espécime Mb.Pb.2002/1049. Preservado como incarbonização em corte longitudinal mostrando parte do interior do eixo onde podem ser observados numerosos canais aparentemente resiníferos que seguem até atingirem os complexos bráctea-escama.

D. Espécime MPSC PL2105. Preservado como impressão da parte externa e com fragmentos de charcoal. Este espécime é o que apresenta o maior comprimento dos observados, $22 \mathrm{~cm}$.

E. Espécime 3617. Preservado como impressão da parte externa. Este espécime apresenta o maior comprimento do pedúnculo, $4,5 \mathrm{~cm}$.

F. Detalhe do espécime 3617 mostrando a base do cone em contato com o pedúnculo e a cobertura de brácteas. 

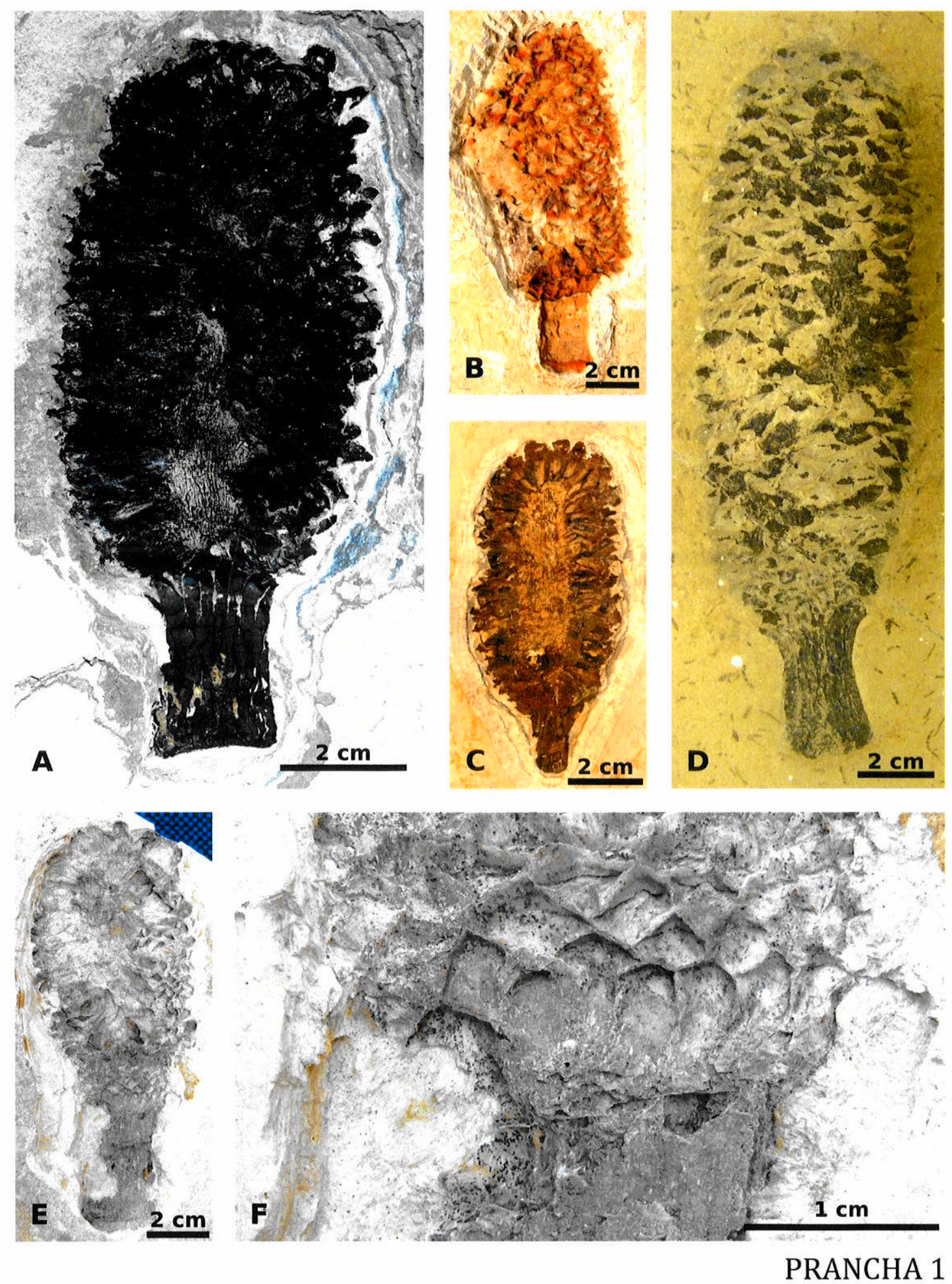


\section{PRANCHA 2}

\section{Araucaria sp.1.}

A. Espécime 3618. Megastróbilo preservado como impressão da parte externa e com alguns fragmentos de óxidos de ferro, exibindo pedúnculo largo e complexos bráctea-escama.

B. Detalhe do espécime 3617 mostrando complexos bráctea-escama de contorno obovado em conexão.

C. Espécime GP/3E9091. Complexo bráctea-escama isolado preservado como impressão, com contorno obovado.

D. Espécime MPSC PL 651. Complexo bráctea-escama isolado preservado em oxidos de ferro, com contorno obovado. Na parte inferior das duas margens podem ser observadas numerosas fibras. 

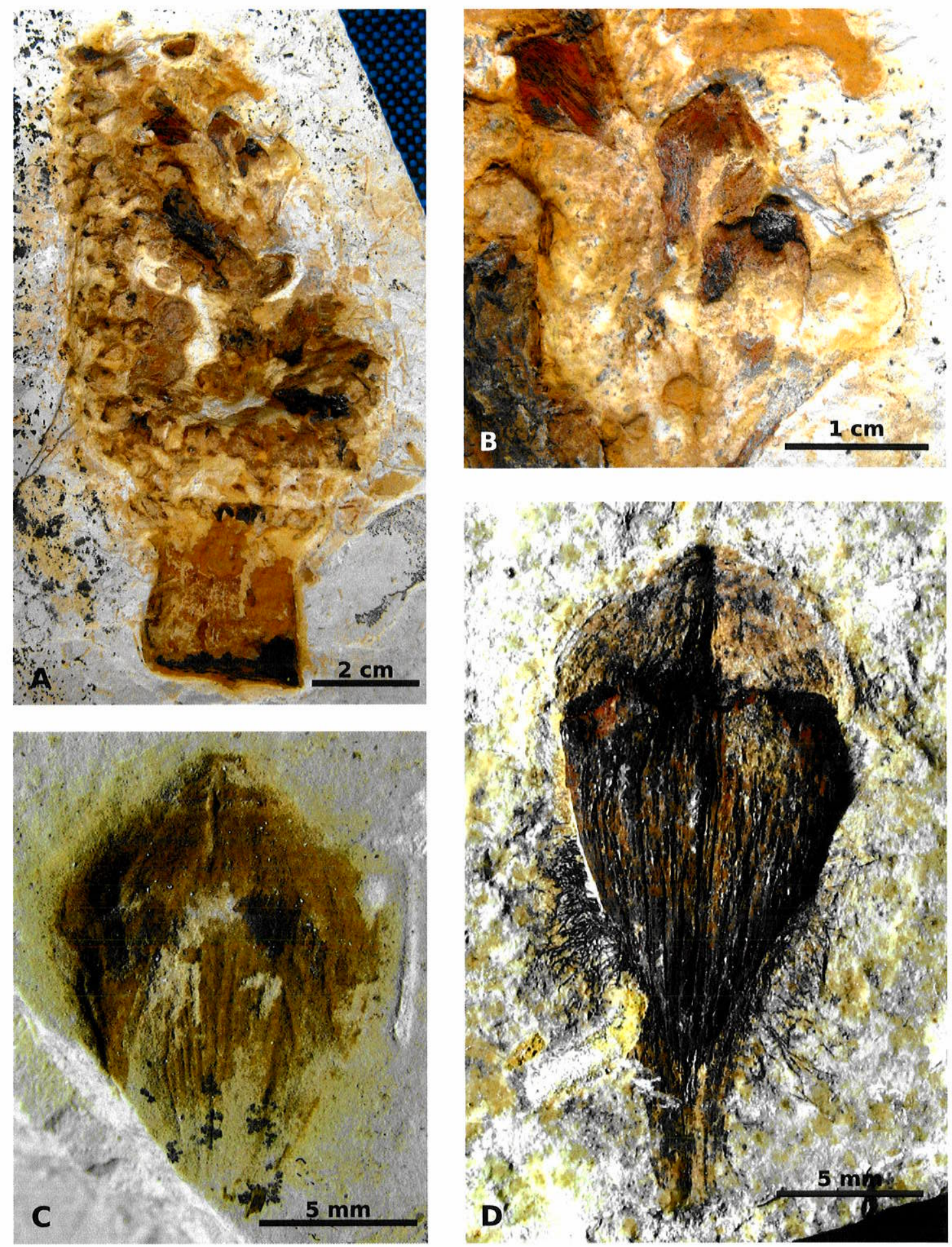

PRANCHA 2 


\section{PRANCHA 3}

\section{Araucaria sp. 2}

A. Espécime Mb.Pb.1997/1275. Megaestróbilo tridimensional preservado em óxidos de ferro, de contorno elipsoidal achatado, côncavo na base, sem pedúnculo. Mostra desde o exterior complexos bráctea-escama densamente empacotados em filotaxia helicoidal. A superfície se apresenta desgastada.

B. Detalhe do espécime Mb.Pb.1997/1275 mostrando um complexo brácteaescama sem a porção apical, onde podem ser diferenciados a semente $(s)$, a escama ovulífera $(e o)$ e a bráctea $(b)$.

C. Imagem de microtomografia computadorizada do espécime Mb.Pb.1997/1275 mostrando o interior das sementes.

D. Imagem de microtomografia computadorizada do espécime Mb.Pb.1997/1275 em vista lateral onde pode ser observado o achatamento que sofreu o cone. 

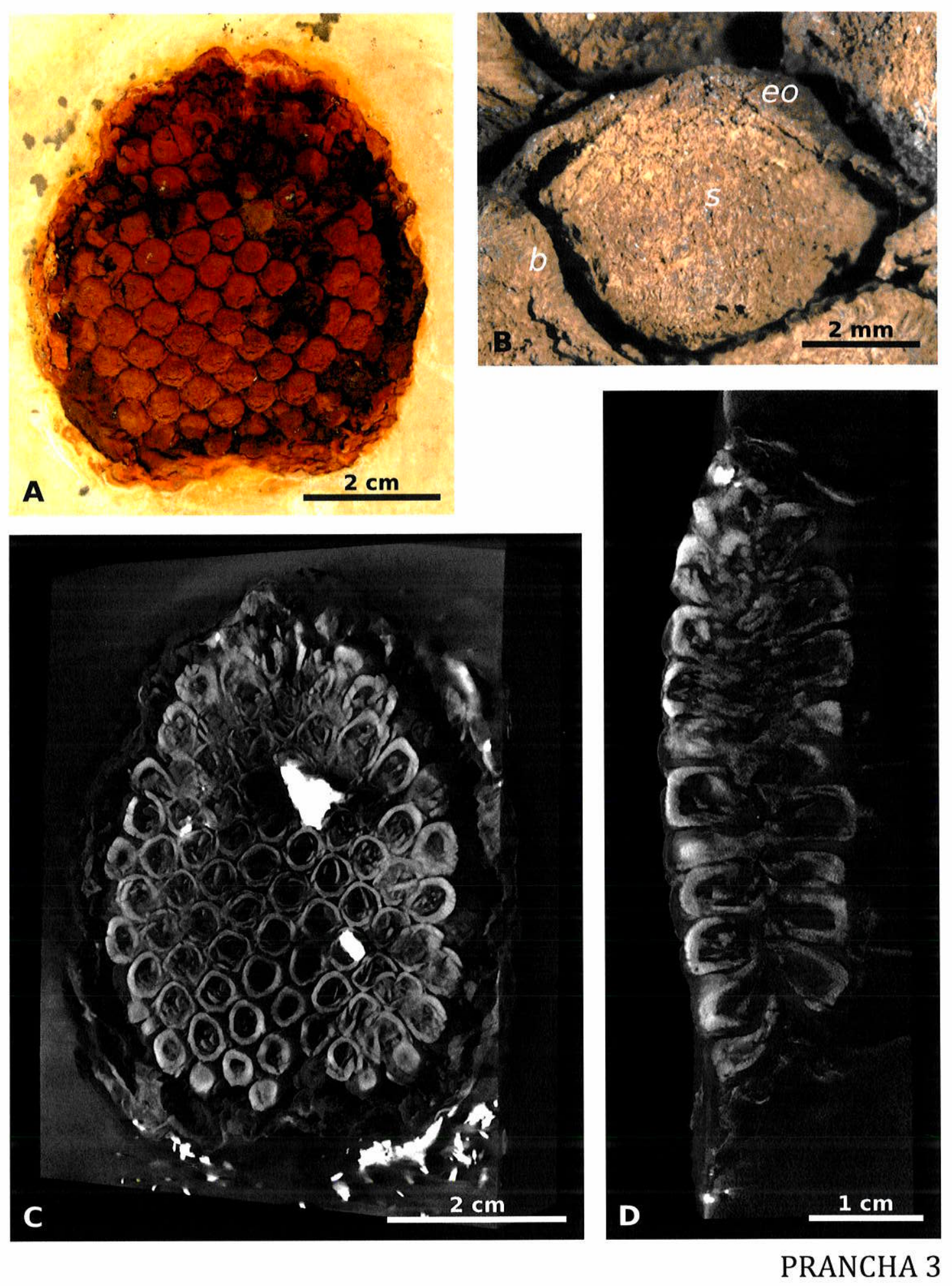


\section{PRANCHA 4}

\section{Araucaria sp. 2}

A. Espécime Mb.Pb.1997/1277. Megaestróbilo tridimensional preservado em óxidos de ferro, de contorno elipsoidal achatado, côncavo na base, sem pedúnculo. Mostra desde o interior complexos bráctea-escama, onde podem ser diferenciados a semente $(s)$, a escama ovulífera $(e o)$ e a bráctea $(b)$.

A. Detalhe do espécime Mb.Pb.1997/1277 mostrando vista lateral dos complexos bráctea-escama.

B. Imagem de microtomografia computadorizada do espécime Mb.Pb.1997/1277 em vista lateral onde pode ser observado o achatamento que sofreu o cone.

C. Imagem de microtomografia computadorizada do espécime Mb.Pb.1997/1277 mostrando o interior das sementes e revelando a parte apical dos complexos bráctea-escama que não é observável na Figura A. 

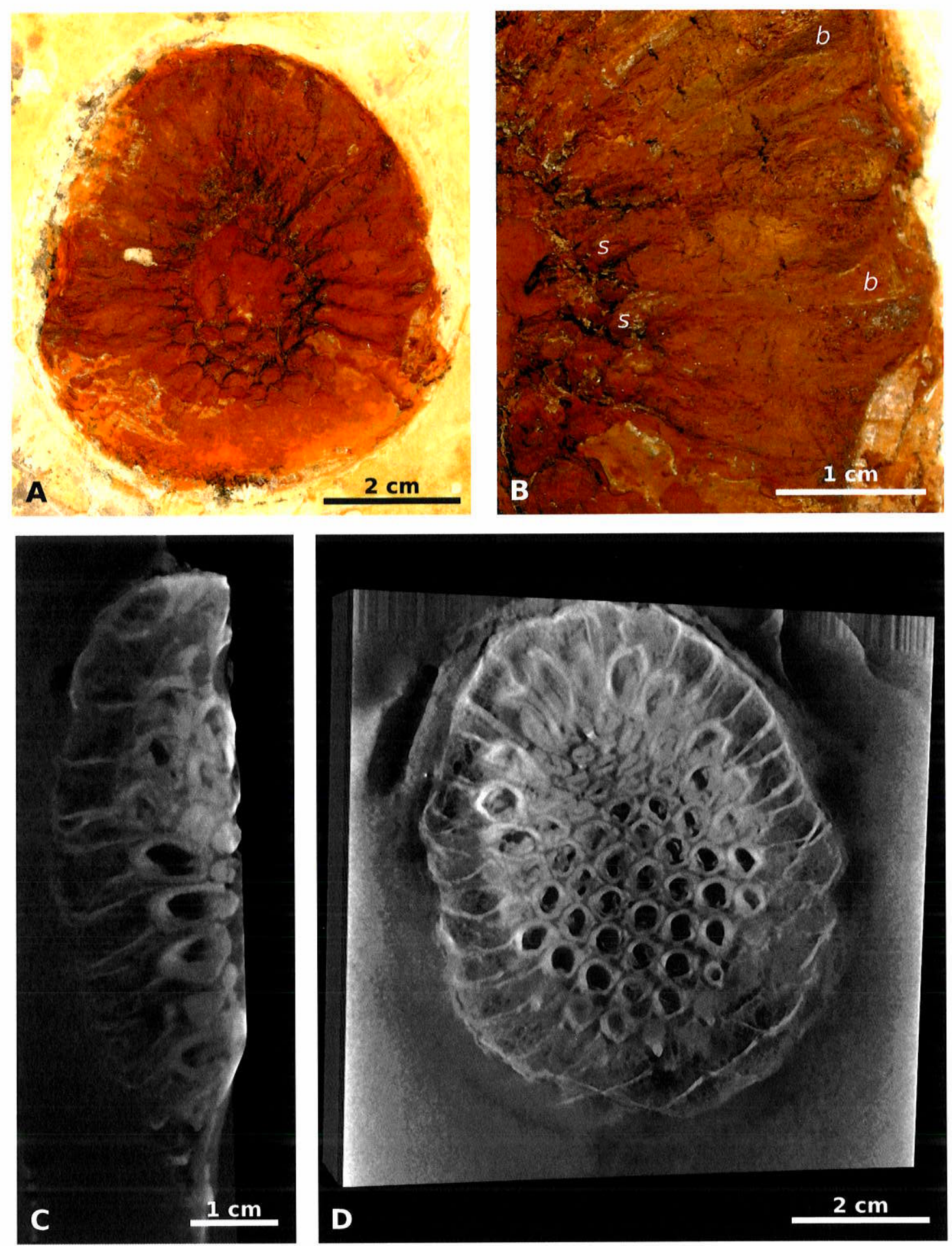

PRANCHA 4 


\section{PRANCHA 5}

\section{Araucaria sp. 2}

A. Espécime Mb.Pb.2002/1340. Megaestróbilo com preservação tridimensional em charcoal, de contorno cordiforme, com pedúnculo curto, visto desde o exterior.

B. Espécime 3619. Megaestróbilo com preservação tridimensional em charcoal, de contorno arredondado, com pedúnculo curto e sem a porção mais apical, visto desde o exterior.

C. Espécime UFRJ 1129Pb. Fragmento de megaestróbilo preservado em óxidos de ferro, mostrando vários complexos bráctea-escama em conexão e de morfologia semelhante a Araucaria duarteae.

D. Espécime UFRJ348Pb. Megaestróbilo com preservação tridimensional em óxidos de ferro, de formato arredondado e sem evidencia de achatamento. A porção mais apical dos complexos bráctea-escama, não está preservada, podendo observar diretamente as sementes em distribuição helicoidal.

E. Espécime 3620. Megaestróbilo com preservação tridimensional em óxidos de ferro, de contorno arredondado, com pedúnculo curto, visto em corte longitudinal.

F. Espécime SM.B.16438. Megaestróbilo com preservação tridimensional em óxidos de ferro. Mostrando o eixo desprovisto de complexos bráctea-escama na maior parte do seu comprimento, restando apenas os da parte basal. 

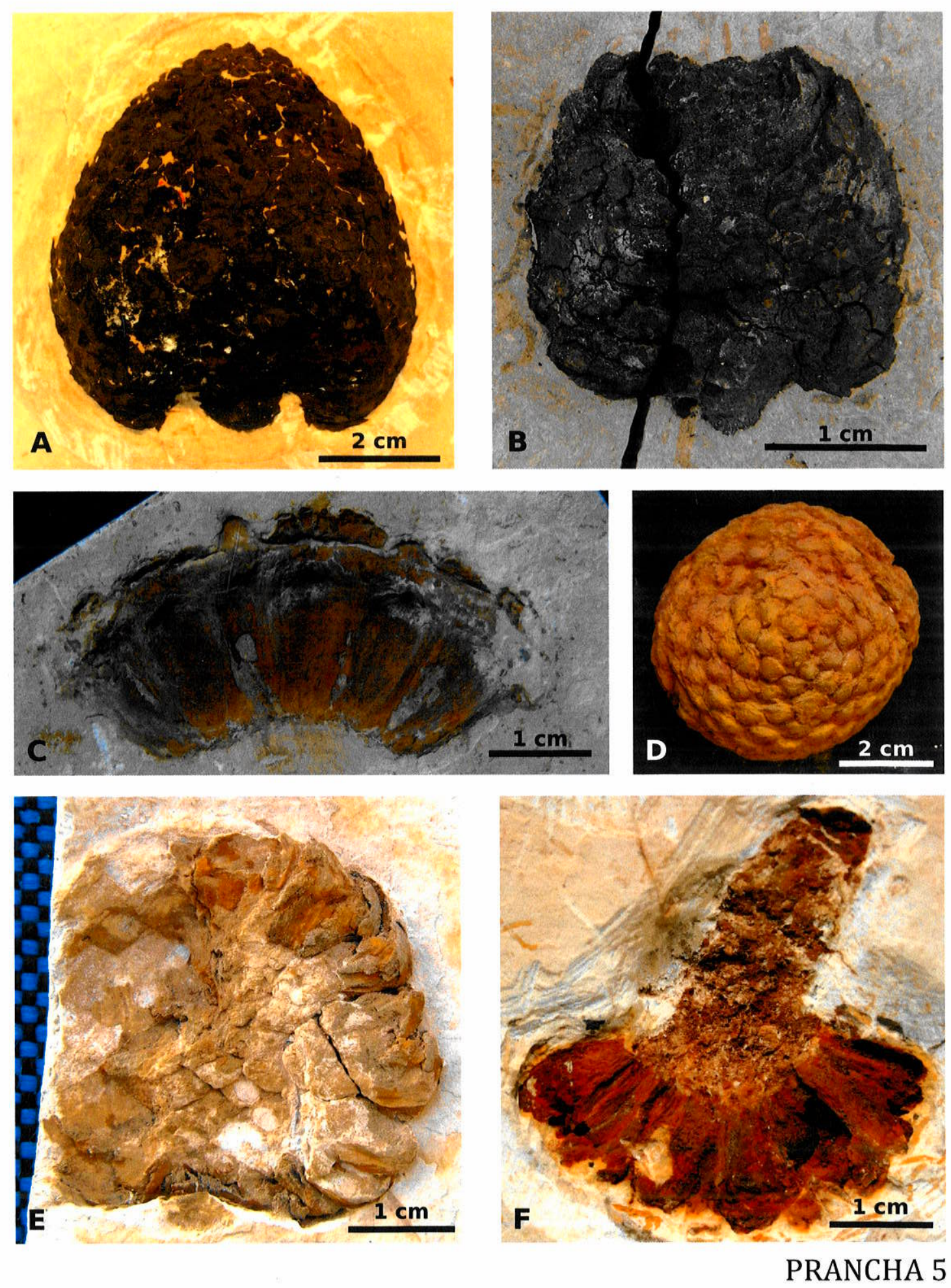


\section{PRANCHA 6}

\section{Araucariostrobus sp. 1}

Microstróbilos preservados em óxidos de ferro de formato elipsoidal e com pedúnculo longo. Os microesporófilos se inserem em filotaxia helicoidal e são caducos começando a partir da porção apical.

A. Espécime SM.B.16431. Preservado em corte longitudinal, ainda apresenta microesporófilos.

B. Espécime 3621. Preservado em corte longitudinal, ainda apresenta microesporófilos.

C. Espécime Mb.Pb.2002/855a-b. Totalmente desprovisto de microesporófilos, mostra as marcas de inserção dos mesmos no eixo e um pedúnculo longo.

D. Espécime Mb.Pb.2001/1398a-b. Preservado como impressão da parte externa mostra a disposição dos microesporófilos de forma helicoidal,

E. Espécime Mb.Pb.1998/483. Totalmente desprovisto de microesporófilos, mostra apenas o contorno elipsoidal do eixo e um pedúnculo curto. 

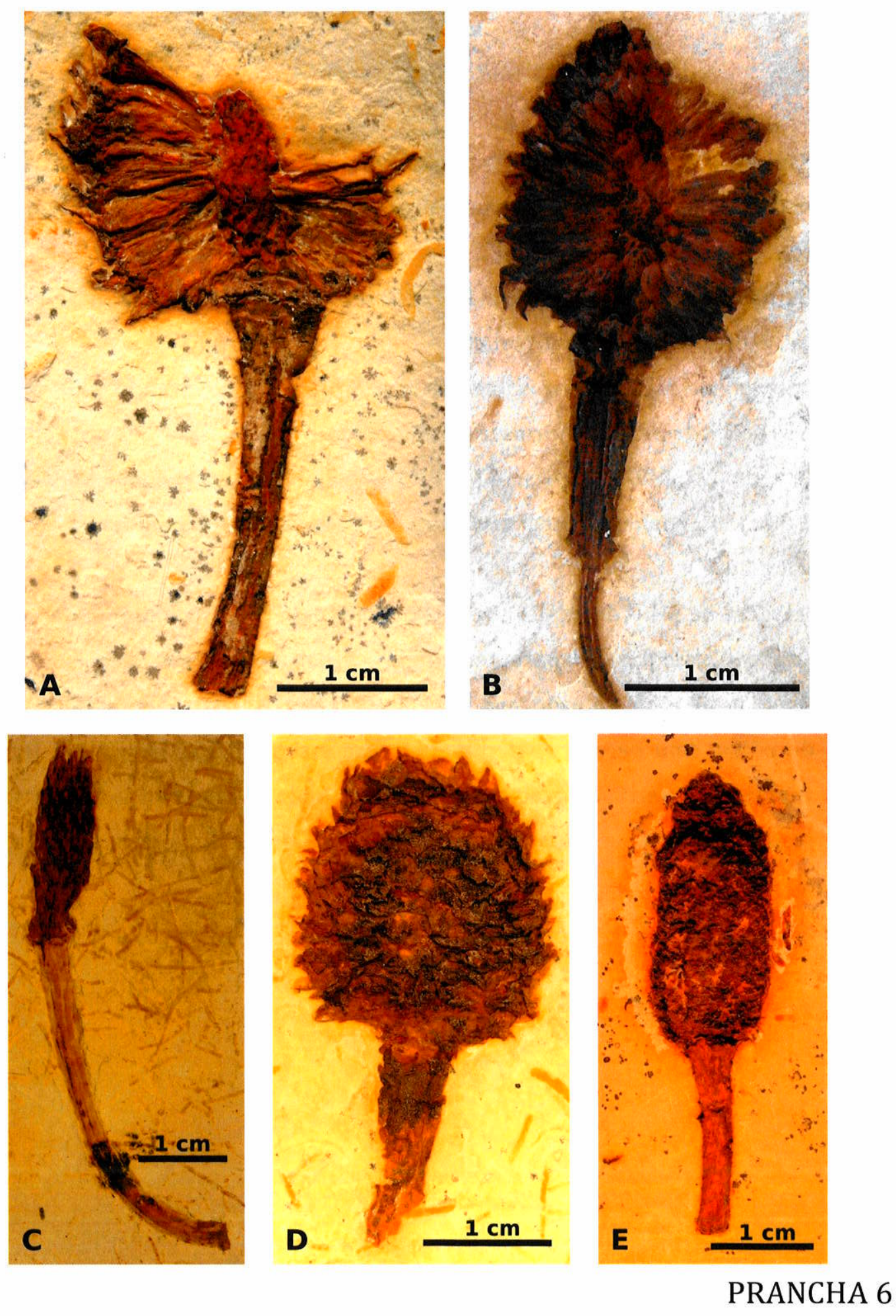


\section{PRANCHA 7}

\section{Araucariostrobus sp. 2}

A. Espécime Mb.Pb.1999/2297b. Microestróbilo preservado em óxidos de ferro, mostrado em corte longitudinal. Apresenta o eixo central e os microesporófilos com brácteas longas e finas.

B. Detalhe do espécime Mb.Pb.1999/2297b (quadrado) mostrando pequenas estruturas arredondadas (setas).

C. Imagem de MEV do espécime Mb.Pb.1999/2297b mostrando uma fileira de três grãos de pólen de formato arredondado.

D. Imagem de MEV do espécime Mb.Pb.1999/2297b mostrando os grãos de pólen (setas) no meio de uma estrutura arredondada que poderia ser um saco polínico.

E. Imagem de MEV do espécime Mb.Pb.1999/2297b mostrando detalhe do grão de pólen, com parede aparentemente lisa e sem aberturas visíveis.

F. Imagem de MEV do espécime Mb.Pb.1999/2297b mostrando detalhe do grão de pólen, com parede aparentemente lisa e sem aberturas visíveis. Na parte superior esquerda do grão de pólen (seta) pode se observar o que parece ser resto de uma camada mais externa do grão de pólen, com alguma ornamentação. 

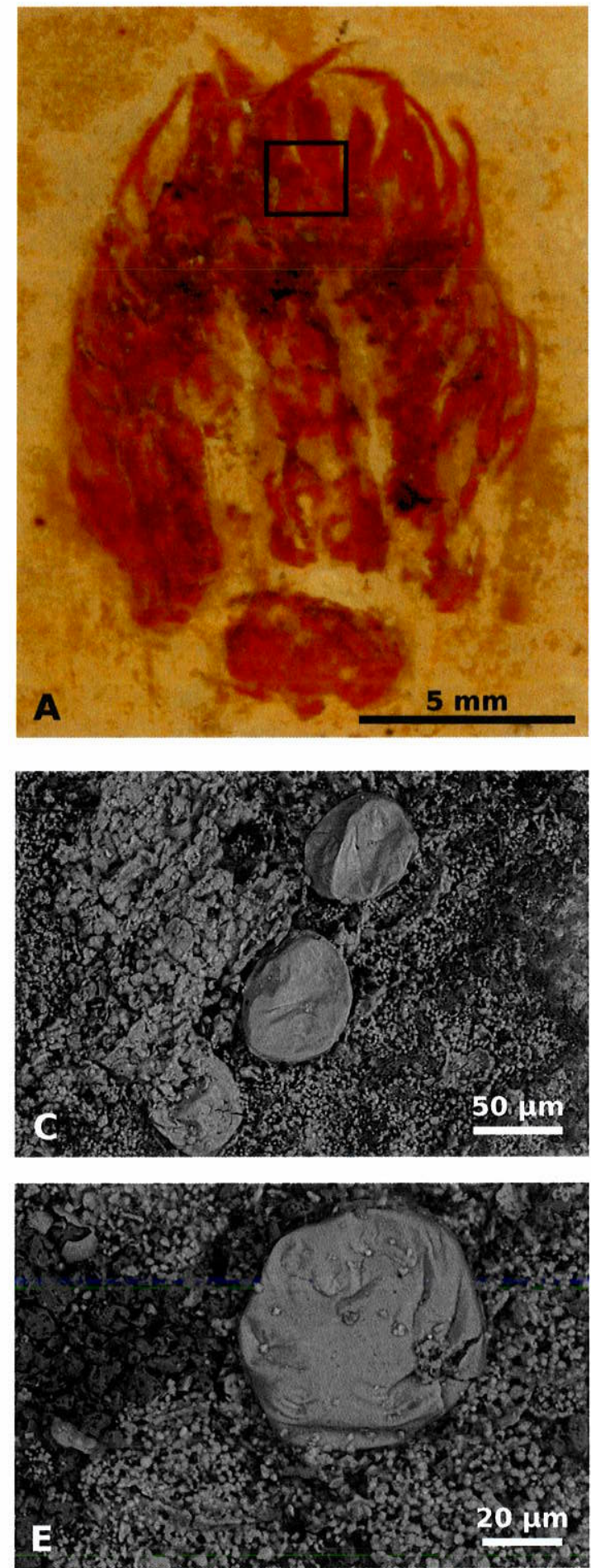
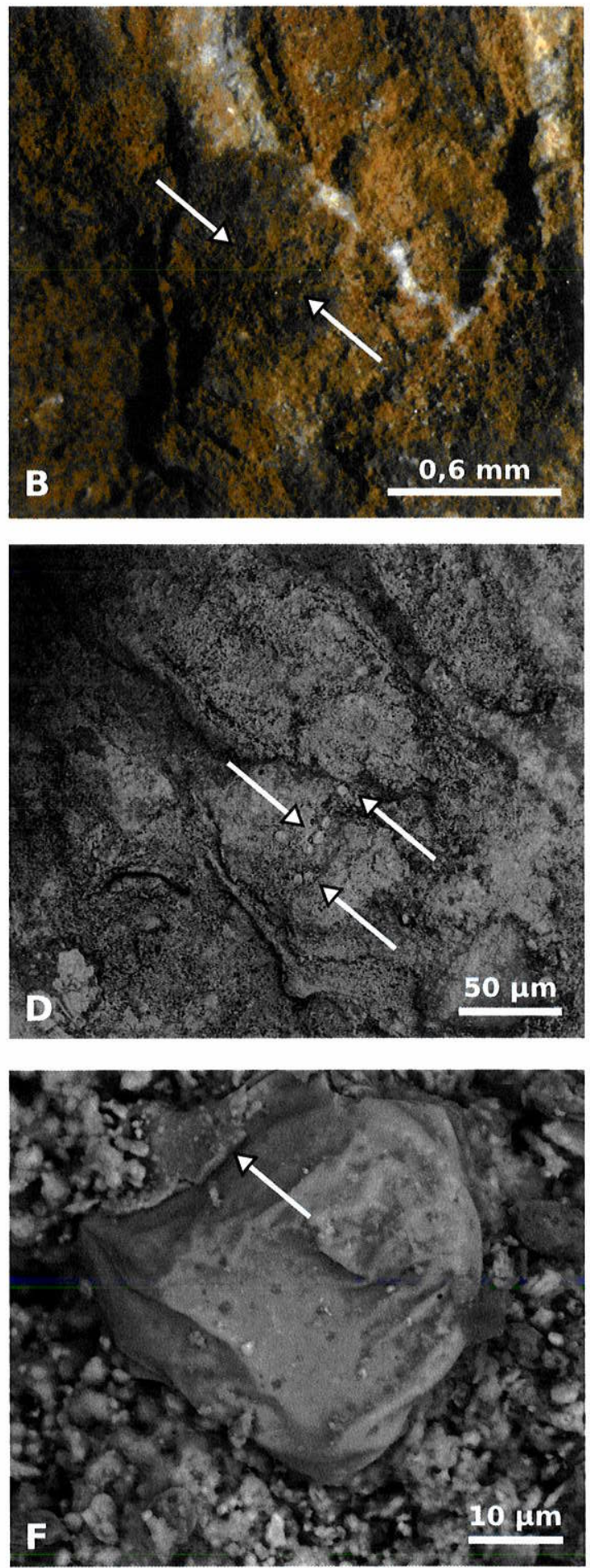

PRANCHA 7 


\section{PRANCHA 8}

\section{Brachyphyllum obesum Heer}

Espécimes preservados em óxidos de ferro compostos por ramos de até três ordens em conexão, densamente cobertos por folhas escamiformes de contorno rômbico, aspecto coriáceo, imbricadas e adpressas, dispostas em filotaxia helicoidal. Os ramos mais proximais são de crescimento monopodial, aparentemente silépticos, enquanto os outros têm crescimento palagiotrópico, com simetria dorsiventral e filotaxia suboposta. Os ângulos de inserção, tanto para os ramos de posição intermediária, quanto para os ramos distais, variam de $36^{\circ}$ 59으, com maior frequência de 57ํ. Os ramos mais proximais possuem comprimento variável e largura / diâmetro de 0,7-0,9 mm, com folhas e 0,3-0,4 mm de diâmetro, sem folhas. Os ramos de posição intermediária possuem comprimento de 2,2-3,0 mm e largura/ diâmetro de 0,5-1,10 mm, com folhas e largura/ diâmetro de 0,2-0,3 mm, somente o caule. Os ramos mais distais possuem 0,6-0,2 mm de comprimento e 0,4-0,9 mm de largura com folhas. As folhas são, ligeiramente, assimétricas e estão inseridas em filotaxia helicoidal de 2/5, predominantemente. As folhas medem $0,36-0,62 \mathrm{~mm}$ de largura por $0,27-0,52 \mathrm{~mm}$ de comprimento, com proporção de 1:1,1-1:1,47, menor nos ramos proximais aumentando gradativamente, nos ramos distais.
A. Espécime Mb.Pb.1999/451.
B. Espécime SM.B.16590.
C. Espécime SM.B.16587.
D. Espécime SM.B.16385.
E. Detalhe do espécime SM.B.16590. 

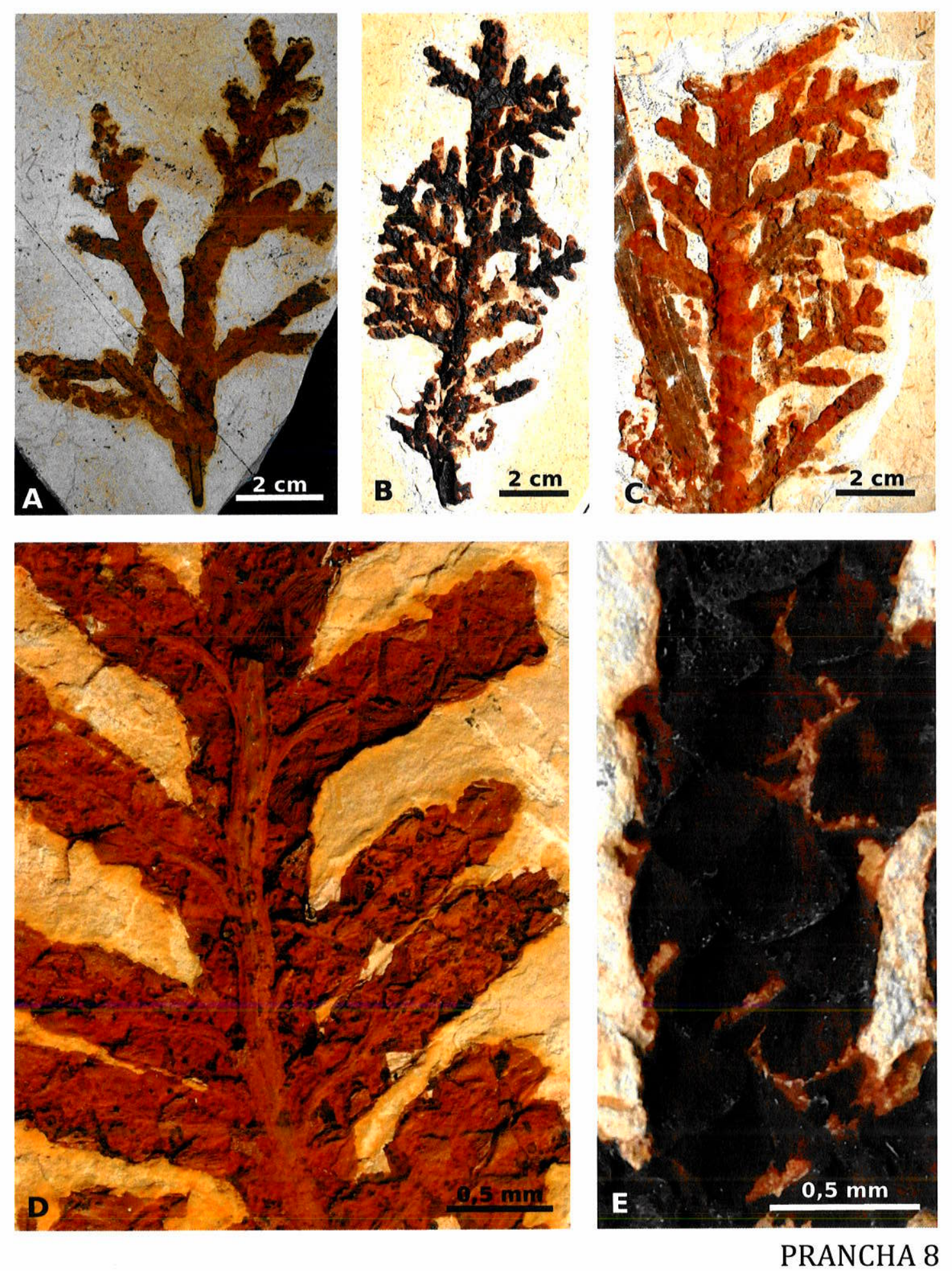


\section{PRANCHA 9}

\section{Brachyphyllum obesum Heer}

A. Espécime Mb.Pb. 1998/466. Epiderme de folha mostrando células epidérmicas ordinárias de contorno tetra- a pentagonal e áreas com dois valores modais, um de 0,39 - 0,52 mm2 e outro de 0.73 - 0,98 mm2. Os estômatos são afundados sem células subsidiarias diferenciadas das células epidérmicas ordinárias. Não foram observadas marcas de papilas ao redor da cavidade estomática

B. Espécime Mb.Pb. 1998/466. Na área apical das folhas, as células tornam-se mais alongadas. Muitas células epidérmicas apresentam marcas circulares (de papilas ou pêlos), de 9,0 - 15,3 $\mu$ m de diâmetro.

C. Espécime Mb.Pb. 1999/475a. Seção transversal do lenho com contorno elíptico, sem evidência de achatamento ou deformação durante a fossildiagênese. Apenas as traqueídes e alguns raios de parênquima estão preservados

D. Espécime Mb.Pb. 1999/475a. Seção transversal do lenho mostrando traqueídes dispostas em fileiras radiais, sem evidências de anéis de crescimento.

E. Espécime Mb.Pb. 1999/475a. Seção transversal do lenho mostrando o contorno das traqueídes, quadrangular arredondado, com diâmetros de 18 $26 \mu \mathrm{m}$.

F. Espécime Mb.Pb. 1999/475a. Seção transversal do lenho mostrando o que aparentemente seria um traço foliar ( $t$ f), com traqueídes em posição horizontal. 

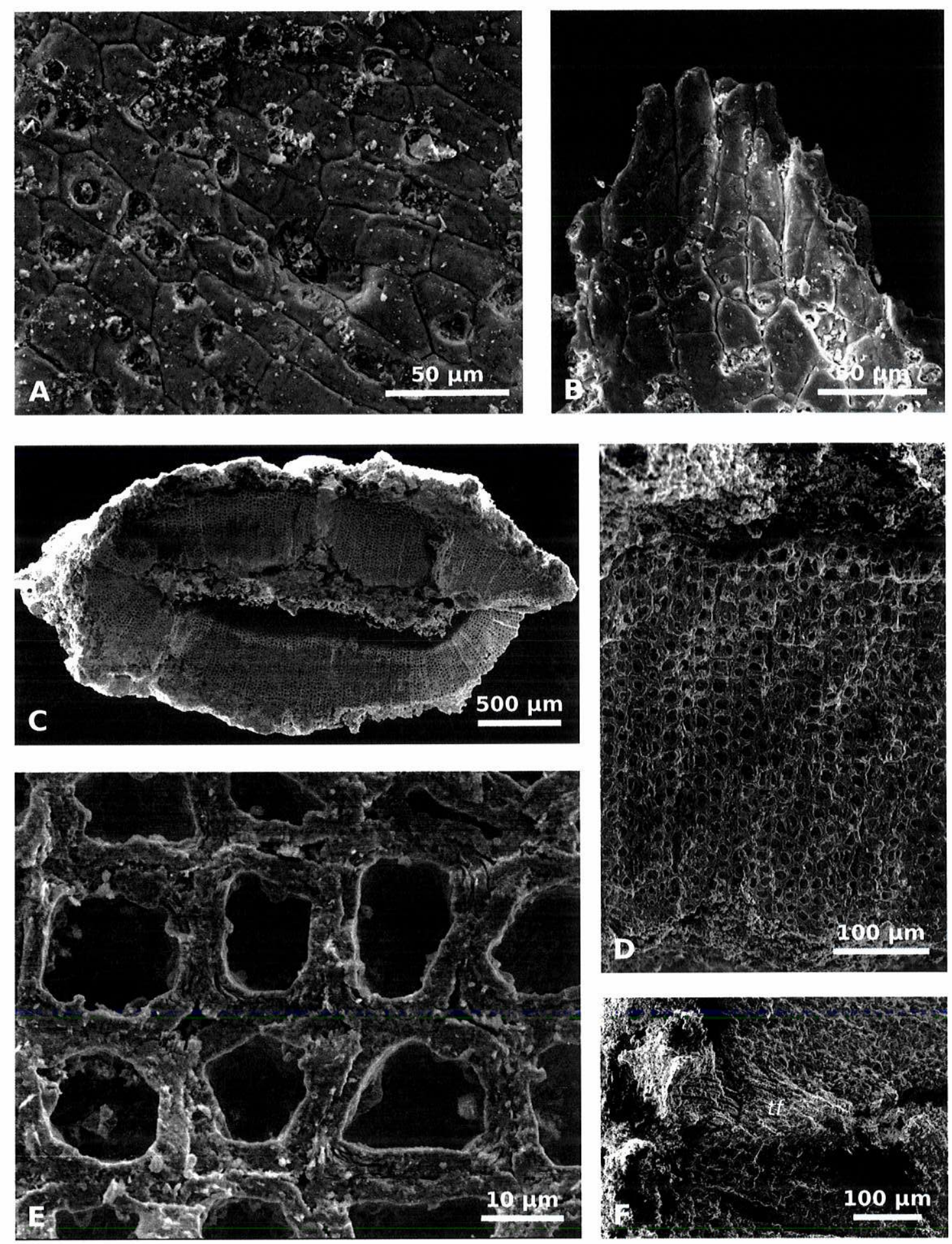

PRANCHA 9 


\section{PRANCHA 10}

\section{Brachyphyllum obesum Heer}

A. Espécime Mb.Pb. 1998/475b. Imagem de MEV de lenho em seção radial mostrando as paredes das traqueídes, com pontuações areoladas de contorno hexagonal, com 9-14 $\mu \mathrm{m}$ de diâmetro, apresentam-se uni e bisseriadas alternadas e sempre em contato, as vezes deformadas. A largura das traqueídes, nesta seção, varia de $15-30 \mu \mathrm{m}$.

B. Espécime Mb.Pb. 1998/475b. Imagem de MEV de lenho em seção radial mostrando pontuações areoladas de contorno hexagonal, bisseriadas alternadas em contato.

C. Espécime Mb.Pb. 1998/475b. Imagem de MEV de lenho em seção radial mostrando as paredes radiais das traqueídes, com pontuações areoladas de contorno hexagonal, uni e bisseriadas alternadas. Na parte superior e inferior do conjunto de pontuações das traqueídes podem ser observados campos de cruzamento $(c c)$.

D. Espécime Mb.Pb. 1998/475b. Imagem de MEV de lenho em seção radial mostrando campos de cruzamento com pontuações do tipo araucarioide, geralmente 11 por campo. Estas pontuações são de contorno circular mas por vezes, hexagonal, na maioria dos casos bisseriadas alternadas.

E. Espécime Mb.Pb. 1998/475b. Imagem de MEV de lenho em seção radial mostrando campos de cruzamento com pontuações do tipo araucarioide, geralmente 11 por campo. Estas pontuações são de contorno circular mas por vezes, hexagonal, na maioria dos casos bisseriadas alternadas.

F. Espécime Mb.Pb. 1999/451. Imagem de MEV de lenho em seção tangencial mostrando raios uniseriados e curtos, predominantemente com uma célula de profundidade, mas podendo ter até quatro. Não foram observadas pontuações nas paredes das traqueídes nem canais resiníferos. 

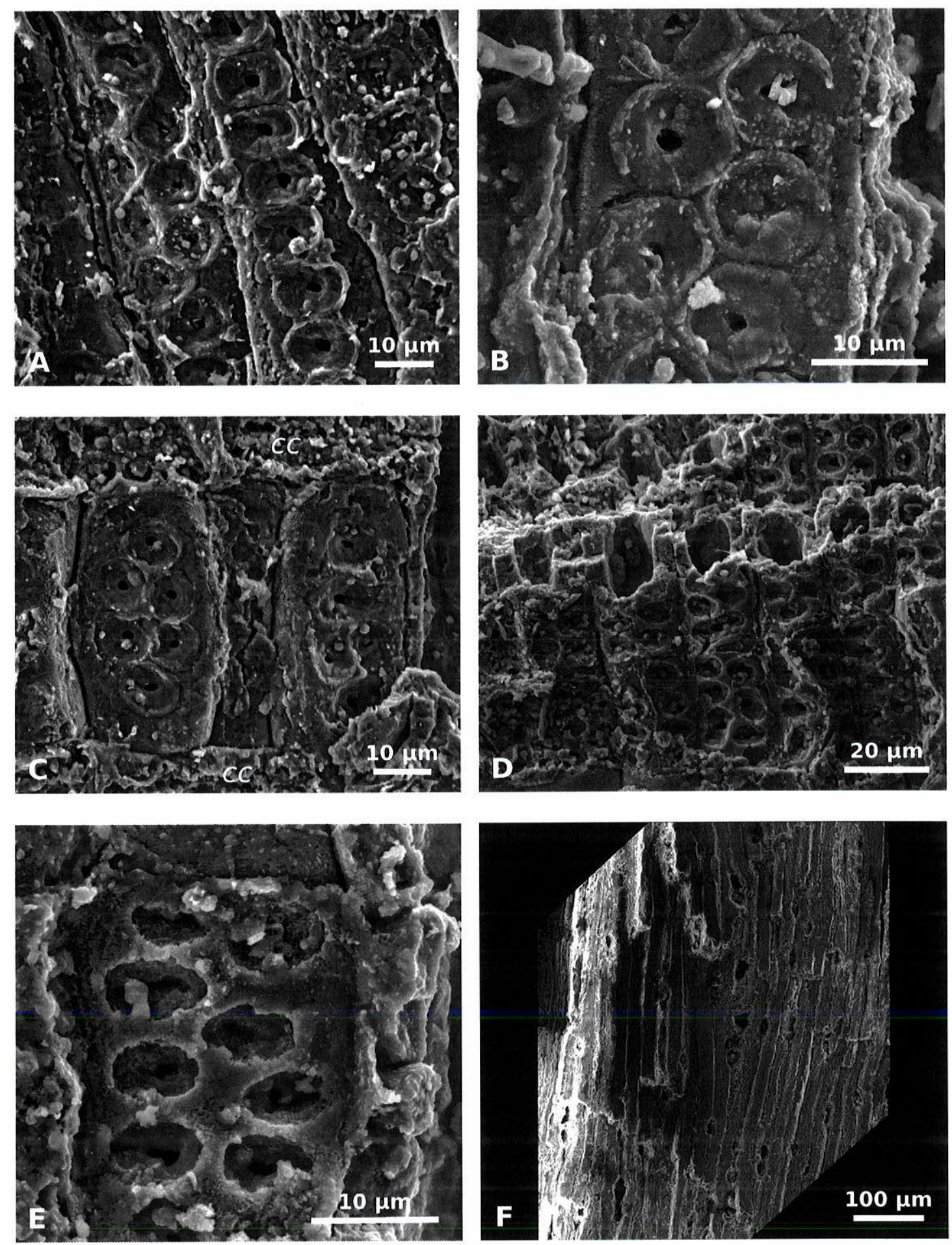

PRANCHA 10 


\section{PRANCHA 11}

A. Espécime Lp VL 0091. Ramo folhoso de Cupressinocladus lepidophyllus (Saporta) Lemoigne preservado tridimensionalmente, com ramificação de duas ordens em disposição planar suboposta. Coberto por folhas carnosas falcadas dispostas em filotaxia decussada.

B. Espécime 2169. Ramo folhoso de Cupressinocladus lepidophyllus (Saporta) Lemoigne preservado como impressão, com densa ramificação de duas ordens em disposição planar suboposta. Coberto por folhas carnosas falcadas dispostas em filotaxia decussada.

C. Espécime Lp VL 0003. Ramo folhoso de Cupressinocladus sutamarchensis (Huertas) van Waveren, van Konijnenburg-van Cittert, van der Burgh \& Dilcher preservado tridimensionalmente, com ramificação de duas ordens em disposição planar suboposta. Coberto por folhas carnosas de contorno rômbico dispostas em filotaxia decussada.

D. Espécime Lp VL 0016. Ramos folhosos de Frenelopsis sp., numerosos fragmentos de ramos articulados, exibindo duas folhas por nó (setas) e que envolvem completamente os entrenós.

E. Espécime Lp VL 0022. Ramos folhosos de Pseudofrenelopsis sp., fragmentos de ramos articulados, com entrenós curtos e uma única folha por nó, sempre do tipo aberto. 

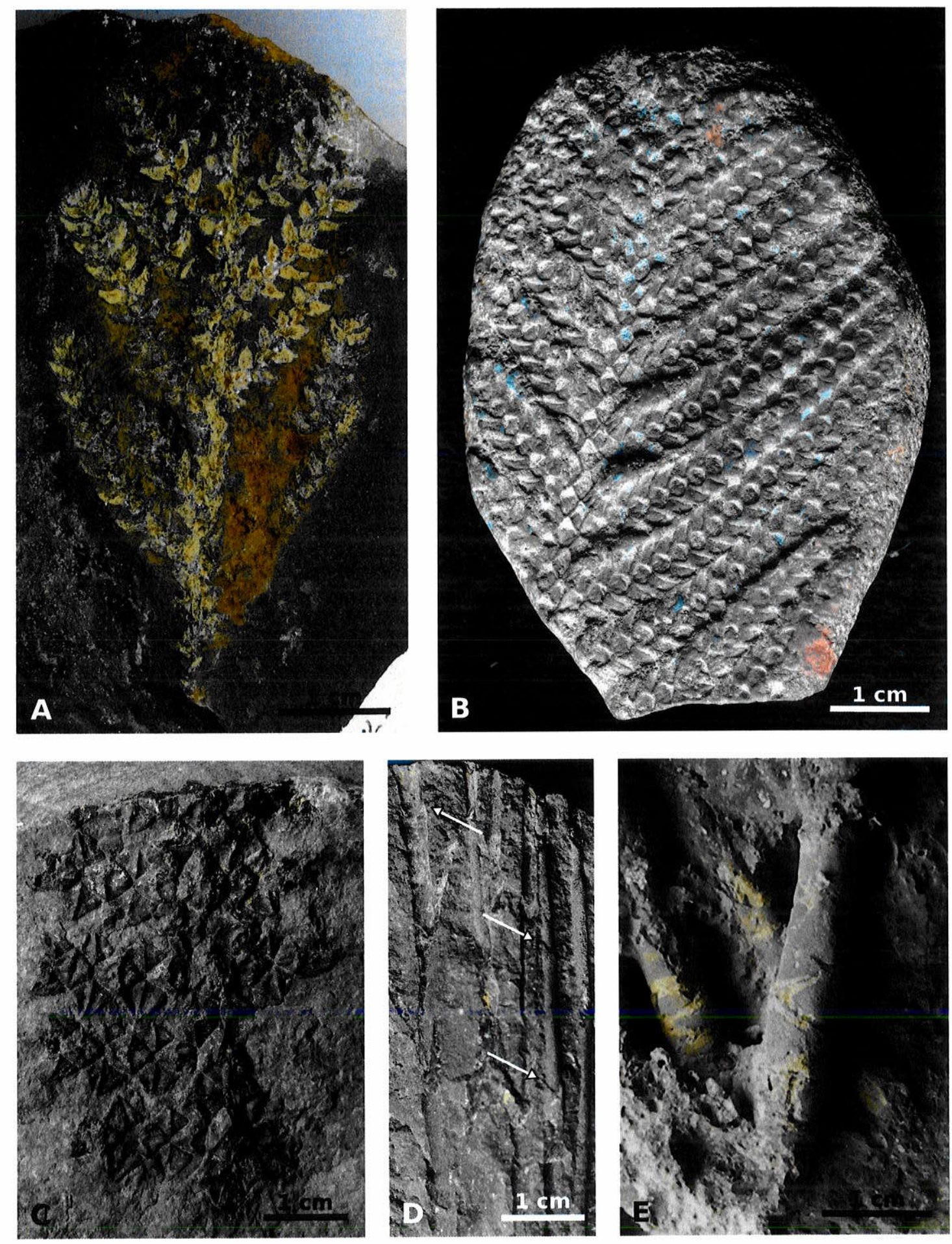

PRANCHA 11 


\section{PRANCHA 12}

A. Espécime Lp VL 0035. Megaestróbilo de Araucariostrobus creutzbergi Huertas em corte obliquo exibindo o eixo central e os complexos bráctea-escama com sementes obovadas $(s)$.

B. Espécime Lp VL 0035. Megaestróbilo de Araucariostrobus creutzbergi Huertas em corte longitudinal exibindo o eixo central e os complexos bráctea-escama com sementes obovadas $(s)$.

C. Espécime Lp VL 0007. Microestróbilo de Araucariostrobus camargoi Huertas visto do exterior e preservado incompleto, somente sua parte apical. Podem ser observados os microesporófilos dispostos em filotaxia helicoidal e brácteas largas na porção mais basal.

D. Espécime 180. Microestróbilo de Araucariostrobus camargoi Huertas em corte longitudinal exibindo o eixo central e os microesporófilos inseridos helicoidalmente, em ambos os lados da parte externa do microesporófilo podem se observar as brácteas $(b)$ que o cobrem até pelo menos $2 / 3$ do comprimento total. 


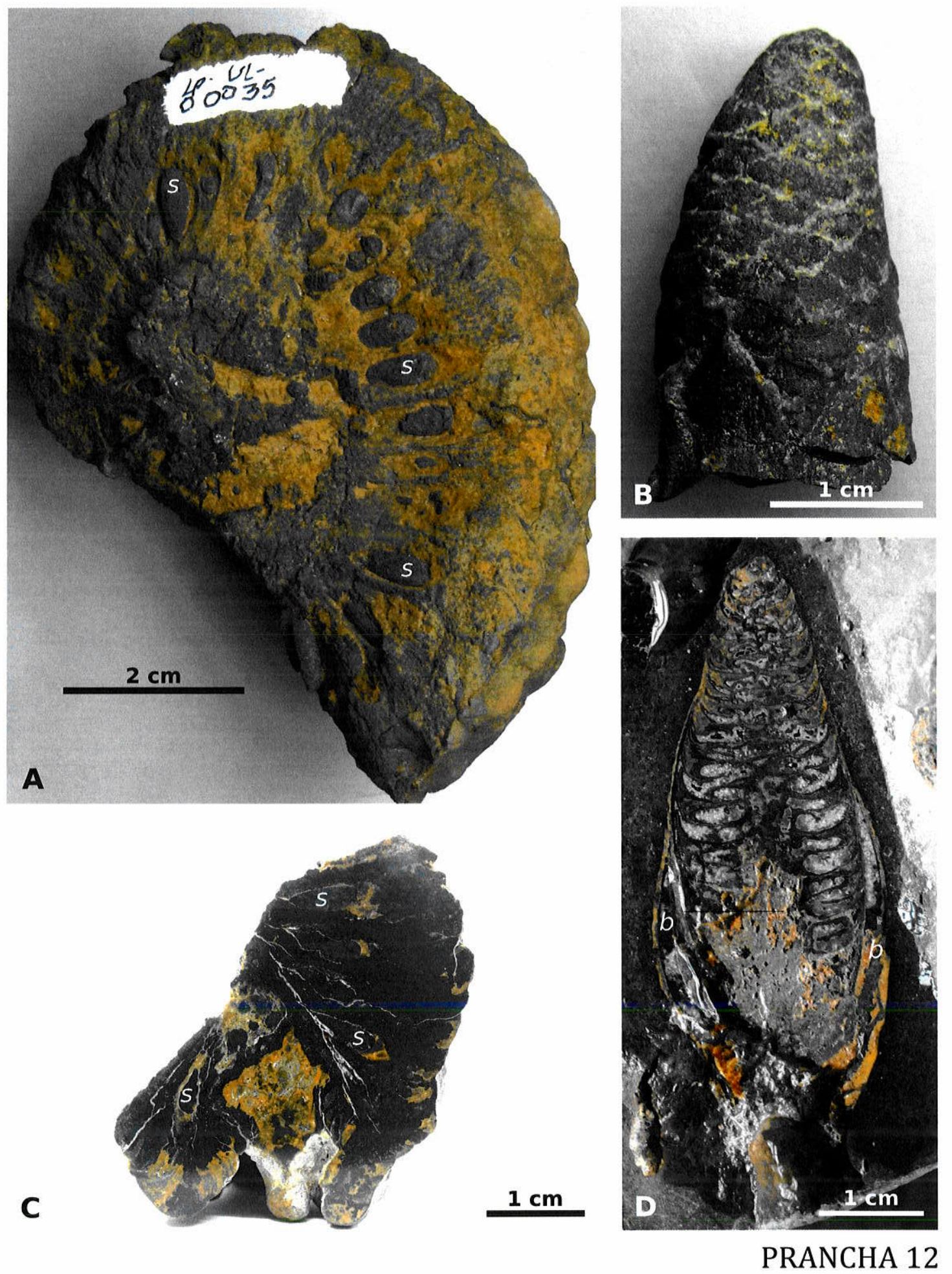




\section{PRANCHA 13}

A. Espécime Mb.Pb. 2004/0401. Microestróbilo preservado tridimensionalmente visto desde o seu exterior e ainda inserido na concreção.

B. Imagem de tomografia computadorizada do espécime Mb.Pb. 2004/0401. Microestróbilo de Araucariostrobus signatus Huertas mostrando um corte longitudinal tangencial onde podem ser vistos os microesporófilos ( $\mathrm{mi}$ ) dispostos em filotaxia helicoidal e as brácteas $(b)$ cobrindo-o até mais de $2 / 3$ do seu comprimento.

C. Imagem de tomografia computadorizada do espécime Mb.Pb. 2004/0401. Microestróbilo de Araucariostrobus signatus Huertas mostrando um corte transversal onde podem ser vistos os microesporófilos $(\mathrm{mi})$ ao redor do eixo $(e)$, dispostos em filotaxia helicoidal e com formato peltado, as brácteas $(b)$ envolven totalmente o cone.

D. Imagem de tomografia computadorizada do espécime Mb.Pb. 2004/0401. Microestróbilo de Araucariostrobus signatus Huertas mostrando um corte longitudinal radial onde pode ser visto o eixo central $(e)$ e os microesporófilos (mi) com formato peltado.

E. Espécime Lp VL 0038. Complexo bráctea-escama do gênero Carpolithes preservado tridimensionalmente e visto desde a parte externa, podem ser observadas as asas laterais $(\mathrm{al})$ e o relevo correspondente à semente $(s)$.

F. Espécime 655. Complexo bráctea-escama do gênero Carpolithes preservado tridimensionalmente e visto desde a parte externa. Pode ser observada a a semente $(s)$ envolvida nos tecidos do complexo, não há preservação de asas ou da parte apical do complexo.

G. Espécime 584. Complexo bráctea-escama do gênero Carpolithes preservado tridimensionalmente e visto em corte longitudinal, com a semente $(s)$ bem preservada no centro do complexo e o restante apenas desenhado na matriz da rocha. 

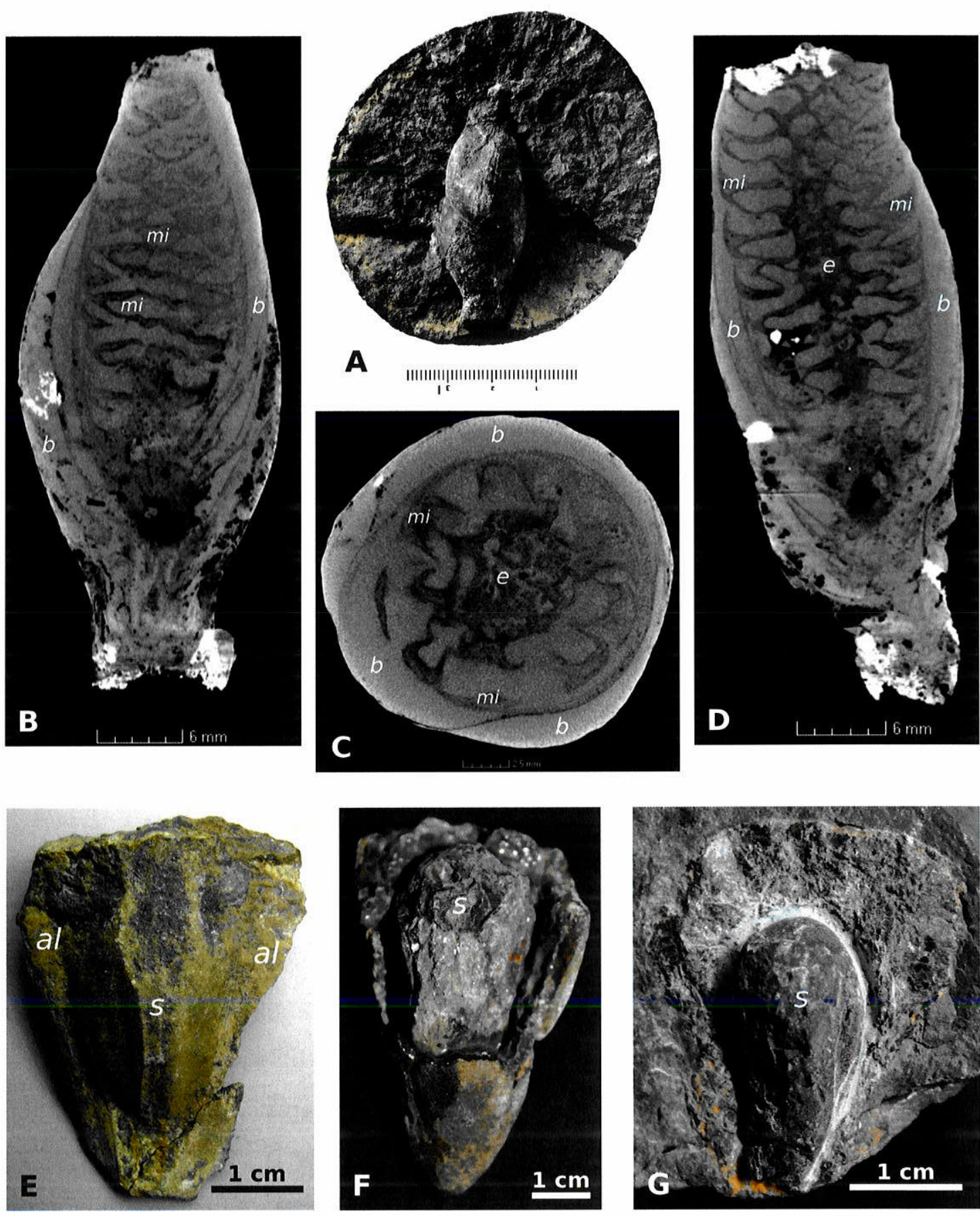

PRANCHA 13 


\section{ANEXOS}

ANEXO 1. Lista de espécies das paleofloras eocretáceas sulamericanas mais diversificadas (excluindo lenhos), agrupadas segundo principais grupos vegetais (ordem ou divisão).

ANEXO 2. Catálogo de espécimes observados.

ANEXO 3. Carta de submissão para a revista Review of Palaeobotany and Palynology e manuscrito intitulado: PHYTOGEOGRAPHIC, STRATIGRAPHIC AND PALEOCLIMATIC SIGNIFICANCE OF PSEUDOFRENELOPSIS CAPILLATA SP. NOV. FROM THE LOWER CRETACEOUS CRATO FORMATION, BRAZIL.

ANEXO 4. Carta de submissão para a revista Cretaceous Research e manuscrito intitulado: ARAUCARIAN BRACT-SCALE COMPLEXES FROM THE CRATO FORMATION, LOWER CRETACEOUS OF ARARIPE BASIN, BRAZIL.

ANEXO 5. Prova de diagramação para o manuscrito: INDICADORES PALEOCLIMÁTICOS NA PALEOFLORA DO CRATO, FINAL DO APTIANO DO GONDWANA NOROCIDENTAL que será publicado no livro: Paleoclimas - Série Paleontologia: Cenários de Vida, editora Interciência. 
ANEXO 1 


\section{ANEXO 1}

Lista de espécies das paleofloras eocretáceas sulamericanas mais diversificadas (excluindo lenhos), agrupadas segundo principais grupos vegetais (ordem ou divisão).

\begin{tabular}{|c|c|c|c|c|c|c|c|c|}
\hline & A & C & D & $\mathbf{E}$ & F & G & H & I \\
\hline \multicolumn{9}{|l|}{ ESFENÓFITAS } \\
\hline Equisetites decipiens & & $\mathrm{x}$ & $\mathrm{X}$ & & & & & \\
\hline Equisetites pusillus & & & & & & $\mathrm{x}$ & & \\
\hline Equisetites sp. & & & & $\mathrm{X}$ & & $\mathrm{x}$ & & \\
\hline Equisetum lyelli & & & & $\mathrm{X}$ & & & & \\
\hline Sphenophyllum columbianum & & $\mathrm{x}$ & & & & & & \\
\hline \multicolumn{9}{|l|}{ PTERIDÓFITAS } \\
\hline Adiantopteris tripinnata & & & & & & $\mathrm{X}$ & & \\
\hline Baqueroites padulae & & & & & & $\mathrm{x}$ & & \\
\hline Cladophlebis antarctica & & & & & & $\mathrm{x}$ & $\mathrm{x}$ & \\
\hline Cladophlebis australis & & & & & & & $\mathrm{x}$ & \\
\hline Cladophlebis browniana & & & $\mathrm{X}$ & & & & $\mathrm{x}$ & \\
\hline Cladophlebis cyathifolia & & & & & & $\mathrm{x}$ & & \\
\hline Cladophlebis denticulata & $\mathrm{x}$ & & & & & & & \\
\hline Cladophlebis exiliformis & $\mathrm{x}$ & & & & & & & \\
\hline Cladophlebis harburnensis & & & & & & $\mathrm{x}$ & & \\
\hline Cladophlebis koraiensis & $\mathrm{x}$ & & & & & & & \\
\hline Cladophlebis kurtzii & & & & & & & $\mathrm{x}$ & \\
\hline Cladophlebis patagonica & & & & & & $\mathrm{x}$ & $\mathrm{x}$ & \\
\hline Cladophlebis tripinnata & & & & & & $\mathrm{x}$ & & \\
\hline Cladophlebis sp. & & & $\mathrm{x}$ & $\mathrm{x}$ & & $\mathrm{x}$ & & $\mathrm{x}$ \\
\hline Coniopteris baldonii & & & & & & & $\mathrm{x}$ & \\
\hline Coniopteris martinezii & & & $\mathrm{X}$ & & & & & \\
\hline Cyathea cyathifolia & & & & & & $\mathrm{x}$ & & \\
\hline Filicites ellensis & & & & $\mathrm{x}$ & & & & \\
\hline Gleichenites argentinica & & & & & & $\mathrm{x}$ & & \\
\hline Gleichenites cf. G. argentinica & & & & & & $\mathrm{X}$ & & \\
\hline Gleichenites ferruglioi & & & & & & $\mathrm{X}$ & & \\
\hline Gleichenites micromerus & & & & & & & $\mathrm{x}$ & \\
\hline Gleichenites medinensis & & & & & & & $\mathrm{x}$ & \\
\hline Gleichenites porsildi & $\mathrm{x}$ & & & & & & & \\
\hline Gleichenites sanmartini & $\mathrm{x}$ & & & & & $\mathrm{X}$ & $\mathrm{X}$ & \\
\hline Gleichenites vegagrandis & & & & & & $\mathrm{X}$ & & \\
\hline Hausmania papilio & & & & & & $\mathrm{X}$ & $\mathrm{x}$ & \\
\hline Hausmania patagonica & & & & & & $\mathrm{X}$ & & \\
\hline Klukia zeilleri & & & $\mathrm{X}$ & $\mathrm{X}$ & & & & \\
\hline Paradoxopteris stromeri & & $\mathrm{x}$ & & & & & & \\
\hline Ruffordia goepperti & $\mathrm{X}$ & & $\mathrm{X}$ & $\mathrm{X}$ & $\mathrm{X}$ & & & \\
\hline
\end{tabular}




\begin{tabular}{|c|c|c|c|c|c|c|c|c|}
\hline & A & C & E & $\mathbf{F}$ & G & H & I & $\mathbf{J}$ \\
\hline \multicolumn{9}{|l|}{ PTERIDÓFITAS } \\
\hline Ruffordia cf. R. goepperti & & & $\mathrm{X}$ & $\mathrm{X}$ & & $\mathrm{X}$ & & \multirow{6}{*}{$\mathrm{X}$} \\
\hline Tempskya multitabularis & & $\mathrm{X}$ & & & & & & \\
\hline Thinfeldia sp. & & & $\mathrm{X}$ & & & & & \\
\hline Todites williamsoni & & & & & & & & \\
\hline Weichselia peruviana & & $\mathrm{X}$ & & $\mathrm{X}$ & & & & \\
\hline Weichselia reticulata & & & $\mathrm{X}$ & & & & & \\
\hline \multicolumn{9}{|c|}{ FOLHAGEM DE AFINIDADE INCERTA } \\
\hline Asplenites lanceolatus & & & & & & & $\mathrm{X}$ & \\
\hline Sphenopteris baqueroensis & & & & & & $\mathrm{X}$ & & \\
\hline Sphenopteris berthoni & & & & $\mathrm{X}$ & & & & \\
\hline Sphenopteris cf. S. fittoni & & & & & & $\mathrm{X}$ & & \\
\hline Sphenopteris goepperti & & & & & & $\mathrm{X}$ & $\mathrm{x}$ & \\
\hline Sphenopteris cf. S. naktongensis & & & & & & & $\mathrm{x}$ & \\
\hline Sphenopteris cf. S. nordenskjoldi & & & & & & $\mathrm{X}$ & $\mathrm{x}$ & \\
\hline Sphenopteris patagonica & & & & & & $\mathrm{X}$ & $\mathrm{x}$ & \\
\hline Sphenopteris psilotoides & & & & & & $\mathrm{x}$ & $\mathrm{x}$ & \\
\hline Sphenopteris sueroi & & & & & & $\mathrm{X}$ & & \\
\hline Sphenopteris thoriana & & & & & & $\mathrm{x}$ & & \\
\hline Sphenopteris sp. & $\mathrm{X}$ & & & & & $\mathrm{X}$ & & \\
\hline \multicolumn{9}{|l|}{ Taeniopteris dissecta } \\
\hline Taeniopteris magninervatus & & $\mathrm{X}$ & & & & & & \\
\hline Taeniopteris sp. & & $\mathrm{X}$ & & $\mathrm{X}$ & & $\mathrm{X}$ & $\mathrm{X}$ & \\
\hline Spiropteris sp. & & & & & & $\mathrm{X}$ & & \\
\hline \multicolumn{9}{|l|}{ Incertae sedis } \\
\hline Novaolindia dubia & & & & & $\mathrm{X}$ & & & \\
\hline \multicolumn{9}{|l|}{ PTERIDOSPERMALES } \\
\hline Antholithus sp. & & & & $\mathrm{X}$ & & & & \\
\hline Ktalenia circularis & & & & & & $\mathrm{X}$ & & \\
\hline Mesosingeria coriacea & & & & & & $\mathrm{X}$ & & \\
\hline Mesosingeria herbstii & & & & & & $\mathrm{X}$ & & \\
\hline Mesosingeria mucronata & & & & & & $\mathrm{x}$ & & \\
\hline Mesosingeria obtusa & & & & & & $\mathrm{X}$ & & \\
\hline Mesosingeria parva & & & & & & $\mathrm{x}$ & & \\
\hline Mesosingeria striata & & & & & & $\mathrm{X}$ & & \\
\hline Onychiopsis sp. & & & $\mathrm{X}$ & & & & & \\
\hline Pachypteris elegans & & & & & & $\mathrm{X}$ & & \\
\hline Pachypteris sp. & $\mathrm{X}$ & & & & & & & \\
\hline Ruflorinia papillosa & & & & & & $\mathrm{X}$ & & \\
\hline Ruflorinia pilifera & & & & & & $\mathrm{X}$ & & \\
\hline Ruflorinia sierra & & & & & & $\mathrm{X}$ & & \\
\hline Ruflorinia sp. & & & & & & $\mathrm{X}$ & & \\
\hline Sagenopteris cf. S. paucifolia & & & $\mathrm{X}$ & & & & & \\
\hline Sagenopteris sp. & $\mathrm{X}$ & & & & & & & \\
\hline
\end{tabular}




\begin{tabular}{|c|c|c|c|c|c|c|c|c|}
\hline & A & C & E & F & G & H & I & J \\
\hline \multicolumn{9}{|l|}{ CYCADALES } \\
\hline Almargemia incrassata & & & & & & $\mathrm{X}$ & & \\
\hline Androstrobus munku & & & & & & $\mathrm{X}$ & & \\
\hline Androstrobus patagonicus & & & & & & $\mathrm{x}$ & & \\
\hline Androstrobus rayen & & & & & & $\mathrm{x}$ & & \\
\hline Ctenozamites sp. & $\mathrm{x}$ & & & & & & & \\
\hline Cycadoidea perpusilla & & $\mathrm{X}$ & & & & & & \\
\hline Macrotaeniopteris sp. & & $\mathrm{X}$ & & & & & & \\
\hline Mesodescolea plicata & & & & & & $\mathrm{X}$ & & \\
\hline Nilssonia clarkii & & & & & & $\mathrm{x}$ & & \\
\hline Nilssonia cf. $N$ orientalis & & $\mathrm{X}$ & & & & & & \\
\hline Nilssonia cf. N. princeps & & $\mathrm{x}$ & & & & & & \\
\hline Nilssonia sp. & & & & & & $\mathrm{x}$ & & \\
\hline Pseudoctenis crassa & & & & & & $\mathrm{x}$ & & \\
\hline Pseudoctenis dentata & & & & & & $\mathrm{x}$ & & \\
\hline Pseudoctenis giganteus & & & & & & $\mathrm{x}$ & & \\
\hline Pseudoctenis ensiformis & & & & & & & $\mathrm{X}$ & \\
\hline Pseudoctenis ornata & & & & & & $\mathrm{x}$ & & \\
\hline Pseudoctenis sp. & & & & & & $\mathrm{x}$ & $\mathrm{X}$ & \\
\hline Restrepophyllum chiguoides & & & & & & $\mathrm{x}$ & & \\
\hline Sueria elegans & & & & & & $\mathrm{x}$ & & \\
\hline Sueria rectinervis & & & & & & $\mathrm{x}$ & & \\
\hline Ticoa harrisi & & & & & & $\mathrm{x}$ & & \\
\hline Ticoa lamellata & & & & & & $\mathrm{x}$ & & \\
\hline Ticoa lanceolata & & & & & & $\mathrm{x}$ & & \\
\hline Ticoa magallanica & & & & & & & & $\mathrm{X}$ \\
\hline Ticoa magnipinnulata & & & & & & $\mathrm{x}$ & & \\
\hline Zamiostrobus crassus & & & & $\mathrm{x}$ & & & & \\
\hline \multicolumn{9}{|l|}{ BENNETTITALES } \\
\hline Anomozamites minor & $\mathrm{X}$ & & & & & & & \\
\hline Cycadolepis baqueroensis & & & & & & $\mathrm{x}$ & & \\
\hline Cycadolepis bonnieri & & & $\mathrm{X}$ & $\mathrm{X}$ & & & & \\
\hline Cycadolepis coriacea & & & & & & $\mathrm{x}$ & & \\
\hline Cycadolepis involuta & & & & & & $\mathrm{X}$ & & $\mathrm{x}$ \\
\hline Cycadolepis jenkinsiana & & & & & & $\mathrm{X}$ & & \\
\hline Cycadolepis lanceolata & & & & & & $\mathrm{X}$ & & \\
\hline Cycadolepis menendezii & & & & & & $\mathrm{X}$ & & \\
\hline Cycadolepis oblonga & & & & & & $\mathrm{x}$ & & \\
\hline Cycadolepis petriellae & & & & & & $\mathrm{x}$ & & \\
\hline Cycadolepis sp. & & & & $\mathrm{x}$ & & & & $\mathrm{x}$ \\
\hline Dictyozamites areolatus & & & & & & $\mathrm{X}$ & & \\
\hline Dictyozamites crassinervis & & & & & & $\mathrm{x}$ & & \\
\hline Dictyozamites latifolius & & & & & & $\mathrm{x}$ & & \\
\hline Dictyozamites minusculus & & & & & & $\mathrm{x}$ & & \\
\hline
\end{tabular}




\begin{tabular}{|c|c|c|c|c|c|c|c|c|}
\hline & $\mathbf{A}$ & C & E & F & G & H & I & J \\
\hline \multicolumn{9}{|l|}{ BENNETTITALES } \\
\hline Nilssoniopteris major & $\mathrm{X}$ & & & & & & & \\
\hline Otozamites archangelskyi & & & & & & & & $\mathrm{X}$ \\
\hline Otozamites grandis & & & & & & $\mathrm{X}$ & & \\
\hline Otozamites ornatus & & & & & & $\mathrm{X}$ & & \\
\hline Otozamites parviauriculata & & & & & & $\mathrm{X}$ & & \\
\hline Otozamites parvus & & & & & & & & $\mathrm{X}$ \\
\hline Otozamites patagonicus & & & & & & & & $\mathrm{X}$ \\
\hline Otozamites peruvianus & & & $\mathrm{x}$ & & & & & \\
\hline Otozamites cf. O. peruvianus & $\mathrm{X}$ & & & & & & & \\
\hline Otozamites simotatoi & $\mathrm{X}$ & & & & & & & \\
\hline Otozamites waltoni & & & & & & $\mathrm{x}$ & & \\
\hline Otozamites sp. & $\mathrm{X}$ & & & & & & $\mathrm{X}$ & $\mathrm{X}$ \\
\hline Pterophyllum trichomatosum & & & & & & $\mathrm{x}$ & & \\
\hline Pterophyllum sp. & & & $\mathrm{x}$ & & & & & \\
\hline Ptilophyllum acutifolium & & & & & & & $\mathrm{X}$ & \\
\hline Ptilophyllum angustus & & & & & & & & $\mathrm{X}$ \\
\hline Ptilophyllum antarcticum & & & & & & $\mathrm{x}$ & $\mathrm{x}$ & $\mathrm{x}$ \\
\hline Ptilophyllum cf. P. cutchense & $\mathrm{X}$ & & & & & & & \\
\hline Ptilophyllum cf. P. distans & $\mathrm{X}$ & & & & & & & \\
\hline Ptilophyllum guiense & & & & & & & & $\mathrm{X}$ \\
\hline Ptilophyllum hislopii & & & & & & $\mathrm{X}$ & & \\
\hline Ptilophyllum longipinnatum & & & & & & $\mathrm{X}$ & & \\
\hline Ptilophyllum valvatum & & & & & & & & $\mathrm{x}$ \\
\hline Ptilophyllum sp. & & & & & & $\mathrm{X}$ & $\mathrm{x}$ & $\mathrm{x}$ \\
\hline Willamsonia bulbiformis & & & & & & $\mathrm{X}$ & & \\
\hline Willamsonia umbonata & & & & & & $\mathrm{X}$ & & \\
\hline Williamsoniella boyacana & & $\mathrm{X}$ & & & & & & \\
\hline Zamites decurrens & & & & & & $\mathrm{X}$ & & \\
\hline Zamites gigas & & & & & & & & $\mathrm{x}$ \\
\hline Zamites grandis & & & & & & $\mathrm{X}$ & & \\
\hline Zamites lucerensis & $\mathrm{X}$ & & & & & & & \\
\hline \multicolumn{9}{|l|}{ Zamites cf. quiniae } \\
\hline Zamites sp. & & & & & & & & $\mathrm{x}$ \\
\hline \multicolumn{9}{|l|}{ GINKGOALES } \\
\hline Allicospermum patagonicum & & & & & & $\mathrm{X}$ & & \\
\hline Ginkgoites skottsbergi & & & & & & & $\mathrm{X}$ & \\
\hline Ginkgoites ticoensis & & & & & & $\mathrm{X}$ & & \\
\hline Ginkgoites tigrensis & & & & & & $\mathrm{X}$ & & \\
\hline Karkenia incurva & & & & & & $\mathrm{X}$ & & \\
\hline \multicolumn{9}{|l|}{ CONIFERALES } \\
\hline Alkastrobus pentatus & & & & & & $\mathrm{X}$ & & \\
\hline Apterocladus lanceolatus & & & & & & $\mathrm{X}$ & $\mathrm{x}$ & \\
\hline Araucaria cartellei & & & & & $\mathrm{X}$ & & & \\
\hline
\end{tabular}

Anexo 1-4 


\begin{tabular}{|c|c|c|c|c|c|c|c|c|}
\hline & A & C & E & F & G & H & I & J \\
\hline \multicolumn{9}{|l|}{ CONIFERALES } \\
\hline Araucaria grandifolia & & & & & & $\mathrm{X}$ & & \\
\hline Araucaria sp. & & & & & $\mathrm{x}$ & $\mathrm{X}$ & & \\
\hline Araucariostrobus archangelskii & & $\mathrm{x}$ & & & & & & \\
\hline Araucariostrobus cf. A. archangelskii & & $\mathrm{X}$ & & & & & & \\
\hline Araucariostrobus brievanus & & $\mathrm{x}$ & & & & & & \\
\hline Araucariostrobus camargoi & & $\mathrm{x}$ & & & & & & \\
\hline Araucariostrobus carmenii & & $\mathrm{X}$ & & & & & & \\
\hline Araucariostrobus creutzbergi & & $\mathrm{X}$ & & & & & & \\
\hline Araucariostrobus gracilis & & $\mathrm{x}$ & & & & & & \\
\hline Araucariostrobus protectus & & $\mathrm{X}$ & & & & & & \\
\hline Araucariostrobus signatus & & $\mathrm{X}$ & & & & & & \\
\hline Araucariostrobus sp. & & & & & $\mathrm{x}$ & & & \\
\hline Araucarites baqueroensis & & & & & & $\mathrm{X}$ & & \\
\hline Araucarites chilensis & & & & & & & & $\mathrm{X}$ \\
\hline Araucarites minimus & & & & & & $\mathrm{x}$ & & \\
\hline Araucarites vulcanoi & & & & & $\mathrm{x}$ & & & \\
\hline Araucarites solivagus & & $\mathrm{X}$ & & & & & & \\
\hline Athrotaxis ungeri & & & & & & $\mathrm{X}$ & & \\
\hline Brachyphyllum baqueroense & & & & & & $\mathrm{x}$ & & \\
\hline Brachyphyllum bretii & & & & & & $\mathrm{x}$ & & \\
\hline Brachyphyllum feistmantelii & & & & & & & & $\mathrm{X}$ \\
\hline Brachyphyllum insigne & & & & & $\mathrm{x}$ & & & \\
\hline Brachyphyllum irregulare & & & & & & $\mathrm{x}$ & & \\
\hline Brachyphyllum mirandai & & & & & & $\mathrm{x}$ & & \\
\hline Brachyphyllum mucronatum & & & & & & $\mathrm{x}$ & & \\
\hline Brachyphyllum obesum & & & & & $\mathrm{x}$ & & & \\
\hline Brachyphyllum peruvianum & & & $\mathrm{x}$ & & & & & \\
\hline Brachyphyllum pompeckji & & & & $\mathrm{X}$ & & & & \\
\hline Brachyphyllum tigrense & & & & & & $\mathrm{x}$ & & \\
\hline Brachyphyllum winklerprinsi & & $\mathrm{X}$ & & & & & & \\
\hline Brachyphyllum sp. & & $\mathrm{X}$ & & & & $\mathrm{x}$ & & $\mathrm{X}$ \\
\hline Conites sp. & & $\mathrm{X}$ & & & & & & \\
\hline Cupressinocladus hoedemaekeri & & $\mathrm{X}$ & & & & & & \\
\hline Cupressinocladus leivanum & & $\mathrm{X}$ & & & & & & \\
\hline Cupressinocladus lepidophyllus & & $\mathrm{X}$ & & & & & & \\
\hline Cupressinocladus sutamarchensis & & $\mathrm{X}$ & & & & & & \\
\hline Cupressinocladus sp. & & $\mathrm{X}$ & & & & & & \\
\hline Cyparissidium sp. & & $\mathrm{x}$ & & & & & & \\
\hline Damarites acostae & & $\mathrm{X}$ & & & & & & \\
\hline Damarites carmelitanus & & $\mathrm{X}$ & & & & & & \\
\hline Damarites conicus & & $\mathrm{X}$ & & & & & & \\
\hline Damarites kucii & & $\mathrm{X}$ & & & & & & \\
\hline Damarites yarzenii & & $\mathrm{X}$ & & & & & & \\
\hline
\end{tabular}




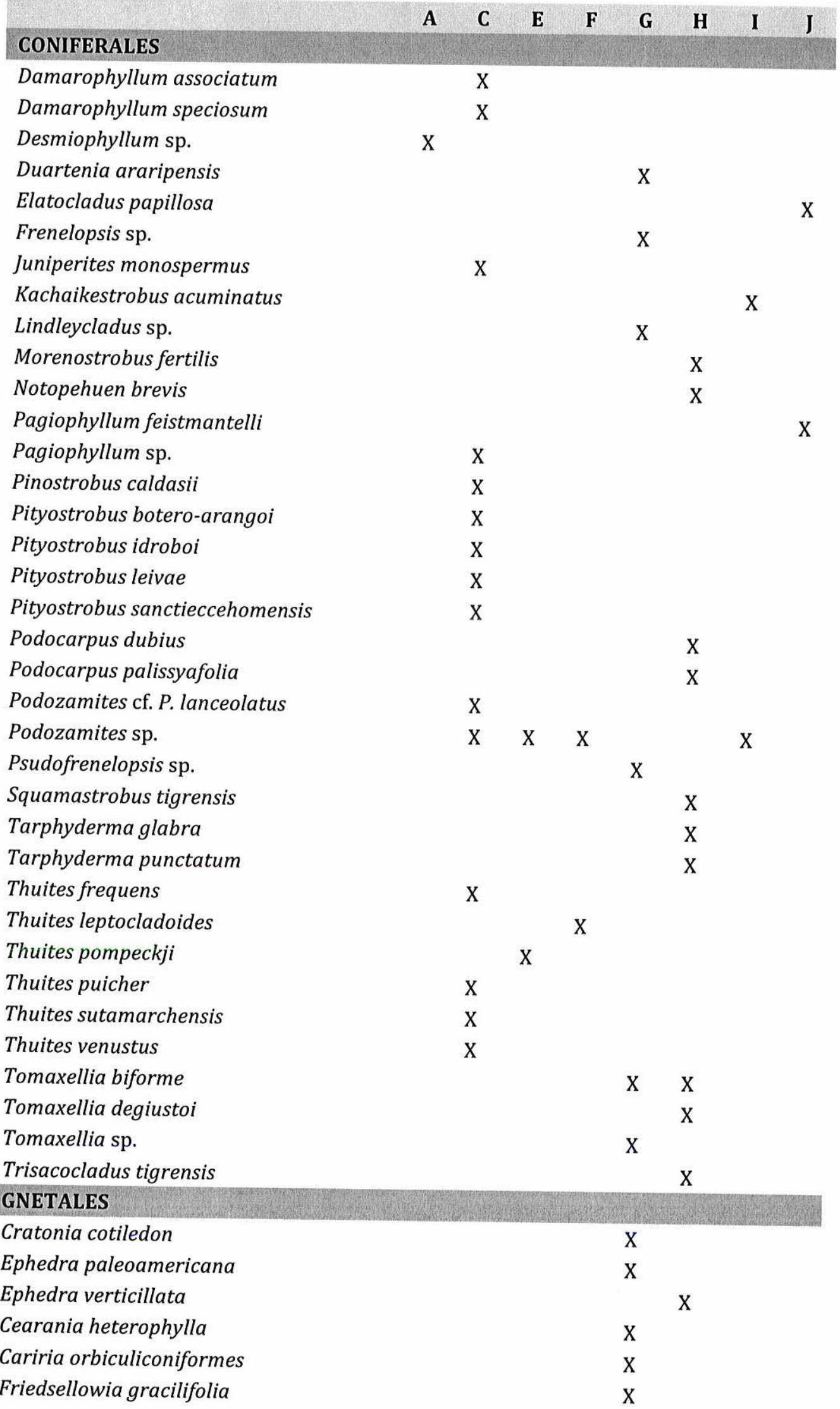




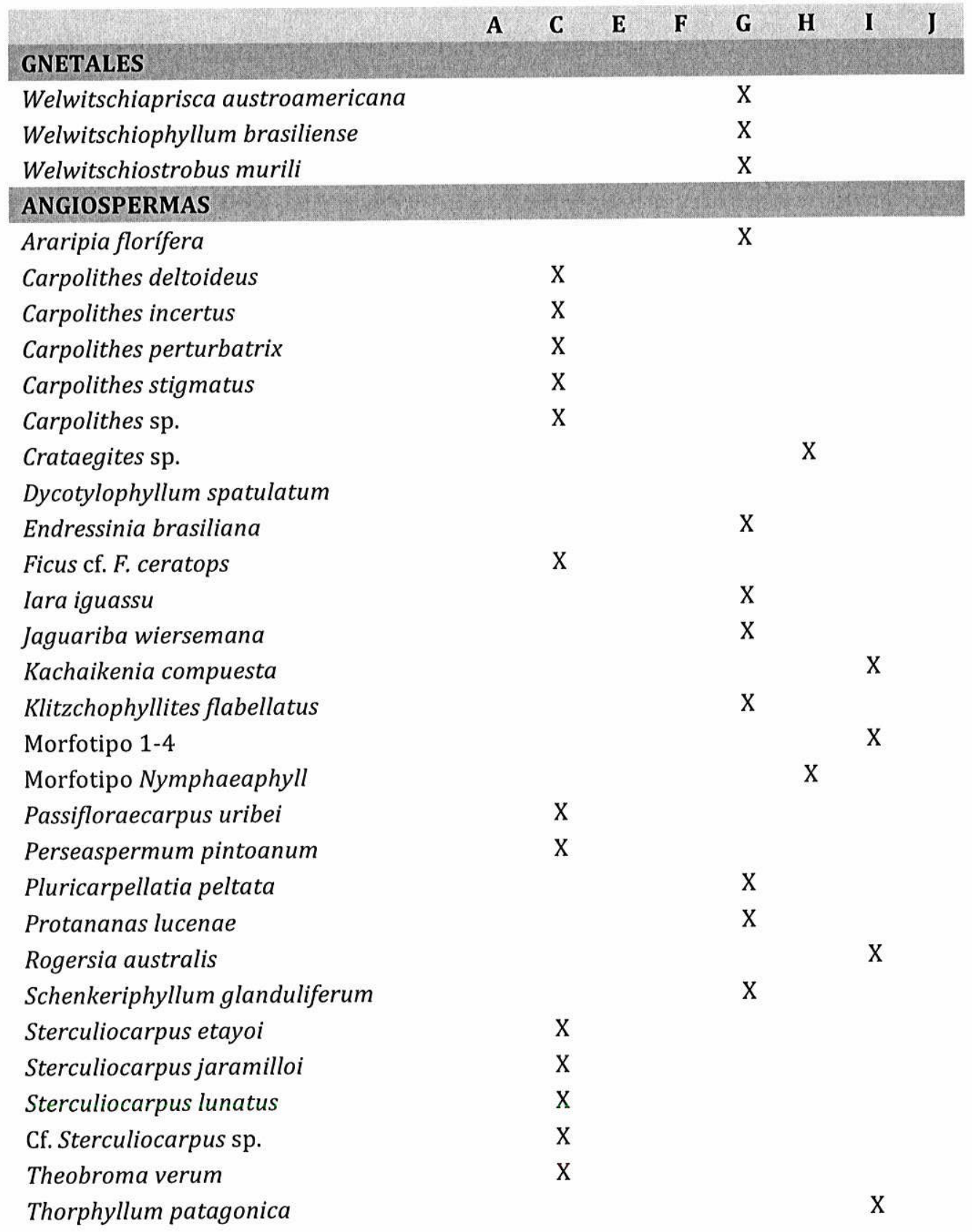

A. Formação Valle Alto, Cordilheira Central, Departamento de Caldas, Colômbia (Lemoigne, 1984).

B. Formação Paja na Região de Villa de Leyva, Cordilheira Oriental, Departamento de Boyacá, Colômbia (Huertas, 1967, 1970, 1971, 1976, 2003; Pons, 1982a, 1982b, 1988; Van Waveren et al. 2002).

C. Ocorrências fitofossilíferas de Huallanca no Departamento de Huanuco, Peru (Berry, 1922, 1939). 
D. Ocorrências fitofossilíferas da Ilha de San Lorenzo em El Callao, Peru (Berry, 1922, 1939).

E. Formação Crato (Duarte, 1985, 1989, 1993; Mohr \& Rydin, 2002; Mohr \& Eklund, 2003; Rydin et al. 2003; Kunzmann et al. 2004, 2006, 2007, 2009, 2011; Mohr \& Bernardes-de-Oliveira, 2004; Dilcher et al. 2005; Bernardes-de-Oliveira et al. 2006; Fanton et al. 2006; Mohr et al. 2006, 2008, 2012, 2013; Kerkhoff \& Dutra 2007; Coiffard et al. 2013; Leme et al. (no prelo); Löwe et al. (no prelo)).

F. Grupo Baqueró, Província de Santa Cruz (Herbst, 1962; Archangelsky, 1963a, 1963b, 1963c, 1964a, 1964b, 1965a, 1965b, 1966, 1967a; Menendez, 1965, 1966; Traverso, 1966; Archangelsky \& Baldoni, 1972a, 1972b; Baldoni, 1974; Archangelsky \& Taylor, 1986; Archangelsky \& del Fueyo, 1989; Del Fueyo et al. 1990, 2007, 2009; Archangelsky et al. 1995; Villar de Seoane, 1996, 1997, 1999, 2005; Del Fueyo \& Archangelsky, 2002; Archangelsky \& Villar de Seoane, 2004; Limarino et al. 2012).

G. Formação Kachaike, Provincia de Santa Cruz (Halle, 1913; Archangelsky, 1967b; Baldoni, 1980b, 1981; Baldoni \& Ramos, 1981; Longobuco et al. 1985; Cuneo \& Gandolfo, 2005; Del Fueyo et al. 2007, 2008).

H. Formação Springhill, Província de Santa Cruz (Archangelsky, 1979; Baldoni, 1979; Cortiñas \& Arbe, 1981; Baldoni \& Taylor, 1983; Villar de Seoane, 1995, 2001; Del Fueyo et al. 2007). 


\section{ANEXO 2}

Catálogo de espécimes

Os espécimes analisados nesta tese, encontram-se a seguir catalogados segundo a instituição depositária (Itens A-K), com o tipo de órgão que representam e observações como seu código de identificação (quando existente). A escala nas tabelas está em centímetros e as barras medem um centímetro. Espécimes marcados com * se encontram em empréstimo pela instituição depositária ao IGc/USP.

A. Espécimes examinados da coleção científica do Laboratório de Paleontologia Sistemática do Instituto de Geociências da Universidade de São Paulo

\begin{tabular}{|c|c|c|c|c|c|}
\hline Tipo de órgão & Ramo folhoso & Ramo folhoso & Ramo folhoso & Ramo folhoso & Cone \\
\hline Procedência & Formação Crato & Formação Crato & Formação Crato & Formação Crato & Formação Crato \\
\hline & & & & \\
& & &
\end{tabular}




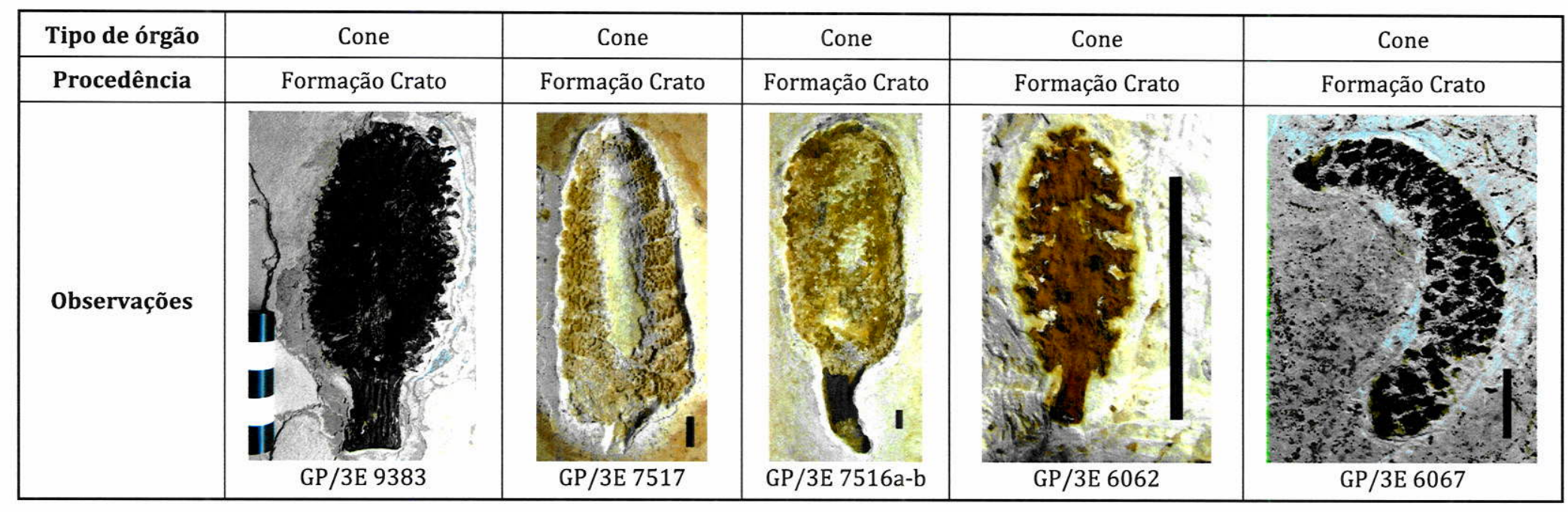

\begin{tabular}{|c|c|c|c|c|c|}
\hline $\begin{array}{l}\text { Tipo de } \\
\text { órgão }\end{array}$ & Cone & $\begin{array}{l}\text { Complexo bráctea- } \\
\text { escama }\end{array}$ & $\begin{array}{l}\text { Complexo bráctea- } \\
\text { escama }\end{array}$ & $\begin{array}{l}\text { Complexo bráctea- } \\
\text { escama }\end{array}$ & $\begin{array}{l}\text { Complexo bráctea- } \\
\text { escama }\end{array}$ \\
\hline Procedência & Formação Romualdo & Formação Crato & Formação Crato & Formação Crato & Formação Crato \\
\hline Observações & $\frac{\text { GP/3E } 7513}{\mathrm{GP}}$ & GP/3E 9109 & GP/3E $9110 a-b$ & GP/3E 9114 & 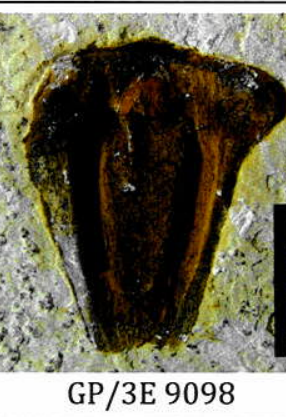 \\
\hline
\end{tabular}




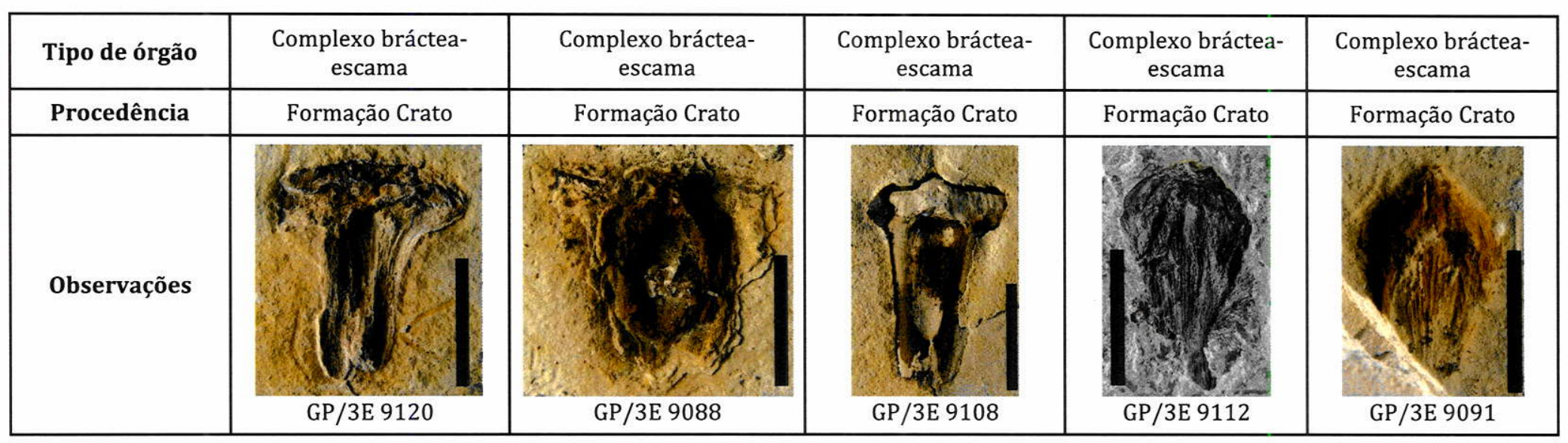

\begin{tabular}{|c|c|c|c|}
\hline $\begin{array}{c}\text { Tipo de } \\
\text { órgão }\end{array}$ & Complexo bráctea-escama & $\begin{array}{c}\text { Complexo bráctea- } \\
\text { escama }\end{array}$ & $\begin{array}{c}\text { Complexo bráctea- } \\
\text { escama }\end{array}$ \\
\hline Procedência & Formação Crato & Formação Crato & Formação Crato \\
\hline & & & \\
Observações & & & \\
& & & \\
\hline
\end{tabular}


B. Espécimes examinados da coleção do Museu Paleontológico de Santana do Cariri da Universidade Regional do Cariri, Santana do Cariri-CE.

\begin{tabular}{|c|c|c|c|c|c|}
\hline Tipo de órgão & Ramo folhoso & Ramo folhoso & Cone & Cone & $\begin{array}{c}\text { Complexo bráctea- } \\
\text { escama }\end{array}$ \\
\hline Procedência & Formação Crato & Formação Crato & Formação Crato & Formação Crato & Formação Crato \\
\hline Observações & MPSC PL 560* & MPSC PL 577* & MPSC PL $1035^{*}$ & 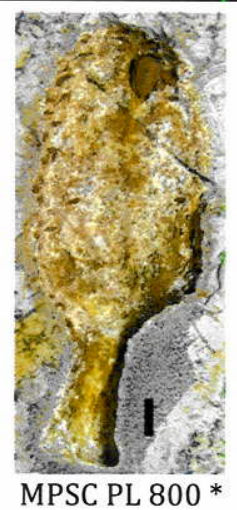 & MPSC PL 651* \\
\hline
\end{tabular}

\begin{tabular}{|c|c|c|c|c|c|}
\hline Tipo de órgão & Cone & Cone & Cone & Cone & Cone \\
\hline Procedência & Formação Crato & Formação Crato & Formação Crato & Formação Crato & Formação Crato \\
\hline \multicolumn{6}{|l|}{ Observações } \\
\hline & MPSC PL 809* & MPSC PL 2105* & & & \\
\hline
\end{tabular}




\begin{tabular}{|c|c|c|c|c|}
\hline Tipo de órgão & Cone & Cone & Ramo folhoso & Ramo folhoso \\
\hline Procedência & Formação Crato & Formação Crato & Formação Romualdo & Formação Romualdo \\
\hline \multicolumn{5}{|l|}{ Observações } \\
\hline & & MPSC $655^{*}$ & sem número * & MPSC $1264^{*}$ \\
\hline
\end{tabular}

C. Espécimes examinados da coleção do Laboratório de Paleontologia da Universidade Regional do Cariri, Crato-CE.

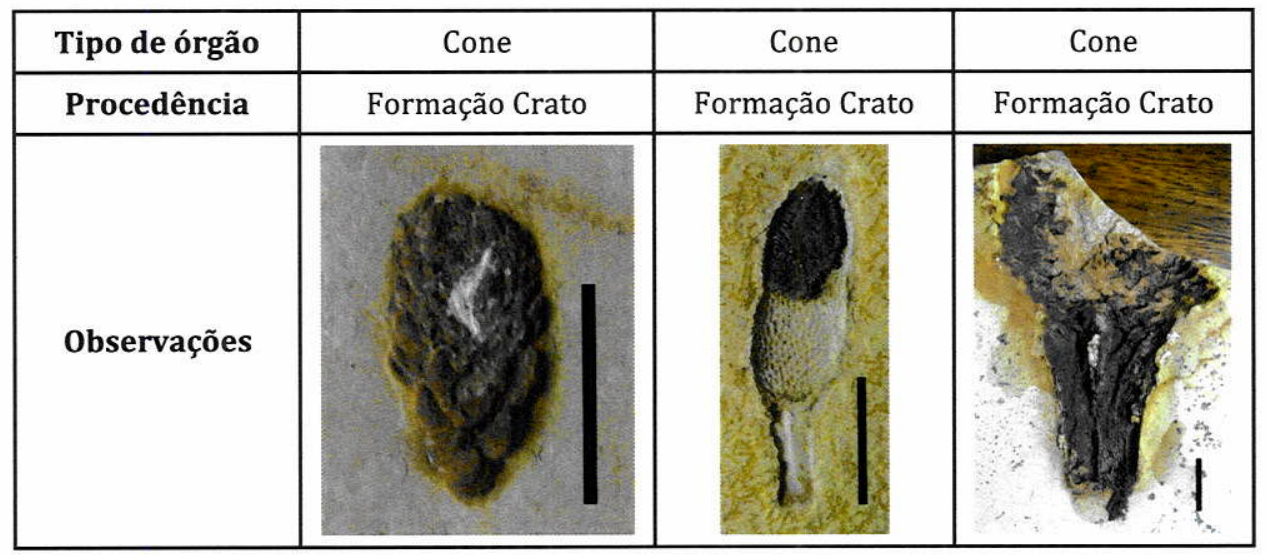


D. Espécimes examinados da coleção do Museu dos Fósseis do DNPM, Crato-CE.

\begin{tabular}{|c|c|c|c|c|}
\hline Tipo de órgão & Cone & Cone & Cone & Cone \\
\hline Procedência & Formação Crato & Formação Crato & Formação Crato & Formação Crato \\
\hline \multicolumn{5}{|l|}{ Observações } \\
\hline & $\overline{\text { CPCA } 8}$ & 3620 & & $3619^{*}$ \\
\hline
\end{tabular}

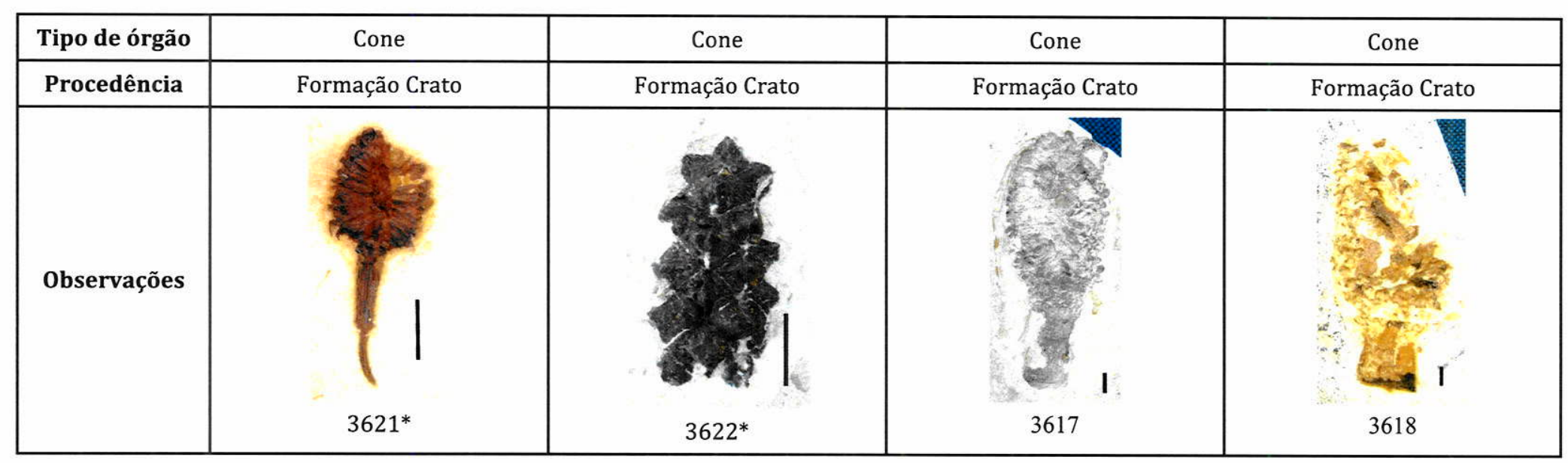


E. Espécimes examinados da coleção do Museu Nacional de Rio de Janeiro, UFRJ.

\begin{tabular}{|c|c|c|c|c|}
\hline Tipo de órgão & $\begin{array}{c}\text { Complexo bráctea- } \\
\text { escama }\end{array}$ & $\begin{array}{c}\text { Complexo bráctea- } \\
\text { escama }\end{array}$ & $\begin{array}{c}\text { Complexo bráctea- } \\
\text { escama }\end{array}$ & $\begin{array}{c}\text { Complexo bráctea- } \\
\text { escama }\end{array}$ \\
\hline Procedência & Formação Crato & Formação Crato & Formação Crato & Formação Crato \\
\hline \multirow[t]{2}{*}{ Observações } & & & & \\
\hline & MN 3275 Pb * & $\mathrm{MN} 005 \mathrm{~Pb} *$ & $\mathrm{MN} 008 \mathrm{~Pb} *$ & $\mathrm{MN} 009 \mathrm{~Pb}^{*}$ \\
\hline
\end{tabular}

F. Espécimes examinados da coleção do Instituto de Geociências da Universidade Federal do Rio de Janeiro.

\begin{tabular}{|c|c|c|c|c|c|}
\hline Tipo de órgão & Ramo folhoso & Ramo folhoso & Cone & Cone & Cone \\
\hline Procedência & Formação Crato & Formação Crato & Formação Crato & Formação Crato & Formação Crato \\
\hline \multicolumn{6}{|l|}{ Observações } \\
\hline & $428 \mathrm{~Pb}$ a-b * & $858 \mathrm{~Pb} a-b *$ & $1041 \mathrm{~Pb}$ & UFRJ $1186 \mathrm{~Pb}$ & UFRJ $3286 \mathrm{~Pb}$ \\
\hline
\end{tabular}




\begin{tabular}{|c|c|c|c|c|}
\hline Tipo de órgão & Cone & Cone & Cone & Cone \\
\hline Procedência & Formação Crato & Formação Crato & Formação Crato & Formação Crato \\
\hline \multicolumn{5}{|l|}{ Observações } \\
\hline & UFRJ $1129 \mathrm{~Pb}$ & UFRJ $1182 \mathrm{~Pb}$ & UFRJ $348 \mathrm{~Pb}$ & \\
\hline
\end{tabular}

\begin{tabular}{|c|c|c|c|c|c|}
\hline Tipo de órgão & $\begin{array}{c}\text { Complexo bráctea- } \\
\text { escama }\end{array}$ & $\begin{array}{c}\text { Complexo } \\
\text { bráctea-escama }\end{array}$ & $\begin{array}{c}\text { Complexo } \\
\text { bráctea-escama }\end{array}$ & $\begin{array}{c}\text { Complexo bráctea- } \\
\text { escama }\end{array}$ & $\begin{array}{c}\text { Complexo } \\
\text { bráctea-escama }\end{array}$ \\
\hline Procedência & Formação Crato & Formação Crato & Formação Crato & Formação Crato & Formação Crato \\
\hline \multicolumn{6}{|l|}{ Observações } \\
\hline & UFRJ $379 \mathrm{~Pb}$ * & UFRJ $652 \mathrm{~Pb}$ * & UFRJ $401 \mathrm{~Pb}$ * & UFRJ $856 \mathrm{~Pb} *$ & UFRJ $375 \mathrm{~Pb}$ * \\
\hline
\end{tabular}


G. Espécimes examinados da coleção do Museum für Naturkunde der Humboldt-Universität, Berlim.

\begin{tabular}{|c|c|c|c|c|c|}
\hline Tipo de órgão & Ramo folhoso & Ramo folhoso & Ramo folhoso & Ramo folhoso & Ramo folhoso \\
\hline Procedência & Formação Crato & Formação Crato & Formação Crato & Formação Crato & Formação Crato \\
\hline \multicolumn{6}{|l|}{ Observações } \\
\hline & Mb.Pb. 1999/451 & Mb.Pb. 1999/475 & Mb.Pb. 1999/468 & Mb.Pb. 1999/537 & Mb.Pb. 2002/1344 \\
\hline
\end{tabular}

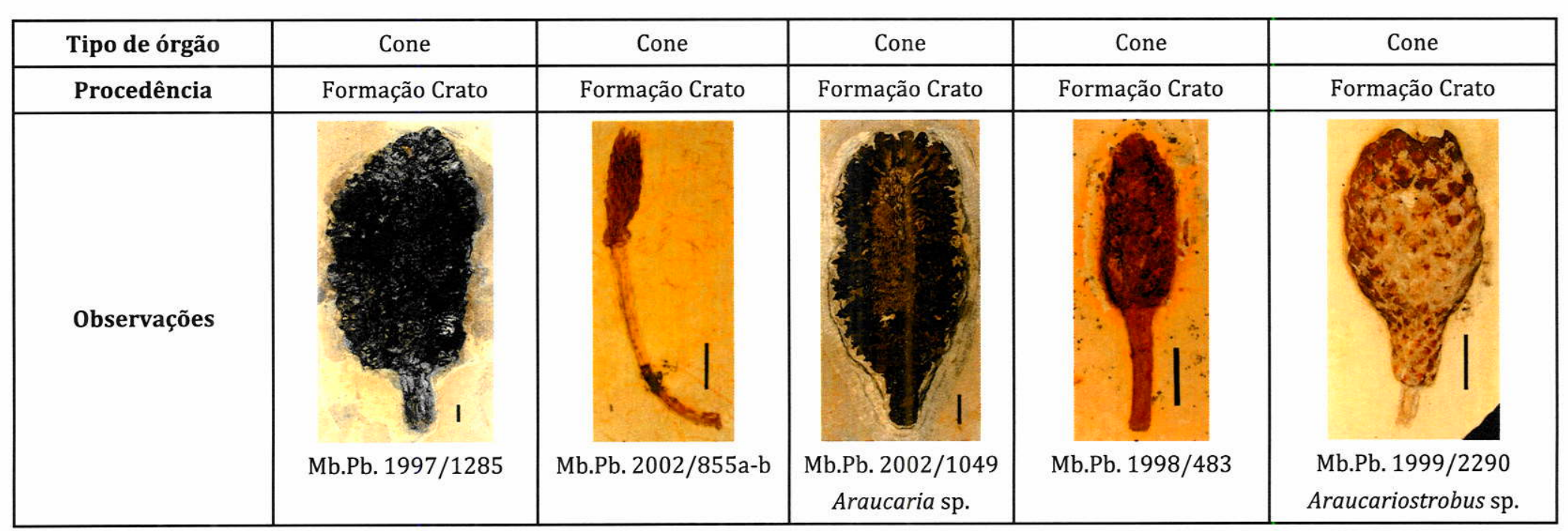




\begin{tabular}{|c|c|c|c|c|c|}
\hline Tipo de órgão & Cone & Cone & Cone & Cone & Cone \\
\hline Procedência & Formação Crato & Formação Crato & Formação Crato & Formação Crato & Formação Crato \\
\hline \multicolumn{6}{|l|}{ Observações } \\
\hline & Mb.Pb. 1999/430 & Mb.Pb. 1999/2297a-b & Mb.Pb. 2002/1340 & Mb.Pb. 1997/1275 & Mb.Pb. 1997/1277 \\
\hline
\end{tabular}

\begin{tabular}{|c|c|c|c|c|c|}
\hline Tipo de órgão & Cone & Cone & Cone & Cone & Cone \\
\hline Procedência & Formação Crato & $\begin{array}{c}\text { Formação } \\
\text { Crato }\end{array}$ & Formação Crato & Formação Crato & Formação Crato \\
\hline \multicolumn{6}{|l|}{ Observações } \\
\hline & Mb.Pb. 1999/439 & $\begin{array}{c}\text { Mb.Pb. } \\
\text { 2001/1398a-b }\end{array}$ & Mb.Pb. 1999/289 & Mb.Pb. 2001/1397 & Mb.Pb. 1997/1246 \\
\hline
\end{tabular}




\begin{tabular}{|c|c|c|c|c|}
\hline Tipo de órgão & Cone & $\begin{array}{c}\text { Complexo bráctea- } \\
\text { escama }\end{array}$ & $\begin{array}{c}\text { Complexo bráctea- } \\
\text { escama }\end{array}$ & Cone \\
\hline Procedência & Formação Crato & Formação Crato & Formação Crato & Formação Paja \\
\hline & Observações & Mb.Pb. 1999/440 & & \\
& Mb.Pb.1996/1373 & $\begin{array}{c}\text { Mb.Pb. 1999/428 } \\
\text { Araucaria sp. }\end{array}$ & Mb.Pb. 2004/0401 \\
\hline
\end{tabular}

H. Espécimes examinados da coleção do Senckenberg Forschungsinstitut und Naturmuseum, Frankfurt.

\begin{tabular}{|c|c|c|c|c|c|}
\hline Tipo de órgão & Ramo folhoso & Ramo folhoso & Ramo folhoso & Ramo folhoso & Ramo folhoso \\
\hline Procedência & Formação Crato & Formação Crato & Formação Crato & Formação Crato & Formação Crato \\
\hline & & & & \\
& Observações & & & &
\end{tabular}




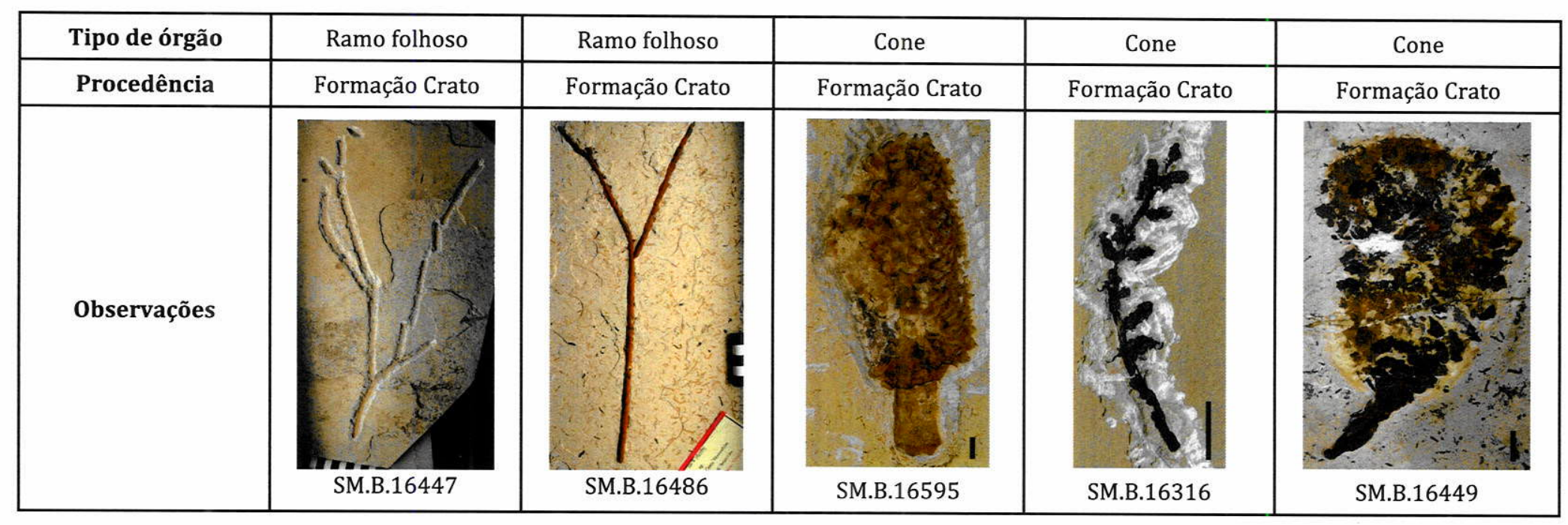

\begin{tabular}{|c|c|c|c|c|}
\hline Tipo de órgão & Cone & Cone & Cone & Cone \\
\hline Procedência & Formação Crato & Formação Crato & Formação Crato & Formação Crato \\
\hline \multicolumn{5}{|l|}{ Observações } \\
\hline & SM.B.16605 & SM.B.16442 & SM.B.16374 & SM.B.16604 \\
\hline
\end{tabular}

Anexo 2-12 


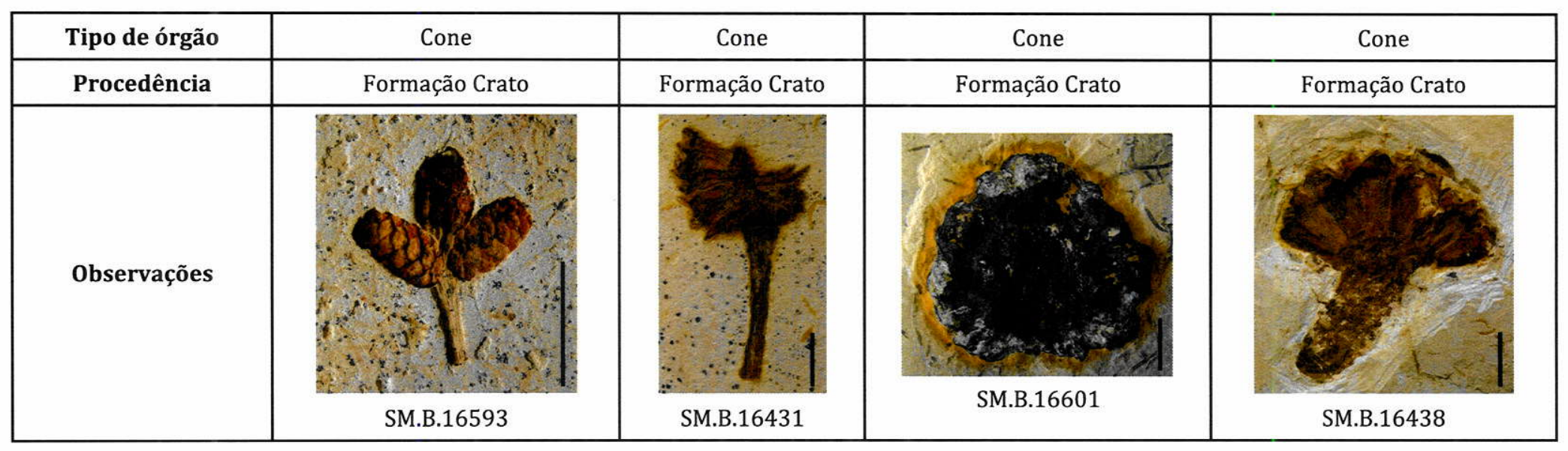

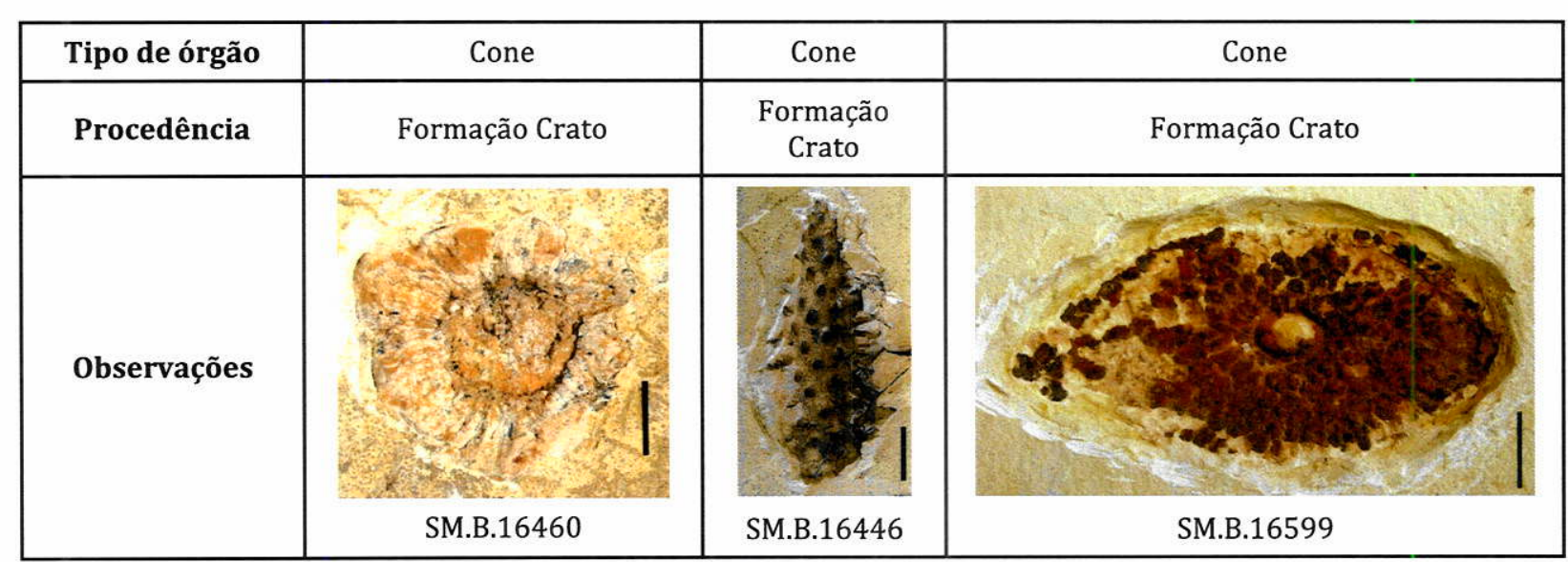




\begin{tabular}{|c|c|c|c|c|}
\hline Tipo de órgão & Complexo bráctea-escama & $\begin{array}{l}\text { Complexo bráctea- } \\
\text { escama }\end{array}$ & Complexo bráctea-escama & Complexo bráctea-escama \\
\hline Procedência & Formação Crato & Formação Crato & Formação Crato & Formação Crato \\
\hline \multirow[t]{2}{*}{ Observações } & & & & \\
\hline & SM.B.16453 & SM.B.16430 & SM.B.16448 & SM.B.16451a-b \\
\hline
\end{tabular}

I. Espécimes examinados no Senckenberg Naturhistorische Sammlungen, Dresden (estes espécimes pertencem a colecionistas particulares e são emprestados temporariamente à instituição para pesquisa).

\begin{tabular}{|c|c|c|c|c|c|c|}
\hline Tipo de órgão & Ramo folhoso & Ramo folhoso & Ramo folhoso & Ramo folhoso & Ramo folhoso & Cone \\
\hline Procedência & Formação Crato & Formação Crato & Formação Crato & Formação Crato & Formação Crato & Formação Crato \\
\hline Observações & & & & & &
\end{tabular}


J. Espécimes examinados da coleção do Laboratorio de Paleontologia de la Universidad de Caldas, Manizales, Colômbia.

\begin{tabular}{|c|c|c|c|c|c|}
\hline Tipo de órgão & Ramo folhoso & Ramo folhoso & Ramo folhoso & Ramo folhoso & Ramo folhoso \\
\hline Procedência & Formação Paja & Formação Paja & Formação Paja & Formação Paja & Formação Paja \\
\hline \multicolumn{6}{|l|}{ Observações } \\
\hline & Lp VL $0002 *$ & Lp VL $0001^{*}$ & Lp VL $0016 *$ & Lp VL $0005^{*}$ & Lp VL $0009 *$ \\
\hline
\end{tabular}

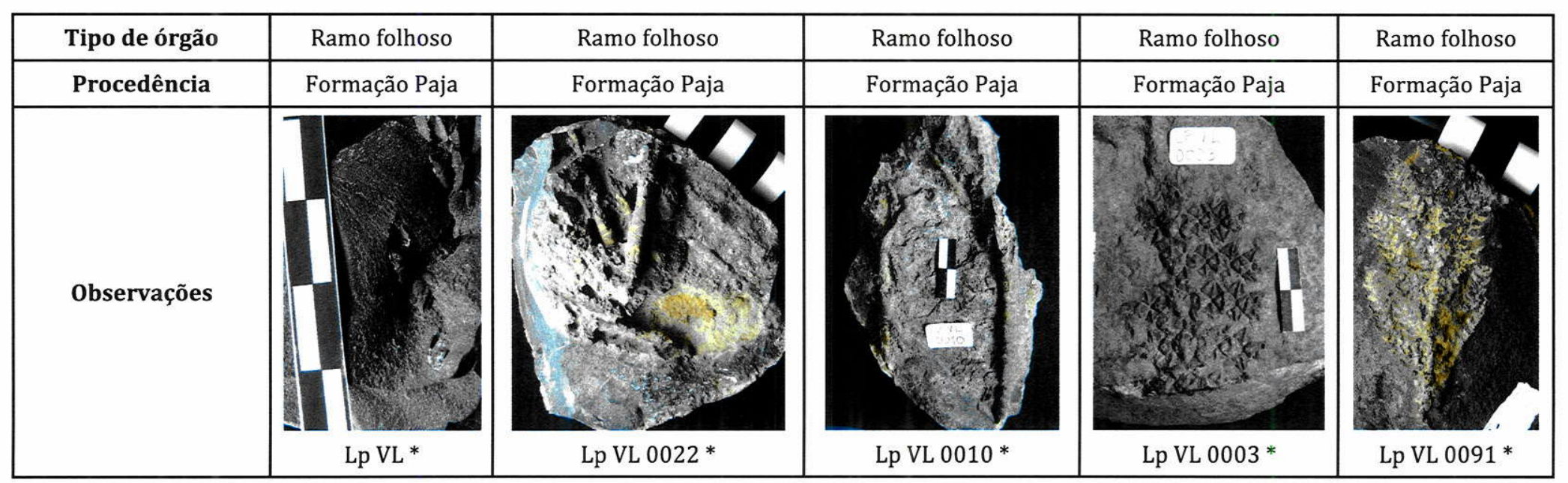




\begin{tabular}{|c|c|c|c|c|}
\hline Tipo de órgão & Cone & Cone & Cone & Complexo bráctea-escama \\
\hline Procedência & Formação Paja & Formação Paja & Formação Paja & Formação Paja \\
\hline \multirow[t]{2}{*}{ Observações } & & & & \\
\hline & Lp VL $0007^{*}$ & Lp VL $0051 *$ & Lp VL $0035^{*}$ & Lp VL $0038^{*}$ \\
\hline
\end{tabular}

K. Espécimes examinados da coleção Padre Huertas de la Universidad Nacional de Colombia, Bogotá, Colômbia.

\begin{tabular}{|c|c|c|c|c|c|c|}
\hline Tipo de órgão & Ramo folhoso & Ramo folhoso & Ramo folhoso & Ramo folhoso & Ramo folhoso & Ramo folhoso \\
\hline Procedência & Formação Paja & Formação Paja & Formação Paja & Formação Paja & Formação Paja & Formação Paja \\
\hline \multicolumn{7}{|l|}{ Observações } \\
\hline & $\begin{array}{c}\text { Thuites } \\
\text { venustus } \\
\text { (Holótipo) }\end{array}$ & Thuites frequens & $\begin{array}{l}\text { Thuites } \\
\text { frequens }\end{array}$ & Thuites frequens & Thuites frequens & Thuites frequens \\
\hline
\end{tabular}




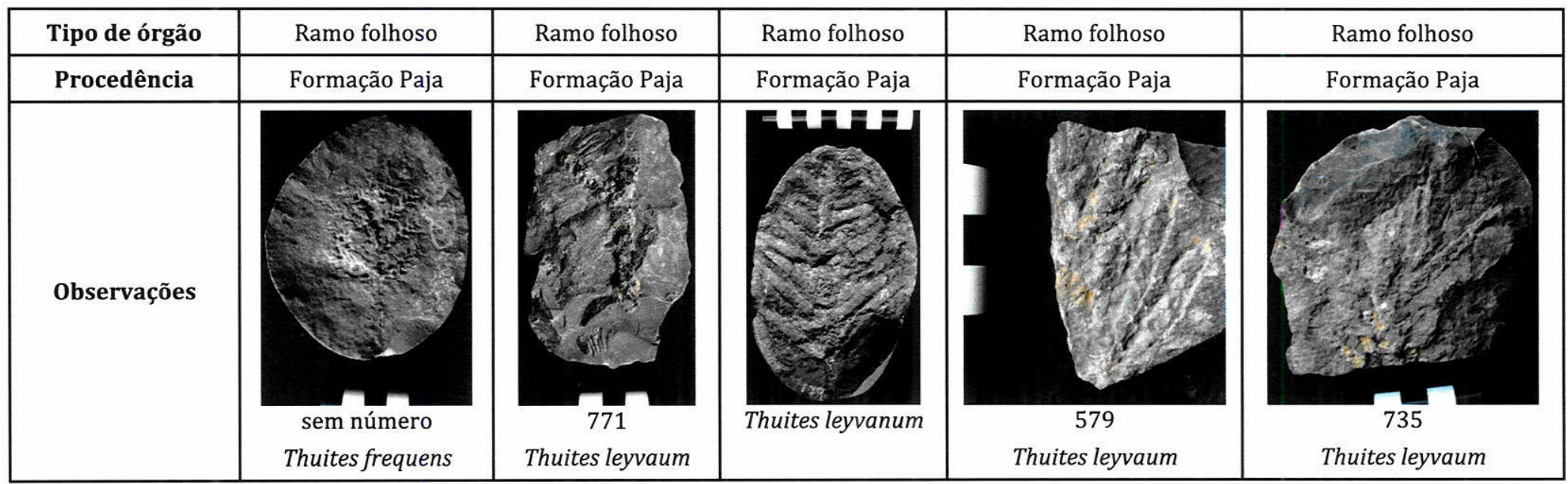

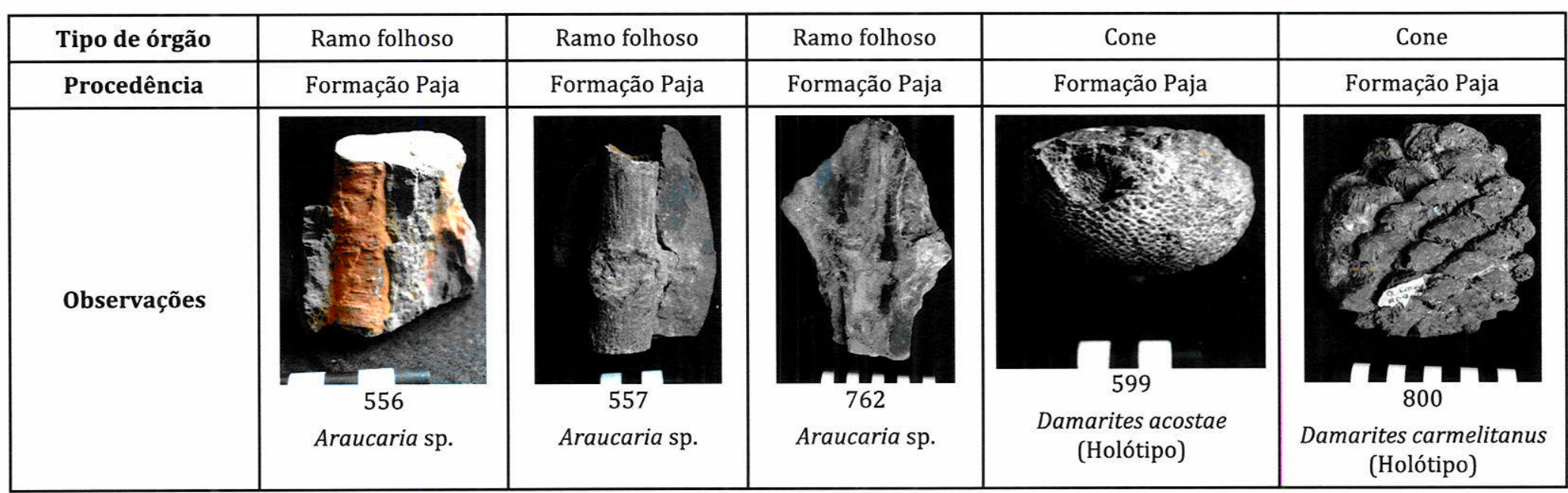




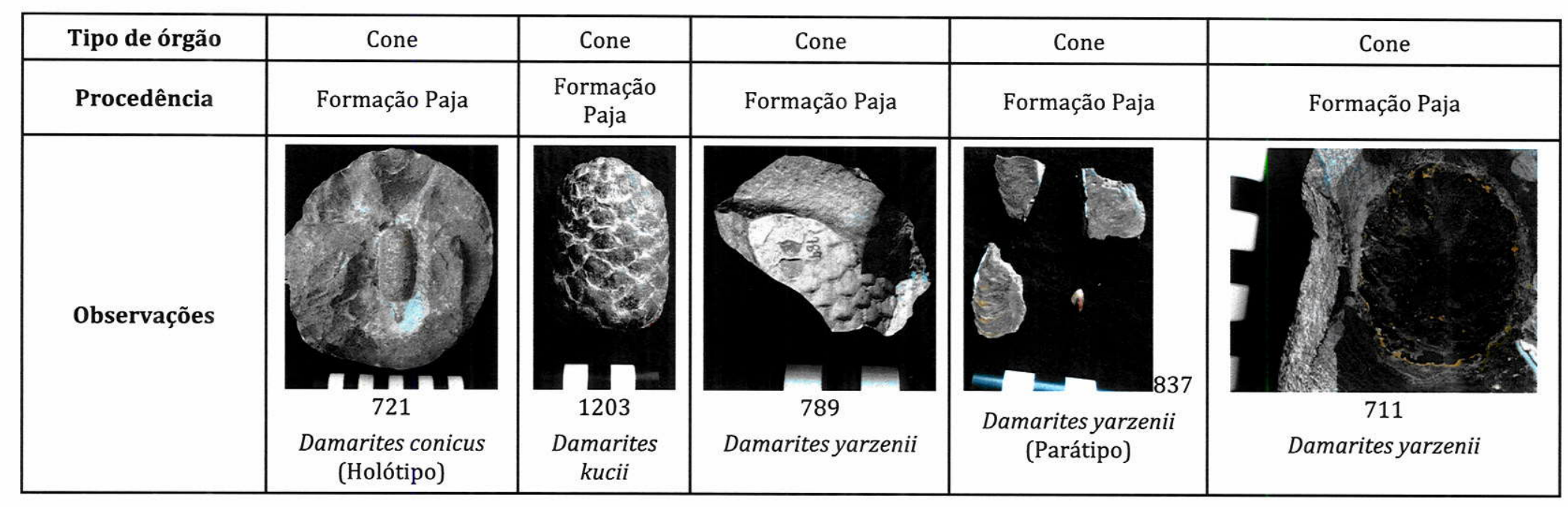

\begin{tabular}{|c|c|c|c|c|c|}
\hline Tipo de órgão & Cone & Cone & Cone & Cone & Cone \\
\hline Procedência & Formação Paja & Formação Paja & Formação Paja & Formação Paja & Formação Paja \\
\hline \multicolumn{6}{|l|}{ Observações } \\
\hline & 801 & 777 & 2171 & 2170 & 2082 \\
\hline & $\begin{array}{l}\text { Cycadeoidea } \\
\text { perpusilla } \\
\text { (Holótipo) }\end{array}$ & $\begin{array}{l}\text { Pytiostrobus } \\
\text { idroboi }\end{array}$ & $\begin{array}{c}\text { Pytiostrobus } \\
\text { sanctieccehomo (Holótipo) }\end{array}$ & Pinostrobus caldasii (Holótipo) & $\begin{array}{l}\text { Araucariostrobus } \\
\text { archangelskyi } \\
\text { (Holótipo) }\end{array}$ \\
\hline
\end{tabular}




\begin{tabular}{|c|c|c|c|c|c|}
\hline Tipo de órgão & Cone & Cone & Cone & Cone & Cone \\
\hline Procedência & Formação Paja & Formação Paja & Formação Paja & Formação Paja & Formação Paja \\
\hline \multicolumn{6}{|l|}{ Observações } \\
\hline & $\begin{array}{c}2082 \\
\text { Araucariostrobus } \\
\text { creutzbergi }\end{array}$ & $\begin{array}{c}2082 \\
\text { Araucariostrobus } \\
\text { protectus (Holótipo) }\end{array}$ & $\begin{array}{c}452 \\
\text { Araucariostrobus } \\
\text { protectus (Parátipo) }\end{array}$ & $\begin{array}{c}180 \\
\text { Araucariostrobus } \\
\text { camargoi (Holótipo) }\end{array}$ & $\begin{array}{c}180 \\
\text { Araucariostrobus } \\
\text { camargoi (Parátipo) }\end{array}$ \\
\hline
\end{tabular}

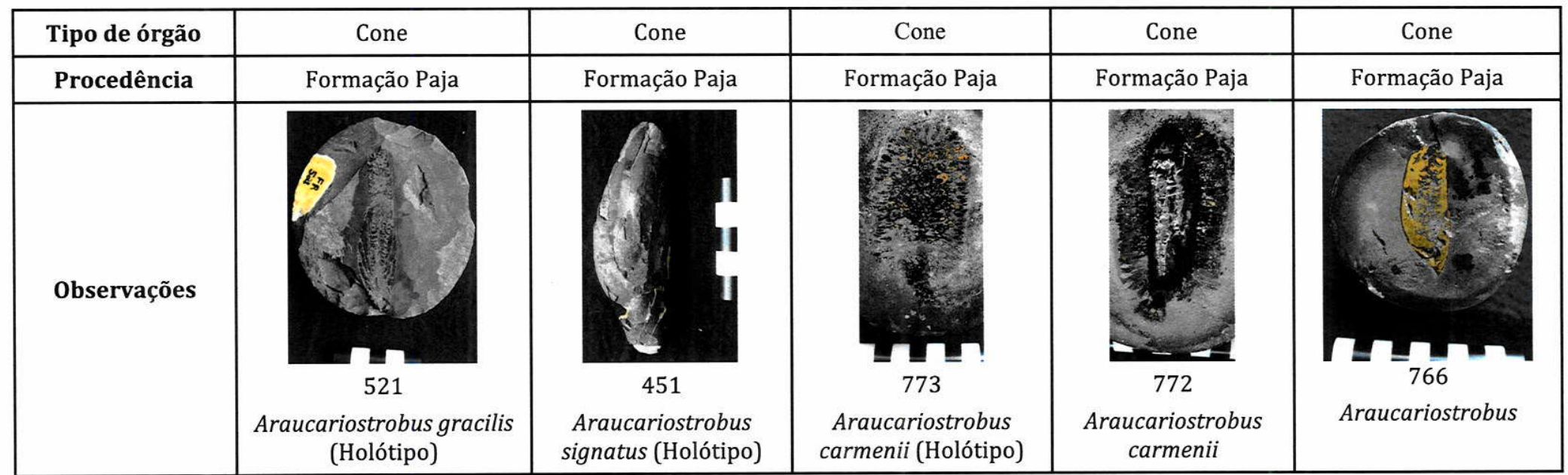




\begin{tabular}{|c|c|c|c|c|c|}
\hline Tipo de órgão & $\begin{array}{l}\text { Complexo bráctea- } \\
\text { escama }\end{array}$ & $\begin{array}{c}\text { Complexo } \\
\text { bráctea-escama }\end{array}$ & Complexo bráctea-escama & $\begin{array}{c}\text { Complexo } \\
\text { bráctea-escama }\end{array}$ & Complexo bráctea-escama \\
\hline Procedência & Formação Paja & Formação Paja & Formação Paja & Formação Paja & Formação Paja \\
\hline \multirow[t]{2}{*}{ Observações } & & & & & \\
\hline & $\begin{array}{l}596 \\
\text { Carpolithes sp. }\end{array}$ & $\begin{array}{c}597 \\
\text { Carpolithes } \\
\text { deltoideus } \\
\text { (Holótipo) }\end{array}$ & $\begin{array}{c}628 \\
\text { Carpolithes deltoideus } \\
\text { (Parátipo) }\end{array}$ & $\begin{array}{c}655 \\
\text { Carpolithes } \\
\text { perturbatrix } \\
\text { (Holótipo) }\end{array}$ & $\begin{array}{c}584 \\
\text { Carpolithes perturbatrix }\end{array}$ \\
\hline
\end{tabular}

\begin{tabular}{|c|c|c|c|}
\hline Tipo de órgão & $\begin{array}{c}\text { Complexo bráctea- } \\
\text { escama }\end{array}$ & $\begin{array}{c}\text { Complexo bráctea- } \\
\text { escama }\end{array}$ & Semente \\
\hline Procedência & Formação Paja & Formação Paja & Formação Paja \\
\hline Observações & & & \\
& & $\begin{array}{c}\text { Carpolithes incertus } \\
\text { (Holótipo) }\end{array}$ & $\begin{array}{c}\text { Carpolithes stigmatus } \\
\text { (Holótipo) }\end{array}$ \\
\hline
\end{tabular}




\section{GMail}

byciogole

\section{Acknowledgement of receipt of your submitted article}

Rev. Palaeobotany and Palynology <palbo-eo@elsevier.com>

Para: psucerquia@gmail.com

Dear Mrs. Sucerquia,

Your submission entitled "Phytogeographic, stratigraphic and paleoclimatic significance of Pseudofrenelopsis capillata sp. nov. from the Lower Cretaceous Crato Formation, Brazil" has been received by Review of Palaeobotany and Palynology

Please note that submission of an article is understood to imply that the article is original and is not being considered for publication elsewhere. Submission also implies that all authors have approved the paper for release and are in agreement with its content.

You will be able to check on the progress of your paper by logging on to http://ees.elsevier.com/palbo/ as Author.

Your manuscript will be given a reference number in due course.

Thank you for submitting your work to this journal.

Kind regards,

Review of Palaeobotany and Palynology 


\section{Elsevier Editorial System(tm) for Review of Palaeobotany and Palynology}

Manuscript Draft

\section{Manuscript Number:}

Title: Phytogeographic, stratigraphic and paleoclimatic significance of Pseudofrenelopsis capillata sp. nov. from the Lower Cretaceous Crato Formation, Brazil

\section{Article Type: Research Paper}

Keywords: Pseudofrenelopsis capillata; Cheirolepidiaceae; anatomy; climate sensitivity; Crato Formation; Early Cretaceous

Corresponding Author: Mrs. Paula Sucerquia,

Corresponding Author's Institution: Universidade de São Paulo

First Author: Paula Sucerquia

Order of Authors: Paula Sucerquia; Mary Elizabeth C Bernardes-de-Oliveira 
1 Phytogeographic, stratigraphic and paleoclimatic significance of Pseudofrenelopsis capillata sp. nov. from the Lower Cretaceous Crato Formation, Brazil

4 Paula Andrea Sucerquia ${ }^{a}$, Mary E.C. Bernardes-de-Oliveira ${ }^{\mathrm{a}, \mathrm{b}}$, Barbara A. R. Mohr

6 'Programa de Pós-Graduação em Geoquímica e Geotectônica, Instituto de Geociências,

7 Universidade de São Paulo, Rua do Lago 562, Cidade Universitária, CEP 05508-080,

8 São Paulo, SP, Brasil. psucerquia@gmail.com

9 bentro de Pós-Graduação e Pesquisa, Universidade Guarulhos, Av. Eng. Prestes Maia 88, Centro, CEP 07011-080, Guarulhos, SP, Brazil.

${ }^{c}$ Museum of Natural History, Collections, Invalidenstrasse 43, 10115 Berlin, Germany

Abstract

In the Early Cretaceous Coniferales are represented in northern South America both by macrofossils and palynomorphs of the families Araucariaceae and Cheirolepidiaceae,. The Cheirolepidiaceae, characterized by pollen grains of the genus Classopollis, is traditionally considered to be characteristic of coastal deposits, partly in semiarid to arid climates because anatomical features of Cheirolepidiaceae include several adaptations to aridity. Here anatomically preserved specimens of Pseudofrenelopsis from laminated limestones of the Crato Formation (Araripe Basin, NE Brazil), stored in various collections, were studied by light and scanning electron microscopy. A new species Pseudofrenelopsis capillata nov. sp. is described which seems to have grown exclusively at the Early Cretaceous (sub)paleoequatorieal area of South America and may be therefore endemic. The new taxon may have not grown in a nearshore 
environment, but along the shores of a large lake as a minor constituent of the surrounding vegetation.

Keywords: Pseudofrenelopsis capillata, Cheirolepidiaceae, anatomy, climate sensitivity, Crato Formation, Early Cretaceous.
1. Introduction

During the Early Cretaceous, global vegetation was dominated by gymnosperms including Coniferales, Bennettitales, Cycadales, Gnetales, Gingkoales and

Pteridospermales. All these groups, in addition to spore bearing pteridophytes and lycophytes, were affected by a rapid evolution of the angiosperms in the second half of the Cretaceous. Several of the gymnosperm groups became extinct or were dramatically reduced at the end of the period. The conifer family Cheirolepidiaceae did not surpass the K-T boundary, but was highly diverse, abundant and worldwide distributed during the Mesozoic.

The Family Cheirolepidiaceae has been traditionally defined by a single character: the morphology of pollen grains of the genus Classopollis Pflug (Doludenko, 1978;

Watson, 1988), formerly named Corollina Malyavkina or Circulina Malyavkina (Pocock and Jansonius, 1961; Traverse, 2004). Cheirolepidaceae range from the Late

4 Triassic to the Late Cretaceous (Reyre, 1973; Srivastava, 1976), with a cosmopolitan distribution, but minor abundance at high latitudes (Vakhrameev, 1970; Brenner, 1976).

6 The youngest member of Cheirolepidiaceae, Brachyphyllum patens seems to be 7 recorded in Maastrichtian sediments from the Maastrichtian type area (The Netherlands, Belgium) (Van der Ham et al., 2003). 
49 Classopollis is easily recognizable in the sporomorph assemblages. This pollen-type

50 occurs both single as well as in tetrads. When single, the grains have an approximately

51 spherical form, with a proximal triradiate scar and a distal cryptopore, where the exine

52 is thinner. The pollen also exhibits a circumpolar ridge or Rimula just above the equator

53 towards the distal pole. Around the equator, the exine is thickened, like a belt and is

54 usually ribbed on the inside (Srivastava, 1976; Watson, 1988). Classopollis pollen

55 grains bear diversified external sculptures and orbicules in the pollen grain surface, that

56 may be of taxonomic relevance (Reyre, 1970).

57 Abundant Classopollis in palynological assemblages has been considered to represent

58 coastal deposition under arid climatic conditions. It has been also used to define floristic

59 regions and arid areas (Vakhrameev, 1991). Some specimens representing vegetative

60 parts of this family have morphological characteristics indicating that they grew in an

61 arid or at least seasonally dry habitat (Watson, 1988). Its decline at the end of the

62 Cretaceous period may be related to less severe weather conditions, when the global

63 climate was overall cooler and at low latitudes with higher precipitation rates.

64 The paleogeographic distribution of Cheirolepidiaceae macrofossils when compared to

65 other paleoclimatic indicators also reveals that representatives of this family lived

66 mostly in hot and/or dry climates (Vakhramev, 1970), with maximum abundances

67 related to stratigraphic intervals and regions showing lithologic and paleobotanical

68 evidence of aridity expressed as red beds and/or evaporites, low diversity of ferns

69 and/or low diversity of large leaved gymnosperms. The xeromorphic nature of

70 Cheiroleps is supported by the morphology of their macrofossils, with reduced leaves,

71 very thick cuticle, sunken stomata and fleshy appearance of branches and leaves

72 (Upchurch and Doyle, 1981). 
73 Although representatives of this family show a strong xeromorphic appearance, the

74 vegetative morphology of this family is highly variable, with two types of leafy

75 branches, the Brachyphyllum-Pagiophyllum type with adpressed and fleshy or falcate

76 leaves, in spiral arrangement and the Frenelopsis-Pseudofrenelopsis type with leaves

77 arranged in whorls of apparently articulated stems, also known as frenelopsids (Watson,

78 1988; Axsmith et al., 2004). Brachyphyllum-Pagiophyllum type twigs are found almost

79 during the entire Mesozoic globally distributed, while the frenelopsids seem to be

80 restricted to the Early Cretaceous, of North America, Europe, Africa, Asia and South

81 America, and are frequently used as environmental indicators of tropical to subtropical

82 arid climate (Alvin, 1982).

83 In South America, frenelopsids are recorded from the Crato and Romualdo Formations,

84 Araripe Basin, northeastern Brazil, as Frenelopsis sp. (Kunzmann et al., 2006), in the

85 Paja Formation, Colombia, as two forms of Pseudofrenelopsis and one of Frenelopsis

86 (Moreno-Sanchez et al., 2007)

87 The ages of these three lithological units range from the Aptian to early Albian and

88 share paleofloras composed of abundant conifers of the families Araucariaceae and

89 Cheirolepidiaceae, including vegetative and reproductive remains. However, fossils of

90 the genus Pseudofrenelopsis have not been found in organic connection with

91 reproductive structures, but there are several male and female cones in the Crato and

92 Paja Formations that have not been classified to date.

93

94 2. Geological setting

95 The Crato Formation is an Upper Aptian lithologic unit of the Araripe Basin. This basin

96 extends over an area of approximately $8000 \mathrm{~km}^{2}$ between $38^{\circ} 30^{\prime}-40^{\circ} 50^{\prime} \mathrm{W}$ longitude 
97 and $7^{\circ} 05^{\prime}-7^{\circ} 50^{\prime} \mathrm{S}$ latitude, occupying parts of the States Piauí, Ceará, Pernambuco and

98 Paraiba in a nearly rectangular shape, with a EW longitudinal axis (Figure 1). It is

99 formed by Paleozoic and Mesozoic sedimentary sequences covering the Precambrian

100 basement. Its origin and evolution are related to the tectonic events responsible for the

101 fragmentation of Gondwana, separating the South American and South African plates

102 and the consequent establishment of the South Atlantic Ocean (Ponte and Ponte Filho,

103 1996).

104 The Crato Formation is composed of laminated limestones interbedded with siltstones and fine sandstones deposited in a lacustrine environment. The paleolake, which gave rise to this unit, developed under a tropical-subtropical paleoclimatic regime (Neumann et al., 2003). The water body was permanently stratified with hypersaline and anoxic bottom waters, but well-mixed and productive in the surface waters (Heimhofer and Martill, 2007). Halite pseudomorphs and lack of indicators of benthonic life has been interpreted as evidence of a bottom brine in the lacustrine system (Neumann et al.,

111 2003).

112 The age of the Crato Formation, based on palynological studies, is considered to be Late 113 Aptian (Pons et al., 1990), belonging to the Cytheridea Ostracozone (NRT-011) and

114 Sergipea variverrucata Palynozone (P-270), which determine the Meso-Alagoas

115 (Brazilian local stage) age, that corresponds to the Late Aptian (Arai et al., 2001).

116 The fossil assemblage of the Crato Formation contains abundant insects, fishes, and

117 plants. Macro and microfloral remains are diverse, including specimens assigned to

118 ferns, conifers, gnetales and angiosperms. About 70-80 taxa are estimated to occur

119 there. Approximately $60 \%$ are gymnosperms, $30 \%$ are angiosperms and approximately $10 \%$ are pteridophytes (Mohr and Friis, 2000). Gymnosperm pollen are also dominant, 
121 with $52 \%$ against $32 \%$ of the species richness of ferns and $16 \%$ of angiosperms (Lima, 122 1978). Among the gymnosperms Gnetales and conifers of the families Araucariaceae

123 and Cheirolepidiaceae are the most significant components in both, macro and

124 microflora of the Crato Formation. However, macrofossils of Cheirolepidiaceae are

125 very rare compared to the remains of Araucarians of which hundreds of specimens are

126 stored in various collections. Cheirolepidaceae comprise besides very few specimens of

127 frenelopsids rare examples last order twigs of Tomaxellia (Kunzmann et al., 2006) and

128 more commonly branches of several orders of Duartenia (Mohr et al. 2012), both most

129 likely endemic to south America (Archangelsky and del Fueyo 2010; Mohr et al. 2012).

130 While the branches of Duartenia are usually very abraded and may thus come from the

131 hinterland, the rare specimens of Pseudofrenelopsis and Tomaxellia are usually

132 somewhat better preserved. This indicates that the two latter taxa may have grown

133 relatively near the place of their final burial.

135 3. Material and methods

136 The fossil plants are preserved in light yellow to grayish brown laminated limestones,

137 preserved as coalified compressions with cuticles, iron oxides casts with epidermal and

138 anatomic features and impressions. Most of the fossils were presumably extracted from

139 Pedra Cariri quarries located between the towns Santana do Cariri and Nova Olinda in

140 the State of Ceará, Brazil.

141 The studied material is housed in the paleobotanical collection of the Museum für

142 Naturkunde der Humboldt-Universität, Berlin (Mb.Pb. 2002/1344), in the scientific

143 collection of the Departamento de Geologia Sedimentar, Instituto de

144 Geociências/Universidade de São Paulo (GP/3E 9118, GP/3E 9380), and at the 
scientific collection of the Instituto de Geociências, Universidade Federal de Rio de Janeiro (UFRJ Pb 428a-b, UFRJ PbA 858a-b). The frenelopsid specimen SM.B.16447

147 (Senckenberg Forschungsinstitut und Naturmuseum, Frankfurt), figured and described

148 by Kunzmann et al., (2006) as, Frenelopsis sp., was also reviewed.

149 The fossils were studied under a ZEISS Stemi SV6 Stereomicroscope with

150 magnifications from 8 to $200 \mathrm{X}$. Photomacrographs were taken with a Canon EOS

151 Rebel T2i, with 18 MP.

152 Material with preserved anatomical details was studied on SEM. Little fragments of

153 fossils preserved in iron oxide preservation were removed from the specimens and

154 mounted on stubs with carbon conductive tape, then covered with a 100-200 nanometers

155 gold layer. Photographs were taken at a LEO 440 I Scanning Microscope.

156 Cuticles were detached from fossils with needle and treated with $100 \%$ nitric acid

$157\left(\mathrm{HNO}_{3}\right)$ a $100 \%$, for about 24 hours, later with $10 \%$ potassium hydroxide $(\mathrm{KOH})$. After

158 washing in distilled water, a dehydratation with ethylic alcohol was necessary for

159 coloration with safranin in alcoholic solution. These cuticles were mounted on slides

160 with Entellan. The cuticles were analised in a Carl Zeiss Axiophot II microscope, and

161 photomicrographs taken with a digital camera Sony Cyber Shoot DSC-S75 de 3,3

162 megapixels attached to the microscope. Non colored cuticles was analyzed with the

163 SEM following the same procedure as described for the iron oxide fragments.

164

165 4. Systematic palaeobotany

166 Kingdom Plantae

167 Division Tracheophyte

168 Class Gymnospermopsida 
170 Family Cheirolepidiaceae Takhtajan

171 Genus Pseudofrenelopsis Nathorst

172 Pseudofrenelopsis capillata sp. nov.

173 Synonymes:

174 Frenelopsis sp. Kunzmann, Mohr, Bernardes-de-Oliveira and Wilde, pp. 218, Figs. 3A-

175 C, 4A-E, 5A-G, 2006.

176 Holotype: Specimen MB.Pb.2002/1344 and cuticles extracted from it.

177 Repository: Specimen in the Paleobotanical Collection of the Museum für Naturkunde

178 der Humboldt-Universität, Berlin, preparations of the cuticles are stored at the scientific

179 collection of the Departamento de Geologia Sedimentar, Instituto de

180 Geociências/Universidade de São Paulo.

181 Type locality: Laminated limestone (Pedra Cariri) quarries between the towns Nova

182 Olinda and Santana do Cariri, State of Ceará, Brazil.

183 Stratigraphic horizon: Crato Formation

184 Age: Late Aptian

185 Etymology of the specific epithet: capillata - Latin adjective for organism/bodies

186 endowed with hairs.

187 Specific diagnosis: Shoots articulated with short and long internodes occuring at the

188 same branch, short internodes in basal position of the branch. Woody axis about $1 / 3$ of

189 the width of shoot. One leaf per node in a $2 / 5$ spiral phyllotaxy. Leaves enclosing the

190 stem, without visible suture and with free triangularly shaped tip.. Apical edges of

191 leaves covered with densely unicellular unusually long hairs. Abaxial cuticle with

192 stomata in well defined longitudinal uniseriate rows, adjacent or separated by 1-3 
ordinary epidermic cells. Upper surface of the cuticle composed of papillate epidermal cells. Stomatal complex circular in outline, 5-6 strongly papillate subsidiary cells of trapezoidal shape. Solid and rounded papillae covering the stomatic pit. Guard cells elongated with inner straight edges. Stomatal pits oriented mostly obliquely, sometimes perpendicularly. Stomata less frequent at the leaf apex and base. Ordinary epidermal

198 cells elongated between the stomatal rows and polygonal within them. Abaxial cuticles

199 at internodes remarkably thick. Anticlinal walls of epidermal cells thick. Wood with 200 tracheids, helical thickenings, uniseriate adjacent areolate pits and cross-field pitting of 201 the cupressoid type. Remarks: The new species is similar to P. papillosa and to P. parceramosa with which it shares the character of having (long) hairs on the outer adaxial cuticle. However in P. capillata and $P$. parceramosa the hairs exceed those of $P$. papillosa clearly in length.

206 At the leaves' upper margin $P$. capillata develops longer hairs than $P$. papillosa and $P$.

207 parceramosa. In $P$. parceramosa the outer abaxial cuticle is however without hair 208 and/or papillae. $P$. capillata has relatively thick cuticles (at the internodes), but $P$. 209 parceramosa exceeds the cuticle thickness of the new species clearly (see discussion).

211 Paratypes: GP/3E 9118, GP/3E 9380 (Departamento de Geologia Sedimentar, Instituto 212 de Geociências/Universidade de São Paulo), UFRJ Pb 428a-b, UFRJ PbA 858a-b

213 (Instituto de Geociências, Universidade Federal de Rio de Janeiro), SM.B.16447, 214 SM.B.16486 (Senckenberg Forschungsinstitut und Naturmuseum, Frankfurt) 
216 Description: All the specimens are either unbranched or branched shoots (PL I, 1, 7, 9),

217 preserved as coalified compressions with cuticles (MB.Pb.2002/1344 and GP/3E 9118),

218 iron oxide casts (GP/3E 9380, UFRJ Pb 428a-b, UFRJ PbA 858a-b) and impressions

219 (SM.B.16447).

220 Branched shoots comprise up to four orders (PL I, 1), the phylotaxy of branches is

221 apparently helicoidal. Divergence angles range between $22.5-53^{\circ}$. The shoots are

222 articulated, with internodes' length ranging between $3.5-5 \mathrm{~mm}$ and 7-9.5 $\mathrm{mm}$ at long

223 internodes, and diameter/width ranges between 4-8 $\mathrm{mm}$. Sequences of short and long

224 internodes are found on the same branch, with the short internodes more basal to the

225 branch. There is a single leaf per node in a $2 / 5$ spiral phyllotaxy arrangement (PL I, 2,

226 3). The leaves enclose the stem and are always of a closed type, without visible suture.

227 A free tip of the leaf arises from the node, overlapping the following leaf, the tips have

228 triangular shapes and a hight of $1-2 \mathrm{~mm}$ forming a $70-95^{\circ}$ angle at the apex (PL I, 4, 6).

229 Longitudinal lines correspond to stomatal rows which are visible in the external leaf

230 surface, resembling striae and converge towards the apex. The stele is about $1 / 3$ of the

231 width of shoot and is threedimensionally preserved in iron oxide specimens (PL I, 8).

232 The apical edge is densely covered with very long hairs, those are unicelular ranging

$233 \quad 60-240 \mu \mathrm{m}$ long. Width at the base of individual hairs is $21-29 \mu \mathrm{m}$ and gradually tapers

234 towards the tip (PL I, 5; PL II, 1-3).

235 In the abaxial cuticle, the stomata are arranged in well defined longitudinal uniseriate

236 rows, with stomata adjacent or separated by up to three rows of ordinary epidermic cells

237 (PL II, 4, 6). Laterally adjacent stomata may also occur; when they are adjacent never

238 share subsidiary cells (PL II, 7). In general, 7-9 rows of stomata occur per millimeter,

239 with a density of 70 stomata $/ \mathrm{mm}^{2}$. The upper surface of the cuticle shows epidermal 
cells, each bearing one rounded papillae in periclinal walls (PL II, 4-5). Papillae have a

241 diameter of 14-18 $\mu \mathrm{m}$ and a height of $10-13 \mu \mathrm{m}$.

242 The stomatal complexes have circular outlines and diameters of 66-91 $\mu \mathrm{m}$, with 5-6

243 strongly papillate subsidiary cells of trapezoidal to pentagonal shape, that are convex in

244 the widest area (PL III, 1, 4). Subsidiary cells measure 26-34 $\mu \mathrm{m}$ in length and 32-53

$245 \mu \mathrm{m}$ in width at the widest point. The papillae protrude from anticlinal walls of

246 subsidiary cells; they are solid, rounded and cover often completely the stomatic cavity

247 (PL III, 2-3). Guard cells are elongated, almost rectangular of 40-53 $\mu \mathrm{m}$ in length, with

248 inner straight edges of $2 \mu \mathrm{m}$ thickness (PL III, 1). Stomatal pits are oriented mostly

249 obliquely, sometimes perpendicularly to the rows but never parallell (PL II, 6; PL III,

250 4). The ordinary epidermal cells of the major part of the leaf are arranged in rows, $2-3$

251 cells between the stomatal rows and none to 4 cells between rows of stomata (PL II, 4 ,

252 6; PL III, 4). At the leaf apex and base, stomata become less frequent and guard cells are

253 preserved closed. Anticlinal walls of epidermal cells are 5-10 $\mu \mathrm{m}$ thick at almost the

254 entire leaf. The abaxial cuticle has a thickness of approx. $16 \mu \mathrm{m}$ (PL III, 6).

255 In the adaxial cuticle, stomata are very scarce (PL IV, 1), with guard cells closed and

256 papillae in subsidiary cells were therefore not observed. Epidermal cells are tetragonal

257 and bear hairs, one per cell, with up to $180 \mu \mathrm{m}$ length (PL IV, 1-2), the hair base

258 extends over the entire area of the periclinal wall.

259 The stem shows tracheids with helical thickenings and uniseriate adjacent areolate pits

260 (PL IV , 3). Cross field pitting are of the cupressoid type with more than 10 pits/ per

261 field and 4.5-6 $\mu \mathrm{m}$ in diameter arranged in rows of three to five pits (PL IV, 4).

262

263 5. Discussion 
All specimens from the Crato Formation are here considered to belong to the genus Pseudofrenelopsis. Based on the definition of Watson (1977), this genus has a single leaf per node and the leaves form a single spiral along the branch; leaves of the genus Frenelopsis have a whorled arrangement (3 leaves per whorl) and are rarely distichous. Kunzmann et al. (2006) assigned the specimen SM.B.16447 to the genus Frenelopsis based on the sutureless leaves - according to Srinivasan (1995) not a reliable character and the presence of two leaves per node. The specimen SM.B.16447 is relatively poorly preserved and leaf tips are mostly abraded. Therefore Kunzmann et al. (2006) were not able to establish the exact number of leaves per whorl. In this study the specimen SM.B.16447 was restudied, and based on the additional specimens now available and new observations the generic assignment is altered, and the specimen is now considered to belong to the genus Pseudofrenelopsis.

The genus Pseudofrenelopsis is currently known to have nine species: P. varians, upper

277 Aptian to lower Albian of Texas, United States (Watson, 1977); P. parceramosa,

278 Barremian to Aptian of Virginia, United States (Watson, 1977); upper Aptian to lower

279 Albian of Louisiana, United States (Watson, 1977); Aptian to Albian of Arkansas,

280 United States (Axsmith, 2006); Berriasian to Aptian of England (Watson, 1977);

281 Hauterivian to lower Barremian of Krakovia (Reymanówna and Watson, 1976); Aptian

282 to Albian of Portugal (Alvin, 1977); Lower Cretaceous of Sudan (Watson and Alvin, 283 1976; Watson, 1983); Hauterivian (not younger than lower Barremian) of Moravia 284 (Hlustik, 1988); P. papillosa, Lower Cretaceous (older than Aptian) of China (Zhou, 285 1995); P. dalatzensis, Aptian to Albian of China (Zhou, 1995); P. heishanensis, Lower 286 Cretaceous (older than Aptian) of China (Zhou, 1995); P. nathorstiana, Potomac Group, 287 lower to middle Aptian of Virginia, United States (Srinivasan, 1995); P. glabra, Albian 
of Hokkaido, Japan (Saiki, 1999); P. gansuensis, Barremian of China (Deng et al., 2005); P. guixiensis, Lower Cretaceous of China (Sun et al., 2011).

Comparing morphological characters of vegetative remains and epidermal features of the Pseudofrenelopsis specimens of the Crato Formation with descriptions of species of the same genus already established, it has become obvious that $P$. capillata sp. nov. shares most of the characters with them, but does not fit completetly in any diagnosis of the hithertho known species (Tables 1, 2, 3). The main difference is the presence of very long hairs at the leaves' apical edges (up to $240 \mu \mathrm{m})$, the longest for the genus. Another unique character is the presence of long and abundant hairs on the adaxial cuticle. Only in P. parceramosa the presence of very long hairs at adaxial cuticle (Watson, 1977) is documented, but hairs at the leaf apex are considerably shorter (up to $60 \mu \mathrm{m}$ ). Despite this, a thorough comparison was made with that species because of its wide range of character variation, its wide latitudinal and longitudinal geographic distribution (Figure 2, Tables 1,2,3) and also because it is the only one to date that has been recorded at low latitudes, more precisely in the Sudan, northern Africa (Watson and Alvin, 1976; Watson, 1983).

304 When comparing the new species $P$. capillata with the diagnosis and descriptions of

305 the most widespread taxon of the western hemisphere P. parceramosa (Watson, 1977),

306 it is obvious. that the new taxon shares several features with P. parceramosa. Among

307 them are the distribution of stomata in rows and the notable thickening of the anticlinal

308 walls in the epidermal cells. Inside the rows, stomata are partly separated by

309 isodiametric epidermal cells or are adjacent. Papillae are present in anticlinal walls of

310 subsidiary cells and protrude to the stomatal opening. A dense hair cover is observed at

311 the free leaf tips and the presence of branches with both, long and short internodes. 
312 Anatomical features such as areolate uniseriate pits and cross fields are very similar to

313 those described for P. parceramosa by Alvin et al. (1981).

314 When compared to P. parceramosa specimens, housed at the American Museum of

315 Natural History (PAL 192360, PAL 192362, PAL 192363, PAL 192393), it was

316 observed that, in accordance with the species diagnosis, the leaves show no evidence of

317 suture, as seen in specimens of $P$. capillata. Another shared feature, not described in the

318 diagnosis or any other description for P. parceramosa, is the presence of shorter

319 internodes immediately after branching, becoming longer distally to the branching

320 point. The branch phyllotaxy, described as alternate and bilateral in P. parceramosa,

321 was observed to be helical in the specimens as in P. capillata. The ratio of the diameter

322 of the main axis and the diameter of side branches of higher order, is very remarkable in

323 P. parceramosa, reaching 5:3, while in P. capillata the ratio is minimal. Possibly the

324 variations of the ratio may be related to the position of these branches on the plant.

325 Stomata of both species are arranged in uniseriate rows, with usually 5-6 subsidiary

326 papillate cells protruding to the stomatal cavity, with cell walls thinner than those of

327 ordinary epidermal cells. The epidermal cell walls are thick on both species, but in $P$.

328 capillata, they do not show thickening in anticlinal walls of cells separating the rows of

329 stomata. Brazilian species lack well developed and cutinized hypodermal cells observed

330 in P. parceramosa. However, in specimens of the same species from Arkansas (USA)

331 this feature is also absent (Axsmith 2006). Cuticle thickness in P. capillata is about 16

$332 \mu \mathrm{m}$, almost half of the cuticle's thickness $(30 \mu \mathrm{m})$ of $P$. parceramosa.

334 6. Phytogeography, stratigraphy and climate 
335 The occurrence of the genus Pseudofrenelopsis in the Araripe Basin, Brazil, constitutes

336 the southernmost record of this genus, extending its latitudinal distribution (Figure 2).

337 The approximate geographic locations of Pseudofrenelopsis' ocurrences is plotted on an

338 Aptian paleogeographic and paleoclimatic map (Chumakov et al., 1995 in Hay and

339 Floegel, 2012). When compared to the floristic regions of Vakhrameev (1991), most of

340 the records of this genus are located in the Euro-Sinian Region, while only two belong

341 to the (sub)Equatorial Region, of Brazil in South America and the Sudan in Africa and

342 are located in the evaporitic belt within the arid zone (Chumakov et al., 1995) for the

343 Aptian (Figure 2).

344 The stratigraphic distribution, of Pseudofrenelopsis species, ranges from the Berriasian

345 to Albian, but during the Aptian the genus seems to experience its greatest diversity

346 (Figure 3).

347 In relation to paleoclimatic and paleoecological aspects, there seems to be a consensus

348 among the different paleoenvironments interpreted for species of the genus

349 Pseudofrenelopsis. In the Lower Cretaceous of Texas, USA, $P$. varians has been

350 generally associated with environments of high salinity and evaporation rates, mainly

351 based on the xeromorphic features of their leaves (eg. thick cuticle and sunken stomata),

352 but also on the sedimentological characteristics of the deposits (Daghlian and Person,

353 1977). This species was reconstructed as a succulent, similar to the extant halophytic

354 angiosperm Salicornia (Watson, 1977, 1988).

355 The leaf morphology of $P$. parceramosa from various localities, is interpreted as a

356 xeromorphic adaptation to arid climates (Watson, 1977, 1988, Alvin, 1982, 1983;

357 Axsmith et al., 2004). Moreover, Upchurch and Doyle (1981), based on

358 sedimentological data, macrofossils and palynological diversity of the Potomac Group, 
indicated a coastal tide influenced environment for $P$. parceramosa interpreting this taxon as a facultative halophyte. The same authors report also for the Potomac Group another taxon of Cheirolepidiaceae with similar morphological characteristics, Frenelopsis ramosissima, as associated to non-saline environments. Frenelopsids show a wide ecological amplitude. Their habitat include non-saline environments as recorded in Spain. Xeromorphic features of the genus Frenelopsis are certainly not always related to a coastal environment but to climate induced water-stress (Gomez et al., 2002). P. parceramosa from the Lower Cretaceous of the Isle of Wight (England), occupied

367 the margins of braided rivers (Alvin et al., 1981),. According to this authors a climate

368 regime with high precipitation prevailed during the formation of this deposits, but the

369 presence of fusinized woods associated to irregular growth rings in stems indicate 370 occasional or periodic dry phases, probably severe enough to allow forest fires. Alvin 371 (1983) concludes in a study of material from the same locality that the morphological

372 features of $P$. parceramosa are most likely due to xeromorphism, not to halophytism, 373 since there is no evidence of any marine influence. Contrary to this statement, Haworth 374 and McElwain (2008), consider that "xeromorphic" features in Pseudofrenelopsis

375 parceramosa are not related to real xeromorphy but constitute adaptations to 376 environmental stress of differing origins as can be volcanism, wind or predators.

377 Low diversity of palynological and macrofloristic assemblages in the Holly Creek

378 Formation in Arkansas, USA (Axsmith et al., 2004) are considered to represent a highly

379 stressful environment. But it is not clear whether this is the result of environmental 380 stress caused by drought, saline influence or combination of both factors.

381 Sedimentological evidence such as red beds in sequences containing $P$. parceramosa 382 and evaporites in stratigraphically nearby strata may confirm xeric conditions. Marine 
influence was also proven in associated sediments. At the Arkansas locality, as well as in Lower Cretaceous strata of the Isle of Wight, the fossils have xeromorphic features and moreover fusinized wood particles and stems with irregular growth rings, suggest wildfires and occasional hydric stress.

Apparently, the broad ecological tolerance of $P$. parceramosa, which may have led to the divergent paleoecological interpretations, may be the consequence of a low taxonomic resolution, proven by the presence of at least two types of male cones considered to belong to the same plant that produces branches of this species. However, Classostrobus arkansensis (Asxmith et al., 2004) is the only one attached to Pseudofrenelopsis parceramosa shoots, while Classostrobus comptonensis (Alvin et al., 1978) is closely associated and shares similarities in cuticular characteristics. The sedimentological characteristics of the Crato Formation, do not disagree with the interpretation of the ecologic niche in which the genus Pseudofrenelopsis grew. The environmental interpretations for this lithological unit suggests a lake with hypersaline conditions at the bottom (Neumann et al., 2003), and proximity to evaporitic deposits. Pseudofrenelopsis guixiensis is considered to have grown in hyperhaline soils based on the association with gypsum beds of the rocks containing $P$. guixiensis and the lack of evidence of long distance transport for those plant remains.

401 Pseudofrenelopsis capillata, may have been the only species growing most likely not

402 directly at a coastal line, but at the shores of a large lake. There moisture coming from 403 oceans may not have penetrated, a phenomenon known as the Super Continent Effect 404 (Hay and Floegel, 2012) and therefore also arid conditions may have prevailed during much of the year. In any case, the climate regime was, based on various proxies, 
certainly at least seasonally dry with episodes of high precipitation and restricted

407 (haline) bottom water conditions (Martill et al., 2007; Heimhofer et al. 2009).

408 It is not clear if the xeromorphic morphology and anatomy of Pseudofrenelopsis

409 capillata is conditioned by aridity and/or salinity, since its paleogeographic position and

410 the nature of the sediments indicate seasonally dry arid climate regimes as well as

411 hypersaline water bodies.

413 7. Conclusions

414 Based on comparison with the character sets of the Pseudofrenelopsis species known to

415 date (Tables 1, 2, 3), we conclude that is not possible to fit the specimens studied here

416 in any of the hithertho described species. Therefore a new species, Pseudofrenelopsis

417 capillata Sucerquia, Bernardes-de-Oliveira and Mohr is proposed. Although

418 reproductive organs have not been found associated or in connection to

419 Pseudofrenelopsis capillata shoots, a new species is justified based on various cuticular

420 features that diverge from those described for all the other species of the genus (seen in

421 (Tables $1,2,3$ ) or are not presente in this particular combination The most distinct

422 character is the presence of very long hairs on apical edges of leaves and on the adaxial

423 cuticle. Its isolated paleogeographic position may support the proposal of a new species

424 at the Cretaceous (sub)paleoequatoreal region (northeastern part of Brazil). The new

425 species was a rare constituent of the vegetation along the lake shore and was adapted to

426 seasonally dry and/or haline conditions.

428 Acknowledgments 
429 The authors would like to acknowledge the collaboration of Lutz Kunzmann

430 (Senckenberg Naturhistorische Sammlungen, Dresden) for help with the access to

431 collections with previously described specimens of the Crato Formation. Thanks also to

432 Dr. Ismar de Souza Carvalho (Instituto de Geociências, Universidade Federal de Rio de Janeiro) for the loan of the specimens UFRJ Pb 428a-b and UFRJ PbA 858a-b. John Wingerath (Paleobotany Collections of the American Museum of Natural History, Washington) was so kind to provide access to North American and England specimens and mounted cuticles. We also would like to thank to Dr. Brian Axsmith (University of South Alabama, Mobile) for the possibility to study North American vegetative and reproductive specimens, and for the supply of cuticular material for detailed comparisons. Thanks also go to Yohana Villafañez (Universidade de São Paulo), who helped with the preparation of figures. The first author would like to acknowledge the

financial support for a scholarship and research funds provided by the Fundação de

Amparo a Pesquisa do Estado de São Paulo (FAPESP Proccess 2008/02884-5).

References

Alvin, K.L., 1977. The conifers Frenelopsis and Manica in the Cretaceous of Portugal.

446 Palaeontology 20, 387-404.

Alvin, K.L., 1982. Cheirolepidiaceae: biology, structure and paleoecology. Review of Palaeobotany and Palynology 37, 71-98.

Alvin, K.L., 1983. Reconstruction of a Lower Cretaceous conifer. Botanical Journal of the Linnean Society 86, 169-176.

Alvin, K.L., Spicer, R A., Watson, J., 1978. A Classopollis containing male cone associated with Pseudofrenelopsis. Palaeontology 21, 847-856.

Alvin, K.L., Fraser, C.J., Spicer, R.A., 1981. Anatomy and Palaeoecology of Pseudofrenelopsis and associated conifers in the English Wealden. Palaeontology 24 
Arai, M., Coimbra, J.C., Silva-Telles, A.C., 2001. Síntese bioestratigrafica da Bacia do Araripe (Nordeste do Brasil). In: Simpósio sobre a Bacia do Araripe e Bacias Interiores
do Nordeste, I, Crato, 1990. Comunicações e Bacias Interiores do Nordeste, Crato, 109-118.

Archangelsky, S., Del Fueyo, G.M., 2010. Endemism of Early Cretaceous conifers in western Gondwana. In: Gee, C. (ed.) Plants in Mesozoic Time: Morphological
innovations, phylogeny and ecosystems. Indiana University Press.

Axmith, B.J., Krings, M., Waselkov, K., 2004. Conifer pollen cones from the Cretaceous of Arkansas: Implications for diversity and reproduction in the Cheirolepidiaceae. Journal of Paleontology 78, 402-409.

Axsmith B.J., 2006. The vegetative structure of a Lower Cretaceous conifer from Arkansas: Further implications for morphospecies concepts in the Cheirolepidiaceae.
Cretaceous Research 27,309-17.

Brenner, G.J., 1976. Middle Cretaceous floral provinces and early migrations of Angiosperms. In: C.B. Beck (ed.), Origin and early evolution of angiosperms. Columbia
University Press, New York, USA, pp. 23-47. Chumakov, N.M., Zharkov, M.A., Herman, A.B., Doludenko, M.P., Kalandadze, N.N., Lebedev, E.A., Ponomarenko, A.G., Rautian, A.S., 1995. Climate belts of the MidCretaceous time. Stratigraphy and Geological Correlation 3, 241-260.

Cohen, K.M., Finney, S., Gibbard, P.L., 2013. International Chronostratigraphic Chart v 2013/01: International Commission on Stratigraphy. In www.stratigraphy.org (last
accessed in August 2013). Daghlian, P., Person, C.P., 1977. The cuticular anatomy of Frenelopsis varians from the Lower Cretaceous of central Texas. American Journal of Botany 64, 564-569.

Deng, S., Yang, X., Lu, Y., 2005. Pseudofrenelopsis (Cheirolepidiaceae) from the Lower Cretaceous of Jiuquan, Gansu, northwester China. Acta Palaeontologica Sinica
$44,505-516$. Doludenko, M.P., 1978. The genus Frenelopsis (Coniferales) and its ocurrence in the Cretaceous of U.S.R.R. Paleontological Journal 3, 107-121. Hay, W.W., Floegel, S., 2012. New thoughts about the Cretaceous climate and oceans.
Earth-Science Reviews 115, 262-172. Heimhofer, U., Ariztegui, D., Lenniger, M., Hesselbo, S. P., Martill, D.M., Rios Netto, A. M., 2009. Deciphering the depositional environment of the laminated Crato fossil
beds (early Cretaceous, Araripe Basin, Northestern Brazil). 694. 
Heimhofer, U., Martill, D.M., 2007. The sedimentology and depositional environment of the Crato Formation. In: Martill, D. M., Bechly, G. \& Loveridge, R. F. (eds). The Crato Fossil Beds of Brazil. Window into an Ancient World. Cambridge University Press, Cambridge, pp. 44-62.

Hlustik, A., 1988. Pseudofrenelopsis parceramosa (Fontaine) Watson from the Lower Cretaceous of Moravia, Czechoslovakia. Palaeontographica B 210, 1-8.

Kunzmann, L., Mohr, B., Bernardes-De-Oliveira, M.E.C., Wilde, V., 2006.

Gymnosperms from the Lower Cretaceous Crato Formation (Brazil). II.

Cheirolepidiaceae. Fossil Record 9 (2), 213-225.

Lima, M.R., 1978. Palinologia da Formação Santana, Cretáceo do Nordeste do Brasil. (PhD Thesis) - Instituto de Geociências, Universidade de São Paulo, São Paulo, 362 p.

Martill, D.M., 2007. The geology of the Crato Formation. In: Martill, D. M., Bechly, G. \& Loveridge, R. F. (eds). The Crato Fossil Beds of Brazil. Window into an Ancient World. Cambridge University Press, Cambridge, pp. 8-24.

Martill, D. M., Loveridge, R. F. and Heimhofer, U., 2007. Halite pseudomorphs in the Crato Formation (Early Cretaceous, Late Aptian-Early Albian), Araripe Basin, northeast Brazil: further evidence for hypersalinity. Cretaceous Research 28, 613-620.

Mohr, B.A.R., Friis, E.M., 2000. Early Angiosperms from the Lower Cretaceous Crato Formation (Brazil), a preliminary report. International Journal of Plant Sciences 161, S155-S167.

Mohr, B.A.R., Schultka, S., Süss, H.. Bernardes-de-Oliveira, M.E.C., 2012. A new drought resistant gymnosperm taxon, Duartenia araripensis gen. nov. et sp. nov. (Cheirolepidiaceae?) from the Early Cretaceous of Northern Gondwana. Palaeontographica B, 1-25.

Moreno-Sánchez, M., Gómez Cruz, A. de J., Castillo González, H., 2007. Frenelopsis y Pseudofrenelopsis (Coniferales: Cheirolepidiaceae) en el Cretácico Temprano de Colombia. Boletín de Geología UIS 29 (2), 13-19.

Neumann, V.H., Borrego, A.G., Cabrera, L. Dino, R., 2003. Organic matter composition and distribution through the Aptian-Albian lacustrine sequences of the Araripe Basin, northeastern Brazil. International Journal of Coal Geology 54, 21-40.

Pocock, S.J., Jansonius, J., 1961. The pollen genus Classopollis Plfug, 1953. Micropaleontology 7, 439-449.

Pons, D., Berthou, P.Y., Campos D.A., 1990. Quelques observations sur la palynologie de l'Aptien Superieur et de l'Albien du Bassin d'Araripe (N.E. du Bresil). In: Atas do I simpósio sobre a Bacia do Araripe e Bacias Interiores do Nordeste, Crato, pp. 241-252. 
Ponte, F.C., Ponte-Filho, F.C., 1996. Evolução tectônica e classificação da Bacia do Araripe. In: Simpósio sobre o Cretáceo do Brasil, 4, 1996. Boletim de resumos do Simpósio sobre o Cretáceo do Brasil, 4, Rio Claro, UNESP/IGCE, pp. 123-133.

Reymanowna, M., Watson, J., 1976. The genus Frenelopsis Schenk and the type species Frenelopsis hoheneggeri (Ettingshausen) Schenk. Acta Palaeobotanica 17 (1), 17-26.

Reyre, Y., 1970. Stereoscan observations on the pollen genus Classopollis Pflug 1953. Palaeontology 13, 303-322.

Reyre, Y., 1973. Palynologie du Mesozoique Saharien. Memoires du Museum National d'Histoire Naturelle, Series C, Sciences et la Terre 27, 1-284.

Saiki, K., 1999. A new cheirolepidiaceous conifer from the Lower Cretaceous (Albian) of Hokkaido, Japan. Paleontological Research 3 (1), 29-35.

Srinivasan, V., 1995. Conifers from the Puddeldock locality (Potomac Group, Early Cretaceous) in eastern North America. Review of Palaeobotany and Palynology 89, 257-286.

Srivastava, S.K., 1976. The fossil pollen genus Classopollis. Lethaia 9, 437-457.

Sun, B., Dai, J., Wang, Y., Jia, H., Yan, D., Jiang, Z., 2011. Pseudofrenelopsis fossils from Cretaceous gypsum beds in Guixi, Jiangxi Province, China and their geological significance. Island Arc 20 (1), 43-56.

Traverse, A., 2004. Proposal to conserve the fossil pollen morphogeneric name Classopollis against Corollina and Circulina. Taxon 53 (3), 847-848.

Upchurch, G.R. JR., Doyle, J.A., 1981. Paleoecology of the conifers Frenelopsis and Pseudofrenelopsis (Cheirolepidiaceae) from the Cretaceous Potomac Group of Maryland and Virginia. In: Romans, R.C., ed. Geobotany II. NewYork, Plenum Press, pp. 167-202.

Vakhrameev, V.A., 1970. Range and palaeoecology of Mesozoic conifers, the Cheirolepidiaceae. Paleontological Journal 1, 12-25.

Vakhrameev, V.A., 1991. Jurassic and Cretaceous floras and climates of the Earth. Cambridge University Press, Cambridge, 318 p.

Van der Ham R.W.J.M, van Konijnenburg-van Cittert, J.H.A., Dortangs, R.W., Herngreen J., van der Burgh J., 2003. Brachyphyllum patens (Miquel) comb. nov. (Cheirolepidiaceae?): remarkable conifer foliage from the Maastrichtian type area (Late Cretaceous, NE Belgium, SE Netherlands). Review of Palaeobotany and Palynology 127, 77-97.

Watson, J., 1977. Some Lower Cretaceous conifers of the Cheirolepidiaceae from the U.S.A. and England. Palaeontology 20, 715-749. 
Watson, J., 1983. A new species of the conifer Frenelopsis from the Cretaceous of

Figure captions

Figure 3. Stratigraphic range of Pseudofrenelopsis species during the Early Cretaceous

Figure 1. Outcrop area of the Crato Formation (Martill, 2007) in the north of the Araripe Basin and location of the area with limestone quarries between the towns Nova Olinda and Santana do Cariri in northeastern Brazil.

Figure 2. Approximate geographic location of Pseudofrenelopsis species plotted on an Aptian paleogeographic and paleoclimatic map (Chumakov et al., 1995 in Hay and Floegel, 2012). Floristic regions after Vakhrameev (1991). Pseudofrenelopsis capillata spec. nov. appears as the southermost occurrence in the Equatorial Region Vakhrameev's and in the evaporitic belt within the arid zone (Chumakov et al. 1995) for the Aptian.

Watson, J., 1988. The Cheirolepidiaceae. In: Beck, C.B. (Ed.) Origin and evolution of gymnosperms., Columbia University Press, New York, pp. 382-447.

Watson, J., Alvin, K.L., 1976. Silicone rubber casts of silicified plants from the Cretaceous of Sudan. Palaeontology 19(4), 641-650.

Yang, X.J., Guignard, G., Trévenard, F., Wang, Y.D., Barale, G., 2009. Leaf cuticle ultrastructure of Pseudofrenelopsis dalatzensis (Chow et Tsao) Cao ex Zhou (Cheirolepidiaceae) from the Lower Cretaceous Dalazi Formation of Jilin, China. Review of Palaeobotany and Palynology 153, 8-18.

Zhou, Z., 1995. On some Cretaceous frenelopsids with a brief review of cheirolepidiaceous conifers in China. Review of Palaeobotany and Palynology 84, 419438.

635 of the genus. 
637 Table 1. Comparison of Pseudofrenelopsis species: Location, age and morphology of 638 vegetative remains.

640 Table 2. Comparison of Pseudofrenelopsi species: Epidermal features of adaxial and 641 abaxial cuticles

642

643 Table 1. Comparison of different species of Pseudofrenelopsis: Stomatal characteristics 644

645 PLATE I

646 1. General aspect of Pseudofrenelopsis capillata nov. sp.. Branched shoot with

647 helicoidal phyllotaxy. Specimen MB.Pb.2002/1344 (holotype). Scale bar $=2 \mathrm{~cm}$.

648 2. Shoot fragment with large internodes and leaves in $2 / 5$ helicoidal phyllotaxy.

649 Numbers 1-5, leaves of the same spiral. Specimen MB.Pb.2002/1344 (holotype). Scale 650 bar $=1 \mathrm{~cm}$.

651 3. Shoot fragment with short internodes and leaves in $2 / 5$ helicoidal phyllotaxy.

652 Numbers 1-5, leaves of the same spiral. Specimen MB.Pb.2002/1344 (holotype). Scale 653 bar $=1 \mathrm{~cm}$.

654 4. Detail of free tip ( $t$ ) of a leaf on a large internode. Specimen MB.Pb.2002/1344

655 (holotype). Scale bar $=1 \mathrm{~mm}$.

656 5. Detail of free tip ( $t$ ) of a leaf on a short internode. Specimen MB.Pb.2002/1344

657 (holotype). Scale bar $=1 \mathrm{~mm}$.

658 6. General aspect of Pseudofrenelopsis capillata nov. sp.. Branched shoot with

659 helicoidal phyllotaxy. Specimen UFRJ $\mathrm{Pb} 428 \mathrm{a}$. Scale bar $=4 \mathrm{~cm}$. 
660 7. Detail of internode with leaves (1) and stele (s) with $1 / 3$ of the total width of shoot.

661 Specimen UFRJ Pb 428a. Scale bar $=5 \mathrm{~mm}$.

662 8. General aspect of Pseudofrenelopsis capillata nov. sp. Non branched shoot with

663 preserved cuticles. Specimen GP/3E 9118. Scale bar $=2 \mathrm{~cm}$.

664

665

PLATE II

666

1. SEM image of apical region of a leaf, showing longitudinal ridges corresponding to

667

rows of stomata and hairs at apical edge. Specimen MB.Pb.2002/1344 (holotype). Scale

668 bar $=1 \mathrm{~mm}$.

669

2. SEM detail of straight hairs at the apical edge of a leaf. Specimen MB.Pb.2002/1344

670 (holotype). Scale bar $=100 \mu \mathrm{m}$.

671 3. SEM detail of curved hairs at the apical edge of a leaf. Specimen MB.Pb.2002/1344

672 (holotype). Scale bar $=100 \mu \mathrm{m}$.

673 4. Light microscopy image of outer abaxial cuticle with stomata arranged in uniseriate

674 rows and ordinary epidermal cells with rounded papillae. Specimen GP/3E 9118. Scale

$675 \quad$ bar $=100 \mu \mathrm{m}$.

676 5. SEM image of outer abaxial cuticle with stomata arranged in uniseriate rows and

677 rounded papillae of epidermal cells. Specimen MB.Pb.2002/1344 (holotype). Scale bar

$678=100 \mu \mathrm{m}$.

679 6. SEM image of inner abaxial cuticle showing circular stomatal complexes arranged in

680 uniseriate rows and elongated epidermal cells between rows and polygonal whitin them.

681 Stomatal abertures oriented mostly oblique. Specimen MB.Pb.2002/1344 (holotype).

682 Scale bar $=100 \mu \mathrm{m}$. 
683 7. Light microscopy image of outer abaxial cuticle with two adjacent stomatal

684 complexes, subsidiary cells with papillae. Specimen GP/3E 9118. Scale bar $=50 \mu \mathrm{m}$.

686 PLATE III

687 1. SEM image of inner abaxial cuticle with circular stomatal complexes and

688 surrounding epidermal cells. Stomatal complex with five subsidiary cells (sc) and guard

689 cells (gc) with ledges (arrow). Anticlinal walls of epidermal cells thicker than those of

690 subsidiary cells. Specimen MB.Pb.2002/1344 (holotype). Scale bar $=20 \mu \mathrm{m}$.

691 2. SEM image of outer abaxial cuticle showing stomatal aberture with sunken guard

692 cells and papillae protruding from subsidiary cells closing the aberture. Specimen

693 MB.Pb.2002/1344 (holotype). Scale bar $=20 \mu \mathrm{m}$.

694 3. SEM image of outer abaxial cuticle showing stomatal aperture closed by papillae

695 protruding from subsidiary cells. Rounded papillae at cuticle surface. Specimen

696 MB.Pb.2002/1344 (holotype). Scale bar $=20 \mu \mathrm{m}$.

697 4. SEM image of inner abaxial cuticle showing circular stomatal complexes in rows and

698 elongated epidermal cells between the rows and polygonal shape within the stomatal

699 complexes. Stomatal abertures oriented obliquely to the rows. Specimen

700 MB.Pb.2002/1344 (holotype). Scale bar $=60 \mu \mathrm{m}$.

701 5. SEM image of inner abaxial cuticle in the basal area of the leaf with circular stomatal

702 complexes arranged in rows. Towards the base of the leaf (lower part of the picture),

703 stomata frequency lower and more spaced, epidermal cells within the stomata rows

704 more elongated if compared with those of the middle part of the leaf. Specimen

705 MB.Pb.2002/1344 (holotype). Scale bar $=100 \mu \mathrm{m}$. 
706 6. SEM image of abaxial cuticle in cross section. Cuticle thickness is $16 \mu \mathrm{m}$. Specimen

707 MB.Pb.2002/1344 (holotype). Scale bar $=20 \mu \mathrm{m}$.

708

709 PLATE IV

710 1. Light microscopy image of outer abaxial cuticle with an isolated stoma (arrow) and

711 hair coverage of epidermal cells. Specimen GP/3E 9118. Scale bar $=100 \mu \mathrm{m}$.

712 2. Light microscopy image of outer abaxial cuticle showing long hairs on periclinal

713 walls of epidermal cells. Specimen GP/3E 9118. Scale bar $=100 \mu \mathrm{m}$.

714 3. SEM image of stem with helicoidal thickenings and uniseriate areolate pits in

715 tracheids. Specimen UFRJ Pb 428a. Scale bar $=10 \mu \mathrm{m}$.

716 4. SEM image of stem, cross fields with cupressoid type pitting. Specimen UFRJ Pb

717 428a. Scale bar $=10 \mu \mathrm{m}$. 
Figure 1

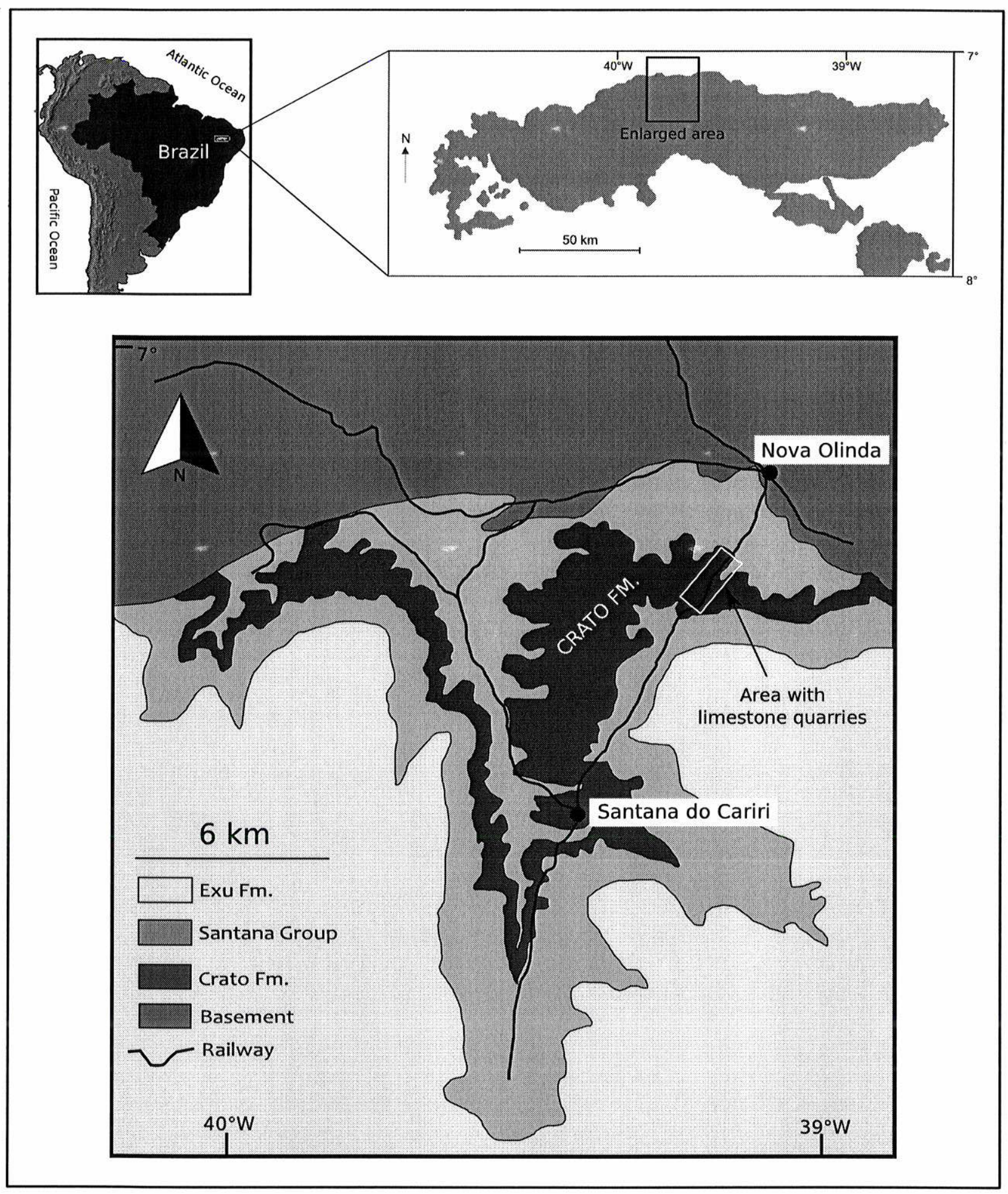


Figure 3

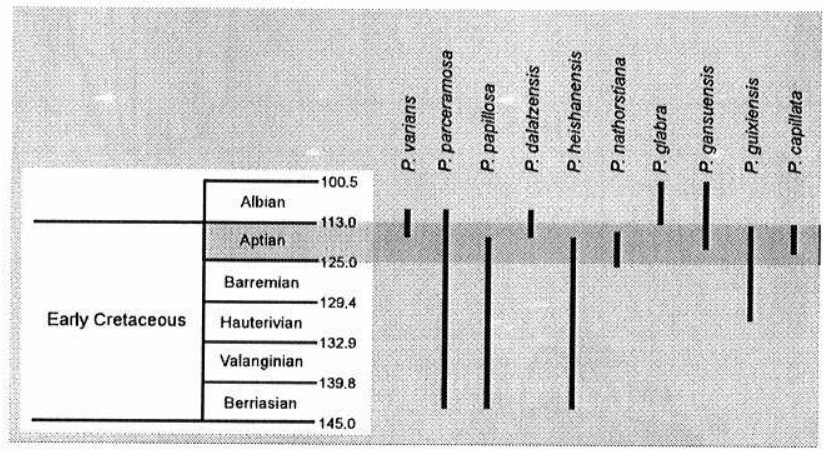




\section{Table 1}

Click here to download Table: Table1.pdf

\begin{tabular}{|c|c|c|c|c|c|c|c|c|}
\hline & Location & Age & Branching & Internode length & Internode width & Suture in leaves & $\begin{array}{l}\text { Maximum } \\
\text { length of free } \\
\text { tip in leaves }\end{array}$ & References \\
\hline P. varians & USA & Aptian-Albian & Sparse & $1.5-17 \mathrm{~mm}$ & $3-7 \mathrm{~mm}$ & None & $1.5 \mathrm{~mm}$ & Watson, 1977 \\
\hline P. parceramosa & $\begin{array}{l}\text { USA, England, } \\
\text { Portugal, Krakovia, } \\
\text { Moravia, Sudan }\end{array}$ & $\begin{array}{l}\text { Berriasian- } \\
\text { Aptian }\end{array}$ & Sparse & $1-11 \mathrm{~mm}$ & $2-7.5 \mathrm{~mm}$ & $\begin{array}{l}\text { Suture in some } \\
\text { open forms }\end{array}$ & $2 \mathrm{~mm}$ & $\begin{array}{l}\text { Reymanówna \& Watson, } \\
\text { 1976; Watson \& Alvin, 1976; } \\
\text { Alvin, 1977; Watson, 1977, } \\
\text { 1983; Hlustik, 1988; } \\
\text { Axsmith, 2006 }\end{array}$ \\
\hline P. papillosa & China & $\begin{array}{l}\text { Berriasian- } \\
\text { Aptian }\end{array}$ & Sparse & 5-11 mm & $3-7.5 \mathrm{~mm}$ & None & $1.5 \mathrm{~mm}$ & Zhou, 1995 \\
\hline P. dalatzensis & China & Aptian-Albian & $\begin{array}{l}\text { Presumed to be } \\
\text { sparse }\end{array}$ & $5.5-10 \mathrm{~mm}$ & $3-6.5 \mathrm{~mm}$ & None & $2 \mathrm{~mm}$ & $\begin{array}{l}\text { Zhou, 1995; Yang et al., } \\
2009\end{array}$ \\
\hline P. heishanensis & China & $\begin{array}{l}\text { Berriasian- } \\
\text { Aptian }\end{array}$ & $\begin{array}{l}\text { Presumed to be } \\
\text { sparse }\end{array}$ & $5-6 \mathrm{~mm}$ & $2.5-4 \mathrm{~mm}$ & None & $2 \mathrm{~mm}$ & Zhou, 1995 \\
\hline P. nathorstiana & USA & Aptian & Not described & $1-2.9 \mathrm{~mm}$ & $1-2 \mathrm{~mm}$ & Yes & $1 \mathrm{~mm}$ & Srinivasan, 1995 \\
\hline P. glabra & China & Albian & Not described & $6-8 \mathrm{~mm}$ & $4 \mathrm{~mm}$ & None & $1.5 \mathrm{~mm}$ & Saiki, 1999 \\
\hline P. gansuensis & China & Aptian-Albian & Not described & 7-11 mm & $9 \mathrm{~mm}$ & Not described & $1.5 \mathrm{~mm}$ & Deng, et al. 2005 \\
\hline P. guixiensis & China & $\begin{array}{l}\text { Lower } \\
\text { Cretaceous }\end{array}$ & Not described & $5-9 \mathrm{~mm}$ & 4-8 mm & Not described & $2 \mathrm{~mm}$ & Sun, et al. 2011 \\
\hline P. capillata & Brazil & Late Aptian & Sparse & $3.5-9.5 \mathrm{~mm}$ & 4-8 mm & None & $2 \mathrm{~mm}$ & This work \\
\hline
\end{tabular}


Hairs in leaf

upper margin

Outer adaxial

cuticle

Inner adaxial

cuticle

Outer abaxia

cuticle

Inner abaxial cuticle

With hairs up to

$60 \mu \mathrm{m}$

Cells mostly equidimensional, thick anticlinal walls

Cells equidimensional inside and longate between stomatal rows, thick anticlinal walls

\section{P. papillos}

Hairs up to

$80 \mu \mathrm{m}$

With hairs

Cells with \pm distinct anticlinal walls

Cells with distinct anticlinal walls

With papillae

Anticlinal walls thin

Without hairs or papillae

Cells tetragonal, anticlinas walls thin

With hairs up to $200 \mu \mathrm{m}$

$145 \mu \mathrm{m}$

With hairs up to $65 \mu \mathrm{m}$

Hairs up to

$$
40 \mu \mathrm{m}
$$

Without hairs

Not described

Without hairs or

papillae

Without hairs or

papillae

Without hairs

Not described

With hairs up to

$30 \mu \mathrm{m}$

$30 \mu \mathrm{m}$

anticlinas walls thin

Cells elongated with thick anticlinal walls
Elongate cells between stomatal rows

Cells equidimensional inside and elongate between stomatal rows, thick anticlinal walls

Cells equidimensional inside and elongate between stomatal rows, thick anticlinal walls

Cells equidimensional inside and elongate between stomatal rows, thin anticlinal walls

Cells equidimensional inside and elongate between stomatal rows, thick anticlinal walls

Unknown

Cells equidimensional inside and elongate between stomatal rows, thick anticlinal walls

Cells equidimensional inside and elongate between stomatal rows, thick anticlinal walls
Thickness of

baxial cuticles in

Hypodermal

cells

internodes

Seen only in

open leaf-base Watson, 1977

50-110 $\mu \mathrm{m} \quad$ open leaf-base

cushions

Reymanówna \& Watson,

1976; Watson \& Alvin, 1976;

Well-developed Alvin, 1977: Watson, 1977,

and cutinized 1983; Hlustik, 1988;

Axsmith, 2006

$5-7.5 \mu \mathrm{m}$

Absent

Zhou, 1995

$5-25$, usually $7.5-10$ $\mu \mathrm{m}$

Absent

Zhou, 1995; Yang et al. 2009

3-5 $\mu \mathrm{m}$

Absent

Zhou, 1995

$10 \mu \mathrm{m}$

Absent

Srinivasan, 1995

$3 \mu \mathrm{m}$

Well cutinized

Saiki, 1999

\section{Not described}

Not described

Deng, et al. 2005

$6-9 \mu \mathrm{m}$

Absent

Sun, et al. 2011

$16 \mu \mathrm{m}$ 


\begin{tabular}{|c|c|c|c|c|c|c|c|}
\hline & $\begin{array}{l}\text { Stomatal arrangement in } \\
\text { internodes }\end{array}$ & $\begin{array}{l}\text { Stomatal rows } \\
\text { per } \mathrm{mm}\end{array}$ & $\begin{array}{l}\text { Diameter of } \\
\text { stomatal complex }\end{array}$ & $\begin{array}{l}\text { Number of } \\
\text { subsidiary cells }\end{array}$ & Subsidiary cells & $\begin{array}{l}\text { Top view of } \\
\text { stomatal pit }\end{array}$ & References \\
\hline$P$. varians & $\begin{array}{l}\text { Scattered in closed form, } \\
\text { rows in open form }\end{array}$ & $8-10$ & $70-100 \mu \mathrm{m}$ & $4-9$, usually $5-8$ & $\begin{array}{l}\text { With papillae overhanging } \\
\text { stomatal pit }\end{array}$ & Rounded with papillae & Watson, 1977 \\
\hline P. parceramosa & Well-defined rows & $6-10$ & $50-80 \mu \mathrm{m}$ & $4-7$, usually $5-6$ & $\begin{array}{l}\text { Without or with papillae } \\
\text { protruded to stomatal pit }\end{array}$ & Rounded with papillae & $\begin{array}{l}\text { Reymanówna \& Watson, } \\
\text { 1976; Watson \& Alvin, 1976; } \\
\text { Alvin, 1977; Watson, 1977, } \\
\text { 1983; Hlustik, 1988; } \\
\text { Axsmith, 2006 }\end{array}$ \\
\hline P. papillosa & $\begin{array}{l}\text { Longitudinal rows with } \\
\text { scattered stomata }\end{array}$ & 4-9 & $40-92.5 \mu \mathrm{m}$ & $4-8$, usually $5-7$ & $\begin{array}{l}\text { With papillae overhanging } \\
\text { stomatal pit }\end{array}$ & Rounded with papillae & Zhou, 1995 \\
\hline P. dalatzensis & Well-defined rows & $6-10$ & $55-95 \mu \mathrm{m}$ & $5-6$ & $\begin{array}{l}\text { With papillae overhanging } \\
\text { stomatal pit }\end{array}$ & Stellate & $\begin{array}{l}\text { Zhou, 1995; Yang et al., } \\
2009\end{array}$ \\
\hline P. heishanensis & Well-defined rows & $8-10$ & $62.5-100 \mu \mathrm{m}$ & $5-7$, usually $5-6$ & $\begin{array}{l}\text { With papillae overhanging } \\
\text { stomatal pit }\end{array}$ & Stellate & Zhou, 1995 \\
\hline P. nathorstiana & Mostly ill-defined rows & $11-12$ & $\begin{array}{l}50-73 \text { or } 54-62 \mu \mathrm{m} \\
\text { rarely } 103 \mu \mathrm{m}\end{array}$ & $4-7$, usually $5-6$ & With papillae & $\begin{array}{l}\text { Elliptical to rounded, } \\
\text { with papillae }\end{array}$ & Srinivasan, 1995 \\
\hline P. glabra & Well-defined rows & $7-9$ & $80-120 \mu \mathrm{m}$ & $6-8$ & $\begin{array}{l}\text { With papillae overhanging } \\
\text { stomatal pit }\end{array}$ & Rounded with papillae & Saiki, 1999 \\
\hline P. gansuensis & Well-defined rows & $7-8$ & $90-100 \mu \mathrm{m}$ & $6-9$, usually $6-7$ & Without papillae & Unknown & Deng, et al. 2005 \\
\hline P. guixiensis & Well-defined rows & $8-10$ & $50-80 \mu \mathrm{m}$ & $4-6$ & With papillae & Rounded with papillae & Sun, et al. 2011 \\
\hline P. capillata & Well-defined rows & $7-9$ & $66-91 \mu \mathrm{m}$ & $\begin{array}{l}\text { usually } 5 \\
\text { ocasionally } 6\end{array}$ & $\begin{array}{l}\text { With papillae protruded to } \\
\text { stomatal pit }\end{array}$ & $\begin{array}{l}\text { Elliptical to rounded } \\
\text { with papillae }\end{array}$ & This work \\
\hline
\end{tabular}


Plate I
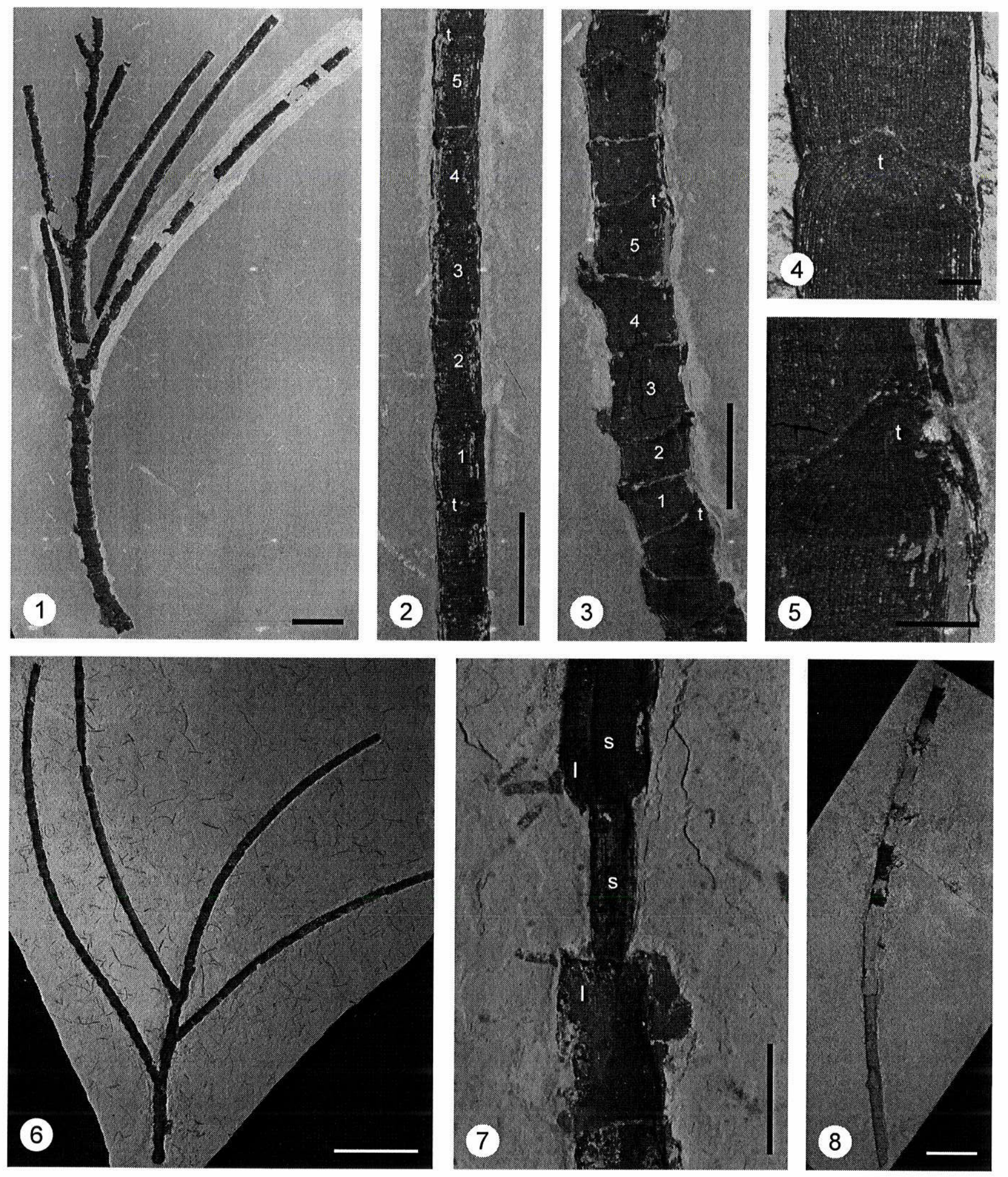



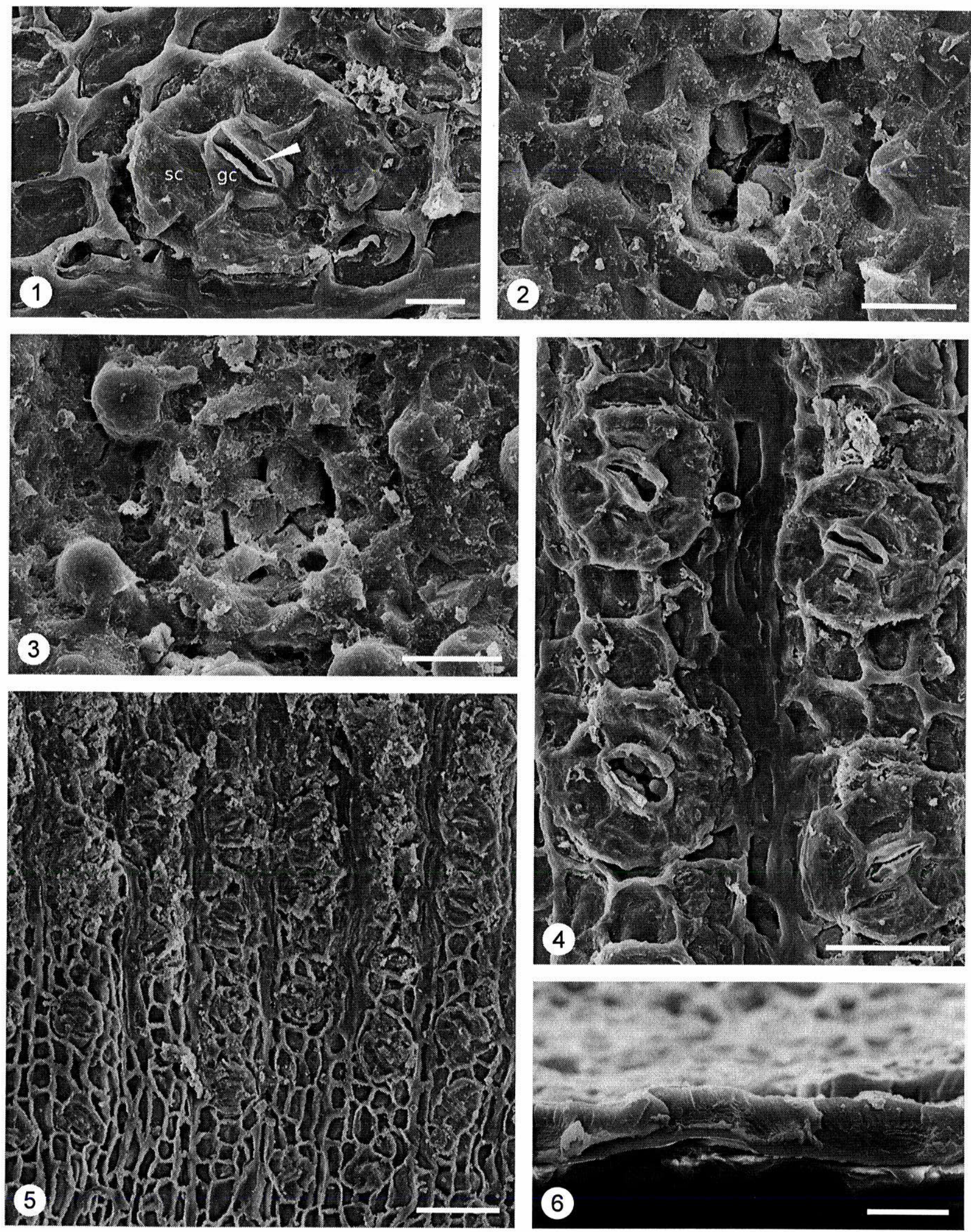

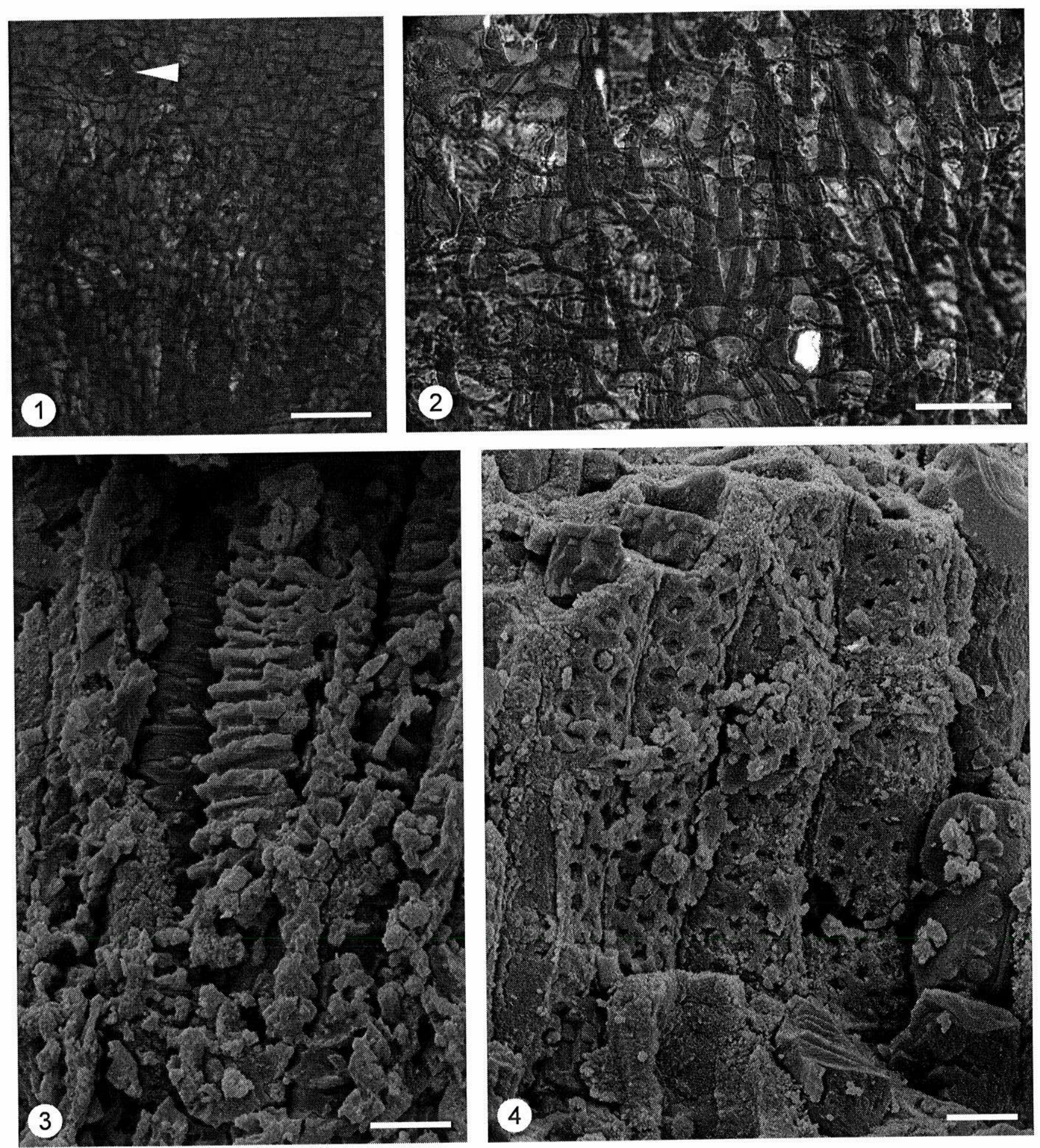
ANEXO 4 


\section{Submission Confirmation}

\section{Cretaceous Research <YCRES@elsevier.com>}

Para: psucerquia@gmail.com

Dear Mrs. Paula Sucerquia,

We have received your article "ARAUCARIAN BRACT-SCALE COMPLEXES FROM THE CRATO FORMATION, LOWER CRETACEOUS OF ARARIPE BASIN, BRAZIL" for consideration for publication in Cretaceous Research.

Your manuscript will be given a reference number once an editor has been assigned.

To track the status of your paper, please do the following:

1. Go to this URL: http://ees.elsevier.com/ycres/

2. Enter these login details:

Your username is: psucerquia@gmail.com

If you need to retrieve password details, please go to: http://ees.elsevier.com/ycres/automail_query.asp

3. Click [Author Login]

This takes you to the Author Main Menu.

4. Click [Submissions Being Processed]

Thank you for considering Cretaceous Research.

Kind regards,

Elsevier Editorial System

Cretaceous Research

Please note that the editorial process varies considerably from journal to journal. To view a sample editorial process, please click here:

http://ees.elsevier.com/eeshelp/sample_editorial_process.pdf

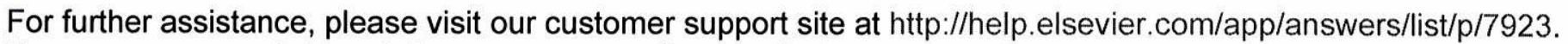
Here you can search for solutions on a range of topics, find answers to frequently asked questions and learn more about EES via interactive tutorials. You will also find our 24/7 support contact details should you need any further assistance from one of our customer support representatives. 
Elsevier Editorial System(tm) for Cretaceous Research

Manuscript Draft

Manuscript Number:

Title: ARAUCARIAN BRACT-SCALE COMPLEXES FROM THE CRATO FORMATION, LOWER CRETACEOUS OF ARARIPE BASIN, BRAZIL

Article Type: Full Length Original Article

Keywords: Early Cretaceous; Brazil; Crato Formation; Araucariaceae; bract-scale complex

Corresponding Author: Mrs. Paula Sucerquia,

Corresponding Author's Institution: Universidade de São Paulo

First Author: Paula Sucerquia

Order of Authors: Paula Sucerquia; Mary Elizabeth C Bernardes-de-Oliveira

Abstract: In spite of nowadays be restricted to the Southern hemisphere and with only three living genera, the Family Araucariaceae was widely distributed and diversified during the Mesozoic, mostly during Jurassic and Early Cretaceous, with a profusion of names for different plant organs summarized here. In the Crato Formation Flora of Araripe Basin, Northeastern Brazil, many of this morphogenera are found as leaves, male and female cones, pollen grains and bract-scale complexes of which a form are studied here. Based on an extensive revision and comparison of Cretaceous bract-scale complexes records worldwide, the species Araucaria duarteae is proposed and affinity to section Eutacta of the genus is established. 
ARAUCARIAN BRACT-SCALE COMPLEXES FROM THE CRATO FORMATION,

2 LOWER CRETACEOUS OF ARARIPE BASIN, BRAZIL

4 Paula Andrea Sucerquia1, Mary E.C. Bernardes-de-Oliveira1,2

6 1Universidade de São Paulo, Rua do Lago 562, Cidade Universitária, CEP 05508-

7 080, São Paulo, SP, Brasil. psucerquia@igc.usp.br

8 2Centro de Pós-Graduação e Pesquisa, Universidade Guarulhos, Av. Eng. Prestes

9 Maia 88, Centro, CEP 07011-080, Guarulhos, SP, Brazil

11 ABSTRACT

12 In spite of nowadays be restricted to the Southern hemisphere and with only three

13 living genera, the Family Araucariaceae was widely distributed and diversified during

14 the Mesozoic, mostly during Jurassic and Early Cretaceous, with a profusion of

15 names for different plant organs summarized here. In the Crato Formation Flora of

16 Araripe Basin, Northeastern Brazil, many of this morphogenera are found as leaves,

17 male and female cones, pollen grains and bract-scale complexes of which a form are

18 studied here. Based on an extensive revision and comparison of Cretaceous bract-

19 scale complexes records worldwide, the species Araucaria duarteae is proposed and

20 affinity to section Eutacta of the genus is established.

21 1.Introduction

22 During the Mesozoic, the conifer Family Araucariaceae was very diverse and widely

23 distributed in both hemispheres, especially during the Jurassic and Early Cretaceous 
24 (Stockey, 1982; Setoguchi et al., 1998; Kershaw \& Wagstaff, 2001; Kunzmann, 25 2007). However, current distribution and diversity is considered as relictual (Kershaw 26 \& Wagstaff, 2001) with 41 species (Farjon, 2001) and restricted to the southern 27 hemisphere. Living representatives of the family are grouped in three genera, 28 Araucaria, Agathis and Wollemia, which constitute a monophyletic group (Setoguchi 29 et al., 1998). The largest number of living species belongs to the genus Araucaria, as 30 it occurs in the fossil record. Araucaria genus is subdivided into the sections: Eutacta, 31 Araucaria, Bunya, and Intermedia (Stockey, 1982; Dettmann \& Clifford, 2005).

32 Yezonia section for fossil representatives of the family with Brachyphyllum-like foliage 33 and Eutacta-like seed cone (Oshawa et al., 1995). The oldest fossil representatives 34 of the Family Araucariaceae are of Eutacta and Bunya sections (Setoguchi et al., 35 1998).

36 Several fossils have been assigned to Araucariaceae, but some of them are 37 morphogenus with doubtful affinity to the family. These fossils are found as twigs, 38 isolated leaves, wood, cones, detached bract-scale complexes, seeds and pollen 39 grains. The generic names and brief discussion is showed by Kunzmann (2007) and 40 synthetized here in Table 1 with complementary information of Seward (1919) and 41 Stockey (1994).

42 In Araripe Basin, Crato Formation has abundant fossils related to the family 43 Araucariaceae, among which have been described: isolated leaves bract-scale 44 complexes assigned to the genus Araucarites (Duarte, 1989, 1993), Araucaria 45 female cone and Araucariostrobus male juvenile cone (Kunzmann et al., 2004). 46 Brachyphyllum leafy branches are also recorded (Duarte, 1985, 1989, 1993;

47 Kunzmann et al., 2004), but the assignment to the Family Araucariacea for fossils of 48 this genus has not been confirmed to date by cuticular or anatomical features. Fossil 
resin (amber) occurring within the cones and associated to the araucarian plant Pereira et al. (2006) analyzed the chemical composition of amber samples in Crato Formation and found compatibility of them to the family Araucariaceae.

Bract-scale complexes, ocurring in the Crato Formation, have a clear affinity to the family Araucariaceae, which can be established based on the characteristics described further on.

\section{Geological setting}

The Araripe Basin is located in the northeastern Brazil, extends for $8000 \mathrm{~km}^{2}$ and cover part of the Piauí, Pernambuco and Ceará States. Its origin and evolution are

59 related with the breaking of Western Gondwana (African and South American Plates)

and the subsequent implantation of the South Atlantic Ocean between them. Its

61 Paleozoic and Mesozoic sediments filling, lays over a Precambrian crystalline

basement, in four successive tectonic sequences (Ponte \& Ponte-Filho, 1996).

3 Mesozoic sediments correspond to the last three tectonic sequences: Pre-rift, Syn-rift 64 and Post-rift. The later, the Post-rift sequence (Aptian to Albian) is represented by the Santana Group, which includes the Rio da Batateira, Crato, Ipubi, Romualdo and Arajara Formations. The depositional environment of this sequence was fluviolacustrine to carbonatic lacustrine in its initial stage, passing to a shallow sea and

68 finally to a transitional environment (Neumann \& Cabrera, 1999). The Crato

69 Formation consists of six successive carbonatic sequences of laminated limestones

70 intercalated with claystones and fine grained sandstones, deposited in a lacustrine 71 system that had cover an area of $7500 \mathrm{~km}^{2}$ in its final stage. The paleolake was 72 supposed no more than 20 meters deep and halite pseudomorphs indicate a 73 hypersaline bottom waters in a meromictic lake (Neumann et al., 2002). 
74 Crato Formation is considered as one of the best-preserved and diverse Early

75 Cretaceous biota, framing as a Konservat Laggersttäte (Selden \& Nudds, 2005). The

76 age of the Crato Formation based on palynology is considered to be Meso-Alagoan

77 (Brazilian local stage) based in Cytheridea Ostracozone (NRT-011) and Sergipea

78 variverrucata Palynozone (P-270) (Arai et al., 2001). Meso-Alagoas local stage can

79 be correlated to the Late Aptian based on global microfloristic events (Arai et al.,

80 1989).

81

82 3.The Crato Flora

83 The Crato Formation flora contains a diverse micro and macrofossil assemblage

84 including pteridophytes, gymnosperms and angiosperms, the species richness is

85 relatively high with more than 80 macrofloral taxa (Mohr et al., 2007). It has been

86 described about 20 taxa of angiosperms (Duarte, 1985; Mohr \& Friis, 2000; Mohr \&

87 Rydin, 2002; Mohr \& Eklund, 2003; Mohr \& Bernardes-de-Oliveira, 2004; Mohr et al., 88 2006, 2009,; Coiffard et al., 2013), but gymnosperms are the most abundant group,

89 palynologically they are $70 \%$ against $30 \%$ of the remaining groups including

90 angiosperms. Gnetales and conifer microfossils and macrofossils constitute the most

91 distinct component of the flora (e.g. Lima, 1978, 1980; Duarte, 1985, 1989, 1993;

92 Rydin et al., 2003; Kunzmann et al., 2004, 2006, 2009, 2011; Mohr et al., 2004,

93 2009). The macrofloral assemblage contains both, isolated and organic connected

94 plant remains. In spite of that fossils in organic conection are more informative to

95 paleobotanic studies, detached organs could give data about taxonomic diversity and

96 on particular features of some species. The abundance, diversity and preservation of

97 detached bract-scale complexes in Crato Formation flora, justify their study. 
4.Material and Methods

The specimens were recovered from light yellow to grayish brown laminated limestones from Crato Formation; presumably from quarries between the towns of Santana do Cariri and Nova Olinda.

The studied material consists of 19 detached bract-scale complexes, stored at the repository collections of three institutions in Brazil: scientific collections of Laboratorio de Paleontologia Sistemática Instituto de Geociências (Universidade de São Paulo), Departamento de Geologia - Instituto de Geociências (Universidade Federal do Rio 107 do Janeiro) and the Geology and Paleontology Department of the Museu Nacional 108 (Universidade Federal do Rio do Janeiro).

109 The bract-scale complexes are preserved as three-dimensional casts of iron oxides 110 and rarely, casts of pyrite and as impressions. Epidermic and anatomic features are 111 badly observed in most of the specimens.

112 The fossils were studied under stereomicroscope with magnifications from 8 to 200 $113 \mathrm{X}$. Measures were obtained directly from the fossils or on drafts made under camera 114 lucida.

115 5.Systematics

116 Kingdom Plantae

117 Division Tracheophyte

118 Class Gymnospermopsida

119 Order Coniferales Jussieau

20 Family Araucariaceae

121 Genus Araucaria

122 Araucaria duarteae nov. sp.

123 Synonim: 
124 Araucarites vulcanoi pars Duarte, 1989, pp. 223-225, PI. III, fig. 3 non PI. III, fig. 4 125 Holotype: GP/3E 9098

126 Repository: Laboratório de Paleontologia Sistemática of the Instituto de Geociências, 127 Universidade de São Paulo.

128 Type locality: Laminated limestone quarries between the towns Nova Olinda and 129 Santana do Cariri, State of Ceará, Brazil.

130 Stratigraphic horizon: Crato Formation

131 Age: Late Aptian

132 Etimology: Derived from Lélia Duarte, brazilian paleobotanist who worked in Crato 133 Formation Flora

134 Specific diagnosis: Trapezoid shaped bract-scale complex with 14-20 mm length and $13511-19 \mathrm{~mm}$ width close to the apex. Single obovate seed with sinuous fibers in 136 surface. Wings with up to $4 \mathrm{~mm}$ width an longitudinal fibers. Apex thickened, curved 137 upwards with rows of stomata.

138 Paratypes: GP/3E 9088, GP/3E 9110a-b, GP/3E 9108, GP/3E 9109, GP/3E 9114, 139 GP/3E 9120, GP/3E 9381, GP/3E 9382 (Laboratório de Paleontologia Sistemática 140 of the Instituto de Geociências/USP) UFRJ 375 Pb, UFRJ 379 Pb, UFRJ 652 Pb, 141 UFRJ 856 Pb (Departamento de Geologia - Instituto de Geociências/UFRJ), MN $1423275 \mathrm{~Pb}, \mathrm{MN} 005 \mathrm{~Pb}, \mathrm{MN} 008 \mathrm{~Pb}, \mathrm{MN} 009 \mathrm{~Pb}$ (Departamento de Geologia e 143 Paleontologia do Museu Nacional/UFRJ).

144 Description: Detached bract-scale complexes of trapezoid shape measuring 145 approximately $14-20 \mathrm{~mm}$ length and $11-19 \mathrm{~mm}$ of maximum width in apex, narrowing 146 towards the base, reaching a minimum $4-7 \mathrm{~mm}$ width in proximal portion where is 147 possible to see two lobes, in each of the wings. Can be observed a single obovate 148 seed in central position, embedded in the complex tissue, measuring $7.5-10 \mathrm{~mm}$ of 
length and $5 \mathrm{~mm}$ of width. Seeds have sinuous fibers in the surface. Around the seed, is usually an hollow space, limited in both opposite sides by the wings, the wings are up to $4 \mathrm{~mm}$ width, with longitudinal straight fibers. In the apex there is a thickening, abaxial surface is curved upwards and some stomata in rows can be observed, the stomata have elipsoidal pits. An apophysis can not be differentiated in any of the specimens, but ligule is sometimes preserved.

\section{Discussion and Comparison}

The affinity of the bract-scale complexes to the Family Araucariaceae have been

158 established based on the existence of a single seed per scale and a ligule embedded 159 in bract (Archangelsky 1966).

160 The specimens studied in this work have the diagnostic characters of the bract-scale complex Araucarites vulcanoi in Duarte (1989, PI. III, fig. 3), but not the same species in Duarte (1993), although not all of them show the totality of characters, sometimes missing the seed, the ligule or the apophysis.

Araucarites is a morphogenus normally used to designate plant fragments from Permian to Neogene (mostly Mesozoic), which could suggest botanical affinity with the genus Araucaria, independently of the knowledge on the rest of the plant (Archangelsky, 1970). This genus have been used in the designation of araucariacean-like stems, leaves, cones and bract-scale complexes (Feistmantel, 1882; Seward \& Sahni, 1920; Archangelsky, 1970; Duarte, 1989, 1993). Although it was recommended to restrict the genus Araucarites, to complete female cones and isolated bract-scale complexes (Zijlstra \& Van Konijnenburg-van Cittert, 2000). Axsmith et al. (2008) promote the usage of the genus Araucarites only to very old or 173 poorly preserved representatives of the family Araucariaceae and never for 
174 specimens that can be assigned to a particular section of the genus Araucaria. They 175 were in agreement with Bose \& Maheshwari (1973) who propose the use of the 176 genus Araucaria instead of Araucarites for isolated bract-scale complexes when the 177 apical portion of ovuliferous scales is preserved.

178 Araucarites bract-scale complexes have been recorded in Mesozoic sediments of the 179 two hemispheres. Are common in the Jurassic of India (Feistmantel, 1876, 1877a, 180 1877b) and England (Kendall, 1949, 1952), the Lower Cretaceous of Argentina 181 (Archangelsky, 1966), Antarctica (Halle, 1913) and South Africa (Anderson and 182 Anderson, 1983) and middle Cretaceous in the United States (Berry, 1908, 1911). 183 The oldest fossil assigned to this genus is Araucarites delafondii from the Permian of 184 France (Seward, 1919). Specimens were also reported from the Triassic of Spain 185 (Ramis \& Pérez-López, 1996).

186 In Brazil, the Araucarites bract-scale complexes can be found in Rio Bonito 187 Formation, Permian (Bernardes-de-Oliveira, 1977), Santa Maria Formation, Upper 188 Triassic (Wilberger \& Dutra, 2005) and Crato Formation, Lower Cretaceous (Duarte, 189 1989, 1993; Kunzmann et al. 2004).

190 Fossils assigned to the genus Araucarites, were illustrated by Teixeira (1948) in the 191 Flora de Belas, Cretaceous of Portugal. He recognizes up to 3 different types of 192 bract-scale complexes and establishes the affinity to the Araucariaceae based on the 193 presence of only one seed. They differs from Araucaria duarteae in the length / width 194 ratio and the seed size, larger in the Crato Formation fossils, also the apophysis is 195 more elongated in Portuguese fossils.

196 In the Baqueró Group (Lower Cretaceous, Santa Cruz Province, Argentina) were 197 described two species of the genus Araucarites: A. baqueroensis and A. minimus 198 (Archangelsky, 1966). Those species are morphologically similar to Araucaria 
duarteae, Araucarites baqueroensis is also similar in size, but with maximum width a slightly larger due to the presence of more expanded wings, of about $8 \mathrm{~mm}$ from the

broader than seed. The ligule apex in the Argentine species is rounded, while in Araucaria duarteae is acute. Araucarites minimus has much smaller dimensions than those of Araucaria duarteae.

Araucarites cutchensis described for the Jurassic Flora of Kach (Cutch), India and the Flora of Jabalpur Group, Sripematur Group of the Upper Gondwana of Madras Coast and the Upper Jurassic Flora of Rajmahal Group. This species has diverse morphology (Feistmantel, 1876, 1877a, 1877b, 1879a, 1879b), and according to Seward \& Sahni (1920), it is not possible to define a set of characters to define a species with that morphological heterogeneity.

A. cutchensis share some characteristics with Araucaria duarteae, the seed shape is obovate, with a ridge along the entire longitudinal length. Shape and length/width ratio of some specimens presented by Feistmantel $(1876,1877 \mathrm{a}, 1879 \mathrm{~b})$ are also very similar to those of Araucaria duarteae.

Pant \& Srivastava (1968) studied cuticles in Araucarites cutchensis from Jabalpur Group in India, and compared them with those of living Araucaria columnaris. They argue a clear affinity with the living genus Araucaria and renamed the species as Araucaria cutchensis.

219 Another species described in India is Araucarites macropterus from the Flora of Sripematur Group, Upper Gondwana of Madras Coast and from the Upper Jurassic of the Rajmahal Group. This species, in contrast with Araucaria cutchensis. and $A$. duarteae, have highly developed membranous wings, similar to the South African species Araucaria rogersii and Araucaria mkuziensis (Anderson \& Anderson, 1983). 
224 Araucarian-like bract-scale complexes are also found in the Jurassic of Yorkshire in

England. The species Araucarites phillipsi appears in Kendall (1949) with several specimens of wedge shape and variable size, but according to the author all the specimens are uniform in shape and cellular structure. As in Araucaria duarteae a small apophysis and the ligule are visible. In the same unit, Kendall (1952) described A. estonensis as cone-scales not sharing many features with other Araucarites species, later recombined in Hirmeriella estonensis by having more affinity with the family Cheirolepidiaceae (Cornet \& McDonald, 1995).

In the Atlantic Coastal Plain of the United States, Berry (1908) described some araucarian fossils including isolated bract-scale complexes from the Big Bend and Parker Landing localities, Middle Cretaceous from North Carolina. He designated them as Araucaria jeffreyi, and considered similar to A. duarteae, only differing in the presence of a much larger apophysis resembling specimens of Araucarites cutchensis from India.

Berry (1911) described for the Patapsco Formation of the Potomac Group (Barremian-Aptian) of the State of Maryland (USA), two species of isolated bractscale complexes of the genus Araucarites: A. aquiensis and A. patapscoensis. These species do not clearly suggest, to have had only one seed. Rather, in the picture of A. patapscoensis, in Berry (1911, PI, LXXVII, Fig. 5), the scale seems to carry four seeds, suggesting an affinity to Family Cheirolepidiaceae.

Other Araucarites species, occurring in the United States, are Araucarites wyomingensis and Araucarites cuneatus of Lakota Formation in the region of the Black Hills (Upper Cretaceous), are smaller than those described by Berry (1911). Dammara cliffwoodensis and Dammara borealis, Upper Cretaceous of the east coast of the United States (Berry, 1910, 1911), suggest affinity to the genus Agathis. Bract- 

6

scale complexes of Araucarites type also occur in the Jurassic of Utah (Wilkens et al., 2005).

The intraspecific morphological diversity shown by Feistmantel $(1876,1877 \mathrm{a}, 1877 \mathrm{~b}$, 1879th) and Kendall (1949), reveal the difficulty to define useful features in the delimitation of species within the genus Araucarites. Variations in size and shape are found in living bract-scale complexes of the same species and even the same cone. This morphological heterogeneity also occurs between specimens identified as Araucaria duarteae, whose specific characterization is also difficult to define.

The affinity of some Araucarites bract-scale complexes with the genus Araucaria is discussed by Cantrill \& Falcon-Lang (2001). In their analysis of specimens from Alexander Island, Antarctica, they concluded that one of their described species, Araucarites wollemiaformis, would have more affinity with the living monospecific genus Wollemia, given the absence of the seed and ovuliferous scale, which have been shed from the cone when reached the maturity as also occurs in Agathis, contrasting with Araucaria bract-scale complexes (scale + ovuliferous scale + seed) fully detached from mature cones. According to Chambers et al. (1998), Araucaria bract -scale complexes can be found without the ovuliferous scale, but fused bract and seed in maturity, is a typical feature of bract-scale complexes of the genus Araucaria.

Comparing Araucaria duarteae with Araucarites wollemiaformis, some differences can be appointed: in the latter no seed can be observed and the entire complex is of obovate shape, leght/width ratio is higher in Araucarites wollemiaformis and their apophysis is longer than those in Araucaria duarteae.

The other species described by Cantrill \& Falcon-Lang (2001) for the Antarctic, Araucarites citadelbastionensis has similar characteristics to bract -scale complexes 
274 of Araucaria, as in Araucarites duarteae, has a short apophysis, but differs in the

2275

4

apex, rounded in the Antarctic species and straight in the Crato Formation species.

The Crato Formation bract-scale complexes studied here are related to

Araucariaceae as stated above, and are morphologically similar to bract-scale complexes of the section Eutacta following the taxonomic criteria used to place the Jurassic Holyoke Araucaria (Axsmith et al. 2008) within the same section. Early cretaceous bract-scale complexes related to this section also are known, Araucarites baqueroensis and Araucarites minimus from the Baqueró Group, Argentina (Del 282 Fueyo \& Archangelsky, 2002) and Araucaria cutchensis from India (Stockey, 1994). 283 All were previously compared to Araucaria duarteae.

284 7.Conclusions

285 The species Araucarites vulcanoi not constitute a valid name since in the definition of 286 the species two holotypes were allocated: a bract-scale complex and a leaf, 287 associated but not in organic connection. Also, the holotypes for Araucarites vulcanoi seem to be lost from their original repository. Based on the above, bract-scale complexes of the Crato Formation, Early Cretaceous of Araripe Basin, Brazil received 290 a new specific designation indicating a single holotype to fit in taxonomic rules.

291 The good quality of preservation, allow us to identify the structures of the bract-scale 292 complex makes possible their classification in the genus Araucaria and section 293 Eutacta.

294 Acknowledgments

295 The authors would like to acknowledge the collaboration of Dr. Ismar de Souza 296 Carvalho (Instituto de Geociências, Universidade Federal de Rio de Janeiro) for the 297 Ioan of the specimens. Thanks also to Dr. Marcelo de Araujo Carvalho (Museu 298 Nacional of the Universidade Federal de Rio de Janeiro) also for loan of specimens. 
Also want to thanks to Ivone Cardoso (Laboratório de Paleontologia Sistemática of the Instituto de Geociências, Universidade de São Paulo) for the access to scientific collection. The first author would also like to acknowledge the financial support as scholarship and research fund provided by the Fundação de Amparo a Pesquisa do Estado de São Paulo (FAPESP Proccess 2008/02884-5).

References

Anderson, J.M., Anderson, H.M., 1983. Palaeoflora of southern Africa. Molteno Formation (Triassic). Part 1. Introduction. Part 2. Dicroidium. Volume 1. A.A. Balkema, Rotterdam, 567 p.

Arai, M., Coimba, J.C., Silava-Telles, A.C., 2001. Síntese bioestratigrafica da Bacia do Araripe (Nordeste do Brasil). In: Simpósio sobre a Bacia do Araripe e Bacias Interiores do Nordeste, I, Crato, 1990. Comunicações do I e II Simpósio sobre a Bacia do Araripe e Bacias Interiores do Nordeste, Crato, p. 109-118. Archangelsky, S., 1966. New Gymnosperm from Ticó, Santa Cruz Province, Argentina. British Museum (Natural History) Bulletin of Geology 13, 259-295. Archangelsky, S., 1970. Fundamentos de Paleobotánica. Serie Técnica y Didáctica 10. Universidad Nacional de La Plata, La Plata, Argentina, 347 p.

Axsmith B.J., Escapa, I.H., Huber, P., 2008. An araucarian conifer bract-scale complex from the Lower Jurassic of Massachusetts: implications for estimating phylogenetic and stratigraphic congruence in the Araucariaceae. Palaeontologia Electrónica 11, 11.3.13A

Bernardes-de-Oliveira, M.E.C., 1977. Tafoflora Eogondvânica da Camada Irapuá, Formação Rio Bonito (Grupo Tubarão), SC. PhD thesis - Instituto de Geociências, Universidade de São Paulo, São Paulo, 301 p. 
324 Berry, E.W., 1908. Some araucarian remains from the Atlantic coastal plain. Bulletin

325 of the Torrey Botanical Club 35, 244-260.

326 Berry, E.W., 1910. Contributions to the Mesozoic flora of the Atlantic coastal plain VNorth Carolina. Bulletin of the Torrey Botanical Club 37, 181-200.

Berry, E.W., 1911. Contributions to the Mesozoic flora of the Atlantic coastal plain VII. Bulletin of the Torrey Botanical Club 38, 399-424.

Bose, M.N., Mahesshwaril, H.K., 1973. Some detached seed- scales belonging to Araucariaceae from the Mesozoic rocks of India. Geophytology 3, 205-214.

Bowe, L.M., Coat, G., De Pamphus, C.W., 2000. Phylogeny of seed plants based on all three genomic compartments: extant gymnosperms are monophyletic and Gnetales' closest relatives are conifers. Proceedings of the National Academy of Science 97, 4092-4097.

Cantrill, D.J., Falcon-Lang, H.J., 2001. Cretaceous (Late Albian) Coniferales of Alexander Island, Antarctica. 2. Foliage, reproductive structures and roots. Review of Palaeobotany and Palynology 115, 119-145.

Chambers, T.C. Drinnan, A. N., Mcloghlin, S., 1998. Some morphological features of Wollemi Pine (Wollemia nobilis: Araucariaceae) and their comparison to Cretaceous plant fossils. International Journal of Plant Science 159, 160-171.

Coiffard, C., Mohr, B.A.R., Bernardes-de-Oliveira, M.E.C., 2013. Jaguariba wiersemana gen. nov. et sp. nov., an Early Cretaceous member of crown group Nymphaeales (Nymphaeaceae) from northern Gondwana. Taxon 62, 141-151. Cornet, B., Mcdonald, N.G., 1995. A new cheirolepid conifer bearing flowers from the Early Jurassic of Connecticut, USA. In: Geological Society of America Convention, Cromwell, CT. Geological Society of America, Abstracts with Programs 27, p. 37. Del Fueyo, G.M., Archangelsky, A., 2002. Araucaria grandifolia Feruglio from the 
349 Lower Cretaceous of Patagonia, Argentina. Cretaceous Research 23, 265-277.

350 Dettmann, M., Clifford, T., 2005. Biogeography of Araucariaceae. In: History of the

351 Araucarian Forests, Australian Forest History Society, Queensland Museum, 9 p.

352 Available at: http://fennerschool-

353 associated.anu.edu.au/environhist/links/publications/anzfh/anzfh2dettmann\&clifford.p

354 df. Last month checked 08/2013.

355 Duarte, L., 1985. Vegetais fósseis da Chapada do Araripe, Brasil. Coletânea de

Trabalhos Paleontológicos. DNPM, Série Geologia, 27, 557-564.

Duarte, L., 1989. Remains of the Lower Cretaceous plants of North-East of Brazil. In: XI Congresso Brasileiro de Paleontologia, Curitiba, 1989. Anais do XI Congresso

Brasileiro de Paleontologia, Curitiba, I, 223-225.

Duarte, L., 1993. Restos de Araucariáceas da Formação Santana - Membro Crato (Aptiano), NE do Brasil. Anais da Academia Brasileira de Ciências 65, 357-362.

Farjon, A., 2001. World Checklist and Bibliography of Conifers, Second edition. The Royal Botanic Gardens, Kew, 316 pp.

Feistmantel, O., 1876. Jurassic (Oolitic) Flora of Kach. Memories of the Geological Survey of India, Palaeontologia Indica, Serie XI, 1, 1-80.

Feistmantel, O., 1877a. Jurassic (Liassic) Flora of the Rajmahal Group from Golapili (Near Ellore) South Godavari District. Memories of the Geological Survey of India, Palaeontologia Indica, Serie II, 3, 163-190.

Feistmantel, O., 1877b. Flora of the Jabalpur Group (Upper Gondwanas), in the SonNarbada Region. Memories of the Geological Survey of India, Palaeontologia Indica, Serie $\mathrm{XI}, 2,1-25$. 
Feistmantel, O., 1879a. The fossil flora of the Upper Gondwanas. Vol. I, 4. Outliers on the Madras coast. Memories of the Geological Survey of India, Palaeontologia Indica, Serie II, 191-224.

Feistmantel, O., 1879b. The fossil flora of the Gondwana system. Vol. I, The flora of the Talchir-Karharbari beds. Memories of the Geological Survey of India, Palaeontologia Indica, Serie XII, 3, 1-48.

Feistmantel, O., 1882. Fossil flora of Gondwana system in India-I. the fossil flora of the South Rewah Gondwana Basin. Memories of the Geological Survey of India, Palaeontologia Indica, Serie 12, 4 (1): 1-52

Halle, T.G., 1913. Some Mesozoic plant bearing deposits in Patagonia and Tierra del Fuego and their floras. Kunglinga Svenska Vetensakapakademien Handlingar 51, 158.

Kendall, M.W., 1949. A Jurassic member of the Araucariaceae. Annals of Botany 13, $151-161$.

Kendall, M.W., 1952. Some conifers from the Jurassic of England. Annals and

Magazine of Natural History Series 12, 583-594.

Kershaw, P., Wagstaff, B., 2001. The southern conifer family Araucariaceae: history, status, and value for palaeoenvironmental reconstruction. Annual Review Ecology and Systematics 32, 397-414.

Kunzmann, L., Mohr, B., Bernardes-de-Oliveira, M.E.C., 2004. Gymnosperms from the Lower Cretaceous Crato Formation (Brazil). I. Araucariaceae and Lindleycladus (incertae sedis). Mitteilung aus dem Museum für Naturkunde Berlin, Geowissenschaftliche Reihe 7, 155-174.

Kunzmann, L., 2007. Araucariaceae (Pinopsida): aspects in palaeobiogeography and palaeobiodiversity in the Mesozoic. Zoologisher Anzeiger 246, 257-277. 
Lima, M.R., 1978. Palinologia da Formação Santana (Cretáceo do Nordeste do

Brasil). Introdução geológica e descrição sistemática dos esporos de Subturma

Azonotriletes. Ameghiniana 15, 333-365.

400 Lima, M.R., 1980. Palinologia da Formação Santana (Cretaceo do Nordeste do 401 Brasil). 111. Descrição sistemática dos polens da Turma Plicates (Subturma

402 Costates). Ameghiniana 17, 15-47.

403 Martill, D.M., 2007. The geology of the Crato Formation. In: Martill, D. M., Bechly, G. 404 \& Loveridge, R. F. (eds). The Crato Fossil Beds of Brazil. Window into an Ancient 405 World. Cambridge University Press, Cambridge, pp. 8-24.

406 Martill, D.M., Loveridge, R.F., Andrade, J.A.F.G., Cardoso, A.H., 2005. An unusual 407 occurrence of amber in laminated limestones: The Crato Formation Lagerstätte 408 (Early Cretaceous) of Brazil. Paleontology 48, 1399-1408.

409 Mohr, B., Bernardes-de-Oliveira, M.E.C., Loveridge, R.F., 2007. The macrophyte 410 flora of the Crato Formation. In: Martill,D.M.; Bechly,G.; Loveridge, R.F.- The Crato 411 Fossil Beds of Brazil. Cambridge University Press, pp. 537-573.

412 Mohr, B., Bernardes-de-Oliveira, M.E.C, Barale, G., Ouaja, M., 2006.

413 Palaeogeographic distribution and ecology of Klitzschophyllites, and Early 414 Cretaceous angiosperm in Southern Laurasia and Northern Gondwana. Cretaceous 415 Research 27, 464-472.

416 Mohr, B., Bernardes-de-Oliveira, M.E.C., 2004. Endressinia brasiliana, a 417 Magnolialean angiosperm from the Lower Cretaceous Crato Formation (Brazil). 418 International Journal of Plant Sciences 165, 1121-1133.

419 Mohr, B., Bernardes-de-Oliveira, M.E.C., Taylor, D.W., 2009. Pluricarpellatia, a 420 nymphaealean angiosperm from the Lower Cretaceous of northern Gondwana (Crato 421 Formation, Brazil). Taxon 57, 1147-1158. 
422 Mohr, B., Eklund, H., 2003. Araripia florifera, a magnoliid angiosperm from the Lower

423 Cretaceous Crato Formation (Brazil). Review of Palaeobotany and Palynology 126, $424 \quad 279-292$.

425 Mohr., B., Rydin, C., 2002. Trifurcatia flabellata n. gen. n. sp., a putative

426 monocotyledon angiosperm from the Lower Cretaceous Crato Formation (Brazil).

427 Mitteilung aus dem Museum für Naturkunde Berlin, Geowissenschaftliche Reihe 5, $428 \quad 335-344$.

429 Neumann, V.H., Cabrera, L., 1999. Una nueva propuesta estratigráfica para la 430 tectonosecuencia post-rifte de la cuenca de Araripe, noreste de Brasil. In: Simpósio 431 Cretáceo Brasileiro, 5, Serra negra, 1999. Boletim de Resumos, UNESP, p. 279432285

433 Neumann, V.H., Cabrera, L., Mabesoone, J.M., Valença, L.M.M., Silva, A.L., 2002. 434 Ambiente sedimentar e facies da seqüência lacustre aptiana-albiana da bacia do 435 Araripe, NE do Brasil. In: $6^{\circ}$ Simpósio sobre o Cretáceo do Brasil e $2^{\circ}$ Simpósio 436 sobre el Cretácico de América del Sur, Rio Claro. Anais... Rio Claro, UNESP, p 3743751.

438 Ohsawa, T., Nishida, H., Nishida, M., 1995. Yezonia, a new section of Araucaria 439 (Araucariaceae) based on permineralized vegetative and reproductive organs of 440 A. vulgaris comb. nov. from the Upper Cretaceous of Hokkaido, Japan. Journal of 441 Plant Research 108, 25-39.

442 Pant, D.D., Srivastava, G.R., 1968. On the cuticular structure of Araucaria 443 (Araucarites) cutchensis (Feistmantel) comb. Nov from the Jabalpur Series, India. 444 Journal of the Linnean Society London Botany 61, 201-206.

445 Pereira, R., Carvalho, I.S., Azevedo, D.A., 2006. Afinidades paleobotânicas de 446 âmbares cretácicos das bacias do Amazonas, Araripe e Recôncavo. In: 7 Simpósio 
447 do Cretáceo do Brasil / 1 Simpósio do Terciário do Brasil, 2006, Serra Negra. Boletim

448 do: 7 Simpósio do Cretáceo do Brasil / 1 Simpósio do Terciário do Brasil, 2006,

449 Serra Negra, UNESP, p. 100.

450 Ponte, F.C., Ponte-Filho, F.C., 1996. Evolução tectônica e classificação da Bacia do

451 Araripe. In: Simpósio sobre o Cretáceo do Brasil, 4, 1996. Boletim... Rio Claro,

452 UNESP/IGCE. p. 123-133.

453 Ramis, C., Pérez-López, A., 1996. Megaflora hallada en el Trías de Facies

454 Germánica del sector central de la Cordillera Bética. Cuadernos de Geología Ibérica $45520,215-227$.

456 Rydin, C., Mohr, B., Friis, E.M., 2003. Cratonia cotyledon gen. et sp. nov. : a unique 457 Cretaceous seedling related to Welwitschia . Proceedings of the Royal Society 458 Biology Letters (Supplement) 270, S29-S32.

459 Selden, P.A., Nudds, J.R., 2005. Evolution of Fossil Ecosystems. Manson Publishing, 460 Ltd., London, $192 \mathrm{p}$.

461 Setoguchi H, Osawa Ta, Pintaud Jc, Jaffre T, VEILLON JM. 1998. Phylogenetic 462 relationships within Araucariaceae based on $\mathrm{RBCL}$ gene sequences. American 463 Journal of Botany $85,1507-1516$.

464 Seward, A.C., 1919. Fossil plants. IV. Ginkgoales, Coniferales, Gnetales. Cambridge 465 University Press, Cambridge. $543 \mathrm{p}$.

466 Seward, A.C., Sahni, B., 1920. Indian Gondwana Plants: a revision. Memories of the 467 Geological Survey of India - Paleontologia Indica 7, 1-40.

468 Stefanovic, S., Jager, M., Broutin, J., Masselot, M., 1998. Phylogenetic relationships 469 of conifers inferred from partial $28 \mathrm{~S}$ rRNA gene sequences. American Journal of 470 Botany $85,688-697$. 
471 Stockey, R.A., 1982. The Araucariaceae: an evolutionary perspective. Review of 472 Palaeobotany and Palynology 37, 133-154.

473 Stockey, R.A., 1994. Mesozoic Araucariaceae: morphology and systematic 474 relationships. Journal of Plant Research 107, 493-502.

475 Teixeira, C., 1948. Flora Mesozoica Portuguesa, I. Serviços Geológicos Portugal, 476 Lisbon, $119 \mathrm{pp}$.

477 Wilberger, T.P., Dutra, T.L., 2005. Estruturas reprodutivas do tipo Araucarites em 478 níveis do Triássico Superior da Bacia do Paraná no Rio Grande do Sul.

479 Paleontologia em Destaque 49, 21-22.

480 Wilkens, N.D., Farmer, J.D., Pigg, K., 2005. Exceptional paleobotanical remains 481 preserved in Navajo Sandstone interdune deposits near Moab, Utah. Salt Lake City 482 Annual Meeting. Geological Society of America Abstracts with Programs 37, p 527. 483 Ziljlstra, G., Van Konijnenburg-Van Cittert, H., 2000. Proposal to conserve the name 484 Araucarites C. Presl (Fossil Gymnospermae, Coniferales, Araucariaceae) against 485 Araucarites Endl. (Fossil Gymnospermae, Coniferales). Taxon 49, 279-280.

Figure 2. Specimens of Araucaria duarteae. A. GP/3E 9098 (Holotype) showing the trapezoidal shape, seed (s), wings (w) and ligule (I). B. GP/3E 9381 specimen detached from the matrix, where is possible to appreciate the threedimensional preservation of the seed (s), wings (w) are not entirely preserved and the apex 
496 surface has stomata in rows. C. Detail of GP/3E 9381 showing the apex with 497 stomatal rows. 
Figure 1

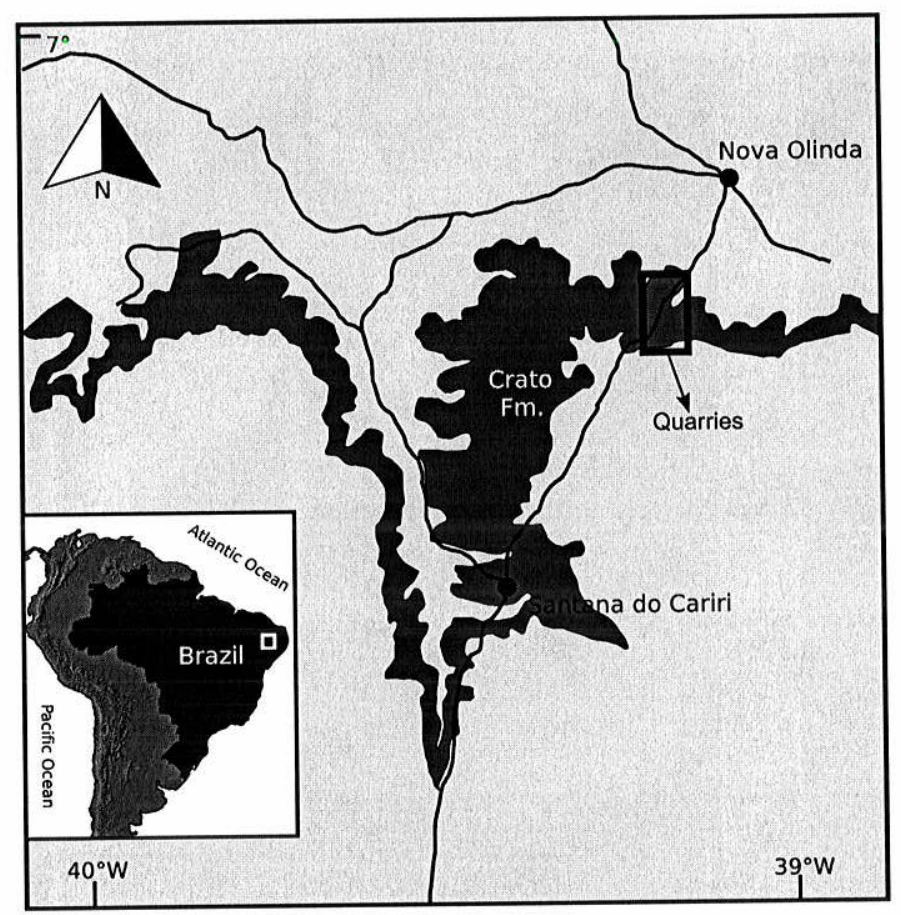



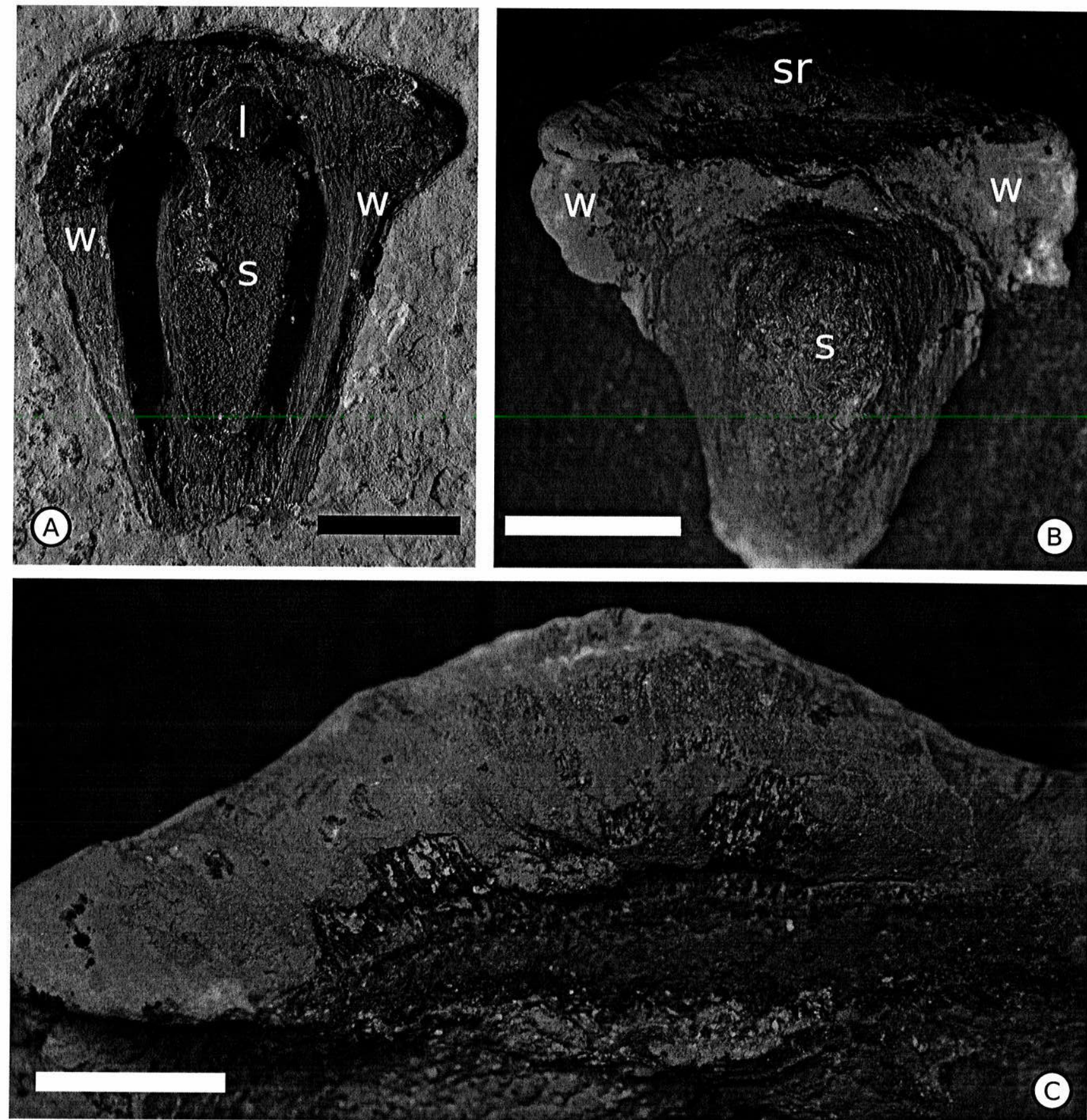
Araucaria

Araucarites

Brachyphyllum

Pagiophyllum

Araucariostrobus

Doliostrobus

Dammara

Dammarites

Dammarophyllum

Protodammara

$\begin{array}{cccccc} & \text { Female } & \text { Male } & \text { Cone } & & \text { Pollen } \\ \text { Leaves } & \text { cones } & \text { cones } & \text { scales } & \text { Wood } & \text { grains } \\ X & X & X & X & & \end{array}$

Agathis

Nageia

Araucarioides

Wairarapaia

Araucarioxylon

Dadoxylon

Agathoxylon

Dammaroxylon

Araucariacites

Balmeiopsis

Cyclusphaera

Dilwynites

Callialasporites

$x \quad x$

$X$

$X$

$X$

$\begin{array}{ll}x & x \\ x & x\end{array}$

$x$

$x$

$X$

$x$

$x$

$x$

$x$

$\mathrm{X}$

$x$

$x$

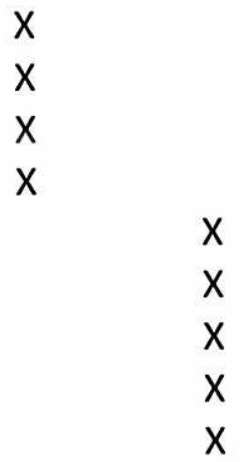

Generic names for morphogenus assigned to the Family Aracuariaceae (based on information in Seward, 1919; Stockey, 1994 and Kunzmann, 2007) 
ANEXO 5 


\section{INDICADORES PALEOCLIMÁTICOS NA PALEOFLORA DO CRATO, FINAL DO APTIANO DO GONDWANA NOROCIDENTAL}

\section{PALEOCLIMATIC INDICATORS IN THE CRATO PALEOFLORA, LATE APTIAN OF THE NORTH WESTERN GONDWANA}

Mary Elizabeth C. Bernardes-De-Oliveira ${ }^{1,2}$, Paula Andréa Sucerquia ${ }^{2}$, Barbara Mohr ${ }^{3}$, Rodolfo Dino ${ }^{4,5}$, Luzia Antonioli ${ }^{5}$ \& Maria Judite Garcia ${ }^{1}$

${ }^{1}$ Universidade de Guarulhos, CEPP/UnG, Praça Tereza Cristina 1, Centro, 07023-070 Guarulhos, SP, Brasil ${ }^{2}$ Universidade de São Paulo, Instituto de Geociências, Rua do Lago 562, Cidade Universitária, 05508-080 São Paulo, SP, Brasil ${ }^{3}$ Museum für Naturkunde der Humbolt-Universität, Department of Collections, Invalidenstr. 43, 10115, Berlin, Germany ${ }^{4}$ CENPES-Petrobras Avenida Horácio Macedo, 950. 20550-900 Ilha do Fundão, Rio de Janeiro, RJ, Brasil

5Universidade do Estado do Rio de Janeiro, IG, Rua São Francisco Xavier, 524, Maracanã, 20550-900 Rio de Janeiro, RJ, Brasil

E-mails: maryeliz@usp.br,psucerquia@gmail.com, barbara.mohr@mfn-berlin.de,dino@petrobras.com.br,antonioli@gmail.com,

mgarcia@ung.br

\section{RESUMO}

Durante o Eocretáceo, as temperaturas tropicais e polares foram altas havendo um gradual aquecimento, desde o limite Aptiano-Albiano até o Cenomaniano, com grande mudança na paleogeografia global decorrente da ruptura do Gondwana, mudanças nas correntes oceânicas e intensa orogenia. Esses eventos influíram nos padrões continentais de vento e chuva e nas concentrações de gases atmosféricos, resultando em mudanças paleoflorísticas. A bacia do Araripe esteve situada numa região quente, árida-evaporítica da zona equatorial tropical, onde chuvas ocorriam esporadicamente, segundo alguns autores, ou semiárida, em regime de monções, conforme outros. As plantas respondem as influências climáticas com adaptações morfoanatômicas como: feições epidérmicas e cuticulares, aquisições de papilas e espinhos, produção de resinas, redução na perda de água nas folhas, armazenamento de água em seus tecidos foliares e/ou caulinares. A paleoflora da Formação Crato era composta por licófitas, esfenófitas, filicófitas, pteridospermales, benetitales, coniferales, gnetales e gimnospermas incertae sedis, além de angiospermas. Suas presenças são comprovadas por macro e microfósseis. Analisando cada um de seus táxons, é possível detectar a presença de feições morfoadaptativas para climas semiáridos a áridos, provavelmente, sob regime de chuvas torrencial e esporádico.

Palavras-chave: Aptiano, Crato, paleoflora

\section{ABSTRACT}

During the Early Cretaceous, tropical and polar temperatures were high and there is a gradual warming since the Aptian-Albian boundary to the Cenomanian, with major change in global paleogeography resulting from the disruption of Gondwana, changes in ocean currents and intense orogeny. These events influenced the continental patterns of wind and rain and the concentration of atmospheric gases, resulting in paleofloristic changes. The Araripe Basin was located in a hot, arid evaporite-equatorial tropical zone, where rainfall occurred sporadically, according to some 
authors, or semiarid in the monsoon regime, as others. Plants respond to climatic influences with morpho-anatomical adaptations such as epidermal and cuticular features, acquisitions of papillae and spines, resin production, reducing water loss in leaves, water storage tissues in their leaves and / or stems. The paleoflora of the Crato Formation comprised lycophytes, sphenophytes, filicophytes, pteridospermales, benetitales, coniferales, gnetales and gymnosperms incertae sedis, and angiosperms. Their presence is evidenced by macro and microfossils. Analyzing each of its taxa, it is possible to detect the presence of morfoadaptatives features to semiarid to arid climates, probably, under a torrential and sporadic rains.

Keywords: Aptian, Crato, paleoflora

\section{INTRODUÇÃO}

As plantas são particularmente sensíveis às mudanças climáticas, principalmente pelo fato de serem organismos com mobilidade reduzida na escala de tempo de vida de cada indivíduo. Por isso, fitofósseis constituem bons indicadores paleoambientais, pois exibem adaptaçóes estruturais características dos habitats onde viveram. As típicas adaptações das plantas continentais aos climas, sob os quais elas vivem, são um resultado determinado, geralmente, por seu caráter sedentário (Chaloner \& McElwain, 1997).

Quando se volta atrás no tempo geológico, as plantas fósseis vão se tornando cada vez mais diferentes das atuais, até se encontrarem com maior frequência grupos sem representantes viventes. Apesar disso, caracteres morfológicos e anatômicos (espessura da epiderme, formato e quantidade de estômatos, forma e tamanho foliar, presença de anéis de crescimento em caules, entre outras), que aparecem como respostas a adaptações ambientais, podem ser observadas ao longo do tempo geológico e inclusive aparecerem repetidas vezes. São feições análogas, resultantes de influência paleoclimática ou ambiental, sem que haja obrigatoriamente relações filogenéticas entre as plantas que as possuem.

Durante o Eocretáceo (Berriasiano - Albiano 145 a 99 Ma, segundo Gradstein et al., 2012), ocorreram grandes mudanças climáticas que afetaram significativamente a vida nos continentes $\mathrm{e}$ oceanos (Keller, 2008). Muitas evidências mostram que as temperaturas e os níveis de $\mathrm{CO}_{2}$ atmosférico, em geral, durante o Cretáceo, foram mais elevados que os atuais (Frakes et al., 1992; Barron et al., 1993), as faixas climáticas eram mais similares com gradiente latitudinal reduzido (Barron, 1983; Sloan \& Barron, 1990; Valdes et al., 1996). Alguns modelos de circulação geral para o Cretáceo mostram aumentos de até $8^{\circ} \mathrm{C}$, nos fundos oceânicos, e valores até quatro vezes maiores de $\mathrm{CO}_{2}$ na atmosfera (Sellwood \& Valdes, 2006).

Muitas dessas mudanças são explicadas como resultado de uma intensa atividade vulcânica relacionada à formação de Grandes Províncias Ígneas (LIPs), tais como os derrames de basalto da província Paraná-Etendeka ( 139-130 Ma = Valangiano - Hauteriviano), bem como a formação dos plateaus de Ontong Java e Manihiki ( 130-126 Ma = Barremiano). Esses eventos alteraram profundamente a composição da atmosfera e dos oceanos, aumentando o teor de $\mathrm{SO}_{2} \mathrm{e} \mathrm{CO}_{2}$, causando um aquecimento global e levando aos Eventos Oceânicos Anóxicos (OAEs), causadores de extinções e/ou diversificações de vários grupos de organismos (Schlanger \& Jenkyns, 1976; Peat, 1997; Larson \& Erba, 1999; Premoli-Silva et al., 1999; Wignall, 2001; Kidder \& Worsley, 2010). 
No geral, a época eocretácea é considerada de temperaturas tropicais e polares altas e marcada por gradual aquecimento desde o limite Aptiano-Albiano (final do Eocretáceo $113 \mathrm{Ma}$ ) até o Cenomaniano (início do Neocretáceo $100 \mathrm{Ma}$ ).

O intervalo Aptiano- Albiano corresponde a uma época de grande mudança na paleogeografia global, com a ruptura do supercontinente Gondwana e a separação da América do Sul e África. Mudanças nos padrões gerais das correntes oceânicas e da circulação atmosférica, decorrentes de rearranjos das placas continentais e da atividade intensa de cinturões orogenéticos, influenciaram nos padrões continentais de vento e chuva e nas concentrações de gases atmosféricos, resultando em grandes mudanças florísticas sobre os continentes (Woodward \& Williams, 1987).

A Bacia do Araripe (Figura 1) esteve situada numa região quente, árida - evaporítica da zona Tropical Equatorial, onde chuvas ocorriam esporadicamente, segundo Chumakov (1995). Com base em anéis de crescimento, de lenhos fósseis provenientes da Formação Missão Velha (Neojurássico a Neocomiano da bacia), Pires (2008) concluiu que ali reinou um clima de altas temperaturas, com alternância cíclica entre períodos secos (invernos) e chuvosos (verão), num bioma de savana, típico do paleoclima juro-cretáceo.

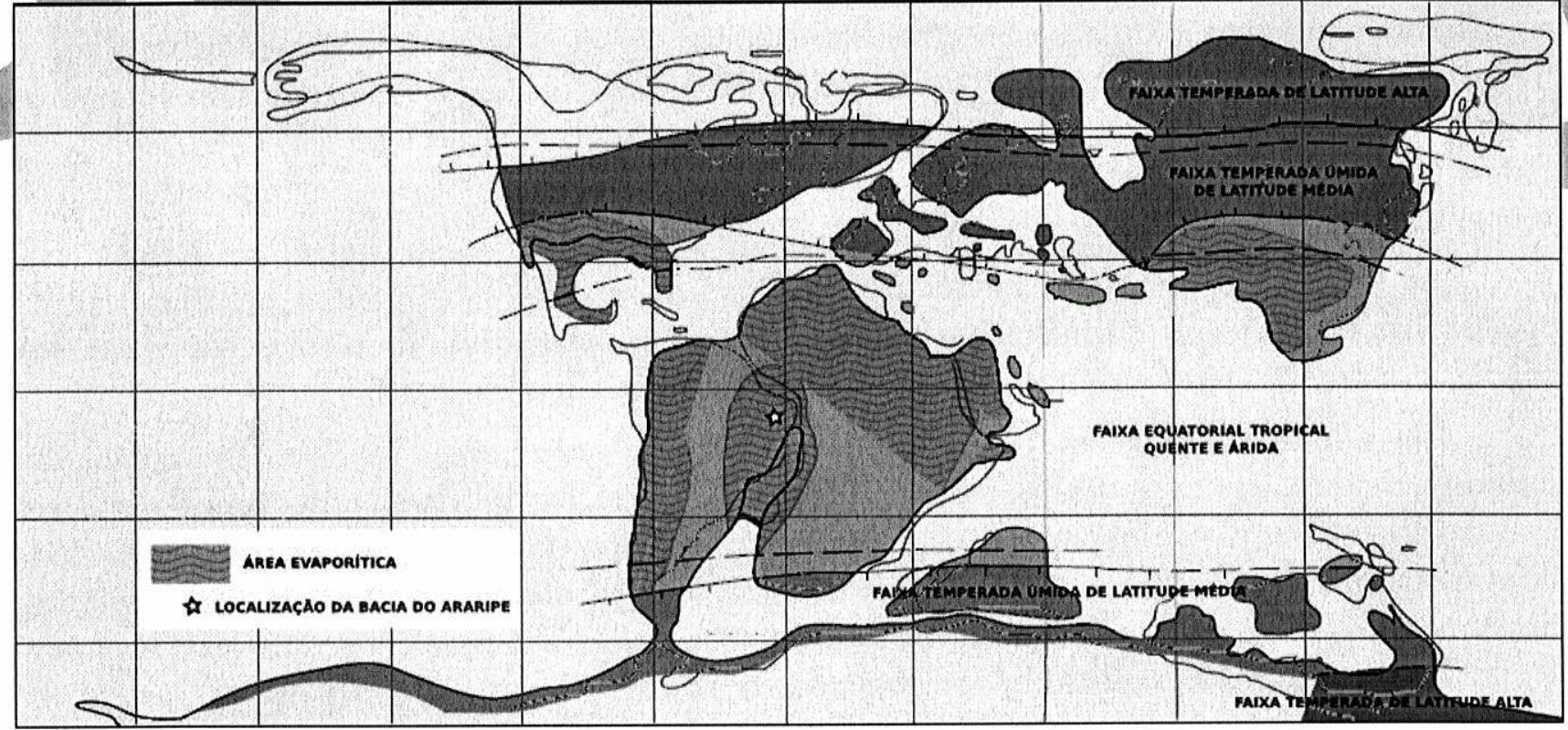

Figura 1. Localização da Bacia do Araripe na area evaporitica da faixa equatorial tropical quente e árida de Chumakov (1995) (Modificado de Hay \& Floegel, 2012).

A Formação Crato (Neoaptiano da bacia) é constituída de calcários micríticos laminados, com cerca de algumas dezenas de metros, dispostos em bancos descontínuos, contendo um variado e abundante registro fossilífero de plantas e animais, indicando ambiente continental lacustre, mas não completamente isolado de influência atmosférica oceânica (Neumann, 1999). Sobre os carbonatos, há camadas descontínuas de gipsita (Ipubi), associadas a folhelhos verdes e negros pirobetuminosos ricos em fósseis não marinhos, com até $30 \mathrm{~m}$ de espessura, cujas características evidenciam um paleoambiente costeiro de supramaré, em clima árido a semiárido. 
Com base em dados de circulação global para o Eocretáceo, Barron \& Moore (1994) propuseram para a região da Bacia do Araripe um clima tropical semiárido, em regime de monções, com precipitações máximas de 900 a $1.000 \mathrm{~mm}$ no verão e 0 a $90 \mathrm{~mm}$ no inverno, com uma relação precipitação evaporação ao redor de 1 e temperaturas médias muito elevadas e quase sem variação sazonal $\left(35^{\circ}\right.$ a $40^{\circ} \mathrm{C}$, no verão e $30^{\circ}$ a $35^{\circ}$, no inverno).

O paleolago do Crato é considerado de água doce em sua superfície marginal, mas com uma coluna de água estratificada quanto à salinidade, crescente para o fundo e à medida que a aridez sazonal aumentava, gradualmente, ao longo do tempo (Neumann, 1999; Selden \& Nudds, 2005; Assine, 2007).

Pretende-se aqui evidenciar como os macrofitofósseis e a palinoflora da Formação Crato comprovam esse paleoclima.

\section{INFLUÊNCIA CLIMÁTICA SOBRE AS PLANTAS}

O clima exerce o principal controle sobre a distribuição dos biomas em escala mundial. As temperaturas mínimas extremas e as taxas hidrológicas, isto é, a precipitação anual baixa, aliada à taxa de evaporação e de transpiração, efetivamente, determinam os limites de distribuição dos biomas do mundo. As variações de menor escala dentro da distribuição da vegetação são determinadas por fatores característicos, de menor influência no ambiente, tais como tipos de solo, atividade humana ou topografia (Woodward \& Williams, 1987).

As plantas respondem às influências climáticas com adaptaçôes morfoanatômicas: feições epidérmicas e cuticulares normalmente refletem estratégias adaptativas de plantas que vivem sob condições extremas como xerófitas, higrófitas e halófitas (Moisan et al., 2011).

Em climas tropicais áridos, as plantas tornam-se, geralmente, papilosas ou espinhosas, resinosas, mais tóxicas e suculentas, reduzindo a perda de água nas folhas ou armazenando água em seus tecidos foliares e/ou caulinares. São as plantas xerófitas e/ ou xeromórficas. Para evitar altas taxas de evaporação e transpiração, aumentam a espessura de sua cutícula e da cobertura de cera (superfície impermeabilizante e refletora), diminuem sua superfície foliar, até chegar a reduzi-las a espinhos. Realizam maior controle na abertura de estômatos, que se tornam mais profundos dentro da epiderme espessada e reforçada por hipoderme espessa e esclerificada. Muitas vezes, seus estômatos permanecem fechados durante o dia, abrindo-se apenas à noite (quando a temperatura cai e a taxa de evaporação tende a diminuir) para captação do $\mathrm{CO}_{2}$, praticando o metabolismo tipo CAM. As plantas com esse tipo de metabolismo acumulam o $\mathrm{CO}_{2}$, na forma de ácidos orgânicos, nos vacúolos das células do mesófilo, para utilizá-lo, na fotossíntese, durante o dia. Suas raízes tornam-se, geralmente, suculentas e / ou pivotantes e profundas em climas mais secos.

Por outro lado, plantas halófitas, que crescem preferencialmente em condições de salinidade, em solos à beira-mar ou em areias salgadas de deserto como, e.g., plantas de mangues, acumulam cloreto de sódio dentro de vacúolos ou desenvolvem resistência à entrada do cloreto de sódio ou ainda diluem este sal após sua entrada na planta (Alquini et al., 2003; Raven et al., 2007). Estas plantas podem mostrar também feições xeromórficas (Moisan et al., 2011), já que apesar de estarem perto de corpos de água, esta não está disponível para a realização das suas funções metabólicas. 


\section{EVIDÊNCIAS MORFOADAPTATIVAS PALEOCLIMÁTICAS DA PALEOFLORA EOCRETÁCEA DO CRATO}

Feições morfoanatômicas adaptativas para clima semiárido a árido são observadas entre as plantas identificadas na paleoflora eocretácea do Crato. Os fitofósseis desta unidade estão preservados como impressões, moldes e substituições por goethita e raramente incarbonizados. Estão esparsos em vários níveis do calcário e se apresentam na forma de órgãos destacados ou em conexão.

Listando os elementos componentes da paleoflora equatorial do Crato, já descritos ou apenas preliminarmente identificados tem-se a Tabela 1.

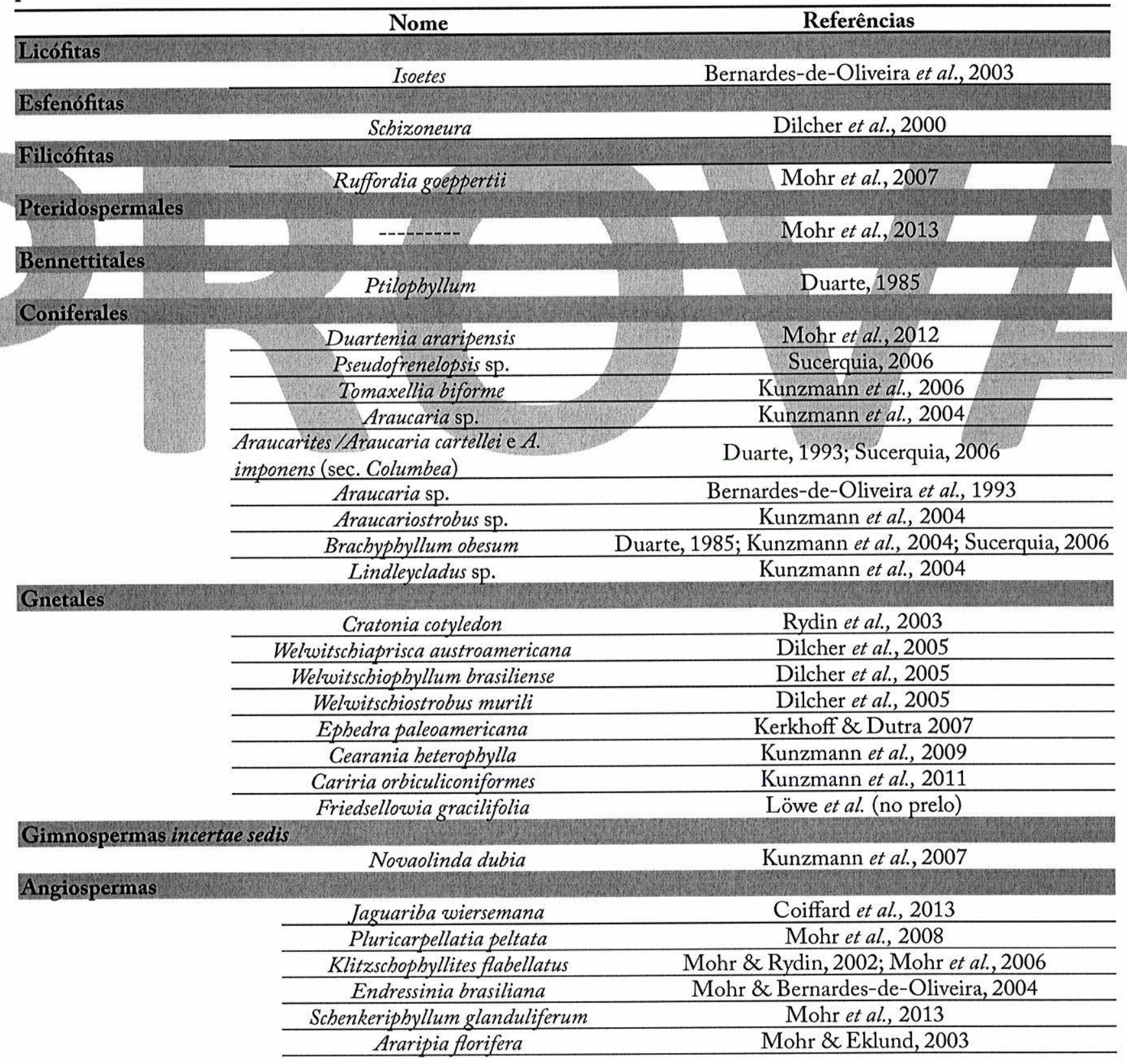

Tabela 1. Lista de espécies da paleoflora equatorial do Crato, já descritas ou apenas preliminarmente identificadas. 
O clima semiárido da atual caatinga nordestina, como o sugerido para o momento da deposição da Formação Crato, aparentemente, seria incompatível com as exigências ambientais de plantas como as monilófitas (=esfenófitas + filicófitas) e as licófitas, geralmente associadas ao alto teor de umidade e sombreamento. Entretanto, conforme Xavier et al. (2012), no atual Brasil semiárido, há cerca de 10 famílias desses grupos vegetais, envolvendo 20 gêneros e, pelo menos, 41 espécies. Ocorrem, é certo, em microhabitats úmidos e sombreados: fendas de rochas, barrancos sombreados, nascentes, lagoas temporárias ou áreas com solos temporariamente alagados. Adaptações estratégicas relacionadas à sobrevivência em estações secas como esporos alojados em cormos subterrâneos, observáveis em Isoetes luetzelburgii e esporocarpos em Salviniales, e o compartilhar de hábitos aquáticos de grande número de espécies licofíticas e de monilófitas também podem ser responsáveis pela boa representatividade desses grupos (Windisch, 1990; Kornás, 1985).

Em termos palinoflorísticos as licófitas estão bem representadas pelas famílias Lycopodiaceae, através da presença de esporos dos gêneros Camarozonosporites, Foveotriletes, Perotrilites, Retitriletes, Reticulatisporites e Sestrosporites; Selaginellaceae com os gêneros Aequitriradites, Echinatisporis Apiculatisporis, Densoisporites e Laevizonosporites. A Família Isoetaceae se encontra menos representada na palinoflora do Crato, contando apenas com megásporos triletes e micrósporos monoletes (Lima, 1978).

Escassos eixos caulinares esfenofíticos foram mencionados e atribuídos aos morfogêneros Schizoneura, por Dilcher et al. (2000), formas de amplitude mundial no Mesozoico, que evidenciariam vegetação marginal a corpos de água doce. Não estariam ligados a um clima em particular, preferindo, entretanto, os tropicais a subtropicais. Representantes de esfenófitas na palinoflora da Formação Crato são escassos e estão representados por esporos monoletes. Sua escassez poderia corroborar a ideia de pouca disponibilidade de água.
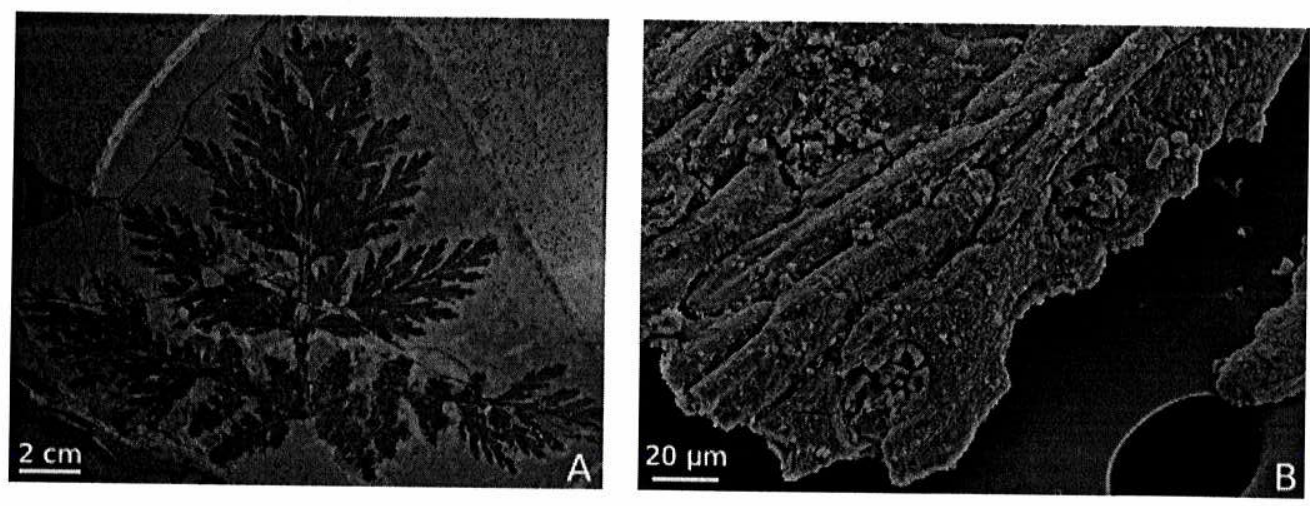

Figura 2. Indicadores paleoambientais em espécimes da espécie Ruffordia goepperti da Formação Crato. A. Aspecto geral da planta mostrandouma fronde com pinulas distais estéreis e proximais férteis. B. Detalhe da epiderme da fronde mostrando bases de pelos (Mohr et al., 2007).

As Anemiaceae e Gleicheniaceae tiveram suas presenças detectadas palinologicamente na paleoflora por Lima (1978 e 1979) de uma forma bem diversificada. Anemiaceae corresponde ao taxon mais comum dentre as Monilófitas presentes na flora do Crato. Quase todos seus espécimes pertencem ao feto extinto Ruffordia goeppertii, (Figura 2) segundo Mohr et al. (2007). São formas relativamente comuns no semiárido do nordeste brasileiro nos dias atuais, com várias espécies do tipo hemicriptófito (= com vida apenas das partes subterrâneas, na estação seca), terófito (= com vida apenas esporomórfica, na estação seca) e de padrão sazonal ativo na estação chuvosa (Pietrobom \& 
Barros, 2003; Xavier et al., 2012), portanto, de exigências compatíveis com o clima semiárido a árido do Eocretáceo do Araripe.

O gênero Gleichenia, também ali presente, trata-se como bem lembra Mohr et al. (2007), de elemento pioneiro em áreas devastadas, isto é, de áreas ensolaradas e secas.

Os esporos afins às filicófitas são os mais abundantes na palinoflora preservada, contribuindo com formas lisas (gêneros Deltoidospora, Cyathidites, Biretisporites, Auritulinasporites e Gleichenidites) e formas ornamentadas (gêneros Cicatricosisporites, Apendicisporites, Kuklisporites, Verrucosisporites e Trilobosporites). As formas ornamentadas são, notadamente, as mais abundantes e afins às Anemiaceae (Figura 3).

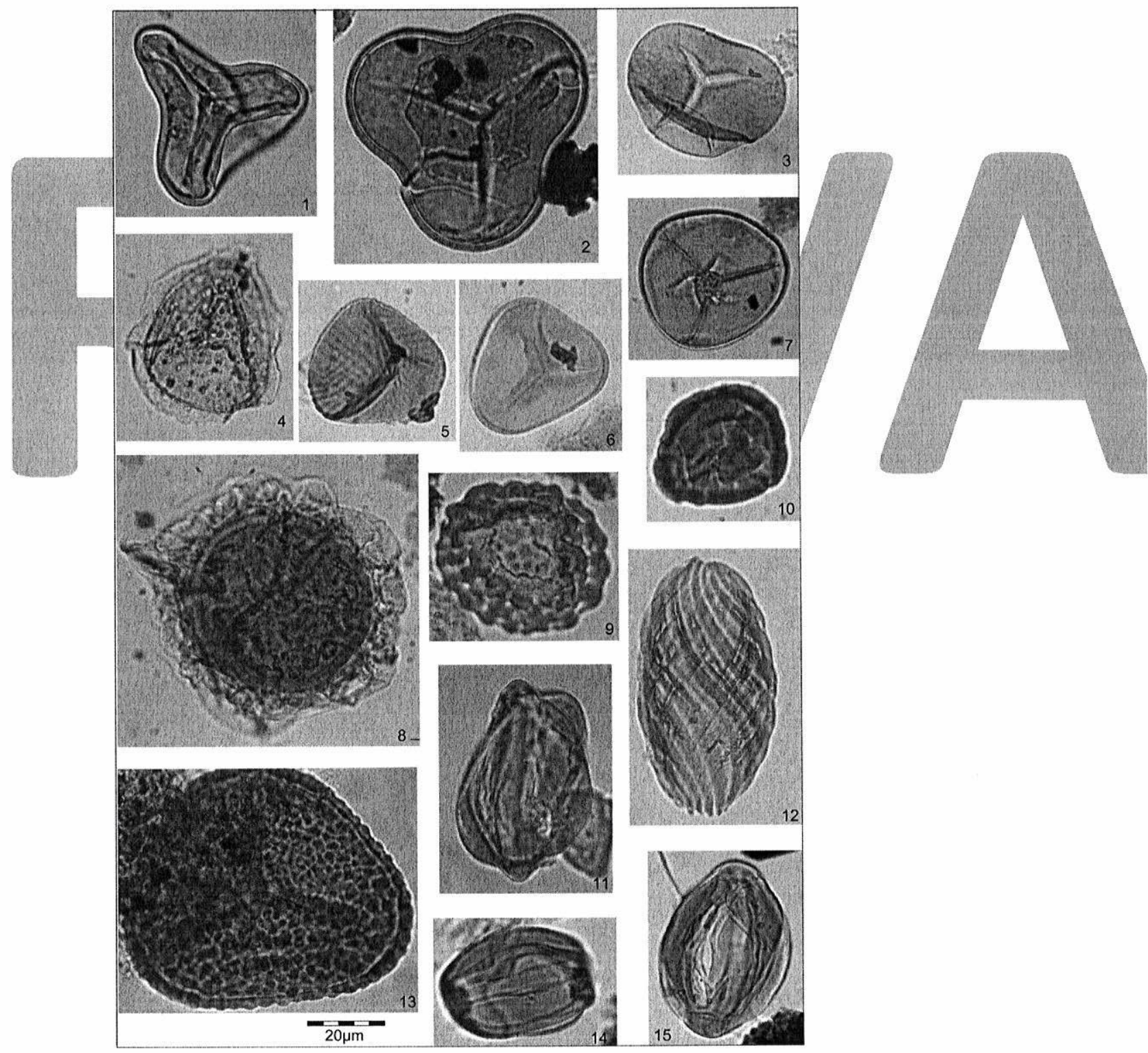

Figura 3. 1- Dictyophyllidites sp.; 2- Cyathidites australis; 3- Cyathidites minor; 4- Aequitrirradites baculatus; 5Cicatricosisporites venustus; 6- Matonisporites sp.; 7-Biretisporites sp.; 8- Crybelosporites pannuceus; 9- Klukisporiles variegatus; 10- Leptolepidites psarosus; 11- Equisetosporites irregularis; 12- Gnetaceaepollenites jansonii; 13Trilobosporites sp. cf. T. humilis; 14-Equisetosporites strigatus; 16-Equisetosporites irregulares. 
As gimnospermas constitutem o grupo de plantas dominantes na paleoflora do Crato. Conforme Mohr et al. (2007) e Mohr et al. (2012), incluem entre elas pteridospermas, benetitales, coniferales, gnetófitas (efedróides e welwitschióides), plantas de afinidades gnetaleanas e plantas de afinidades desconhecidas. Corroborando com os dados macroflorísticos, a palinoflora presente mostra um espectro polínico com amplo predomínio dos grãos de pólen afins às gimnospermas, onde se incluem formas monossacadas, bissacadas, inaperturadas, monocolpadas (Figura 4) e, particularmente abundantes, as formas rimuladas (Classopollis) e poliplicadas (Equisetosporites e Gnetaceaepollenites).

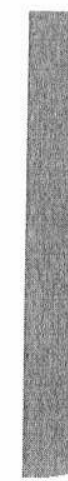
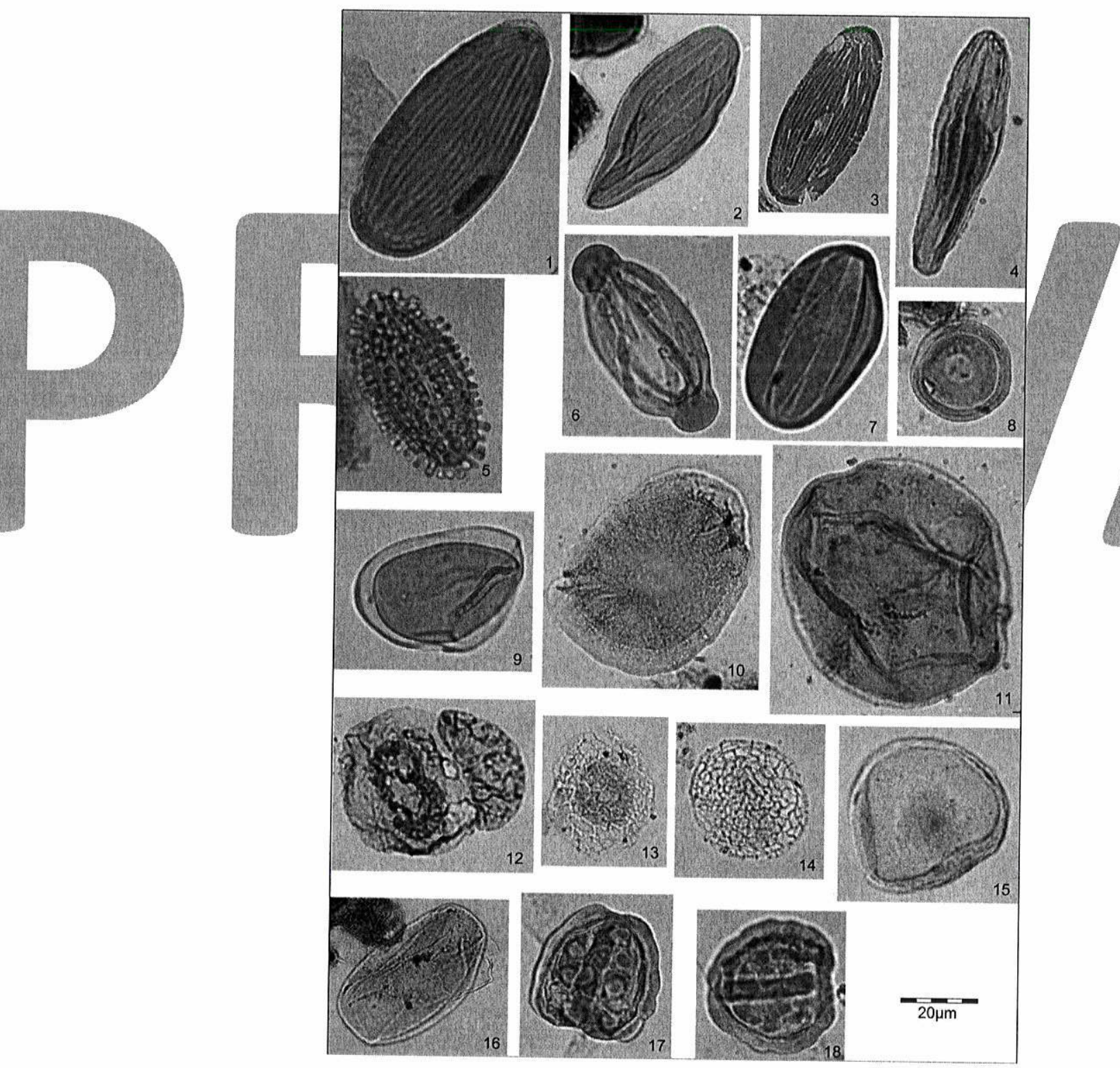

Figura 4. 1- Equisetosporites multicostata; 2- Equisetosporites consinnus; 3- Equisetosporites multicostata; 4Equisetosporites maculosus; 5- Reyrea polymorphus; 6- Steevesipollenites cf. S. binodosus; 7- Eqisetosporites strigatus; 8- Classopollis classoides; 9- Properinopollellites sp.; 10-Caliallasporites dampieri; 11-Araucariacites australis; 12 - cf. Alisporites; 13-Afropollis jardinus; 14-Afropollis zonatus; 15 - Uesugipollenites callosus; 16-Cycadopites sp; 17-Sergipea variverrucata; 18- Sergipea variverrucata. 
A fronde de pteridosperma descrita para a Formação Crato (Mohr et al., 2007), com seus longos eixos di- ou tricotomizados, e suas pequenas lâminas pinulares, assim como todo o corpo recoberto por tricomas sugere adaptações a climas mais secos. As pteridospermas estão presentes de forma rara na palinoflora, representadas pelos grãos de pólen do gênero Vitreisporites.

As benetitales parecem ter sido uma linhagem altamente adaptada para comunidades pioneiras, ou estrato médio de florestas maduras, florestas abertas, savanas ou vegetação costeira tipo mangue. Algumas delas também são positivamente correlacionadas com a presença de charcoals, o que sugere tolerância à natureza pioneira pós-incêndio (Zamuner, 2011). Estão representadas na paleoflora pelo gênero Ptilophyllum Morris (Duarte,1985). Provavelmente, foram adaptadas a uma vegetação rala tipo savana ou à vegetação marginal ao paleolago salobro do Crato. Conforme Dower et al. (2004), as benetitales exibem características tais como pinas espessas e densamente papiladas que são ligadas a aridez. Entretanto, faltam ainda estudos epidérmicos detalhados de suas estruturas adaptativas, na paleoflora do Crato. Palinomorfos produzidos por esta vegetação apresentam distribuição irregular na Formação Crato e estão pouco representados na palinoflora recuperada, até o momento, onde se destacam os gêneros de formas monocolpadas, Bennettitaepollenites, Cycadopites e Cavamonocolpites (Figura 4).

Coniferales constitutem um dos grupos mais diversificados da paleoflora do Crato, sendo conhecido por palinomorfos e por macrofósseis na forma de frondes, cones e escamas de cones. São reconhecidos representantes das cheirolopidiáceas e araucariáceas.

As coníferas da família Cheirolepidiaceae existiram somente durante o Mesozóico, com ampla diversidade morfológica e ecológica. Alguns elementos foram árvores de vários metros de altura, enquanto outros são interpretados como pequenas ervas ou arbustos, conforme descrito por Taylor et al. (2009). A parentemente, o único caráter unificante é o grão de pólen do tipo Classopollis (Figura 4.8). Este aparece em assembleias palinológicas que contém outros elementos típicos de áreas secas e sedimentos que evidenciam aridez (Pocock \& Jansonius, 1961).

As cheirolepidiáceas presentes na macroflora da Formação Crato apresentam caracteres morfológicos e anatômicos como folhas reduzidas e adpressas em Brachyphyllum obesum (Figuras 5A e B) e Pseudofrenelopsis (Figuras $5 \mathrm{C}$ a E), além de cutículas espessas, papilas, estômatos imersos na epiderme, que corroboram o seu caráter xerofítico. A aparência suculenta de ramos, onde as folhas portam tricomas, presente em Tomaxellia, bem como as folhas coriáceas, adpressas, com tricomas e o possível crescimento caulinar retorcido em Duartenia araripensis, podem ser evidências de adaptações a um clima semiárido a árido. Teriam como habitat preferencial as regiões arenosas costeiras, ribeirinhas ou pantanosas de corpos aquosos salinos ou salobros.

Os grãos de pólen produzidos pelas cheirolepidiáceas são atribuídos ao gênero Classopollis que, quantitativamente, é o gênero melhor representado na palinoflora, presente de forma regular e constante em toda a seção do Crato, com percentuais acima de $80 \%$ da associação.

As araucariáceas estão representadas na palinoflora por grãos de pólen tipo Araucariacites (Lima, 1979; Portela, 2008 e Rios-Netto, 2011), mas também por macrofósseis como cones femininos cf. Araucaria (Kunzmann et al., 2004), escamas araucarióides Araucarites (Duarte, 1993; Sucerquia, 2006), folhas destacadas (Bernardes-de-Oliveira et al., 1993) e ramos folhosos vegetativos de Brachyphyllum obesum Heer (Duarte, 1985; Kunzmann et al., 2004) e de espécies novas ainda não publicadas (Sucerquia, 2006). Ramos folhosos de Lindleycladus Harris, uma conífera de afinidade desconhecida e de distribuição geográfica ampla no Mesozoico, foram detectados por Kunzmann et al. (2004). 

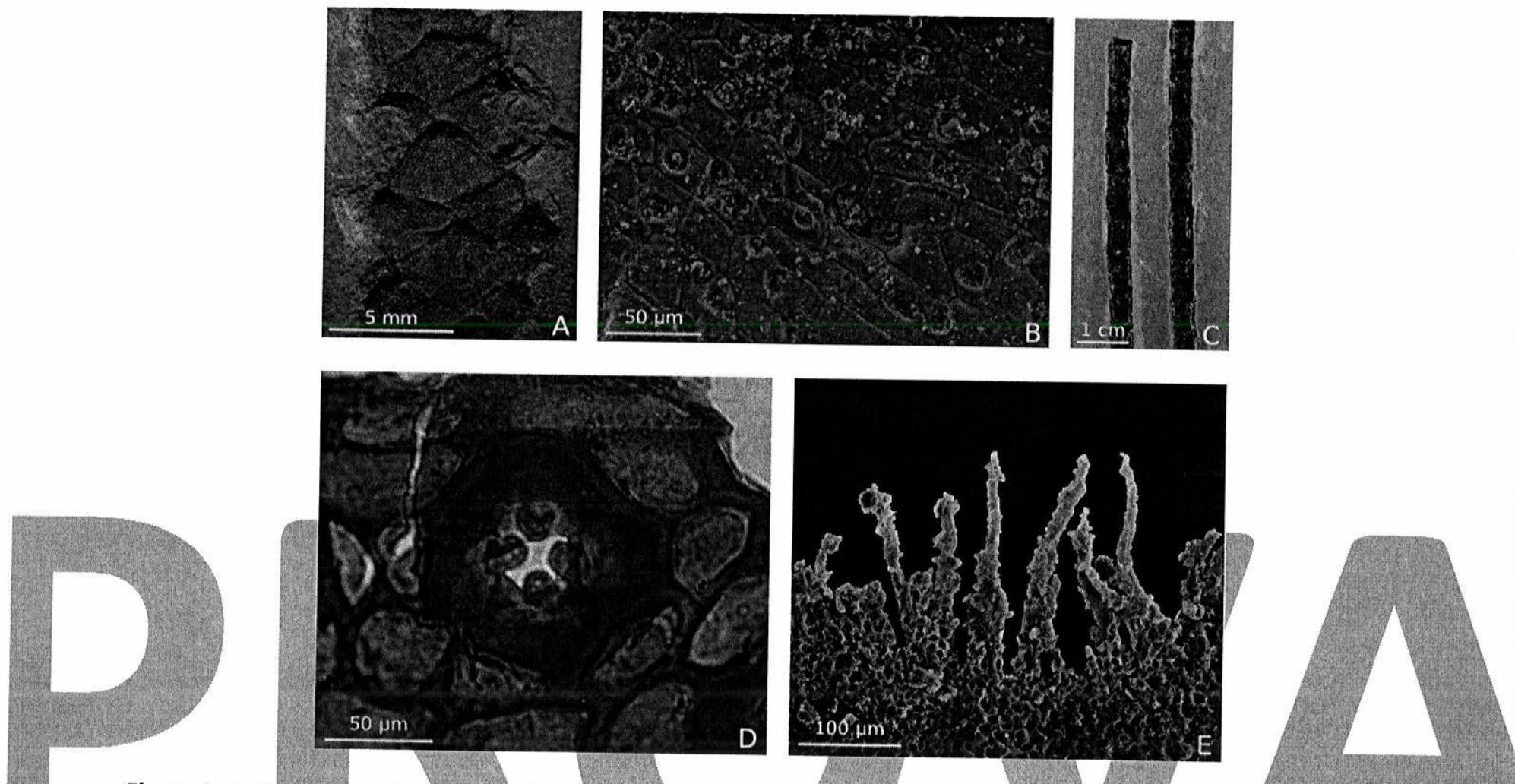

Figura 5. Indicadores paleoambientais em coníferas da Formação Crato. A. Ramo folhoso de Brachyphyllum obesum mostrando folhas pequenas adpressas e de aparência suculenta. B. Epiderme de Brachyphyllum obesum com marcas de pelos e/ou papilas e estômatos afundados. C. Ramo folhoso de Pseudofrenelopsis sp. mostrando as folhas adpressas. D. Cutícula de Pseudofrenelopsis sp. mostrando aparelho estomático com a abertura coberta por papilas. E. Detalhe do ápice da folha de Pseudofrenelopsis sp. mostrando a margem coberta de pelos Sucerquia, 2006).

A presença de araucariáceas está relacionada com condições climáticas especificamente mais secas. Elas entraram em declínio de abundância e distribuição a partir do Eocretáceo. Embora isto possa ser, parcialmente, relacionado com a evolução das angiospermas, o clima mais úmido e a temperatura mais elevada do Mesocretáceo podem ter colocado as araucárias em desvantagem. $\mathrm{O}$ seu declínio em diversidade sugere o desenvolvimento de florestas densas e pobres em espécies, em condições mais secas do Neógeno (Kershaw \& Wagstaff, 2001).

Estranhamente, Novaolindia dubia (Kunzmann et al., 2009), gimnosperma de afinidades desconhecidas, parece não apresentar feições adaptativas para clima árido, exceto, provavelmente por suas folhas pequenas.

Os primeiros reconhecimentos da presença de gnetaleanas efedróides na macroflora do Crato foram feitos por Pons et al. (1992) e de welwitschióides por Bernardes-de-Oliveira et al. $(1999,2000)$, mas também gnetófitas de afinidade incerta e/ou pertencentes a grupos extintos foram descritas.

Em 2000, Mohr \& Friis reconheceram plantas de afinidades gnetaleanas na macroflora e, logo a seguir, Rydin et al. (2003) descreveram uma plântula welwitschióide que designaram Cratonia cotyledon.

Dilcher et al. (2005) observaram estruturas welwitschióides vegetativas e reprodutivas as quais denominaram: a plântula, em estágio mais avançado do que a anterior, de Welwitschiella austroamericana, folhas isoladas de Welwitschiophyllum brasiliense e estróbilos masculinos de Welwitschiostrobus murili. Biemann (2012), ao estudar a anatomia do holótipo de Welwitschiophyllum brasiliense, detectou, sobre a 
lâmina de venação paralelódroma, a presença de estômatos dispostos entre faixas longitudinais muito finas de fibras epidérmicas esclerificadas e, em secção foliar transversal, estruturas estomáticas em cripta, parênquima paliçádico com lacunas preenchidas por calcita de prováveis cavidades ocupadas por fibras e feixes venosos, circundadas por uma bainha de células parenquimáticas ou de tecido de transfusão. Muitas dessas estruturas revelam adaptações a condições climáticas áridas (Figura 6 A).
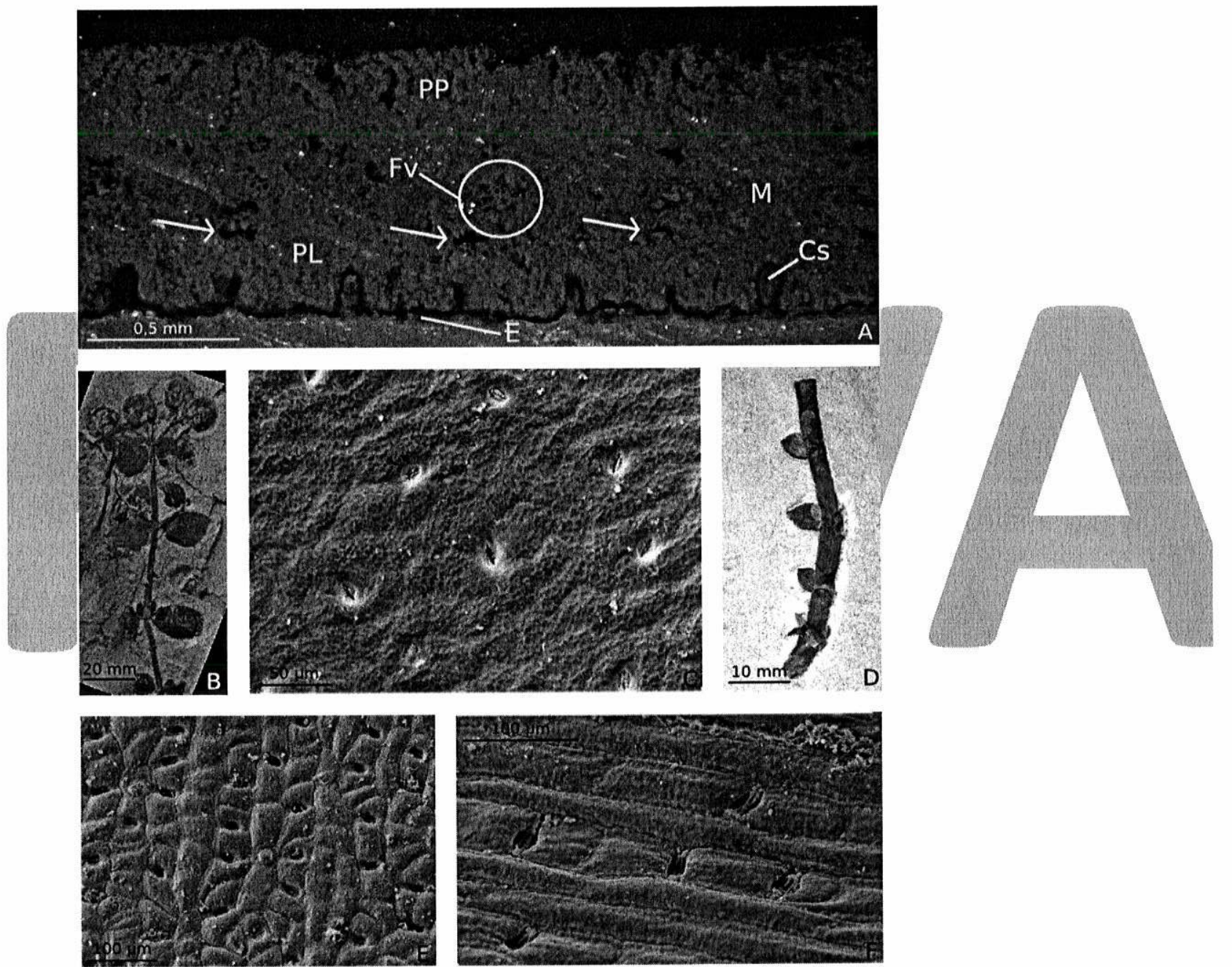

Figura 6. Indicadores paleoambientais em Gnetaleanas da Formação Crato. A. Secção transversal de folha de Welwitschiophyllum mostrando cavidades estomáticas (Cs), epiderme (E), mesófilo (M), Feixe vascular (Fv), Parênquima paliçádico (PP), Parênquima lacunoso (PL) e as setas indicam a provável posição das fibras. B. Aspecto geral de Cariria orbiculiconiformis mostrando as folhas esparsas e coriáceas. C. Epiderme de Cariria orbiculiconiformis mostrando estômatos afundados. D. Aspecto geral de Cearania heterophylla mostrando as folhas esparsas e coriáceas. E. Epiderme de Cearania heterophylla mostrando estômatos afundados. F. Detalhe da epiderme de Cearania heterophylla mostrando estômatos afundados (Biemann, 2012).

Em 2006, Fantom et al. também descreveram uma pequena erva lenhosa, de sistema radicular fasciculado, de caule articulado, com ramos opostos e articulados, folhas oblongas, curtas, de filotaxia oposta e venação paralela e estróbilos de posição axilar sobre folhas dos ramos caulinares, que consideraram gnetaleana efedróide ou gnetóide. 
Kerkhoff \& Dutra (2007) identificaram uma forma efedróide na flora, que designaram Ephedra paleoamericana. Conforme descrição trata-se de um ramo articulado fértil, com ramificação dicasial, áfilo, com estriações longitudinais, cuja estrutura reprodutiva dotada de oito a dez brácteas lenhosas, de disposição verticilada e não conata seria sugestiva de estróbilo masculino. O caráter áfilo dessa forma pode ser interpretado como uma das feições adaptativas ao ambiente árido.

Possíveis gnetaleanas tais como Cearania heterophylla (Kunzmann et al., 2009), Cariria orbiculiconiformes (Kunzmann et al., 2011) e Friedsellowia gracilifolia (Löwe et al., no prelo), descritas com base em macrofósseis do Crato, também apresentam entre suas feições adaptativas para clima árido: folhas esparsas e coriáceas, estômatos afundados, raízes pivotantes profundas, etc (Figuras $6 \mathrm{~B}-\mathrm{F}$ ).

Gnetaleanas efedráceas são, hoje, encontradas em regiões áridas da Eurásia e das Américas do Norte, Central e do Sul, enquanto welwitschiáceas encontram-se apenas numa faixa costeira desértica entre Namibia e Angola (Kubitski, 1990), em condições de precipitação de 10 a $100 \mathrm{~mm}$ por ano. Ambas apresentam características xerofíticas típicas: em efedráceas - folhas são reduzidas a escamas; estômatos, afundados na epiderme, enquanto células epidérmicas e parênquima cortical, incrustados de oxalato de cálcio e em welwitschiáceas - o caule é lenhoso, em forma de cone curto; folhas são coriáceas; estróbilos densos; raiz pivotante; epiderme com parede externa espessa, estômatos afundados
na epiderme.

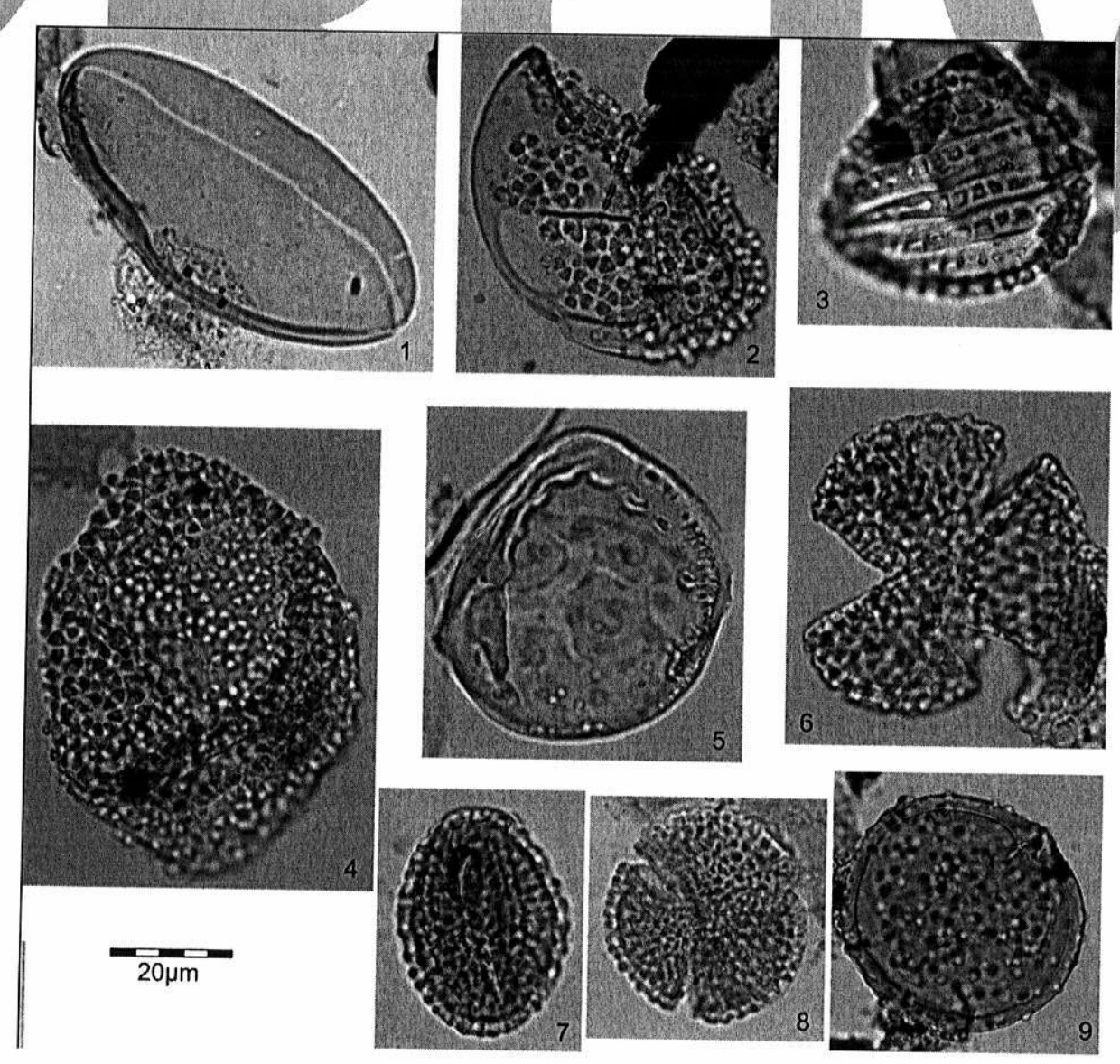

Figura 7. 1- Schizosporis parvus; 2- Stelatopollis dubius; 3- Cornetipollis perforatus; 4- Stelatopollis araripensis; 5 Antusporites baculatus; 6-Albertipollenites sp.; 7-Retitricolpites sp.; 8-Retitricolpites sp.; 9-Pilosisporites trichopapillosus. 
As gnetales representam, juntamente com as cheirolepidiáceas, um dos componentes mais típicos e representativos da palinoflora do Crato, com altas diversidade e frequência de espécies. Trata-se de um grupo de palinomorfos constituídos por, pelo menos, sete gêneros (Equisetosporites, Singhia, Welwitschiapites, Steevesipollenites, Regalipollenites, Gnetaceaepollenites e Cornetipollis), perfazendo um percentual no espectro polínico recuperado ao redor de 30\% (Figuras 4 e 7).

O documentário fóssil revela que as angiospermas têm origem e predomínio ecológico relativamente recente, apesar de seu exuberante domínio atual. A primeira radiação delas deu-se durante o Neovalanginiano a Eobarremiano ( $135-128 \mathrm{Ma}$ ) e ao redor do Neobarremiano ao Aptiano, já apresentavam uma razoável diversidade taxonômica, na faixa paleoequatorial (Barale, 1990).

As angiospermas presentes na paleoflora da Formação Crato não foram tão comuns como as gimnospermas, entretanto apresentavam já uma razoável diversificação em angiospermas basais, magnoliídeas, monocotiledôneas e eudicotiledôneas, conforme os fitofósseis identificados que consistem em folhas isoladas, frutos, sementes e plantas quase completas, inclusive portando estruturas floríferas (Mohr \& Friis, 2000; Mohr et al., 2007, Coiffard et al., 2013).

Da ordem Nymphaeales Dumort há representantes tanto das Nymphaeaceae (Jaguariba Coiffard et al., 2013) como das Cabombaceae (Pluricarpellatia Mohr et al., 2008) que, juntamente com Klitzschophyllites, uma possível monocotiledônea (Mohr \& Rydin, 2002; Mohr et al., 2006), compõem o cenário das plantas aquáticas do paleolago do Crato. Diferentemente das plantas terrestres alóctones, as plantas aquáticas ninfealeanas do paleolago não apresentam feições adaptativas para clima seco a não ser folhas reduzidas e relativamente espessas, com espinhos ou tricomas. Klitzschophyllites Mohr et al., 2006 era dotada de caule mais forte e portava glândulas de sal nas margens foliares (Figuras $8 \mathrm{~A}-\mathrm{B}$ ).

O clado das Magnoliídeas está representado por elementos fossilíferos das ordens Magnoliales e Laurales que se constituem em fonte de informação sobre a morfologia das angiospermas na faixa paleotropical ecretácea.

Dentre as Magnoliales presentes na Formação Crato, Endressinia (Mohr \& Bernardes-deOliveira, 2004) apresenta como características adaptativas a climas mais secos: folhas hipoestomáticas, com aspecto coriáceo e inflexível dotadas de células de óleos eterais (Figuras $8 \mathrm{C}$ e D).

Morales (2002) aventou a hipótese de que a alta produção de óleos eterais pode estar associada à adaptação a um clima mais seco, porque as substâncias voláteis ao evaporarem, criam em volta da planta uma atmosfera saturada que torna a perda de água mais difícil. Este poderia também ser o caso da magnolialeana Endressinia. Schenkeriphyllum (Figuras 8 E-G) é outra magnolialeana da flora do Crato (Mohr et al., 2013) que apresenta como feições adaptativas xeromórficas: eixos cobertos por glândulas de óleos eterais, folhas pequenas, sésseis e invaginantes, de ápices redondos a retusos, duras e coriáceas, com epiderme e cutícula espessas, estômatos apenas na face abaxial, com possíveis células de óleos eterais e frutos secos. 

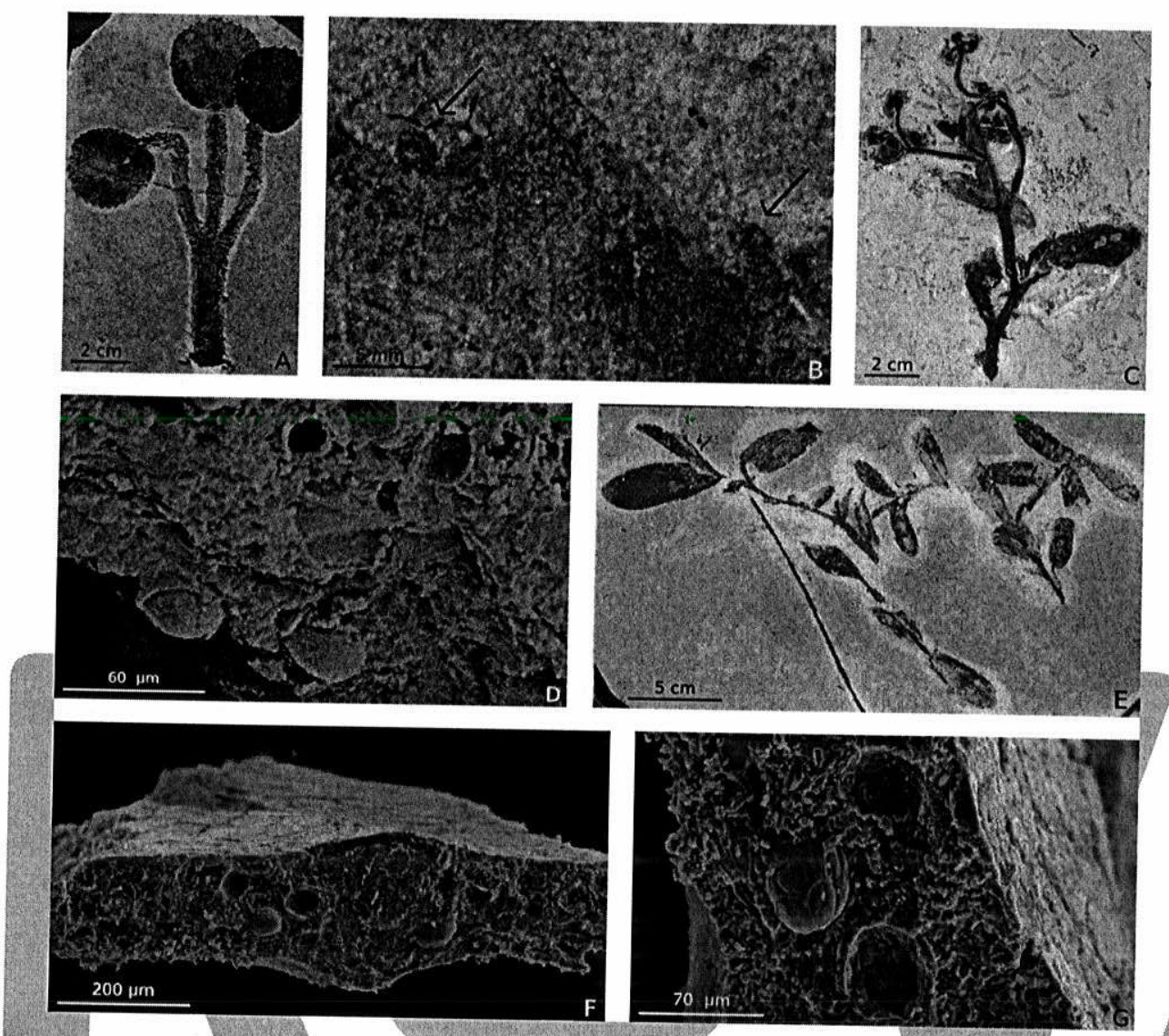

Figura 8. Indicadores paleoambientais em angiospermas da Formação Crato. A. Aspecto geral de Klitzschophyllites flabellatus mostrando as folhas espessas e caules fortes. B. Detalhe da margem da folha de Klitzschophyllites flabellatus mostrando as glándulas de sal (setas). C. Endressinia brasiliana mostrando folhas de aspecto coriaceo e inflexível. D. Detalhe da folha de Endressinia brasiliana mostrando as células de óleos eterais. E. Schenkeriphyllum glanduliferum mostrando as folhas pequenas e coriáceas. F-G. Detalhe da folha de Schenkeriphyllum glanduliferum mostrando as células de óleos eterais.

Outra magnoliídea de possível afinidade às lauraleanas é Araripia (Mohr \& Eklund, 2003), entre cujas feições adaptativas xeromórficas preservadas há apenas folhas pequenas.

Dentre os fitofósseis de provável afinidade com monocotiledôneas, além da já mencionada Klitzschophyllites, está uma forma ainda não publicada, descrita por Leme et al. (no prelo) como proximamente, relacionada à linhagem-tronco da qual divergiram as Bromeliáceas viventes. Suas feições adaptativas para clima seco são: ceras epicuticulares, espata produzindo abundante resina, tricomas peltados sobre vênulas transversais, cobertos longitudinalmente por cera epicuticular do tipo "strelitzia", estômatos paracíticos, com células subsidiárias protuberantes.

As Eudicotiledôneas, representadas provavelmente por Ranunculales e Proteales (Nelumbonaceae), podem estar presentes na paleoflora e constituem material ainda em estudo (Mohr et al., 2007).

Os palinomorfos, representantes da flora angiospérmica presentes na Formação Crato, estão restritos aos grupos dos monocolpados e tricolpados, e são considerados como afins às magnolí́deas. Dado que a Formação Crato é de idade aptiana, portanto depositada ainda no Eocretáceo, tal baixa diversidade de grupos é perfeitamente compreensível.Igualmente a representatividade dos palinomorfos 
afins às angiospermas é bastante baixa na palinoflora do Crato, algo ao redor de $15 \%$. Contudo, mostram boa diversidade com cerca de dez (10) gêneros (Clavatipollenites, Liliacidites, Stellatopollis, Retimonocolpites, Psilatricolpites, Tricolpites, Tricolpopollenites, Retitricolpites, Trichotomosulcites e Dicotetradites) (Figura 7). Desse modo, os dados palinoflorísticos indicam que as angiospermas, apesar de presentes e já um tanto diversificadas, ocupavam uma pequena porcentagem da flora do Crato (Lima, 1978; Dino, 1992 e Portela, 2008).

Todas as feições adaptativas das plantas da paleoflora do Crato apontam para um clima semiárido a árido, provavelmente com regime torrencial e esporádico de chuvas.

\section{REFERÊNCIAS BIBLIOGRÁFICAS}

ALQUINI, Y.; BONA, C.; BOEGER, M.R.T.; COSTA, C.G. \& BARROS, C. F. 2003. Epiderme. In: APPEZZATO-DAGLORIA, B. \& CARMELLO-GUERREIRO, S.M.(eds.).Anatomia Vegetal. UFV, Viçosa, p. 87-107.

ASSINE, M.L. 2007. Bacia do Araripe. Boletim de Geociências da Petrobras, 15(2): 371-389.

BARALE, G. 1990. Les stratégies adaptatives chez les végétaux du Trias supérieur au crétacé inférieur dans l'aire eurosienne, en relation avec l'évolution du climat. Comptes Rendus de l'Académie des Sciences, 311(1): 265-269.

BARRON, E.J. 1983. A warm equable Cretaceous: the nature of the problem. Earth Sciences Review, 19:305 338

BARRON, E.J. \& MOORE, G.T. 1994. Climate model application in paleoenvironmental analysis. SEPM Short Course no. 33. (Society for Sedimentary Geology) Tulsa, OK, USA, 339 p.

BARRON, E.J.; FAWCET, P.J.; POLLARD, D. \& THOMPSON, S. 1993. Model Simulation of Cretaceous climates: the role of geography and carbon dioxide. Philosophical Transaction of the Royal Society of London, B, 341: 307-316.

BERNARDES-DE OLIVEIRA, M.E.C.; BARRETO, A.M.F; DILCHER, D. \& MANDARIM-DE-LACERDA, A.F. 2003. Isoetes eocretáceo da Formação Crato, Formação Santana, Bacia do Araripe, Nordeste do Brasil. In: CONGRESSO BRASILEIRO DE PALEONTOLOGIA, XVIII, Brasília, Boletim de Resumos, Brasília, SBP, p. 68.

BERNARDES-DE-OLIVEIRA, M.E.C.; DILCHER, D.; MANDARIM-DE-LACERDA, A.F. \& PONS, D. 1999. Registro Aptiano-Albiano de Welwitschiaceae na Formação Santana, bacia do Araripe, Nordeste do Brasil. In: CONGRESSO BRASILEIRO DE PALEONTOLOGIA, 16, Crato (CE). Boletim de Resumos, Crato, SBP, p. 25-26.

BERNARDES-DE-OLIVEIRA, M.E.C.; DILCHER, D.; MANDARIM-DE-LACERDA, A.F.; PONS, D. \& RICARDIBRANCO, F. 2000. Gnetalean macrofossils of the Crato Member, Santana Formation, Late Aptian - Early Albian, Chapada do Araripe Brazil. In: INTERNATIONAL GEOLOGICAL CONGRESS, 30, Rio de Janeiro, Abstracts.., International Union of Geological Sciences and Geological Survey of Brazil, 2000, CD-ROM.

BERNARDES-DE-OLIVEIRA, M.E.C.; LIMA, M.R. \& PONS, D. 1993. Folhas de Araucariaceae da Formação Santana, Cretáceo do Nordeste Brasileiro. Anais da Academia Brasileira de Ciências, Resumos Comunicações, 65: 329-330. 
BIEMANN, E.P.G.E. 2012. Angiospermas eocretáceas do Membro Crato (Formação Santana, Bacia do Araripe, NE do Brasil): Revisão taxonômica de Welwitschiophyllum brasiliense Dilcher, Bernardes-de-Oliveira, Pons et Lott, 2005. Programa de PósGraduação em Análise Geoambiental, Universidade Guarulhos, Dissertação de Mestrado, 81p.

COIFFARD, C.; MOHR, B. \& BERNARDES-DE-OLIVEIRA, M.E.C. 2013. Jaguariba wiersemaniana gen. nov. et sp. nov., an Early Cretaceous member of crown group Nymphaeales (Nymphaeaceae) from northern Gondwana. Taxon, (no
prelo). CHALONER, W.G. \& McELWAIN, J. 1997. The fossil plant record and global climatic change. Review of Palaeobotany and
Palynology, 95 (1-4): 73-82.

CHUMAKOV, N.M. 1995. Climatic zone in the middle of the Cretaceous Period. Stratigraphy and Geological Correlations, 3: 3-14.

DILCHER, D.; MANDARIN-DE-LACERDA, A.F.; BARRETO, A.M.F. \& BERNARDES-DE-OLIVEIRA, M.E.C. 2000. Selected forms from the Santana Formation, Chapada do Araripe, Brazil. In: REUNIÃO DE PALEOBOTÂNICOS E PALINÓLOGOS, 10, 2000. Guarulhos, Revista Universidade Guarulhos, Geociências, V: 249-249.

DILCHER, D.L.; BERNARDES-DE-OLIVEIRA, M.E.C.; PONS, D. \& LOTT, T.A. 2005. Welwitschiaceae from the Lower Cretaceous of northeastern Brazil. American Journal of Botany, 92:1294-1310.

DINO, R. 1992. Palinologia, Bioestratigrafia e Paleoecologia da Formaşão Alagamar-Cretáceo da Bacia Potiguar, Nordeste do Brasil. Programa de Pós-Graduação em Geologia Sedimentar, Instituto de Geociências, Universidade de São Paulo, Tese de Doutorado, 299p.

DOWER, B.L.; BATEMAN, R. \& STEVENSON, D.W. 2004. Systematics, ontogeny, and phylogenetic implications of exceptional anatomically preserved cycadophyte leaves from the Middle Jurassic of Bearreraig Bay, Skye, Northwest Scotland. The Botanical Review, 70(2): 105-120.

DUARTE, L. 1985. Vegetais fósseis da Chapada do Araripe, Brasil. In: CONGRESSO BRASILEIRO DE PALEONTOLOGIA, 8 1983 , Coletânea de Trabalhos Paleontológicos, Série Geologia 27, Paleontologia e Estratigrafia, 2: 557-
563.

DUARTE, L. 1993. Restos de Araucariáceas da Formação Santana - Formação Crato (Aptiano), NE do Brasil. Anais do Academia Brasileira de Ciências, 65(4): 357-362.

FANTOM,J.C.M.; RICARDI-BRANCO, F.; DILCHER, D. \& BERNARDES-DE-OLIVEIRA, M.E.C. 2006. New gymnosperm related with gnetales from the Crato Palaeoflora (Lower Cretaceous, Santana Formation, Araripe Basin, Northeastern Brazil: Preliminary study. Geociências (São Paulo. Online), 25: 205-210,

FRAKES, L.A.; FRANCIS, J.E. \& SYKITUS, J.I. 1992. Climate modes of the Phanerozoic. The History of the Earth's Climate over the past 600 million years. Cambridge University Press, Cambridge. 274p.

GRADSTEIN, F.M.; OGG, J.G.; SCHMITZ, M.D. \& OGG, G.M. (eds.). 2012. The Geologic Time Scale 2012. Elsevier,

Oxford, Amsterdam. 2-Volume Set, 1st Edition. 1144p.

HAY, W.W. \& FLOEGEL, S. 2012. New thoughts about the Cretaceous climate and oceans. Earth-Science Reviews, 115: 262-272 
KELLER, G. 2008. Cretaceous climate, volcanism, impacts, and biotic effects. Cretaceous Research, 29: 754-771.

KERKHOFF, H.L.M. \& DUTRA, L.T. 2007. Uma nova Ephedraceae (Gnetales) da bacia do Araripe, Cretáceo Inferior, Brasil. In: CARVALHO, I.S.; CASSAB, R.C.T.; SCHWANKE, C.; CARVALHO, M. A.; FERNANDES, A.C.S.; RODRIGUES, M.A.C.; CARVALHO, M.S.S.; ARAI, M. \& OLIVEIRA, M.E.Q.(eds). Paleontologia: Cenários da Vida (Ed. Interciência), $1: 243-250$.

KERSHAW, P. \& WAGSTAFF, B. 2001. The Southern Conifer Family Araucariaceae: History, Status, and Value for Paleoenvironmental Reconstruction. Annual Review of Ecology and Systematics, 32: 397-414.

KIDDER, D.L. \& WORSLEY, T.R. 2010. Phanerozoic Large Igneous Provinces (LIPs) HEATT (Haline Euxinic Acidic Thermal Transgression) episodes and mass extinction. Palaeogeography, Palaeoclimatology and Palaeoecology, 295: $162-191$.

KORNÁS, J. 1985. Adaptative strategies of African pteridophytes to extreme environments. In: DYER, A.F. \& PAGE, C.N. (eds.). Biology of Pteridophytes. The Royal Society of Edinburg, pp. 391-396.

KUBITZKI, K. 1990. The families and genera of vascular plants - Pteridophytes and Gymnosperms. In: KRAMER, K. U. \& GREEN, P. S. (eds). v. 1.404 p.

KUNZMANN, L.; MOHR, B.A.R. \& BERNARDES-DE OLIVEIRA, M.E.C. 2004. Gymnosperms from the Early

Cretaceous Crato Formation (Brazil). I. Araucariaceae and Lindleycladus (incertae sedis). Mitt. Mus. Naturkde. Berlin, Geowiss.

Reibe, 7: 155-174.

KUNZMANN, L.; MOHR, B.A.R.; BERNARDES-DE OLIVEIRA, M.E.C. \&WILDE, V. 2006. Gymnosperms from the Lower Cretaceous Crato Formation (Brazil). II. Cheirolepidiaceae. Fossil Record, 9(2): 213-225.

KUNZMANN, L.; MOHR, B.A.R. \& BERNARDES-DE OLIVEIRA, M.E.C. 2007. Novaolindia dubia gen. et sp. nov., an enigmatic seed plant from the Early Cretaceous of northern Gondwana. Review of Palaeobotany and Palynology, 147: 94-105.

KUNZMANN, L.; MOHR, B.A.R. \& BERNARDES-DE OLIVEIRA, M.E.C. 2009. Cearania heterophylla gen. nov. et sp. nov., a fossil gymnosperm with affinities to the Gnetales from the Early Cretaceous of northern Gondwana. Review of Palaeobotany and Palynology, 158: 193-212.

KUNZMANN, L.; MOHR, B.A.R.; WILDE, V. \& BERNARDES-DE OLIVEIRA, M.E.C. 2011. A putative gnetalean gymnosperm Cariria orbiculiconiformis gen. nov. spec. nov. from the Early Cretaceous of northern Gondwana. Review of Palaeobotany and Palynology, 165: 75-95.

LARSON, R.L \& ERBA, E 1999. Onset of the mid-Cretaceous Greenhouse of the Barremian-Aptian: igneous events of the biological, sedimentary and geochemical responses. Paleoceanography, 14: 663-678.

LEME, E.M.C.; BROWN, G.K.; DILCHER, D.; BERNARDES-DE-OLIVEIRA, M.E.C.; SIQUEIRA-FILHO, J.A. \& SALES, A.M.F. (no prelo). Protoananaceae, a new monocot fossil family from Early Cretaceous of Northeast Brazil. American Journal of Botany, (no prelo)

LIMA, M.R. 1978. Palinologia da Formạ̧ão Santana (Cretáceo do Nordeste do Brasil). Instituto de Geociências, Universidade de São Paulo. Tese de Doutorado. 335 p. 
LIMA, M.R. 1979. Palinologia da Formação Santana (Cretáceo do Nordeste do Brasil). II Descrição sistemática dos esporos da Subturma Zonotriletes e Turma Monoletes e dos polens das Turmas Saccites e Aletes. Ameghiniana, 16(1-2): 27-63.

LÖWE, S.A.; MOHR, B.A.R.; COIFFARD, C. \& BERNARDES-DE-OLIVEIRA, M.E.C. (no prelo). Friedsellowia gracilifolia gen. nov. et sp. nov., a new gnetophyte from the Lower Cretaceous Crato Formation (Brazil). Palaeontographica.

MOHR, B.A.R. \& BERNARDES-DE-OLIVEIRA M.E.C. 2004. Endressinia brasiliana a magnolialean angiosperm from the Lower Cretaceous Crato Formation (Brazil). International Journal Plant Sciences, 165(6): 1121-1133.

MOHR, B.A.R.; BERNARDES-DE-OLIVEIRA M.E.C.; BARALE, G. \& OUAJA, M. 2006. Palaeogeographic distribution and ecology of Klitzschophyllites, an Early Cretaceous angiosperm in southern Laurasia and northern gondwana.
Cretaceous Research, 27:464-472.

MOHR, B.; BERNARDES-DE-OLIVEIRA, M.E.C. \& TAYLOR, D. W. 2008. Pluricarpellatia, a nymphaealean angiosperm from the Lower Cretaceous of northern Gondwana (Crato Formation, Brazil. Taxon, 57: 1147-1158.

MOHR, B.; BERNARDES-DE OLIVEIRA, M.E.C. \& LOVERIDGE, R.F. 2007. The macrophyte flora of the Crato Formation. In: MARTILL, D.M.; BECH, G. \& LOVERIDGE, R.F. (eds.). The Crato Fossil Beds of Brazil. Cambridge University Press, pp. 537- 573

MOHR, B.; COIFFARD, C. \& BERNARDES-DE OLIVEIRA, M.E.C. 2013 Schenkeriphyllum glanduliferum, a new magnolialean angiosperm from the Early Cretaceous of Northern Gondwana and its relationship to fossil and modern Magnoliales. Review of Palaeobotany and Palynology, 189: 57-72.

MOHR, B.A.R. \& EKLUND, H. 2003. Araripia florifera nov. gen. nov. sp., a putative lauralean angiosperm from the Lower Cretaceous Crato Formation (Brazil). Review of Palaeobotany and Palynology, 126: 279-292.

MOHR, B.A.R. \& FRIIS, E.M. 2000. Early angiosperms from the Lower Cretaceous Crato Formation (Brazil), a preliminary report. International Journal Plant Sciences, 161(Suppl.): S155-S167.

MOHR, B.A.R. \& RYDIN, C. 2002. Trifurcatia flabellata n. gen. n. sp., a putative monocotyledon angiosperm from the Lower Cretaceous Crato Formation (Brazil). Mitt. Mus. Naturk. Berlin, Geowiss. Reihe, 5: 335-344.

MOHR, B.; SCHULTKA, S.; SÜSS, H. \& BERNARDES-DE OLIVEIRA, M.E.C. 2012. A new drought resistant gymnosperm taxon Duartenia araripensis gen.nov. et sp. nov. (Cheirolepidiaceae?) from the Early Cretaceous of Northern Gondwana. Palaeontographica, Abt. B, 289(1-3): 1-25.

MOISAN, P.; VOIGT, S.; POTT, C.; BUCHWITZ, M.; SCHNEIDER, J. W. \& KERP, H. 2011. Cycadalean and bennettitalean foliage from the Triassic Madygen Lagerstätte (SW Kyrgyzstan, Central Asia). Reviezw of Palaeobotany and
Palynology, 164: 93-108.

MORALES, R. 2002- The history, botany and taxonomy of the genus Thymus. In: STAHL- BISKUP, E. \& SÁEZ, F. (eds.). Thyme, the genus Thymus, Taylor \& Francis, London, p.1-43.

NEUMANN, V.H. 1999. Estratigrafia, Sedimentologia, Geoquímica y diagénesis de los sistemas lacustres e aptiense-albienses de la cuenca de Araripe (Noroeste de Brasil). Universitat de Barcelona, DEP, DGPPG, Tesis Doctoral, 244p. 
PEAT, D.W. 1997.The Paraná-Etendeka Province. In: J.J. MAHONEY \& M.F. COFFIN (eds.). Large Igneous Provinces: Continental, Oceanic and Planetary Flood Volcanism. American Geophysical Union, p. 217- 245.

PIETROBOM, M.R. \& BARROS, I.C.L. 2003. Pteridófitas de um fragmento florestal na Serra do Mascarenhas, Estado de Pernambuco, Brasil. Insula, 32: 73-118.

PIRES, E.F. 2008. Análises dendrológicas no Cretáceo Inferior das bacias do Araripe e Paraná: determinação de paleoclimas regionais e relaçäo com biomas globais do mesozoico. Instituto de Geociências, Universidade Federal do Rio Grande do Sul, Tese de Doutorado, $180 \mathrm{p}$.

POCOCK, S.J. \& JANSONIUS, J. 1961. The pollen genus Classopollis Pflug 1953. Micropaleontology, 7(4): 439-449.

PONS, D.; OLIVEIRA-BABINSKI, M.E.C.B. \& LIMA, M.R. 1992. Les Ephédrales de La Formation Santana, Crétacé Inférieur du bassin d Araripe (Brésil). In: CONFERENCE DE L'ORGANISATION INTERNATIONALE DE PALÉOBOTANIQUE, 4, Paris, Abstracts, Paris, p. 125.

PORTELA, H.A. 2008. Estudo Palinológico e Palinofaciológico da Formạ̧ão Santana, Bacia do Araripe, Nordeste do Brasil. Faculdade de Geologia, Universidade do Estado do Río de Janeiro, Dissertação de Mestrado, 133p.

PREMOLI-SILVA, I; ERBA, E.; SALVINI, G.; LOCATELLI, C. \& VERGA, D. 1999. Biotic changes in Cretaceous oceanic anoxic events of the Tethys: Journal of Foraminiferal Research, 29:352-370.

RAVEN, P.H.; EVERT, R.F. \& EICHORN, S.E. 2007. Biologia Vegetal. 7ed. Editora Guanabara Koogan S.A., Rio de Janeiro, $728 \mathrm{p}$.

RIOS-NETTO, A.M. 2011. Evolução Paleoambiental e Palinoestratigrafia do Intervalo Alagoas na parte oriental da Bacia do Araripe, Nordeste do Brasil. Programa de Pós-Graduação em Geologia, Instituto de Geociências, Universidade Federal do Rio de Janeiro, RJ, Tese de Doutorado, 304p.

RYDIN, C.; MOHR, B.A.R. \& FRIIS, E.M. 2003. Cratonia cotyledon gen.et sp. nov.: A unique Cretaceous seedling related to Welwitschia. Proceedings Royal Society London, Ser. B, Biol. Sci (Suppl.), 270: S29-S32.

SCHLANGER, S.O \& JENKYNS, H.C. 1976. Cretaceous oceanic anoxic events causes and consequences: Geologie en Mijnbouwe, 55: 169-184.

SELDEN, P. A. \& NUDDS, J. R. 2005. Evolution of Fossil Ecosystems. Manson Publishing Ltd., 160p.

SELLWOOD, B.W \& VALDES, P.J. 2006. Mesozoic Climates: general circulation models and the rock models. Sedimentary Geology, 190: 269-287.

SKELTON, P. (ed.). 2003. The Cretaceous World. Cambridge University Press, 360 p.

SLOAN, L.C \& BARRON, E.J. 1990. “Equable” climate during Earth History? Geology, 18: 489-492.

SUCERQUIA, P. A. 2006 - Gimnospermas eocretáceas da Formafão Crato, Bacia do Araripe, Nordeste do Brasil. Programa de PósGraduação em Geologia Sedimentar, IGc/USP, São Paulo, SP, Dissertação de Mestrado, 108p. 
TAYLOR, T.N.; TAYLOR, E.L. \& KRINGS, M. 2009. The biology and evolution of fossil plants. $2^{\text {nd }}$ Edition, Academic Press by Elsevier, San Diego, CA. 1230 p. VALDES, P.J.; SELLWOOD, B.W. \& PRICE, G.D. 1996. Evaluating concepts of Cretaceous Equability. Paleoclimate, 2:
139-158.

WIGNALL, P.B. 2001. Large Igneous Provinces and mass extinctions. Earth Sci. Rev., 53: 1-33.

WINDISCH, P.G. 1990. Pteridófitas da região norte-ocidental do Estado de São Paulo - Guia para excursöes. 2a . Ed., UNESP, São Paulo, 110p. WOODWARD, F.I. \& WILLIAMS, B.G. 1987. Climate and plant distribution at global and local scales. Vegetation, 69: 189-
197.

XAVIER, S.R.S.; BARROS, I.C.L. \& SANTIAGO, A.C.P. 2012. Ferns and lycophytes in Brazil's semi-arid region. Notas Científicas/ Short Comunication. Rodriguesia, 63(2): 483-488.

ZAMUNER, A.B. 2011. Evolutive trends in Mesozoic lygnophyta from South-Western Gondwana (pteridosperms, cycadales, bennettitales) towards a synthesis. In: CARVALHO, I.S.; SRIVASTAVA, N.K.; STROHSCHOEN JR., O.\& LANA, C.C. (eds.). Paleontologia: Cenários de vida. (Ed. Interciência), Rio de Janeiro, 4: 45-56.
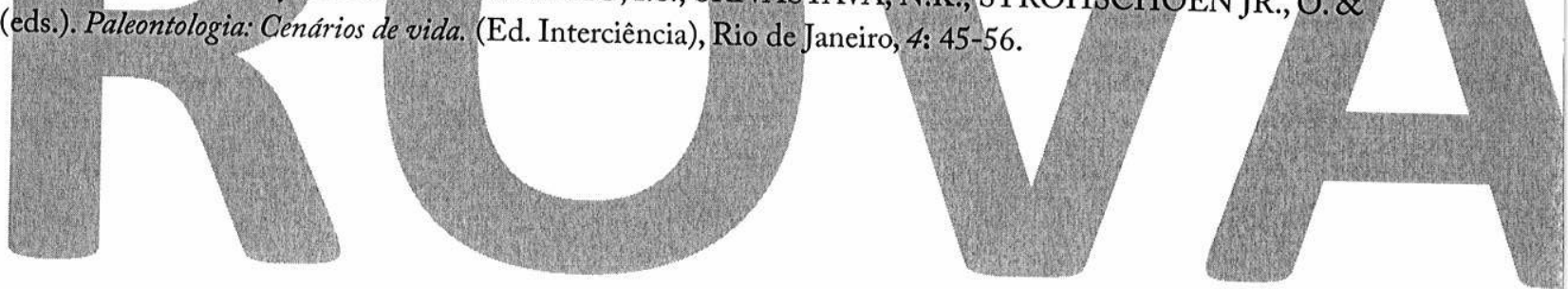
In other words, the history of any one part of the earth, like the life of a soldier, consists of long periods of boredom and short periods of terror.

Derek V. Ager, 1973 The Nature of the Stratigraphical Record 